UNIVERSIDADE DE SÃO PAULO

FACULDADE DE FILOSOFIA, LETRAS E CIÊNCIAS HUMANAS

DEPARTAMENTO DE LINGUÍSTICA

PROGRAMA DE PÓS-GRADUAÇÃO EM SEMIÓTICA E LINGUÍSTICA GERAL

\title{
O gesto em dança: descrição da gestualidade em uma narrativa dançada
}

Ana Luisa Seelaender

Dissertação apresentada ao Programa de PósGraduação em Semiótica e Linguística Geral do Departamento de Linguística da Faculdade de Filosofia, Letras e Ciências Humanas da Universidade de São Paulo para a obtenção do título de Mestre em Linguística

Orientadora: Profa. Dra. Evani de Carvalho Viotti

\section{VERSÃO CORRIGIDA}

São Paulo 
0 gesto em dança: descrição da gestualidade em uma narrativa dançada 
Dedico este projeto a meus pais, Teresa e Sergio, a quem devo minha formação intelectual e pessoal, fundamentais para realizar a vida, e por acreditarem em mim desde sempre, proporcionando a liberdade necessária para minha formação como artista. 


\section{Breve biografia}

Ana Luisa Seelaender nasceu no Rio de Janeiro, Brasil, em 1966. Em janeiro de 1981 passou a integrar o elenco do Balé da Cidade de São Paulo, onde permaneceu até janeiro de 1987. A partir de então trabalhou profissionalmente em espetáculos de dança e teatro, sob a direção, entre outros, de José Possi Neto, Márcio Aurélio, Bebeto Cidra, Fernando Lee, Susana Yamauchi, João Maurício, Naum Alves de Souza e Fernando Meirelles, tendo excursionado pela Alemanha, Áustria e Espanha. Atuou, ainda, nos programas infantis Rá-Tim-Bum e Castelo Rá-Tim-Bum, na TV Cultura, além de performances e curta-metragens. Em 2000, aliou a seus projetos de dança o ensino de inglês como língua estrangeira para adolescentes e adultos. Graduou-se em Letras, nas habilitações de Linguística e Português, pela Universidade de São Paulo, em 2009. 


\section{Agradecimentos}

A meu marido, Paolo, e meus filhos, Fernando, Renato, Marco e Mathias, agradeço a paciência que tiveram ao longo de todo o processo. Seu apoio foi fundamental para que eu pudesse realizar este trabalho.

Como um projeto de dança, este trabalho somente foi possível pelo esforço e empenho de várias pessoas. Gostaria de agradecer a todas essas pessoas que me ajudaram a realizar este projeto, começando por minha orientadora, Evani Viotti, responsável por manter meus pés no chão e minha cabeça em cima do pescoço. À sua inspirada docência devo também a escolha da área de Linguística em minha graduação, e o incentivo para unir as duas histórias de minha vida, a artística e a linguística, em meu mestrado. Agradeço ao Prof. Leland McCleary, do Departamento de Línguas Modernas, da FFLCH, sua orientação informal, que me permitiu entrar no mundo dos gestos pela porta da frente.

Agradeço imensamente a meu grande mestre Ismael Guiser, que me guiou nos caminhos da dança, me incentivando através de elogios e críticas. Mas também agradeço a meus professores Yoko Okada, Yelle Bittencourt, Yara von Lindenau, Abujamra, Umberto Silva, Marcos Verzani, Beatriz Cardoso, Liliane Benevento e Lourenço Homem, todos fundamentais em minha carreira na dança. A todos os meus companheiros de dança, mas de maneira especial à Ciça Meirelles, questionadora e incentivadora da minha pesquisa, à Susana Yamauchi, pelas incontáveis oportunidades oferecidas para meu crescimento profissional e intelectual, e à profa. Julia Ziviani, por me lembrar da importância de minha história na dança, pela leitura atenta do meu trabalho, e pelas críticas e sugestões fornecidas por ocasião de minha qualificação.

Gostaria de agradecer também à profa. Esmeralda Negrão sua leitura cuidadosa e seus comentários em meu exame de qualificação, fundamentais para a realização de um trabalho científico bem embasado. Expresso meus agradecimentos aos professores arguidores em minha banca de ingresso na pós-graduação, Esmeralda Negrão e Marcos Lopes, e ao Prof. Ronald Beline, chefe do Departamento de Linguística, por acreditarem em minha competência para a realização desta pesquisa. Agradeço também à banca examinadora para concessão da bolsa de estudos do CNPq, Profs. Olga Coelho, Antônio 
Vicente Pietroforte e Waldir Beividas, e representantes discentes, Bruna Zerbinatti e Rafael Minuzzi.

Agradeço a meu orientador do programa de Iniciação Científica, Prof.Manoel Luiz Gonçalvez Corrêa, e a meus professores da graduação pela orientação em minha formação: Evani Viotti, Ivã Lopes, Paulo Chagas, Beatriz Raposo, Ronald Beline, Margarida Petter, Marcos Lopes, Esmeralda Negrão, Ana Müller e Elaine Grolla. A meus professores na pós-graduação, agradeço a inspiração e apoio para seguir minha pesquisa: Evani Viotti, Leland McCleary, Diana Passos Luz de Barros e Norma Discini. Agradeço ao Prof. Marcelo Barra Ferreira a orientação durante o estágio do Programa de Aperfeiçoamento de Ensino.

À Profa. Irene Mittelberg, agradeço a atenção e orientação, tanto em sua estada na USP quanto em Lund, na Suécia, por ocasião do V Congresso da Sociedade Internacional de Estudos do Gesto. Agradeço aos Profs. Sherman Wilcox e David Quinto-Pozos a atenção e discussão dos dados. Agradeço ainda à Profa. Jana Bressem pela discussão de meus dados durante o VI Congresso Internacional sobre Metáfora na Linguagem e no Pensamento, em Porto Alegre, e em Lund. Meus agradecimentos ao Prof. Alan Cienki por seus comentários no encontro em Lund, e aos Profs. Tony Berber Sardinha e Vera Menezes por seus comentários durante o congresso sobre metáfora. Agradeço à profa. Drid Williams a atenção e indicação de bibliografia, e a Rosa Seelaender a leitura e revisão da língua inglesa.

A meus colegas de LLIC e parceiros de discussões Thaís Bolgheroni, Renata Moreira, Juliana Antunes, João Paulo da Silva, Joana Bartolini Franco, Fernanda Canever, Lívia Oushiro, meu agradecimento pelos ouvidos e ombros emprestados nos períodos críticos e não críticos, pelo incentivo e pelas sugestões preciosas. Agradeço também aos colegas Cacilda Vilela, João Cortese, Lígia Raquel Testa Torelli, Ivan Pasta Zanni, Aline de Palma, Alexandre Guimarães, Ana Lucia Barguil e Danilo Carlos pelas discussões e contribuições para minha vida acadêmica.

Gostaria ainda de agradecer aos secretários do departamento Érica, Róbson e Ben Hur, sempre solícitos e prestativos, ao $\mathrm{CNPq}$ pelo auxílio financeiro para a realização desta pesquisa, ao Departamento de Linguística pelo auxílio financeiro para sua divulgação em congressos nacionais e internacionais, e à Escola do Futuro, em 
especial a Claudia Martins Pires, pelo acolhimento e estabelecimento de excelente ambiente de trabalho. 


\section{Resumo}

Este trabalho tem como objetivo descrever e analisar os gestos produzidos em contexto de narrativa dançada, tomando como base os estudos dos gestos que acompanham a fala (Kendon 2004, McNeill 1992, Kita et al. 1998, Mittelberg 2006, Streeck 2009, entre outros). Para esse fim, adapto para o discurso dançado a proposta de estrutura tripartite de Poyatos (2002) para o discurso oral. Poyatos prevê os níveis linguístico (elementos segmentáveis), paralinguístico (elementos supressegmentais), e quinésico (postura e gestualidade). Os três níveis colaboram para a construção de sentido do discurso verbal. Mantenho a estrutura tripartite, propondo, para a dança, os níveis técnico (elementos segmentáveis, incluída a gestualidade convencionada pela técnica de dança), paraquinésico (elementos não-segmentáveis ligados à dinâmica do movimento), e gestual (postura e gestualidade ligada à comunicação cotidiana, incluída a pantomima). Gestos são considerados, então, quaisquer movimentos expressivos do corpo e/ou da face que não pertençam aos níveis técnico e paraquinésico. A interação entre os níveis para a construção do significado também fica mantida. Para poder verificar a pertinência da proposta, observo, entre outras, a cena do balcão e a cena final na versão de Romeu e Julieta, de William Shakespeare, coreografada por Kenneth MacMillan para o The Royal Ballet, e a cena final da versão de Rudolf Nureyev para o Ballet de L'Opéra de Paris. O programa ELAN (EUDICO Language Annotator), versão 4.1.1, desenvolvido pelo Instituto Max Planck, e largamente usado na transcrição de línguas de sinais, foi utilizado para a transcrição dos dados em diferentes trilhas. Ele possibilita descrever de maneira mais abrangente os vários aspectos simultâneos dos gestos, como o movimento das mãos, traços de expressão facial (movimento de sobrancelhas, pálpebras, olhar e boca), entre outros. O objetivo do estudo dos gestos que acompanham a dança é corroborar a proposta da relação entre gesto e conceitualização, entendendo a contribuição do elemento gestual para a construção de significado em um discurso, seja ele oralizado, sinalizado ou dançado.

PALAVRAS-CHAVE: dança, gesto, discurso, conceitualização 


\section{Abstract}

This work aims to describe and analyze gestures produced in a danced narrative, following the lines proposed in co-speech gesture studies (Kendon 2004, McNeill 1992, Kita et al. 1998, Mittelberg 2006, Streeck 2009, among others). To accomplish this goal, I adapt to the dance discourse Poyatos's proposal (2002) for verbal discourse. According to Poyatos, the verbal discourse is built upon a tripartite structure comprising a linguistic layer (with segmental elements), a paralinguistic layer (which includes suprasegmental elements) and a kinesic layer (including posture and gesture). He proposes that meaning construction in verbal discourse relies on the interaction of these three layers. My proposal is to maintain the triple structure to analyze dance discourse as well as the interaction between its specific layers: technical (which includes segmental elements of the dance technique), parakinesic (including non-segmental elements related to the dynamics of movement), and gestural (related to the posture of the body and gesture, including pantomime). Gesture will, then, be considered any expressive movement of body and/or face that is not part either of dance technique or of its dynamic elements. To verify the relevance of this proposal, I analyze a part of the balcony scene and the final one, among others, from Kenneth MacMillan's version of Romeo and Juliet, by William Shakespeare, created for and performed by The Royal Ballet, and the final scene from Rudolf Nureyev's version for the Ballet de L'Opéra de Paris. The Max Planck software, ELAN (EUDICO Language Annotator), version 4.1.1, largely used to transcribe sign languages, was used for the transcription of the data into several different tiers. This allows for a better description of the many simultaneous aspects of the gestures, such as hand movement and facial expressions features (eyebrows, eyelids, gaze and mouth movements), among others. The aim of studying gestures that accompany dance is to reinforce the proposal of correlation between gesture and conceptualization, understanding the contribution of the gestural element to meaning construction in a discourse, being it oral, signed or danced.

KEY WORDS: dance, gesture, discourse, conceptualization 


\section{Índice}

Breve biografia

Agradecimentos $\quad$ ii

Resumo

Abstract vi

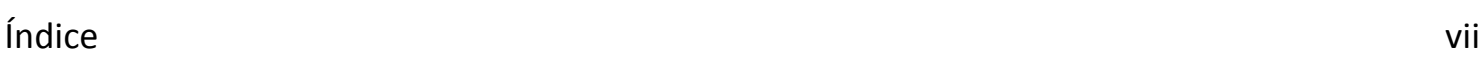

Tabelas $\quad$ ix

Figuras $\quad$ X

$\begin{array}{lr}\text { Introdução } & 1\end{array}$

Capítulo 1 Gesto em dança $\quad 8$

$\begin{array}{lr}1.2 \text { Estrutura tríplice } & 12\end{array}$

$\begin{array}{ll}\text { 1.2.1 Nível técnico } & 15\end{array}$

1.2.1.1 Histórico da dança clássica 15

1.2.1.2 Técnica clássica 19

$\begin{array}{ll}\text { 1.2.2 Nível gestual } & 36\end{array}$

1.2.2.1 Categorização de gestos que acompanham a fala 37

1.2.2.2 Uma proposta de categorização para os gestos que acompanham a dança $\quad 43$

$\begin{array}{ll}\text { 1.2.3 Nível paraquinésico } & 47\end{array}$

$\begin{array}{lll}\text { Capítulo } 2 \text { Metodologia } & 50\end{array}$

$\begin{array}{lr}2.1 \text { Materiais } & 50\end{array}$

$\begin{array}{ll}2.2 \text { Métodos } & 52\end{array}$

2.2.1 Programas de edição e de transcrição

$\begin{array}{ll}\text { 2.2.2 Transcrição } & 57\end{array}$

$\begin{array}{lll}\text { Capítulo } 3 & \text { Análise dos dados } & 79\end{array}$ 
3.2 Icônicos imagéticos 95

3.3 Icônicos diagramáticos 106

3.4 Icônicos metafóricos 119

3.5 Batidas 132

3.6 Coesivos 134

$\begin{array}{ll}\text { 3.7 Algumas considerações } & 136\end{array}$

Considerações finais 141

$\begin{array}{ll}\text { Bibliografia } & 144\end{array}$ 


\section{Tabelas}

Tabela 1 Tabela semiótica para dança em geral (Hanna 1990)

Tabela 2 Categorização de gestos que acompanham a fala (McNeill 1992, Mittelberg 2006) e gestos que acompanham o discurso dançado 


\section{Figuras}

Figura 1. Reprodução de análise baseada na estrutura tríplice de Poyatos (2002, figura 4.1) ...13

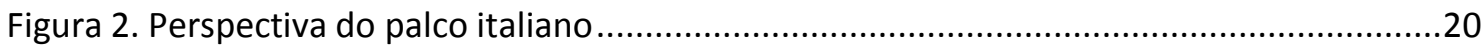

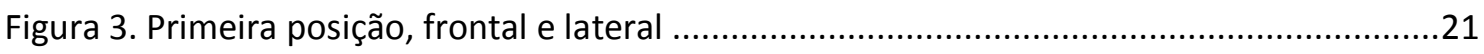

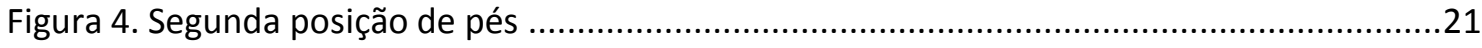

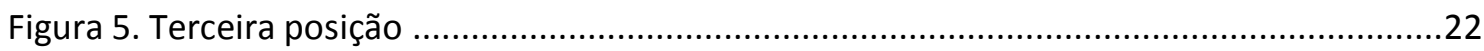

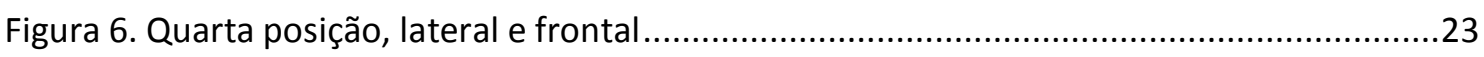

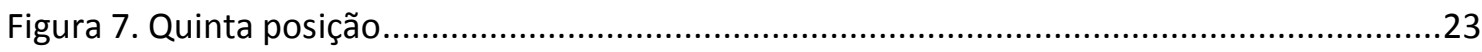

Figura 8. Primeira posição e primeira posição alta de braços ....................................................25

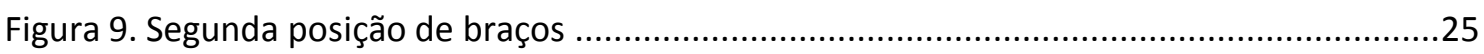

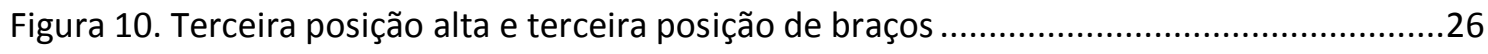

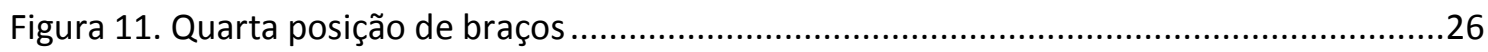

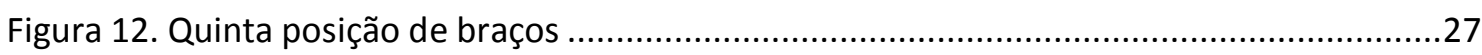

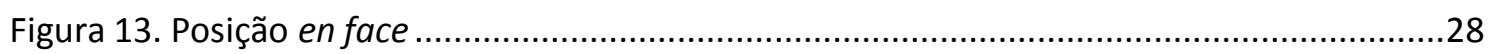

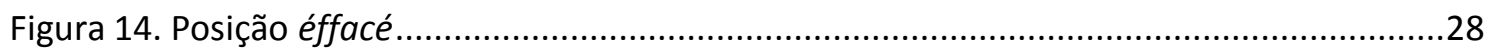

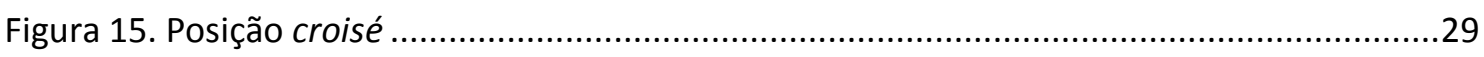

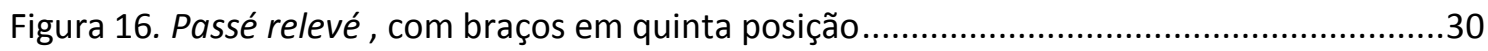

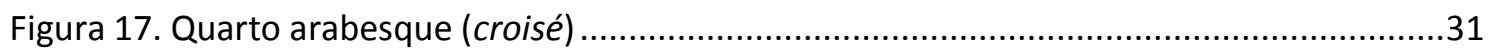

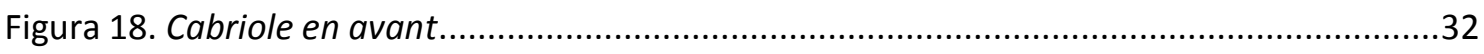

Figura 19. Alteração do ponto inicial do grand jeté, executado a partir de cou-de-pied .............33

Figura 20. Exemplo de gesto icônico, conforme McNeill (1992, p. 12) …..................................37

Figura 21. Exemplo de gesto metafórico, retirado de Mittelberg (2006, p. 246) .......................38

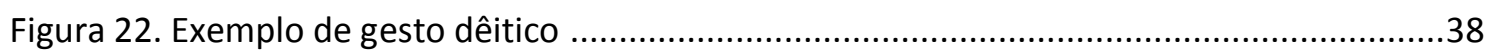

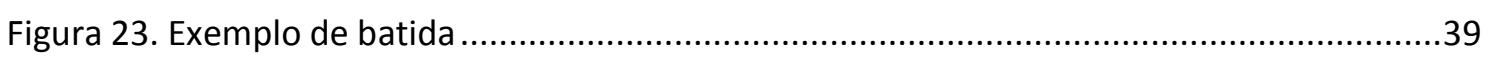

Figura 24. Exemplo de gesto coesivo, retirado de McNeill (1992, p. 17) .................................40

Figura 25. Exemplo de hipoícone imagético, retirado de Farias e Queiróz (2006, p.296)..........41

Figura 26. Exemplo de hipoícone diagramático, conforme Farias e Queiróz (2006, p. 295). .....41

Figura 27. Exemplo de hipoícone metafórico, retirado de Fariase Queiróz (2006, p. 295). .......42

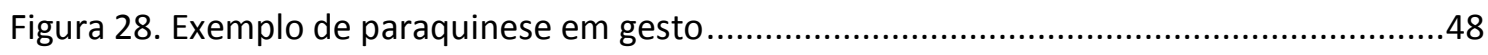

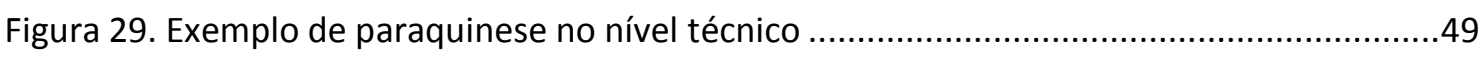

Figura 30. Janela do programa ELAN com transcrição para os dois bailarinos ............................53

Figura 31. Janela do programa ELAN com trilha UI selecionada na transcrição do bailarino .....54

Figura 32. Janela do programa ELAN com a transcrição de gesto reduzida .................................55

Figura 33. Janela do programa ELAN com a transcrição de gesto expandida..............................55

Figura 34. Janela do programa ELAN com indicação de referência de tempo pontual e

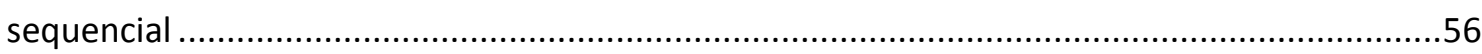

Figura 35. Janela do programa ELAN com indicação dos botões de velocidade do vídeo ...........57

Figura 36. Exemplo de trilha UI (unidade ideacional), retirado da cena final da versão inglesa 61

Figura 37. Exemplo da trilha Gesto, retirado da cena do balcão na versão inglesa.....................62

Figura 38. Exemplo das trilhas Gesto e Fases do gesto, referentes à bailarina, retirado da cena

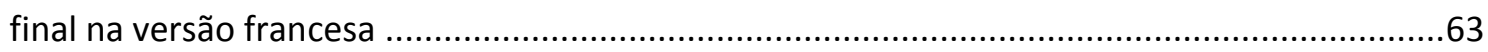

Figura 39. Exemplo da trilha mão direita, retirado da cena do balcão da versão inglesa...........64

Figura 40. Exemplo da trilha mão esquerda, retirado da cena do balcão da versão inglesa ......65 
Figura 41. Exemplo da trilha braço direito, retirado da cena final da versão inglesa

Figura 42. Exemplo da trilha braço esquerdo, retirado da cena final da versão inglesa ............67

Figura 43. Exemplo da trilha ombros, retirado da cena final na versão inglesa .........................68

Figura 44. Exemplo da trilha torso, retirado da transcrição da cena final na versão francesa ...69

Figura 45. Exemplo da trilha cabeça, retirado da transcrição da cena final na versão francesa.70

Figura 46. Exemplo da trilha sobrancelhas, retirado da transcrição da cena final na versão

inglesa

Figura 47. Exemplo da trilha pálpebras, retirado da transcrição da cena final na versão inglesa

Figura 48. Exemplo da trilha olhar, retirado da transcrição da cena do balcão na versão inglesa

Figura 49. Exemplo da trilha boca, retirado da transcrição da cena final na versão francesa ....74

Figura 50. Anotações simultâneas em trilha de mão ................................................................74

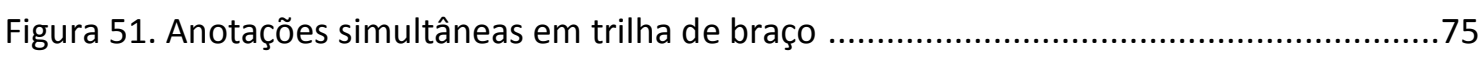

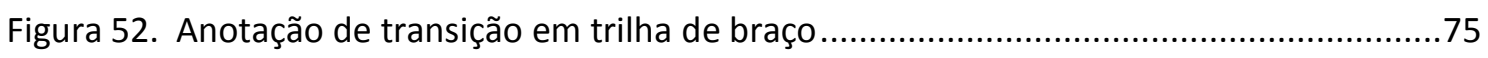

Figura 53. Gesto produzido por articuladores e diferentes fases ..............................................76

Figura 54. Diferentes gestos produzidos quase simultaneamente .............................................77

Figura 55. Diferentes gestos produzidos com fases iguais ......................................................

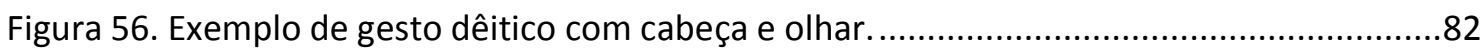

Figura 57. Exemplo de gesto dêitico com cabeça, olhar e braço (Romeu). a) posição inicial; b)

gesto realizado com a cabeça; c) volta da cabeça e continuação do braço; d) posição final.......84

Figura 58. Exemplo de gesto dêitico com cabeça e olhar (Julieta). a) posição inicial. ..................85

Figura 58. (cont.) Exemplo de gesto dêitico com cabeça e olhar (Julieta). b) posição final.........85

Figura 59. Gesto dêitico em sequência coreográfica. a) posição inicial; b) gesto dêitico feito com a cabeça, c) posição final.

Figura 60. Exemplo de gesto dêitico em sequência coreográfica. a) posição anterior; b) gesto dêitico realizado com o olhar e a cabeça; $c$ ) gesto dêitico realizado com cabriole derriére. ......88 Figura 61. Gestos dêiticos na cena final, versão inglesa. a) cabeça e olhar para diagonal direita fundo; b) cabeça e olhar para diagonal direita frente.

Figura 62. Gestos dêiticos na cena final, versão francesa. a) cabeça e olhar voltados para a lateral esquerda; b) cabeça e olhar voltados para diagonal alta. .90 Figura 62. (cont.) Gestos dêiticos na cena final, versão francesa. c) cabeça e olhar para o alto e para frente; d) cabeça e olhar para o alto e para a lateral. . .91 Figura 63. Gesto dêitico no encontro do corpo de Romeu, na versão inglesa. a) cabeça e olhar voltados para a lateral esquerda; b) cabeça e olhar voltados para a diagonal frente baixa.......92 Figura 64. Gesto dêitico no encontro do corpo de Romeu, na versão francesa. a) cabeça e olhar voltados para a diagonal direita; b) cabeça e olhar voltados para baixo; c) cabeça e olhar voltados para diagonal fundo esquerda.

Figura 64. (cont.) Gesto dêitico no encontro do corpo de Romeu, na versão francesa. d) corpo se volta para acompanhar a direção da cabeça e do olhar.

Figura 65. Exemplo de gesto icônico imagético na cena do balcão. a) ponto inicial do gesto; b) ponto medial; c) ponto final, com projeção do tronco e da cabeça para frente.

Figura 66. Exemplo de gestos icônicos imagéticos retirados da cena do balcão na versão inglesa. a)posição do gesto anterior; b) início do movimento de rotação do corpo; c) final do movimento com o corpo, com movimento de braço; d) posição final. 
Figura 67. Exemplos de gestos icônicos imagéticos retirados da cena do balcão. a)posição inicial; b)início do gesto de braços; c) posição final do gesto de braços; d)início do gesto corporal; e) posição intermediária do corpo; f) posição final do corpo.

Figura 68. Exemplo de gesto icônico imagético retirado da cena do balcão. a) posição inicial com flexão do cotovelo para trás; b) posição final do braço e da mão direita..........................100

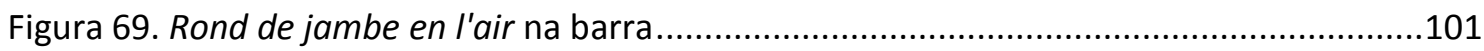

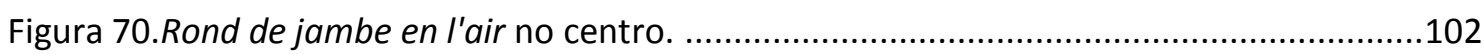

Figura 71. Exemplo de gesto icônico imagético. a) gesto conjugado com rond de jambe en l'air

e enveloppé. b) gesto conjugado com arabesque.

Figura 72. Abraço com gesto icônico imagético, retirado da cena final na versão francesa. a) posição inicial; b) suporte do corpo com as duas mãos nas costas; c) suporte do corpo com uma mão nas costas e a outra na cabeça.

Figura 73. Exemplo de gesto icônico diagramático, produzido tanto por Romeu quanto por Julieta. a) preparação do gesto; b) posição final do gesto.

Figura 74. Exemplo de uso canônico dos braços ao final de uma pirueta passé. .......................108

Figura 75. Exemplo de gesto utilizado cotidianamente para chamar alguém 109

Figura 76. Exemplo de gesto icônico diagramático (cena do balcão). a) pirueta passé; b) início do gesto; c) posição final da pirueta e do gesto. 110

Figura 77. Exemplo de gesto icônico diagramático (cena do balcão). a) pirueta attitude; b) posição intermediária; c) início do gesto em quarta posição allongé croisé; d) posição final. .111 Figura 78. Exemplos de gesto de convite para dançar, retirados da cena do baile na versão inglesa. a) e b) palma da mão inclinada para cima; c) e d)palma da mão para baixo.

Figura 79. Exemplo de gesto icônico diagramático (cena do balcão). Julieta abraçando o braço de Romeu e segurando sua mão.

Figura 80. Exemplo de gesto icônico diagramático (cena do balcão). Julieta segurando uma mão com a outra.

Figura 81. Abraço com gesto diagramático, retirado da cena final na versão inglesa..............116

Figura 82. Exemplo de gesto icônico diagramático (cena final).

Figura 83. Exemplo de gesto icônico diagramático, retirado da cena final na versão francesa.

Figura 84. Exemplos de grand jeté. a) com braços em terceira posição; b) em arabesque......119

Figura 85. Exemplo de gesto metafórico com grand jeté.....................................................120

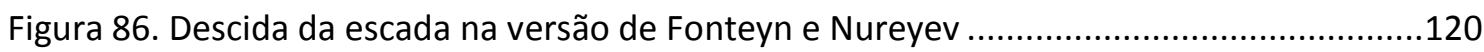

Figura 87. Exemplo de recorrência de gesto icônico metafórico com arabesque. ....................121

Figura 88. Exemplo de gesto icônico metafórico em final de pirueta passé (cena do balcão) .123

Figura 89. Grand rond de jambe en l'air realizado com o apoio da barra.

Figura 90. Exemplo de gestos icônicos metafóricos (cena do balcão), baseados na metáfora orientacional ALEGRIA É PARA CIMA (perna direita e cabeça) e na metáfora ontológica EMOÇÃO É OBJETO (braços e mãos).

Figura 91. Exemplo de gesto icônico metafórico (cena final), realizado com os braços...........126

Figura 92. Gesto icônico metafórico retirado da cena final na versão inglesa, realizado com a cabeça, face e ombros.

Figura 93. Gesto icônico metafórico retirado da cena final na versão francesa, realizado com a cabeça, face, corpo e mãos. 
Figura 94. Exemplo de gesto icônico metafórico retirado da cena final na versão francesa,

realizado com o torso, a cabeça, os braços e a face

Figura 95. Cambré com braços em terceira posição de braços.

Figura 96. Sequência retirada da cena final na versão francesa, na qual Julieta realiza um gesto icônico diagramático

Figura 97. Exemplo de gesto icônico metafórico retirado da cena final na versão francesa....131

Figura 98. Exemplo de batida na cena do balcão, realizada através da elevação da parte superior do tronco.

Figura 99. Exemplo de batida na cena final, realizado com o movimento do corpo para frente e para trás.

Figura 100. Exemplo de gesto coesivo de Julieta. a)primeira ocorrência; b) segunda ocorrência do gesto de braços.

Figura 101. Exemplo de gesto coesivo de Romeu. a) primeira ocorrência; b) segunda ocorrência

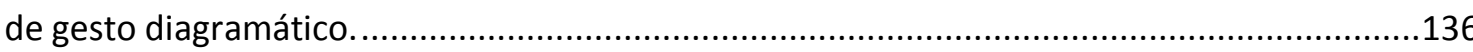

Figura 102. Composição de gesto icônico diagramático com gesto icônico metafórico. .........138

Figura 103. Composição de gesto icônico imagético com gesto icônico metafórico.................139

Figura 104. Exemplos de arabesques, retirados das figuras 87 e 90 .....................................142 


\section{Introdução}

O objetivo deste trabalho é descrever a gestualidade presente em uma narrativa dançada. O termo narrativa deve ser entendido como proposto por Labov e Waletsky (1967): uma recapitulação de eventos passados, guardada a ordem de suas ocorrências (p.20). Segundo McNeill (1992), narrativas incluem ainda múltiplos níveis, com mudanças de tempo, espaço, perspectiva, distância entre narrador e narração. As coreografias analisadas neste trabalho seguem uma estrutura semelhante à das narrativas.

Para realizar meu objetivo, tomo de empréstimo à literatura dos gestos que acompanham a fala (também chamados de gestos coverbais) a definição proposta por Kendon (2004), na qual gestos não são apenas movimentos realizados com as mãos, mas também aqueles realizados com o corpo e os membros, além de expressões faciais, que se tornam uma atividade visível que contribui para a construção de significado em um enunciado (p. 110).

De maneira geral, a literatura sobre dança tende a tratar o discurso dançado como um todo gestual, sem buscar isolar, de um lado, o movimento técnico estrutural, e de outro, o gesto de apreensão gestáltica. Para poder discretizar o que estou considerando gesto em um sistema semiótico gestual, proponho uma aproximação da estrutura do discurso dançado com a proposta da Poyatos (2002) para o discurso verbal. De acordo com essa proposta, o discurso verbal está apoiado em uma estrutura tríplice, composta pelos seguintes níveis: i) linguístico (segmental); ii) paralinguístico (suprassegmental); e iii) quinésico (postura e gestualidade). Os três níveis interagem, compondo o discurso verbal. No discurso dançado proponho os seguintes níveis, que se integram para a construção do significado: $i$ ) técnico (segmental); ii) paraquinésico (suprasegmental); e iii) gestual (postura e gestualidade) ${ }^{1}$. Aplico essa proposta para a dança a partir da observação de duas versões da peça Romeu e Julieta, de William Shakespeare, uma criada por Kenneth MacMillan para o The Royal Ballet, e outra coreografada por Rudolf Nureyev para o Ballet de L’Opéra de Paris, ambas apoiadas sobre a técnica de balé clássico. Dois trechos das obras foram selecionados: a cena do

\footnotetext{
${ }^{1}$ A discretização aqui sugerida deve ser entendida como uma ferramenta meramente metodológica. Técnica e gesto devem ser tomados como dois pólos de um contínuo.
} 
balcão, na versão de MacMillan, e a cena final do último ato, nas duas versões ${ }^{2}$. A transcrição dos gestos presentes nos trechos selecionados foi feita por meio do uso do software ELAN (EUDICO Language Annotator), versão 4.1.1, desenvolvido pelo Instituto Max Planck de Psicolinguística e disponibilizado através do sítio www.latmpi.eu/tools/elan/.

A propósito de gestos coverbais, Bressem (2008, p.1) comenta que sua caracterização é um empreendimento árduo e complicado, ainda que fala e gesto sejam expressos por meios diferentes (auditivo e visual, respectivamente). A tarefa de caracterização dos gestos que acompanham movimentos de dança mostra-se ainda mais delicada, na medida em que os meios de expressão de dança e gesto são os mesmos, como nas línguas sinalizadas. Assim, tomei como ponto de partida algumas premissas para a transcrição dos dados estabelecidas por pesquisadores que investigam a comunicação linguística face-a-face. Primeiramente, o discurso dançado foi dividido em unidades que podem se equiparar às unidades ideacionais (UI) propostas por Chafe 1980a (p.40) ${ }^{3}$. Isso significa que busquei agrupar as frases coreográficas em unidades maiores tomando por base a coesão ideacional entre elas ${ }^{4}$. A partir daí, observei e descrevi os gestos presentes nas UI, segundo a proposta de transcrição de McCleary e Viotti (2007), avançada por Leite (2008) e revista em McCleary, Viotti e Leite (2010), para línguas sinalizadas, em trilhas separadas para as mãos, braços, ombros, torso, cabeça, sobrancelhas, pálpebras, direção de olhar e boca ${ }^{5}$.

Para a análise dos gestos, parti dos estudos de gesto que acompanham a fala, na medida em que eles aprofundam o entendimento da relação entre duas modalidades de expressão diferentes para a construção do significado. A partir dos trabalhos de Adam Kendon e David McNeill foram estabelecidos vários dos critérios utilizados para o estudo dos gestos que acompanham a fala ${ }^{6}$. Kendon, (1972), propõe que a gesticulação, movimentos de mãos e braços realizados durante a interação, e a fala apresentam um

\footnotetext{
${ }^{2}$ A seleção das cenas encontra-se detalhada no capítulo 3 (pg. 80).

${ }^{3}$ Unidade ideacional é um conjunto de informação que corresponde a um mesmo foco de consciência. Esse conjunto é limitado por nossa capacidade de processamento.

4 Frase coreográfica é entendida, neste trabalho, como o encadeamento temporal dos elementos segmentáveis que constituem a técnica de dança.

${ }^{5}$ Dados certos aspectos pertinentes à linguagem da dança, foram necessárias algumas adaptações do sistema utilizado.

${ }^{6}$ Esses trabalhos tomam por base os estudos pioneiros da gestualidade realizados por Efron (1941) e Eckman e Friesen (1969).
} 
paralelismo de organização. Dessa forma, gesticulação e fala são entendidos como duas formas simultâneas de discurso, expressas através dos órgãos vocais e dos movimentos corporais. Kendon (1980) estabelece a frase gesticular, que atualmente é conhecida por frase gestual, caracterizada pela existência de um pico de esforço, atualmente golpe. Esse pico pode ser tanto precedido por uma preparação, em que o membro dirige-se ao ponto onde realizará o pico do esforço, quanto sucedido por uma retração, na qual o membro que realizou o movimento retorna à posição de descanso ou se prepara para uma nova frase. Podem, ainda, ocorrer suspensões anteriores ou posteriores ao pico, com a manutenção da configuração do membro por um espaço de tempo. Nesse trabalho, Kendon já apontava para a questão da assimetria entre as duas mãos, fator complicador no processo de descrição, pois há gestos realizados com as mãos em configuração simétrica, como quando reproduzimos o ato de segurar uma caixa, e gestos que apresentam as mãos de maneira diferenciada, como quando mantemos uma mão no gesto de segurar uma caixa e com a outra gesticulamos a ação de pegar um objeto e colocar dentro da caixa.

A partir desses conceitos e das relações entre a fala e o gesto observadas ao longo de anos de pesquisa, McNeill (1992) lançou uma teoria que propõe que o gesto, juntamente com a fala, é parte de um único sistema conceitual para a elaboração e exposição do pensamento. Sendo assim, gesto vai além de mera contraparte imagística da fala. Provocadora na época, essa teoria ainda hoje se mantém controversa justamente porque pressupõe um entendimento ampliado de língua, que integra nela as imagens criadas pelo movimento de mãos e braços. Para McNeill, como gesto e língua são um mesmo sistema, certas propriedades da fala podem ser reveladas pelos gestos.

A forma dos gestos não é fixa, mas acaba sendo o modo de análise escolhido por McNeill para classificá-los. Diferentemente, Streeck (2009), em estudos de gestos que acompanham a fala, e Humphrey (1959), referindo-se a gestos presentes em composição coreográfica, por exemplo, são autores que partem da funcionalidade do gesto para propor uma classificação. De toda forma, a categorização é feita por semelhanças de família, conceito tomado a Wittgenstein. No caso deste trabalho, faço a minha proposta de classificação dos gestos que acompanham a dança a partir das categorias estabelecidas por McNeill (1992) - gestos dêiticos, icônicos, metafóricos, coesivos e batidas -, incorporando o conceito do hipoícone peirceano na categorização gestual, como sugerido por Mittelberg $(2006,2008)$. De acordo com a teoria de Peirce, os signos 
dividem-se em três categorias: ícones, índices e símbolos. Um ícone se instancia por meio de hipoícones, que podem ser imagéticos, diagramáticos ou metafóricos. O ícone imagético e o ícone metafórico correspondem, grosso modo, à caracterização dada por McNeill para os gestos icônicos e metafóricos, respectivamente. O ícone diagramático incorpora uma conceitualização que se assenta sobre um processo metonímico e não encontra correspondência na tipologia de McNeill.

A classificação dos gestos proposta por McNeill (1992) tem um caráter formal, como já mencionado. Ela inclui os gestos: i) dêiticos - gestos de apontamento; ii) icônicos - gestos que representam conceitos ou objetos concretos; iii) metafóricos gestos que representam conceitos ou objetos abstratos; iv) batidas - gestos que acompanham o ritmo da fala; e $v$ ) coesivos - gestos que retomam o tópico discursivo separado temporalmente por uma digressão. Essa classificação é retomada mais detalhadamente no próximo capítulo ${ }^{7}$.

McNeill estabelece, ainda, a distinção entre gesticulação, pantomimas e emblemas. A gesticulação refere-se aos movimentos realizados pelas mãos e pelos braços que acontecem quando falamos com os outros, como o gesto de desenhar o contorno externo de um vaso quando nos referimos a ele no discurso. A pantomima é a representação de uma ação, como quando reproduzimos um andar claudicante. E o emblema é um gesto convencionalizado dentro de um grupo cultural, reconhecível, portanto, para os membros do grupo, sendo um exemplo clássico o gesto de $\mathrm{OK}$ produzido por norte-americanos para indicar que tudo está bem. Para alemães e brasileiros, a mesma configuração gestual tem uma interpretação bastante diversa e vulgar, considerada ofensiva.

Para McNeill, a gesticulação ocorre quase sempre em presença de fala, a pantomima pode ou não acompanhar a fala, e os emblemas são produzidos em ausência

\footnotetext{
${ }^{7}$ Há, ainda, gestos que ilustram o discurso, veiculando o mesmo conteúdo expresso pela fala, atuando como um reforço, e gestos que contribuem com informação adicional. Por exemplo, quando o falante diz: "Daí ele saiu do tubo", ao mesmo tempo em que realiza um movimento com o corpo semelhante a rastejar-se pelo tubo, ocorre uma complementaridade do gesto com relação ao discurso, já que o verbo sair não expressa o modo como uma ação se dá. Pode acontecer, também, de um gesto exprimir conteúdo contraditório em relação à fala, como no caso de uma pessoa expressar um sentido ascendente na fala e fazer um gesto em sentido descendente. Quando há contradição entre fala e gesto, a tendência é corrigir o discurso, e não o gesto, pois a ideia a ser veiculada foi expressa corretamente através do gesto. Foi essa diversidade de possibilidades e a ampliação do conceito de gesto, incluindo o movimento de outras partes do corpo, que despertou meu interesse pela área de gestos.
} 
de fala, formando um contínuo que vai da presença à ausência de discurso. McCleary e Viotti $(2010,2011)$ questionam esse contínuo para as línguas sinalizadas, já que McNeill as coloca, nesse contínuo, em oposição à gesticulação, à pantomima e ao emblema, restringindo-a apenas a elementos linguísticos. Como qualquer língua natural oral, as línguas sinalizadas também são compostas por gestos, pantomimas e emblemas, ainda que elementos linguísticos e elementos gestuais sejam produzidos através do mesmo meio, o corporal. Assim, o contínuo proposto não se aplica. Mesmo em língua oral, temos a ocorrência de emblemas junto com a fala, como quando dizemos que tudo está bem fazendo, simultaneamente, o gesto de mão fechado com o polegar para cima. Em dança, na qual o corpo serve de meio para a execução do movimento técnico e do movimento gestual, as três categorias estão presentes em ausência de fala.

Neste trabalho, o conceito de gesto é bastante expandido em relação àquele utilizado por McNeill. As categorias de gestualidade e pantomima têm, na dança clássica, uma relação diferente daquela proposta para o acompanhamento da fala. A pantomima que acompanha a fala é uma opção para a narrativa, ao passo que, nas narrativas dançadas, a pantomima e o gesto têm um estatuto fundamental, pois a técnica tem um caráter demasiadamente abstrato para sustentar a narrativa.

Trabalhos atuais sobre gestos que acompanham a fala (Cienki e Müller 2008, Calbris 2008, Kita 2003, Evola 2010, entre outros) têm como base os princípios estabelecidos por Kendon e McNeill. Eles expandem os critérios morfológicos e semânticos para o estudo dos gestos, integrando conceitos da área cognitiva, linguística e etnográfica, e criando uma rede de relações que possibilita o entendimento da construção do significado como um processo integrado de vários sistemas semióticos. A importância do gesto na composição do significado tem sido demonstrada em trabalhos como os de Goodwin (2000, 2003), LeBaron \& Streeck(2000), Williams (2008), entre outros. Eles ressaltam a relação entre gesto, língua e ambiente envolvida no próprio processo de pensamento, inclusive através da manipulação de objetos (Hutchins 2006, Streeck 2009). Susan Goldin-Meadow (1993) acompanha McNeill (1992, 2000, 2005) na proposta da gesticulação como uma forma de pensamento, em relação direta com processos cognitivos, no período de aquisição de língua pelas crianças. A observação da gestualidade em contexto não linguístico visa a contribuir para o entendimento da relação entre gesto e cognição, reforçando dados encontrados em contexto linguístico ou abrindo novas perspectivas para os trabalhos que tratam da relação entre gesto e fala. 
Com relação ao gesto na dança, quando as máscaras foram descartadas (entre 1665 e 1670), a mímica se tornou um elemento essencial para a narrativa. As mãos chamavam a atenção do público, assim como a caracterização fisionômica. Havia, no entanto, um decoro gestual, definido por consideração social e estética, ou seja, uma gestualidade apropriada para a pantomima, para o palco, mas não para outras situações envolvendo a oratória. Esse decoro gerava uma imobilidade no repertório de gestos. Contra essa imobilidade, entre outros aspectos, articulou-se um movimento, em meados do século XVIII, no sentido de naturalizar a interpretação. Jean-Georges Noverre, em cartas publicadas em 1760, criticou o uso excessivo da técnica e o enrijecimento da gestualidade. Ele denunciou a incompatibilidade do sistema de notação inventado por Pierre Beauchamps (trazido a público pela primeira vez em 1700 por Raoul-Anger Feuillet) com os avanços da técnica e a gestualidade expressiva do balé de estrutura narrativa (Pappacena 2009, p. 131). Influenciado pelo tratado de John Weaver, Anatomical and Mechanical Lectures upon Dancing (Londres, 1721), pela técnica de interpretação do ator britânico David Garrick e pela Commedia Dell'Arte italiana, ele fez experiências com gestos em caracterizações dramáticas, desenvolvendo um estilo em que o gesto era empregado junto a uma técnica desprovida da redundância e do virtuosismo remanescentes do estilo da Opéra. Para Noverre, os gestos eram o resultado de sentimentos, tornando-se intérpretes confiáveis de cada espírito que os utilizava (Cohen 1974, p. 58).

No início do século XIX, um novo movimento veio privilegiar novamente a técnica, dando a ela um lugar de destaque, inclusive para a expressão de sentimentos e emoções. Até o começo do século $\mathrm{XX}$, os bailarinos profissionais seguiam regras estritas de comportamento e de gestualidade adequadas aos teatros de corte e às plateias aristocráticas. Nesse período, o russo Mikhael Fokine transformou a dança clássica, eliminando as regras e os gestos convencionais, reintroduzindo uma naturalidade ligada aos usos e costumes do povo (Lawson 1979, p. 7). É a partir dessa ligação com o uso cotidiano da gestualidade que a observação da gestualidade é feita neste trabalho.

O primeiro capítulo começa tratando do gesto em dança a partir da perspectiva da literatura de dança ${ }^{8}$. Na sequência, apresento a proposta de Poyatos (2002), mencionada acima, e minha adaptação dessa proposta para o discurso dançado. Ao

\footnotetext{
${ }^{8}$ Será também tratada a contribuição do trabalho de Trotta (2004), feita a partir da perspectiva da semiótica greimasiana,.
} 
detalhar os níveis propostos, um resumo da história da dança clássica se faz necessário, bem como uma breve apresentação da técnica clássica, que é a base das duas versões observadas. No segundo capítulo, trago o percurso metodológico do trabalho, comentando aspectos artísticos das duas versões que podem, de alguma forma, influenciar a análise dos dados. Nesse capítulo trato também da transcrição dos dados, apresentando de maneira mais detalhada o programa ELAN mencionado acima. O terceiro capítulo é o de análise dos dados, com base nos pressupostos apresentados nos capítulos precedentes. Encerro esse capítulo discutindo aspectos que emergiram na análise. Apresento, então, as considerações finais deste trabalho. 


\section{Capítulo 1 Gesto em dança}

A dança faz parte da história do homem como elemento de rituais, extensivamente estudado pela antropologia e etnografia (Kaeppler 1972, Hanna 1979, 1983, Williams 1977, 1991, Farnell 1994, entre outros), e como elemento de processos de seleção sexual humana, que toma por base a simetria segundo proposta de Brown et al. $(2005)^{9}$. Há, no entanto, uma distinção entre a dança que é apenas o acompanhamento de uma cadência musical (seja de caráter social ou cultural) e aquela que é uma imitação das ações e paixões humanas, e que se denomina balé, como apontado por Claude Ménestrier em tratado publicado em $1682^{10}$. Este trabalho tem o objetivo de observar a gestualidade presente nesse tipo de dança teatral ${ }^{11}$.

Como já dito, a definição de gesto que acompanha a dança é dificultada pelo fato de a execução da dança e a do gesto se darem através da mesma modalidade de ação corporal, diferentemente do que acontece com o gesto que acompanha a fala, que usa uma modalidade visual para um e uma modalidade auditiva para a outra. O empréstimo do conceito de gesto aos estudos de gesto que acompanham a fala, feito neste trabalho, deve-se ao fato de a literatura sobre dança definir gesto de maneira vaga. De acordo

\footnotetext{
${ }^{9}$ Brown et al (2005) sugerem que a simetria corporal demonstrada através da dança se torna um fator indicativo de melhor parceiro. Estudo feito com jovens jamaicanos, para quem a dança tem um papel importante para ambos os sexos, mostrou que homens mais simétricos valorizam a simetria na dança de mulheres, assim como as mulheres se mostraram mais críticas do que homens em relação à simetria na dança realizada por homens. O conceito de simetria está relacionado ao grau de assimetria flutuante, que é inversamente proporcional ao grau de estabilidade de desenvolvimento. Isso significa que um maior grau de assimetria indica uma maior taxa de morbidade, mortalidade, baixa fecundidade e outras variáveis ligadas à seleção natural e sexual (p. 1). Por outro lado, um menor grau de assimetria flutuante, presente em sujeitos tidos como simétricos, passa a indicar um parceiro (ou parceira) mais apto para a estabilidade da espécie, através de taxas menores de morbidade, mortalidade, alta fecundidade, etc.. A captura das danças através de Motion Capture isolou os movimentos de dança de todos os outros aspectos visuais, de forma a que não houvesse identificação do sexo do dançarino por parte do avaliador.

${ }^{10}$ Balé vem do francês ballet, que por sua vez tem origem em ballo, do italiano, que significa baile. Em português, adotamos a grafia balé, que será usada ao longo deste trabalho. A terminologia do balé, no entanto, é mantida em francês. Devido ao fato de a França ter se tornado um centro de excelência e referência, a solução encontrada para facilitar a comunicação entre bailarinos de diferentes origens foi a unificação do vocabulário de passos através do francês, criando no plano verbal a unidade criada pela expressão dos corpos dos bailarinos.

${ }^{11}$ É considerada dança teatral toda dança apresentada em um teatro, convencional ou não, no qual a plateia se encontra distanciada do intérprete e tem participação limitada, independentemente da técnica utilizada (clássica, moderna ou contemporânea). Esse tipo de dança se opõe tanto à dança social (terapêutica, étnica ou popular), tida como interação primária, quanto à aquisição de habilidade, através de instrução individual, participação em aulas e/ou de observação informal (Hanna 1987 [1979]).
} 
com Noland (2009), teóricos de dança, em geral, distinguem gesto pelo movimento de membros, incluída a cabeça, por oposição à postura estática ou à ambulação, que é a travessia do espaço. Noland, no entanto, define gestos como códigos de movimento expressivo que associam um movimento particular a um significado particular, de maneira que se tornem legíveis, em um modo consistente, para quem os vê (pg.xvii). Essa acepção de gesto, no entanto, dificulta a distinção entre gestos inscritos na técnica de dança, daqueles que não pertencem à técnica. Laban (1975) propõe que gestos sejam ações das extremidades, mas que não incluam nem transferência nem suporte de peso (p.60), sem, no entanto, definir as ações a que se refere com relação aos movimentos estabelecidos como técnica no balé clássico ${ }^{12}$.

Doris Humphrey, bailarina e coreógrafa de dança moderna, considera gestos como padrões de movimento estabelecidos pelo uso entre membros de uma sociedade, e reconhecíveis como gestos (1959, p.114). Essa acepção de gesto, no entanto, não abarca a gestualidade que faz parte da técnica, ou seja, a gestualidade estabelecida como parte necessária para a execução e o reconhecimento de um determinado passo. Humphrey estabelece quatro categorias para os gestos, que são, para ela, um ramo da motivação. A motivação é entendida por Humphrey como o impulso para realização de um movimento baseado em necessidade fisiológica ou intelectual, e que vem a ser peça fundamental não apenas no exercício da dança, mas também no mundo físico em geral. As categorias estabelecidas por ela estão baseadas em padrões cristalizados de movimento que emergem da ação cotidiana das pessoas. Alguns desses padrões são tão estilizados e distantes de sua origem, que há a necessidade de um trabalho mental para ser possível reestabelecer a conexão com o movimento original. Ela prevê, então, i) gestos sociais, oriundos de eventos sociais e que comunicam seu significado

\footnotetext{
${ }^{12}$ Rudolf Laban (1879 - 1958) foi um importante teórico do estudo do movimento, educador e idealizador de uma Teoria do Movimento; da Corêutica (Espaço Harmônico); do método Labanotation para anotação de dança; do Tanztheater (que teve, no século XX e início do século XXI, Pina Bausch como expoente máximo), entre outras contribuições para a epistemologia da dança. Ele propõe que os movimentos corporais sejam estudados nas seguintes dimensões: espaço, tempo, peso e fluência. Para o espaço, ficam estabelecidos os seguintes aspectos: direções (frente, trás, esquerda, direita), planos (alto, médio, baixo), extensões (perto-normal-longe, pequena-normal-grande) e caminho (direto, angular, curvo). O tempo deve ser dividido em velocidade (rápida, normal, lenta), unidades de tempo, e tempo relativo às sequências de movimento (presto, moderato, lento). O peso é dependente da energia ou força muscular usada na resistência ao peso (forte, normal, fraca) e acento, ou graus de tensão, (ênfase ou neutro, de tensão a relaxamento). A fluência, de acordo com Laban, deve ser analisada nos aspectos de fluxo (ida, interrupção, parada), ação (contínua, descontínua, parada), controle (normal, intermitente, completo) e corpo (movimento, série de posições, estaticidade).
} 
instantaneamente, como a reverência, o aperto de mão, o aceno de adeus, o abraço, entre outros; ii) gestos funcionais, que se desenvolveram a partir de ações práticas, que incluem, por exemplo, pentear os cabelos, cortar madeira, dormir, vestir-se e correr com um objetivo; iii) gestos rituais, que são não apenas movimentos relacionados a eventos religiosos, mas também a situações altamente ritualizadas, como o procedimento em uma corte jurídica, em sessões de nomeação política, na posse de um ministro de Estado, etc.; e $i v)$ gestos emocionais, utilizados para a expressão de sentimentos e emoções. Segundo Humphrey, esses gestos não possuem um padrão, pois, segundo ela, a emoção não tem forma. No entanto, alguns padrões encontram-se associados a estados emocionais como, por exemplo, no luto. Nesse caso, o padrão se caracteriza pelo corpo côncavo, braços presos ao redor do torso, as mãos cobrindo a face e os olhos quando há choro, movimento de balanço lateral ou sagital do torso, soluços e alterações no ritmo respiratório, em um padrão ligado a reações fisiológicas intensas. Humphrey propõe, ainda, que o prolongamento temporal e espacial do gesto e a distorção, com aumento, diminuição ou alteração do percurso do gesto, sejam os processos essenciais envolvidos na transformação da mímica, ou gesto natural, em movimento.

A categorização proposta por Humphrey não leva em conta diferenças nos gestos funcionais, como, por exemplo, em um beijo efetivo e em um quase beijo, que usam estratégias diferentes para sua interpretação. Gestos sociais e rituais acabam tendo muita intersecção, assim como os gestos emocionais. Uma caracterização apenas funcional carece de elementos que permitam entender os processos cognitivos subjacentes tanto à produção quanto à recepção dos gestos. Por exemplo, diferentes posições de corpo podem evidenciar diferentes focos, revelando diferentes conceitualizações de um evento, ainda que sejam gestos com a mesma função, como em um abraço. Se uma bailarina abraça o corpo inerte do bailarino, ela pode fazê-lo com uma postura de corpo voltada para cima ou voltada para baixo. A diferença na posição do corpo levará a uma diferença na interpretação desse abraço. Assim, traços formais serão distintivos de significado, e, no caso deste trabalho, são pertinentes para a análise, inclusive para a constituição do que é considerado gesto em relação ao que é considerado movimento técnico.

Kirstein (1970) entende o gesto como a ponte necessária entre as partes dançadas e a explicação narrativa da dança (p.20). Ao comentar a evolução histórica da dança clássica, Kirstein estabelece a inclusão do gesto no momento em que o balé de 
corte deixa de ser um interlúdio para tornar-se uma arte independente. O corpo já tinha sido valorizado pelos princípios da retórica clássica, recuperada no final da Idade Média. Na Antiguidade, Quintiliano ressaltava a supremacia do olhar sobre a audição, e Cícero apontava para a eloquência do corpo, mais efetiva do que palavras. Essa valorização ganhou vulto no Renascimento, quando o olhar artístico voltou-se para a beleza do corpo, agregando ao fazer artístico os conhecimentos sobre a anatomia humana que o fazer científico vinha investigando. Na evolução da dança clássica, os gestos sofreram grande influência da pantomima, que não era considerada nem diálogo, nem gesto convencional, mas sim uma sequência rítmica e harmoniosa de atitudes tomadas aos modelos naturais e clássicos. As pantomimas eram realizadas sem a posição de pés e pernas viradas para fora e apresentavam uma plasticidade e caracterização completamente distintas do virtuosismo técnico acadêmico. Kirstein ressalta que, atualmente, não há mais relação viva e necessária entre a tradição mímica e a dança acadêmica contemporânea. No entanto, a mímica no balé não pode ser considerada como um elemento à parte, tendo se tornado uma extensão do movimento técnico (Kirstein 1970, pp.20-27). A acepção de Kirstein de gesto e mímica em dança não explicita como acontece a integração desses elementos ao movimento técnico, tampouco esclarece os tipos de gesto presentes na mímica que atuam para a construção de significado em uma narrativa dançada.

No Brasil, o trabalho de Trotta (2004) toma por referência a proposição greimasiana para a gestualidade. Greimas (1967) estabelece a seguinte divisão: $i$ ) práxis gestual, ligada à intencionalidade do projeto gestual a ser realizado, sem fins comunicativos, e ii) comunicação gestual, que pressupõe a intenção de comunicação de um sujeito a outro. A práxis gestual, por sua vez, encontra-se subdividida em: $i$ ) prática, ligada ao fazer, e ii) mítica, ligada ao querer fazer. A distinção aqui não se faz a partir do plano de expressão, que poderá ser o mesmo tanto na gestualidade prática como na mítica, mas sim na diferente significação que será dada a partir do contexto enunciativo. Por se tratar de um código artificial, e incluir uma gestualidade artificial, a dança como um todo é classificada por Greimas como pertencente à gestualidade estética, tendo passado pelos processos de dessemantização (diminuição da carga semântica) e ressemantização (aumento da carga semântica), dando uma dimensão significativa à práxis gestual. Esta proposta, no entanto, não diferencia gestualidade convencionalizada 
pela técnica de dança da gestualidade ligada à expressão de emoção, assim como não contempla os diferentes aspectos da dinâmica dos gestos.

As acepções de gesto disponíveis na literatura sobre dança acabam sendo demasiadamente vagas com relação ao estabelecimento desse elemento no contexto da dança. A questão que permanece é a da definição do que é gesto em uma semiose substancialmente corporal. Nesse ponto, os estudos do gesto trazem uma definição mais precisa de seu objeto. Entretanto, cabe ressaltar que esses estudos baseiam-se em gestos que acompanham a fala, ou seja, gestos pertencentes a uma modalidade (visual) diversa daquela do discurso verbal (auditiva). Esse fator delimita claramente a distinção dos elementos linguísticos e gestuais. O mesmo não ocorre em dança, já que elementos técnicos e gestuais são produzidos através de um mesmo canal, o visual, assemelhandose, nesse ponto, às línguas sinalizadas, que têm a mesma modalidade tanto para o elemento linguístico quanto para o gestual. Nesse sentido, minha proposta contribui para uma melhor definição do elemento gestual em dança, já que busca estabelecer níveis distintos para movimentos técnicos e gestos.

\subsection{Estrutura tríplice}

Kendon (2004, p.15) define a gestualidade como ação que manifesta expressividade deliberada, ação essa entendida como movimentos corporais visíveis e dependentes do contexto para ser interpretados como elementos semióticos. Essa gestualidade é meu objeto de estudo. E, para poder definir esse objeto em uma narrativa dançada, parto da proposta de Poyatos (2002), que divide o discurso verbal em uma estrutura tríplice, adaptando-a ao discurso dançado. Poyatos estabelece, para o discurso verbal, uma estrutura composta por três níveis distintos: verbal, paralinguístico e quinésico. Esses níveis se integram entre si e atuam simultaneamente na construção do significado. O nível verbal compõe-se tanto de elementos segmentáveis (como vogais e consoantes, fonemas, morfemas, sintagmas e estrutura sintática), quanto de elementos suprassegmentais (como a entoação com seus graus de tonicidade, altura e curvas). Os elementos paralinguísiticos são qualificadores e modificadores da voz, determinados ou idiossincráticos. Esses elementos são divididos em $(i)$ qualidades primárias - que agregam informações sobre o falante, como idade, origem, gênero, estado emocional, entre outras -; (ii) qualificadores - diferentes tonalidades de voz -; (iii) diferenciadores que caracterizam estados fisiológicos, ligados a reações involuntárias, e estados 
psicológicos ligados a reações emocionais -; e (iv) alternantes - cliques de língua, fricções nasais, 'Uh-hu', 'Uh-uh', entre outros, que funcionam como palavras na interação. O terceiro nível - a quinese-, consiste em gestos, maneiras e posturas, conscientes ou inconscientes, isolados ou justapostos a palavras e/ou à paralinguagem. Como não é possível ao nível verbal carregar sozinho todo o peso da conversação (p. 104), os elementos paralinguísticos e quinésicos irão compor o discurso junto com os elementos verbais. Os elementos quinésicos, além de funcionar como redundância (enquanto marcadores emocionais), também funcionam como dispositivos econômicos no sentido de acrescentar informação de forma gestáltica, simultaneamente à mensagem verbal ou a ela se antecipando (p. 111). Reproduzo, abaixo, a Figura 4.1 de Poyatos (2002), que oferece a análise de um trecho de interação, com base nessa estrutura tripartite do discurso verbal.

\begin{tabular}{|c|c|c|}
\hline VERBAL & PARALINGUÍSTICO & QUINÉSICO \\
\hline & $\begin{array}{l}\quad\left[>\mathrm{Tz}^{\prime}>\text { :] }\right. \\
\text { clique apico-alveolar }+ \\
\text { ingressão faringeal }\end{array}$ & $\begin{array}{l}\text { sobrancelhas começam a se } \\
\text { elevar }\end{array}$ \\
\hline We-e-e-ell, & $\begin{array}{l}\text { alongamento de tom médio } \\
\text { a alto }\end{array}$ & \multirow{2}{*}{$\begin{array}{l}\text { contato direto de olhos } \\
\text { com olhos bem abertos, } \\
\text { sem piscar } \\
\text { sobrancelhas } \\
\text { elevadas }\end{array}$} \\
\hline George! & tom baixo & \\
\hline & pausa paralinguística & pausa quinésica \\
\hline What did you think & tom baixo-alto-baixo & $\begin{array}{l}\text { sobrancelhas franzidas }+ \\
\text { pálpebras baixas }+ \text { aceno } \\
\text { de cabeça }\end{array}$ \\
\hline of that girl, & tom baixo mantido & $\begin{array}{l}\text { sobrancelhas ainda } \\
\text { franzidas + aceno lateral de } \\
\text { cabeça apontando para o } \\
\text { referente ausente }\end{array}$ \\
\hline uh?! & tom alto & $\begin{array}{l}\text { olhos mais abertos, seguido } \\
\text { de piscada de olho }+ \\
\text { distensão unilateral do } \\
\text { lábio (sorriso) }\end{array}$ \\
\hline
\end{tabular}

Figura 1. Reprodução de análise baseada na estrutura tríplice de Poyatos (2002, figura 4.1)

A interação tem início com um elemento paralinguístico e um elemento quinésico que dão indicações da intenção do falante. $\mathrm{O}$ alongamento da vogal com variação tonal, mais a expressão facial, têm um significado completamente diferente da 
emissão de "Well..." sem alongamento, em tom baixo ou com uma configuração de pálpebras baixas. O tom aumentado na palavra you, com o aceno de cabeça, poderiam não ser utilizados caso a pessoa que estivesse perguntando não quisesse contrastar sua opinião com a do interlocutor, por exemplo. Da mesma forma, a referência a uma pessoa ausente pode ser feita através de um apontamento com a mão, sem o aceno de cabeça. O marcador discursivo pode acontecer com alongamento vocálico, porém sem sorriso, ensejando outro tipo de interpretação, completamente diferente daquela descrita acima. Aliás, o mesmo grupo de palavras pode referir-se a uma situação bastante diversa, como, por exemplo, uma situação de desconfiança, na qual os elementos paralinguísticos e quinésicos utilizados pelo falante seriam completamente diferentes. A análise através de uma estrutura tríplice mostra como é importante a interação dos elementos dos três níveis para a construção da significação.

Tomando como base essa proposta de análise de discurso verbal, sugiro que a construção da significação no discurso dançado se fundamenta no trabalho conjunto de três níveis interrelacionados. O primeiro deles é o técnico. O nível técnico é constituído pelos movimentos convencionalizados dentro de uma determinada técnica de dança. Ele pode ser aproximado ao nível verbal, pelo fato de que a técnica de dança se constitui de elementos segmentáveis, encadeados temporalmente. O segundo nível é o paraquinésico, que atua sobre a técnica de dança, acrescentando-lhe qualidades, por exemplo, no controle de energia empregada para a realização de um dado movimento. Esse nível está sendo correlacionado com o nível paralinguístico, por ser composto de elementos não-segmentáveis. E, finalmente, o terceiro nível é o gestual, que se equipara ao nível quinésico do discurso verbal, composto pela postura e pela gestualidade entendida como movimento expressivo de maneira ampla e não restrita a articuladores manuais. A ordem dos níveis não corresponde a uma hierarquização entre eles. Os três níveis são igualmente importantes para a constituição da significação no discurso dançado.

Diferentemente do que ocorre com a paralinguagem no discurso verbal, que interage apenas com o nível verbal, no discurso dançado, a paraquinese atua sobre os dois outros níveis. Dessa forma, os elementos paraquinésicos constroem o sentido junto com a gestualidade e a técnica. Discretizando, dessa forma, o discurso dançado, posso separar, observar e descrever os elementos que denomino gestos que acompanham a dança, traçando um paralelo com a ideia de gestos que acompanham a fala. 


\subsubsection{Nível técnico}

\subsubsection{Histórico da técnica clássica}

Uma das hipóteses mais aceitas sobre a origem da dança clássica é o ditirambo dionisíaco e os coros do teatro grego falado, com seus gestos estilizados (chamados cheironomia), utilizados por dançarinos profissionais (Cohen 1974) ${ }^{13}$. Uma origem mais recente é reconhecida nas cortes dos príncipes do norte da Itália, na Alta Renascença. Em Florença, as paradas triunfais, ou trionfi, eram organizadas pela corte dos Medici e traziam participantes mascarados em diferentes carros alegóricos que paravam defronte do trono para declamar versos, cantar e dançar. Ao final, os integrantes de todos os carros se uniam para uma grande dança. Esse evento migrou para a França por ocasião do casamento de Catarina de Medici com o futuro rei, Henrique II. Na França, os balés de corte dos séculos XV e XVI uniam poesia, música, dança e composição visual (cenários, figurinos, adereços). Conduzidos pelos reis e rainhas, seguidos por nobres, consistiam em passos e movimentos originários das danças sociais da época, que enfatizavam o decoro, a graça e a elegância. $\mathrm{O}$ desenho coreográfico era planimétrico, já que a plateia, que ocupava três lados do salão (o quarto lado era onde se sentavam o rei e a rainha a quem as danças eram dirigidas), se sentava em galerias e observava a dança de cima para baixo ${ }^{14}$.

A princípio, os balés estavam intimamente ligados ao interesse renascentista pela cultura clássica, e o simbolismo e a alegoria eram importantes elementos em suas composições. O ditirambo dionisíaco e a pantomima grega e romana eram suas importantes fontes de referência. A dança, propriamente, era um elemento entre outros da apresentação, dentre eles a música instrumental, canções, versos declamados, figurinos e efeitos especiais (Cohen 1974, p. 19). Algumas danças se originavam dos protocolos de etiqueta da corte; outras vinham de celebrações dos camponeses reelaboradas para adequação à nobreza. Tratados dos séculos XVI e XVII informam que

\footnotetext{
${ }^{13} \mathrm{O}$ ditirambo dionisíaco era um canto coral, em homenagem a Dionísio, constituído de uma parte narrativa e de uma parte coral. Com o tempo o ditirambo evoluiu para o drama, na forma teatral como a conhecemos hoje. As danças, que eram descontroladas e caóticas, passaram a ser organizadas e elaboradas (cf. http://pt.wikipedia.org/wiki/Ditirambo).

${ }^{14} \mathrm{O}$ termo planimétrico se refere ao desenho que as coreografias traçavam no chão, através dos passos, aproveitando o fato de a plateia estar em posição superior aos dançarinos e ter ampla visão do chão. Esse termo se opõe a estereométrico, que se refere ao desenho que as coreografias executam no espaço tridimensional, levando em consideração a posição frontal da plateia.
} 
a dança estava dividida em dois tipos, sendo um lento e solene, com os pés mantidos sempre perto do chão, e o outro mais vivaz, com elevação dos pés.

Posteriormente, foram introduzidas novas formas como o ballet-mascarade, em que as danças, precedidas de uma declamação ou de uma canção, traziam uma narrativa mais breve e superficial, e o ballet à entrées, em que as múltiplas entradas em cena se uniam em torno de um tema comum. Também a sátira foi incorporada aos espetáculos, encorajando o crescimento de danças pantomímicas, pois o uso de máscaras suprimia as expressões faciais dos intérpretes e tornava necessário enfatizar o recurso corporal para a individuação das personagens. A pantomima trouxe também elementos acrobáticos para a dança, fazendo com que o caráter aristocrático do balé se diluísse. A dança deixava de emular esculturas greco-romanas, em um ideal de perfeição plástica, porém estática, para seguir em direção ao retrato de hábitos humanos, através de mímica e postura expressiva.

Durante o reinado de Luis XIII ocorreu a mudança da plateia para apenas um lado do palco, o que fez com que os coreógrafos passassem a lidar com a composição frontal. Partindo ainda do desenho coreográfico sobre o piso, as composições incorporaram aspectos de profundidade, criando efeitos de alto-relevo para espectadores que se encontravam, aproximadamente, à mesma altura do palco, colocando em evidência a figura do bailarino. Pequenos saltos com batidas dos pés e uma variedade de piruetas foram introduzidos e houve um aumento na rotação dos pés, que passaram a formar um ângulo de noventa graus. Nesse período, foi introduzido também o proscênio $^{15}$, um arco na parte anterior do palco, que levou a uma mudança na postura daqueles que assistiam às danças: a distância imposta por esse recurso espacial fez com que a participação da plateia diminuísse em favor da observação.

No reinado de Luis XIV, o modo como o cavalheiro se portava no palco, como fazia a reverência, como tomava a mão da companheira, sua consciência da elegância dos movimentos, entre outros, eram aspectos que estabeleciam uma hierarquia na corte (os mais hábeis eram mais bem sucedidos junto ao rei). Ao fundar a Academia Real de Dança, em 1661, Luis XIV indicou vivamente a prática da dança não apenas para a participação nos bailados, mas também para o aprimoramento no uso das armas.

Também em 1661, Molière criou os comédies-ballet, que ligavam dança e música ao roteiro de uma peça. Por misturar nobres e profissionais em seus elencos, os

${ }^{15} \mathrm{O}$ termo proscênio refere-se à parte anterior do palco, em formato oval. Ver figura 2 adiante. 
comédies-ballet são geralmente considerados a forma transitória entre os balés de corte e um movimento de profissionalização da dança que se verificava nesse período. JeanBaptiste Lully, compositor e dançarino, foi um dos colaboradores de Molière e dominou a Opéra de Paris de 1672 a 1687, contribuindo sobremaneira para a profissionalização tanto da dança como da ópera. Em colaboração com Pierre Beauchamps, mestre de danças, e Philippe Quinault, libretista, criou a tragédie lyrique, em que dança e música serviam a uma trama. A mímica corporal era bastante presente, pois os bailarinos ainda usavam máscaras, o que eliminava a possibilidade de expressão facial.

Em 1702, Beauchamps codificou a técnica de balé existente, e a ele se deve a identificação das cinco posições canônicas dos pés (a serem apresentadas na próxima seção) sobre as quais foram edificados os passos de balé que reconhecemos como técnica clássica. Os estilos de dança feminino e masculino se adequavam ao decoro de então, mas era imperativo a ambos transmitir a sensação de facilidade e falta de esforço para a execução das danças. Curiosamente, a posição aberta dos pés, símbolo dessa técnica na atualidade, advém do estilo utilizado nas danças grotescas da época.

Louis Pécour, discípulo e sucessor de Beauchamps na direção da Opéra de Paris, desenvolveu junto com o compositor André Campra uma nova forma de apresentação chamada opéra-ballet. Sendo igualmente uma combinação de música vocal e dança, seus temas eram mais leves que os das tragédies-lyriques, e suas ambientações mais exóticas. A dança começava a ganhar mais expressividade, tornando-se tão eloquente quanto a música vocal e o teatro. Surgia o ballet d'action, que desenvolvia a história apenas com base em movimentos corporais, trazendo o elemento dramático para $\mathrm{o}$ espetáculo $^{16}$. Jean Georges Noverre, em 1760, publicou Lettres sur la dance et sur les ballets, na qual clamava por reformas nas fórmulas do balé de corte, cheias de simbolismos e abstrações, em prol de um espetáculo construído de maneira coerente, com maior interação entre coreógrafo, compositor, cenógrafo e figurinista no processo de composição da peça. Ele também protestava contra o uso de máscaras, já que acreditava que a expressão facial dos bailarinos reforçava seus gestos e era fundamental para a comunicação da emoção para a audiência. Após a Revolução Francesa, os teatros de corte foram substituídos pelos teatros municipais, que, sendo maiores que aqueles,

\footnotetext{
${ }^{16}$ Em contrapartida, a commedia dell'arte italiana e as pantomimas francesas e inglesas incorporavam a dança em uma faceta mais acrobática, utilizando exageros gestuais e linguagem corporal para transmitir seu conteúdo.
} 
demandavam uma ampliação dos delicados e finos movimentos nascidos nos salões de baile.

No século XIX, foram fixadas as características que hoje identificamos como pertencentes ao balé, como a técnica de pontas, em que a bailarina dança nas pontas dos pés, e o tutu, a saia feita de tule para emprestar um efeito de leveza aos movimentos da bailarina. Aliás, a figura feminina foi supervalorizada, em detrimento da figura do bailarino, que, naquela época, acabou se tornando um coadjuvante para as personagens centrais femininas.

No final do século XIX e início do século XX, com a criação da companhia de Sergei Diaghilev, chamada Ballets Russes, baseada em Paris, o balé ganhou autonomia e estatuto de paridade com outras artes, como a pintura, escultura, arquitetura, poesia e música. Nessa companhia surgiram nomes que iriam se tornar lendas do balé, como Mikhail Fokine, Vaslav Nijinsky e George Balanchine. No início do século XX, o advento da dança moderna trouxe elementos inovadores para as montagens clássicas e introduziu um novo estilo, tendo por base a técnica clássica, mas prescindindo de uma narrativa explícita. Coreógrafos manipularam o vocabulário técnico clássico, ampliando suas possibilidades expressivas, alguns se atendo exclusivamente aos gestos convencionalizados, em um movimento mais purista de preservação da semântica e da estética do movimento técnico, outros trabalhando com uma visão mais naturalista do gesto que acompanha a dança, de modo a fazer emergir o movimento técnico a partir de uma ação natural (Cohen 1974).

As montagens dos clássicos ainda é bastante prestigiada pelas companhias tradicionais, como no caso das montagens de O Quebra-Nozes, por ocasião do Natal, feitas por companhias americanas, europeias e brasileiras. Suas execuções, no entanto, trazem elementos oriundos da dança moderna, como, por exemplo, um uso mais livre do corpo, em contraponto à codificação de passos e movimento de braços (que favorece o trabalho dos membros em detrimento do uso do torso) (Courtine 2006). Essa influência pode ser percebida nas versões de Romeu e Julieta escolhidas para este estudo $^{17}$.

\footnotetext{
${ }^{17}$ Ambas as coreografias estão inseridas na categoria balé de repertório. O balé de repertório narra uma história, através das danças, pantomimas e gestos, fato que possibilitou a análise das versões. (Nota inserida por sugestão da banca examinadora.)
} 


\subsubsection{Técnica clássica}

Vários tratados sobre a técnica de dança se sucederam até o estabelecimento da técnica clássica como a conhecemos hoje ${ }^{18}$. Entre outros, contribuíram para o desenvolvimento da dança teatral Claude Ménestrier, Raoul Feuillet, John Weaver, Pierre Beauchamps, Jean-Georges Noverre, Carlo Blasis, Auguste Bournonville e Enrico Cecchetti. Seu desenvolvimento deve-se à valorização do movimento corporal como instrumento para a interpretação, deixando de lado a caracterização por meio de figurinos, máscaras e versos. A técnica clássica foi desenvolvida para a execução da dança teatral, levando em conta o tipo de palco no qual ela era apresentada, o palco italiano $^{19}$. Esse palco caracteriza-se por um formato quadrado em sua porção central, com um prolongamento oval em sua parte anterior, voltado para a plateia, chamado proscênio. As linhas tracejadas, na figura abaixo, mostram a divisão que é feita para a localização espacial em cena. A linha laranja divide o palco nas suas porções anterior (próxima ao proscênio) e posterior (próxima ao fundo do palco), enquanto a linha vermelha indica a divisão entre o lado direito e o lado esquerdo do palco. As linhas contínuas marcam as diagonais: a verde liga o canto direito anterior ao canto esquerdo posterior e a preta vai do canto esquerdo anterior ao canto direito posterior. As laterais do quadrado central são chamadas coxias e sua parte posterior é a rotunda, que pode ser reta ou semicircular, como indicado na figura abaixo:

\footnotetext{
${ }^{18}$ Neste trabalho, não faço distinção entre aspectos específicos das diferentes escolas que desenvolveram a técnica clássica ao longo dos séculos (italiana, francesa, inglesa, russa, dinamarquesa e cubana, entre as mais proeminentes).

${ }^{19}$ Há uma distinção entre palco italiano, palco elisabetano e palco de arena. O primeiro é aquele descrito no texto. O segundo é um palco que tem três lados voltados para a plateia (em vez de um, como no caso do italiano) e o último designa o palco que é rodeado por plateia (ou seja, não há rotunda ou coxias, pois o quadrado central é visível por todos os lados). O termo palco refere-se sempre ao quadrado central, apresentado na figura 2 .
} 


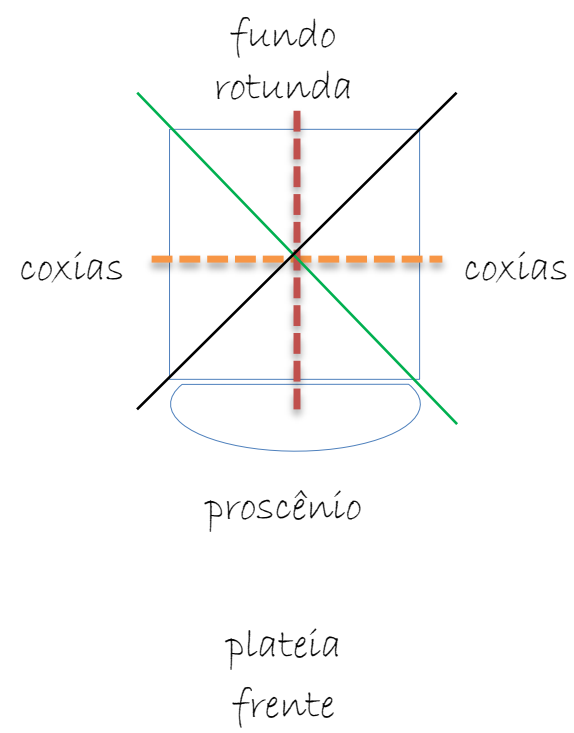

Figura 2. Perspectiva do palco italiano

As posições básicas, e aquelas que se desenvolveram a partir delas, levam em consideração essa disposição espacial. Em outras palavras, a configuração do palco está diretamente associada à mudança da técnica de dança. A técnica passa a enfatizar a desenvoltura do bailarino para realizar as inovações decorrentes da mudança de perspectiva da plateia ${ }^{20}$. Inclui-se aí o aumento da rotação dos pés e das pernas, e o aumento dos movimentos de pernas e braços em geral, para viabilizar sua leitura pelo público, distanciado dos bailarinos pela imposição do proscênio.

Assim, a descrição da técnica clássica parte de cinco posições básicas de pés (estabelecidas por Beauchamps em 1702) e de braços que, associadas a posições do torso, compõem o repertório de passos. Os passos, encadeados, formam a base das sequências chamadas frases coreográficas. Estas, agrupadas em sequências maiores, constituem a coreografia, que, associadas aos níveis paraquinésico e gestual, constituem o que chamo de discurso dançado.

As cinco posições básicas dos pés são as ilustradas abaixo, com o alinhamento simétrico das cinturas pélvica (quadris) e escapular (ombros), posicionamento de ambos os pés firmados no chão e com o peso do corpo distribuído igualmente entre os dois pés, independentemente da distância entre eles:

\footnotetext{
${ }^{20}$ Retomando o que foi dito na seção anterior, houve a introdução de pequenos saltos com batidas de pés e de novas formas de giros, além da valorização do desenho estereométrico, que, adicionado ao desenho planimétrico, enfatizava a tridimensionalidade.
} 
i) Primeira posição - calcanhares juntos, pés virados para fora em linha reta (Fig.3).

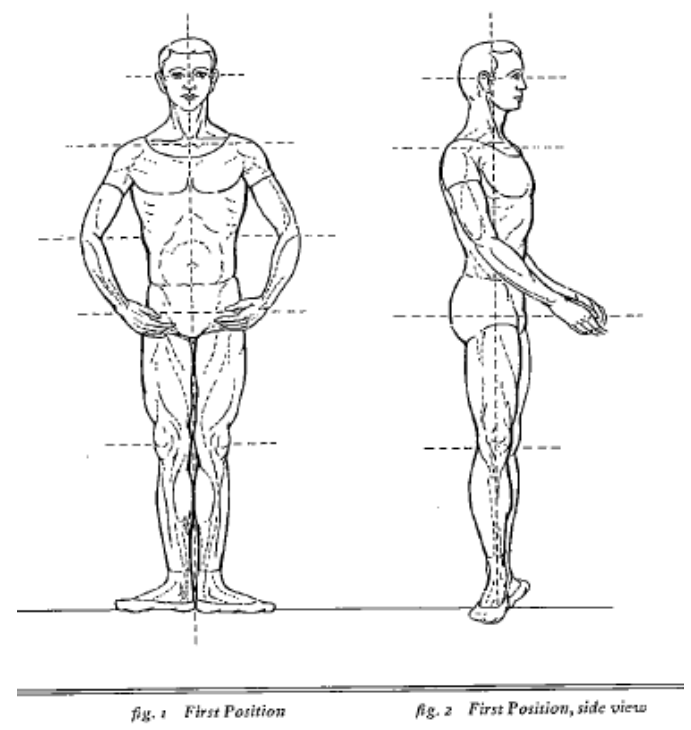

Figura 3. Primeira posição de pés, frontal e lateral, retirada de Kirstein, Stuart e Dyer (1952, p. 32) $)^{21}$

ii) Segunda posição - pés virados para fora em linha reta, separados pela distância de um pé (Fig.4).

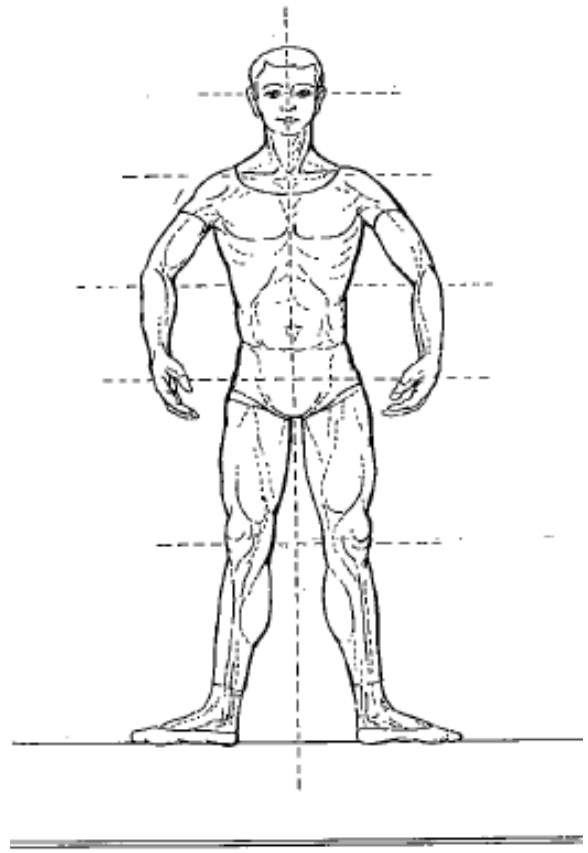

fig. 3 Second Position

Figura 4. Segunda posição de pés, retirada de Kirstein, Stuart e Dyer (1952, p. 32).

\footnotetext{
${ }^{21}$ As ilustrações foram retiradas do livro The Classic Ballet, de Kirstein, Stuart e Dyer (1952), e são de autoria de Carlus Dyer.
} 
iii) Terceira posição - pés virados para fora, calcanhares colocados um em frente ao outro (Fig.5).

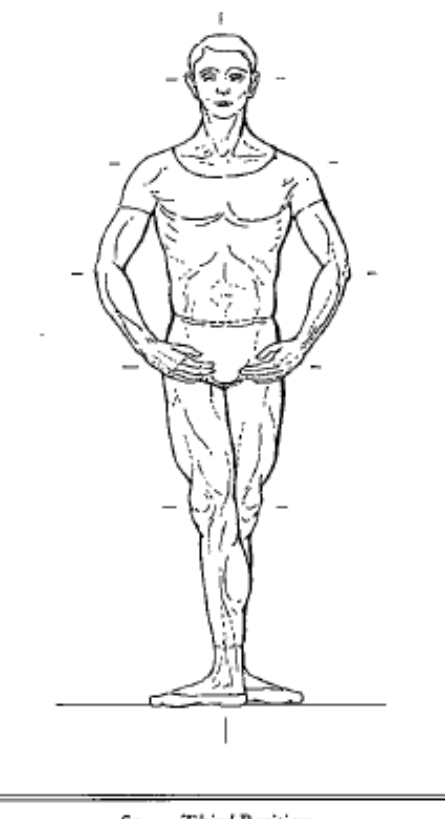

fig. 4 Third Position

Figura 5. Terceira posição de pés, retirada de Kirstein, Stuart e Dyer ( 1952, p. 33).

iv) Quarta posição - pés virados para fora, um pé colocado na frente do outro em linha paralela, separados por um pé de distância (calcanhares e ponta dos pés ficam em linha formando um quadrado).

Variação: quarta posição ouverte - pés virados para fora, um pé colocado na frente do outro em linha paralela, separados por um pé de distância (apenas os calcanhares alinhados, sem formação do quadrado) (Fig.6). 


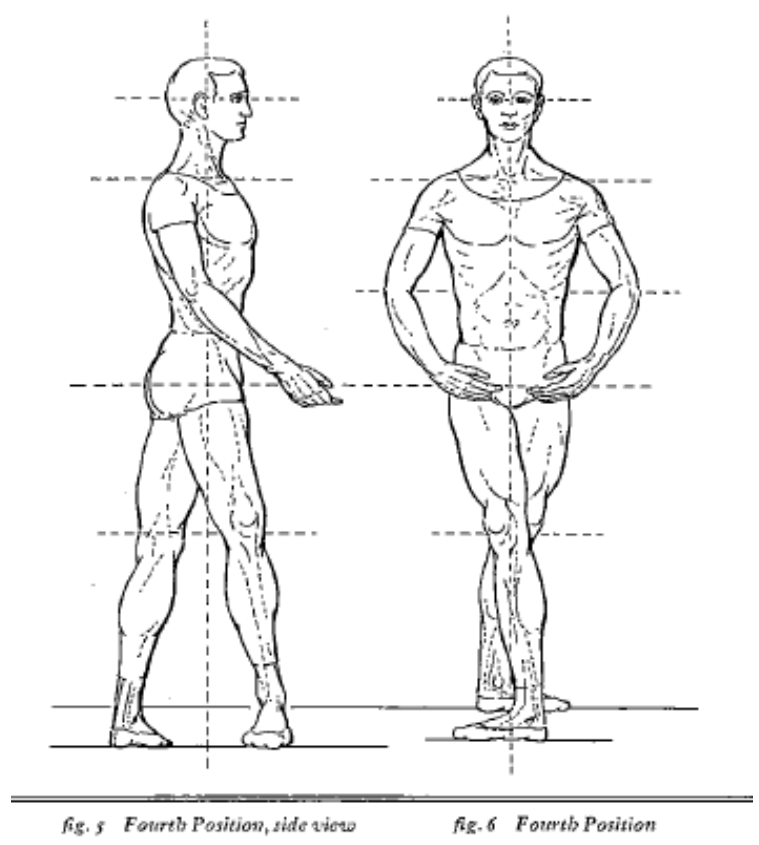

Figura 6. Quarta posição de pés, lateral e frontal, retirada de Kirstein, Stuart e Dyer (1952, p. 33).

v) Quinta posição - pés virados para fora, um pé colocado exatamente na frente do outro, a primeira junta do dedão projetada para além dos calcanhares (Fig.7).

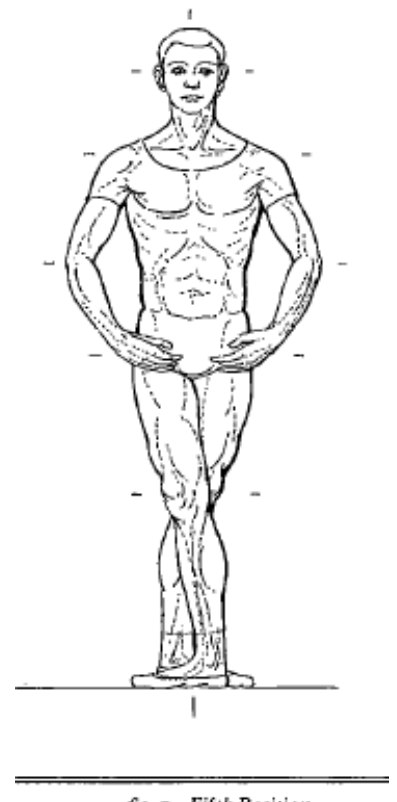

fig. 7 Fiftl Position

Figura 7. Quinta posição de pés, retirada de Kirstein, Stuart e Dyer (1952, p. 33). 
Essas posições dos pés são usadas para a recuperação da linha central de equilíbrio, que passa pelo centro do corpo e tem seu ponto central no baixo abdômen, como, por exemplo, em momentos de recuperação depois de um salto de difícil execução, ou quando o corpo tem que se inclinar para frente ou para trás. As posições fechadas (primeira, terceira e quinta posições) costumam ser utilizadas ao final das frases coreográficas que enfatizam a verticalidade do corpo ${ }^{22}$. As posições abertas (segunda e quarta posições) são, geralmente, posições de transição na transferência de peso de uma perna a outra: a quarta posição pode ser executada em final de frase com a flexão da perna anterior e maior distanciamento da perna posterior não flexionada, passando a ser denominada quarta allongée. Nessa posição de final de movimento, o torso é inclinado levemente para frente para acomodar a posição da perna que está atrás do corpo. Nesse caso, ela não é utilizada para enfatizar o eixo vertical, pois está mais ligada à estabilidade, podendo ainda servir como posição de transição entre dois movimentos, ou como posição final de sequência de passos.

As cinco posições básicas de braços são as seguintes, também com alinhamento simétrico das cinturas pélvica e escapular, ilustradas na sequência:

i) Primeira posição - braços em posição baixa, à frente do corpo, com cotovelos levemente flexionados e dedos alinhados com o centro do corpo. Variação: primeira posição alta - braços com cotovelos levemente flexionados erguidos à altura do peito, dedos alinhados com o centro do corpo (Fig.8).

\footnotetext{
${ }^{22} \mathrm{O}$ aprendizado dessas posições segue exatamente essa ordem, pois ocorre um incremento na dificuldade de execução técnica da primeira para a terceira posição, e desta para a quinta posição. A terceira posição dificilmente estará presente em uma coreografia, pois tem uma finalidade pedagógica: trata-se da uma posição intermediária entre uma posição em que as pernas estão unidas apenas por sua face interna (primeira) e outra na qual a união se dá por outras faces da perna (frontal e posterior) com consequente fechamento da posição. Por ser uma posição que exige maior rotação dos pés e das pernas para poder ser realizada dentro dos parâmetros ideais, a quinta posição é ensinada aos estudantes em fase posterior, após a apropriação das duas anteriores.
} 


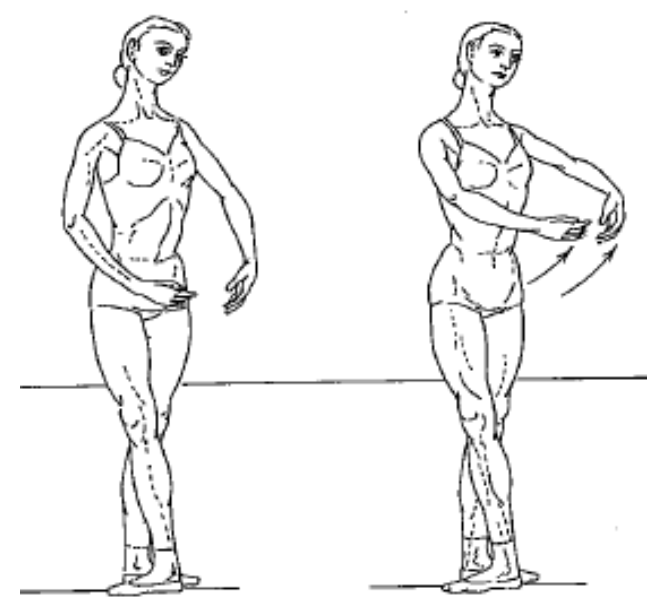

Figura 8. Primeira posição e primeira posição alta de braços, retirada de Kirstein, Stuart e Dyer (1952, p. 98).

ii) Segunda posição - braços estendidos para os lados, cotovelos levemente rotacionados para trás, palmas das mãos viradas para frente (Fig.9).

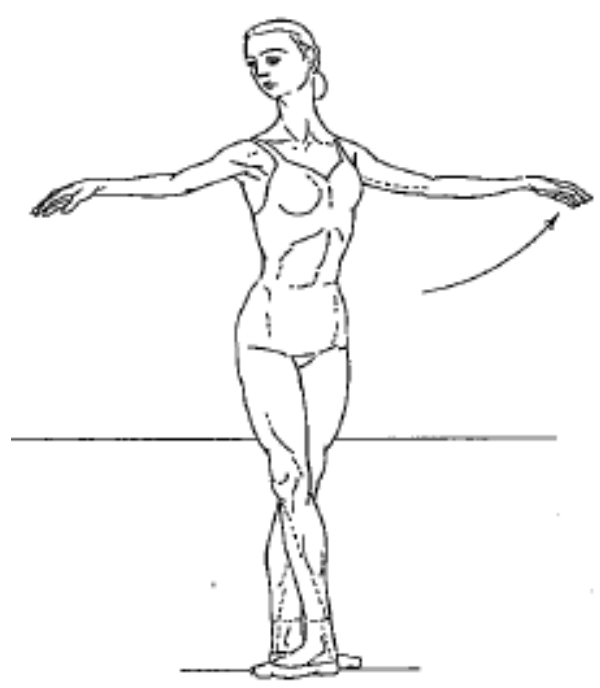

Figura 9. Segunda posição de braços, retirada de Kirstein, Stuart e Dyer (1952, p. 99).

iii) Terceira posição - um braço estendido para o lado, como na segunda posição, o outro braço colocado como na primeira posição alta.

Variação: terceira posição alta - um braço estendido para o lado, como na segunda posição, o outro braço colocado acima da cabeça, como na primeira posição, dentro do campo de visão (Fig.10). 


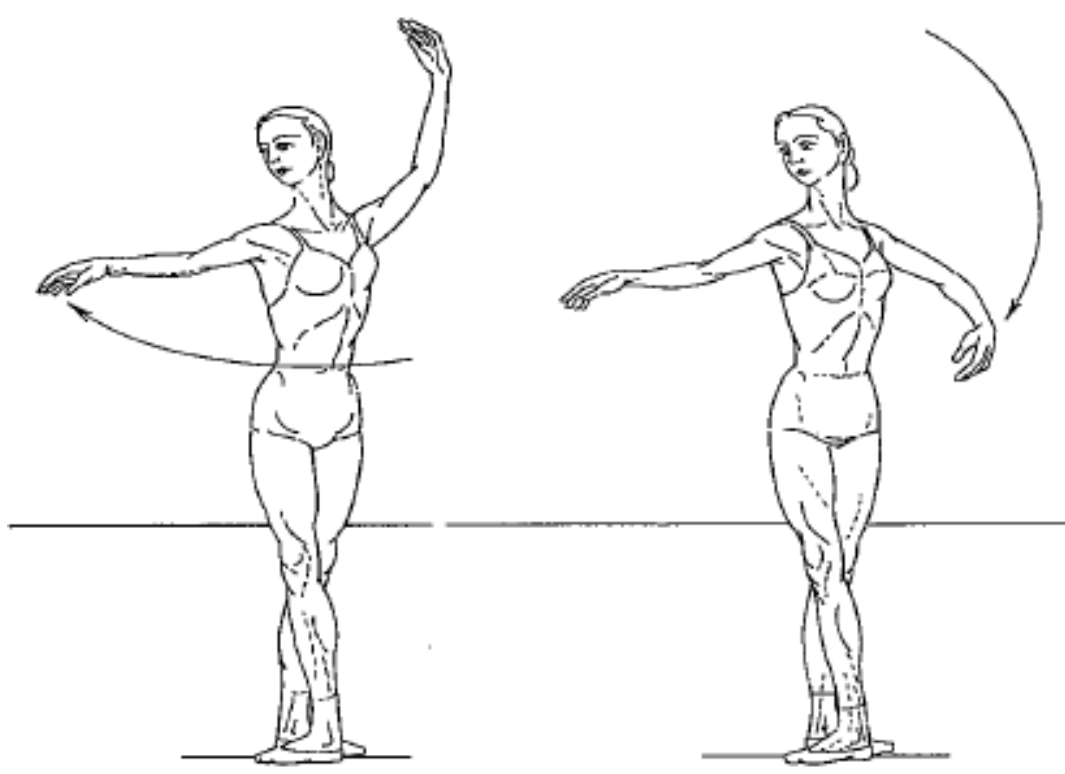

Figura 10. Terceira posição alta e terceira posição de braços, retirada de Kirstein, Stuart e Dyer (1952, p. 99).

iv) Quarta posição - um braço colocado em primeira posição alta, o outro braço colocado acima da cabeça, como na primeira posição, dentro do campo de visão (Fig.11).

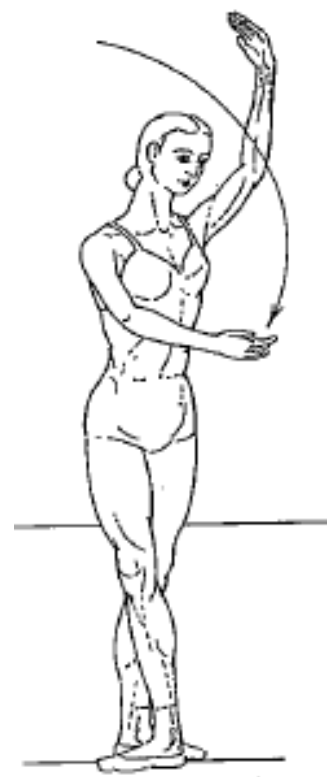

Figura 11. Quarta posição de braços, retirada de Kirstein, Stuart e Dyer (1952, p. 98).

v) Quinta posição - os dois braços colocados acima da cabeça, como na primeira posição, dentro do campo de visão (Fig.12). 


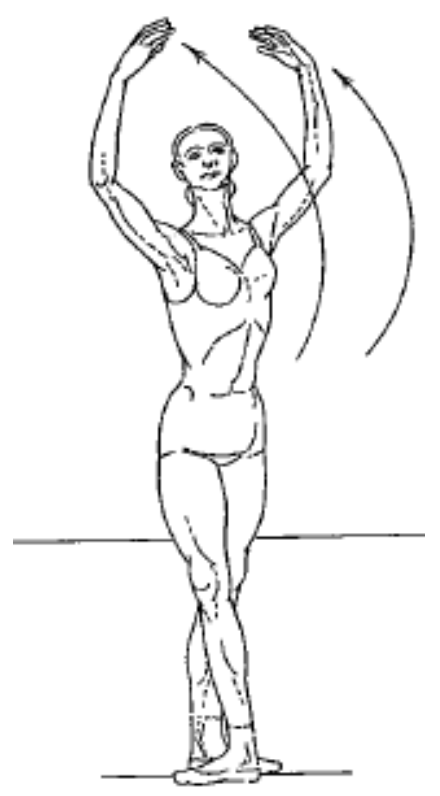

Figura 12. Quinta posição de braços, retirada de Kirstein, Stuart e Dyer (1952, p. 98).

A posição da cabeça e do tronco superior é parte integrante da postura global para a realização da posição de braços e varia de acordo com o método de ensino ${ }^{23}$. Essas posições de cabeça e tronco foram estabelecidas pela escola francesa antiga posteriormente às posições dos pés. Além de ser parte da representação do estilo (clássico, romântico ou moderno), os braços servem de moldura para a cabeça e o torso, tendo um papel bastante relevante no estabelecimento da forma e do significado. Pequenos saltos costumam ser acompanhados das posições baixas de braço, ao passo que os grandes saltos costumam usar a postura mais elevada. Dessa forma, os braços reforçam as propriedades que qualificam os saltos. Há, no entanto, a possibilidade de usar uma quinta posição de braços, ou uma quarta posição alta em pequenos saltos com bateria, ajudando a impulsão do bailarino e favorecendo sua permanência no ar para a execução de um maior número de batidas dos pés ${ }^{24}$. Os braços são utilizados também para a obtenção do equilíbrio entre as porções superior e inferior do corpo.

\footnotetext{
${ }^{23}$ Os seis principais métodos são o francês, o russo (conhecido como método Vaganova), o cubano, o inglês (também chamado Royal), o italiano (Cecchetti) e o dinamarquês (Bournonville).

${ }^{24}$ Pequenos saltos com bateria são executados a pequena distância do chão, com a troca sucessiva dos pés marcada pelo encontro das faces anterior e posterior das coxas, pernas e pés enquanto o bailarino está no ar. Quanto menor o número de trocas das pernas, mais simples é a bateria e mais próxima do chão ela poderá ser executada. Um maior número de trocas das pernas exigirá maior tempo no ar e, portanto, maior distância do chão.
} 
As três posições básicas do corpo, também com simetria das cinturas pélvica e escapular, ilustradas abaixo, são:

i) En face - corpo colocado paralelamente à frente do palco (Fig.13).

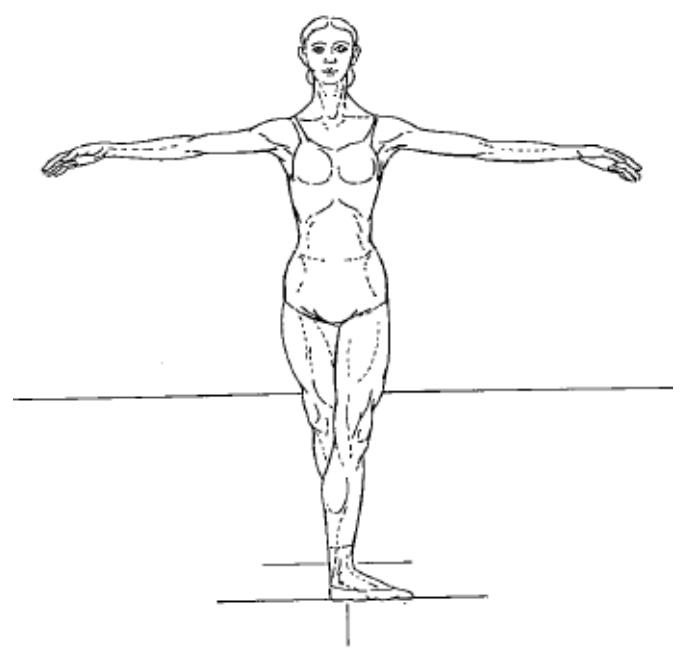

Figura 13. Posição en face, retirada de Kirstein, Stuart e Dyer (1952, p. 87).

ii) Éffacé - corpo colocado em posição diagonal em relação à frente do palco com a perna em movimento em posição aberta para o público em relação à perna de apoio (Fig.14).

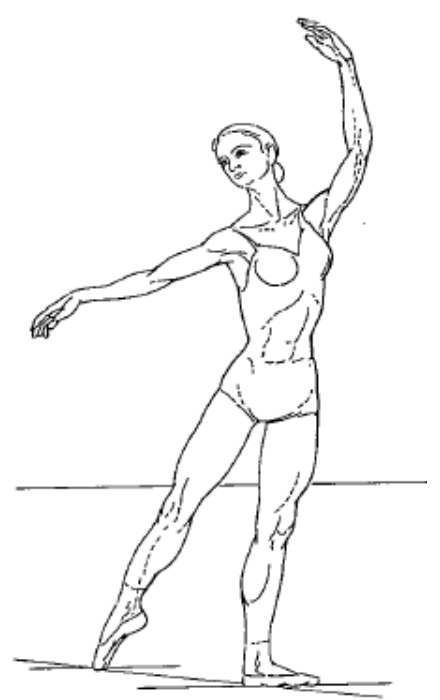

Figura 14. Posição éffacé, retirada de Kirstien, Stuart e Dyer (1952, p. 87). 
iii) Croisé - corpo colocado em posição diagonal em relação à frente do palco com a perna em movimento em posição cruzada para o público em relação à perna de apoio (Fig.15).

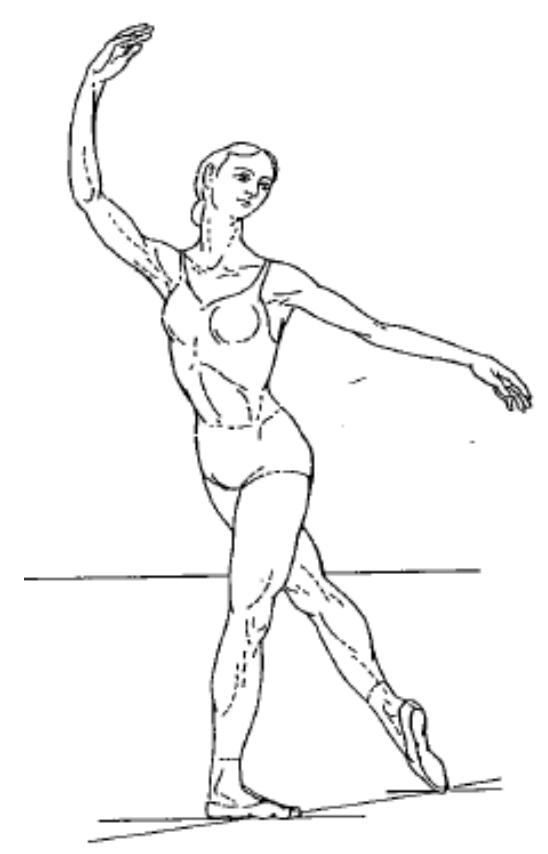

Figura 15. Posição croisé, retirada de Kirstein, Stuart e Dyer (1952, p. 87).

A posição central prevê uma neutralidade da postura, ao passo que a posição effacé estabelece uma abertura em relação ao público, em contraponto à posição croisé, que guarda alguma reserva, pois mostra os membros inferiores em uma posição fechada com relação à plateia. Essa reserva pode ser em relação à plateia, mas também em relação aos outros bailarinos.

A partir dessas posições básicas, acontece a elaboração dos passos básicos como o passé, na figura 16. Ele é iniciado com os pés em primeira, terceira ou quinta posições básicas de pés, um pé desliza pela outra perna até o joelho, formando um ângulo reto entre a coxa da perna flexionada e a perna de base. Em geral, há associação do movimento de perna com a postura de braços e posição do corpo. Esse passo servirá de base para a pirouette (giro sobre a perna de base do passé), bem como para os movimentos de developpé (a partir do passé, a perna que estava flexionada se estende para frente, para o lado ou para trás do corpo). É uma posição utilizada como passagem de uma posição básica de pés no chão (cf. figuras 3,4,5,6 e 7) para posições de perna e 
pé no ar, sempre com o intuito de enfatizar o sentido ascendente da perna em movimento.

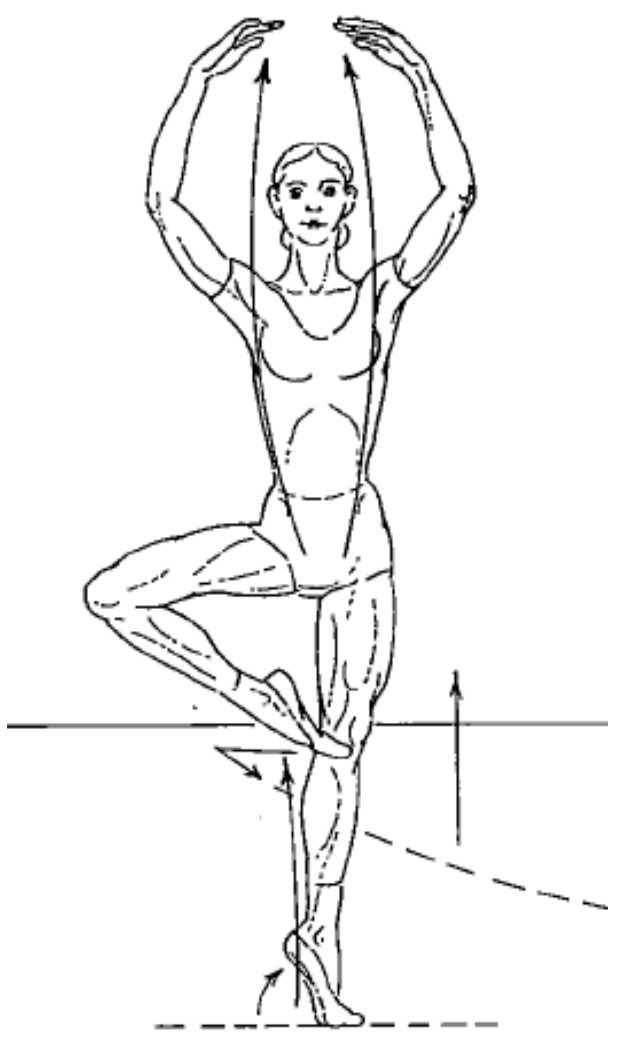

Figura 16. Passé relevé, com braços em quinta posição, retirada de Kirstein, Stuart e Dyer (1952, p. 128) ${ }^{25}$

Outro exemplo de passo básico, o arabesque, está representado na figura 17: partindo da primeira ou da quinta posição, uma perna serve de base, estendida ou flexionada, e a outra perna vai para trás em linha reta; essa posição de pernas está associada a uma postura de braços que permite a manutenção do equilíbrio e a uma posição corporal com quebra parcial da simetria entre as cinturas pélvica e escapular, já que a cintura escapular é ligeiramente inclinada para frente devido ao movimento bascular da cintura pélvica. As duas cinturas, no entanto, mantêm-se alinhadas com relação à posição frontal, conservando o alinhamento de nível. Esse movimento enfatiza o equilíbrio entre as duas cinturas, bem como o de braços e pernas.

\footnotetext{
${ }^{25}$ Aqui o passé é relevé porque o pé da perna de base está na meia ponta, posição em que o eixo central do corpo está apoiado no metatarso devido à elevação do calcanhar.
} 


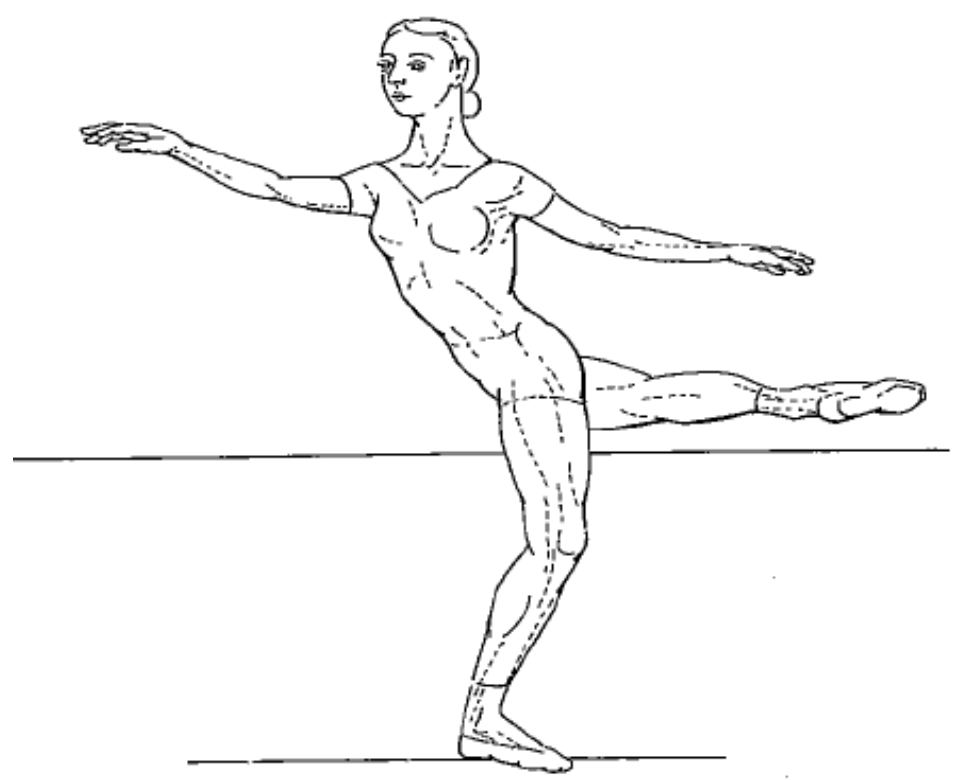

Figura 17. Quarto arabesque (croisé), retirada de kirstein, Stuart e Dyer (1952, p. 108).

Um passo elaborado, o cabriole, é executado com o lançamento de uma perna à frente do corpo, a 45 graus, e a outra perna, de base, unindo-se a ela no ar, com a batida da face anterior de uma perna com a face posterior da outra, como ilustrado abaixo ${ }^{26}$. Ao realizar a batida das pernas, o corpo bascula levemente para trás, com o braço contrário à perna que foi elevada, erguido até a terceira posição alta, para proporcionar equilíbrio entre as partes superior e anterior do corpo. Esse passo também pode ser realizado com o lançamento da perna para trás, em arabesque, ouverte ou effacée, e os braços assumindo a posição de arabesque correspondente. O corpo, então, se inclina para frente, como no arabesque. Nesse caso, ele é chamado cabriole en arrière.

${ }^{26}$ A sequência do movimento, na ilustração, está representada da direita para a esquerda. 


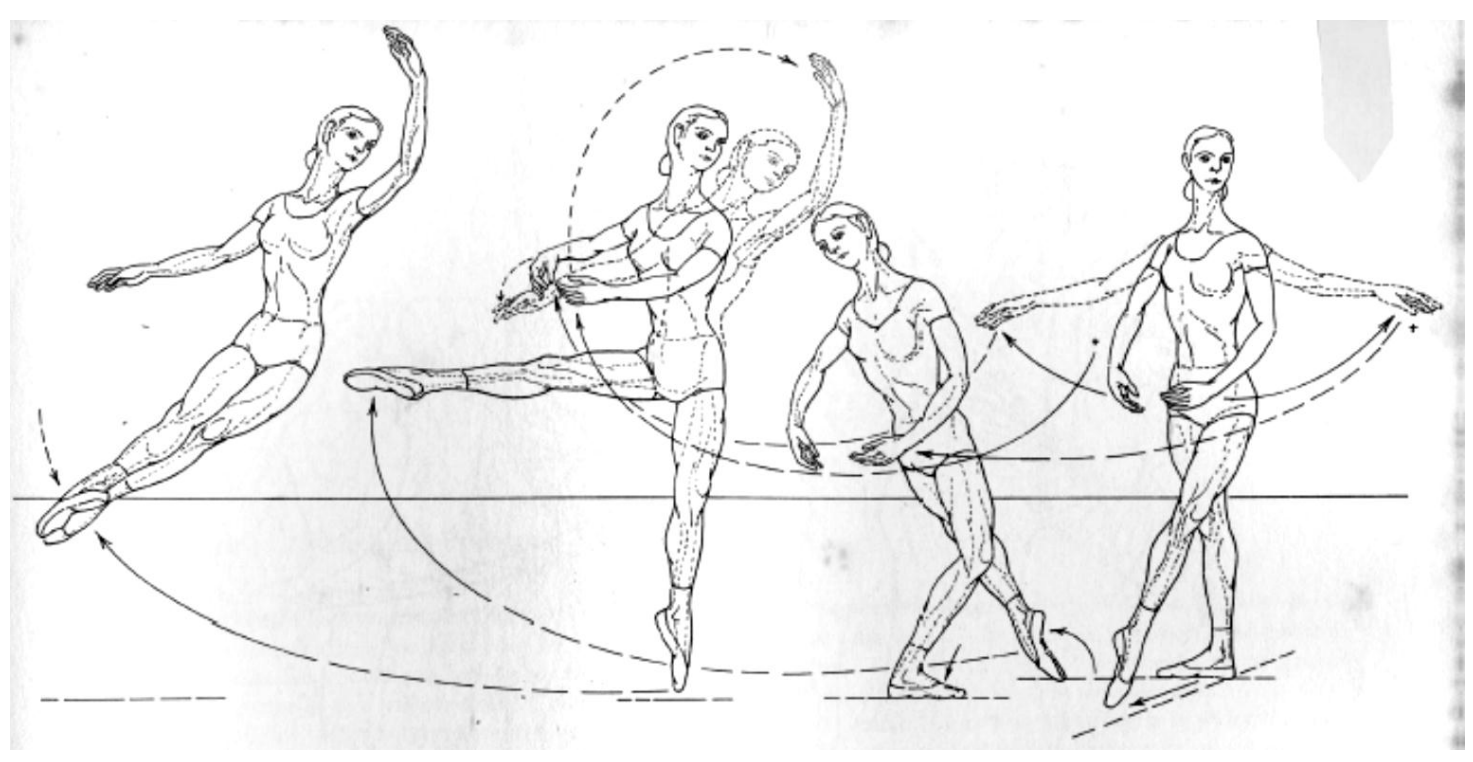

Figura 18. Cabriole en avant, retirada de kirstein, Stuart e Dyer (1952, p. 231).

Algumas equivalências podem ser feitas entre as línguas naturais e os passos da técnica de dança, e entre a coreografia e o discurso linguístico. Assim como a fala, que tem uma organização sequencial no tempo, também a coreografia segue a temporalidade da sequência dos passos. Além disso, na fala ocorrem vários processos fonológicos. $\mathrm{Na}$ assimilação, por exemplo, um som adquire características dos sons que o precedem ou o sucedem - como no caso da palavra banana, em que a vogal tônica adquire o traço de nasalidade da consoante nasal [n] que a sucede sendo pronunciada [ba'nãnə]. Na dissimilação, o som adquire um traço diferente, como na evolução da palavra lírio em português que veio da palavra latina lilium e teve o segundo som [1], aproximante lateral, dissimilado para [r], vibrante, configurando uma mudança no ponto de articulação para produção de um som diferente nas duas instâncias. No apagamento, um som é eliminado da palavra, como em cantá por cantar, em que o [r] final não é pronunciado na fala. No espraiamento de traços fonológicos, características de um som se estendem por outros sons da palavra. No exemplo da palavra banana quando pronunciada [bã'nãnə], o traço de nasalidade é espraiado tanto para a vogal átona da primeira sílaba [a], quanto para a vogal tônica.

Em dança, os passos também sofrem pequenas alterações em sua execução, como a incorporação de traços pertencentes ao passo seguinte ou elisão de traços que os compõem, quando do encadeamento na frase coreográfica. Por exemplo, determinado passo que comece, canonicamente, com uma posição média de braços (primeira posição 
alta), pode começar com uma posição alta de braços (quinta posição) devido à sua posição final no passo anterior.

Outro exemplo, ainda, é um passo que é prototipicamente executado a partir de uma certa posição de pés passar a ter seu ponto inicial alterado para possibilitar maior impulsão. No exemplo ilustrado na sequência fotográfica abaixo, ao invés de começar o grande salto a partir da quinta posição de pés ou de um failli ${ }^{27}$, a bailarina começa o grand jeté2 ${ }^{28}$ com um pé no chão e o outro em cou-de-pied, posição em que o pé que está no ar fica estendido para baixo, com o dedo mínimo do pé encostando no maléolo (osso do tornozelo) na parte anterior da perna de base ou com o pé estendido encaixado logo abaixo da panturrilha, na parte posterior da perna.

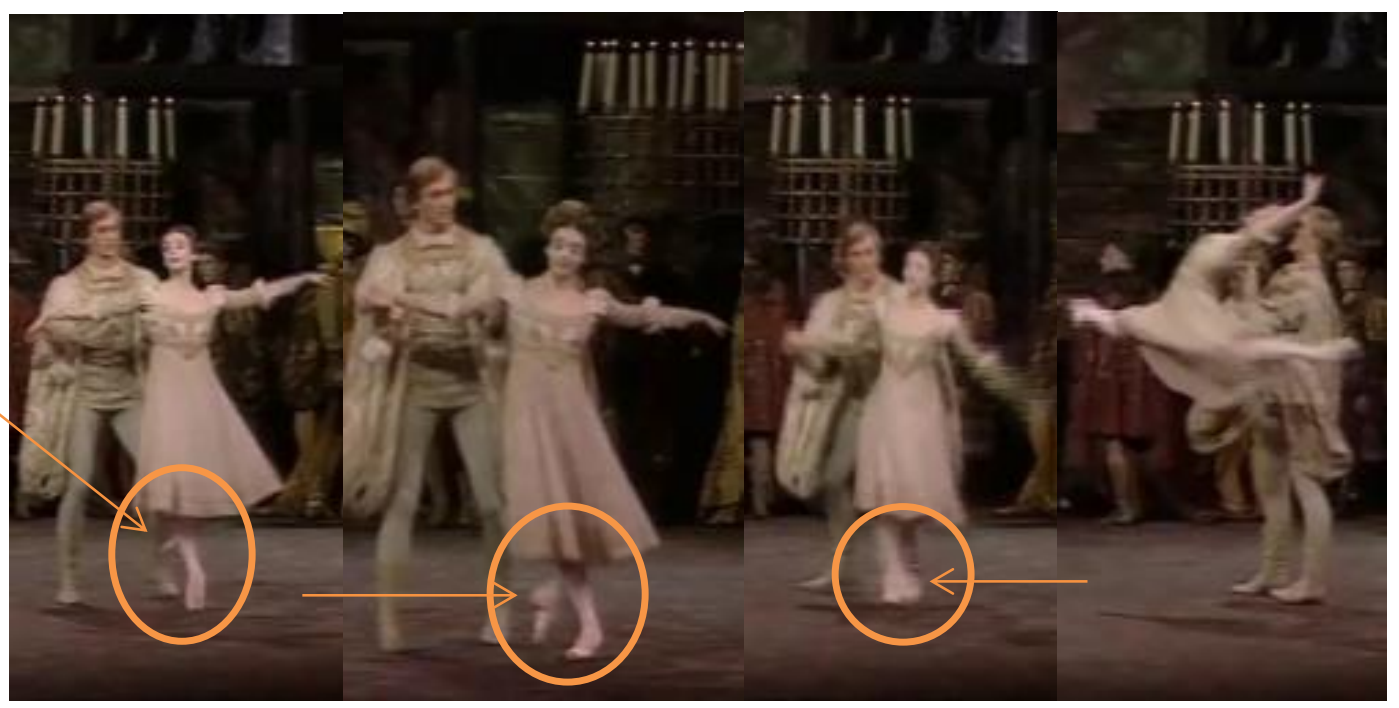

Figura 19. Alteração do ponto inicial do grand jeté, executado a partir de cou-de-pied

Mais um paralelo pode ser traçado nos eixos sintagmático e paradigmático: a sequência de passos deve obedecer às possibilidades fisiológicas, havendo restrições físicas para a escolha do passo que se seguirá a outro, do mesmo modo como existem limitações e adaptações do trato vocal para a emissão de certos sons e de cadeias sonoras. Na fala, por exemplo, ocorre a labialização, quando uma consoante como o [s], que não tem arredondamento dos lábios envolvido em sua produção, passa a ter essa propriedade articulatória quando produzida antes de uma vogal arredondada [o] ou [u].

\footnotetext{
${ }^{27}$ O failli é executado a partir do tendu derrière (posição em que uma perna se estende atrás do corpo, para longe da perna de base, com o pé estendido para baixo) ou do arabesque (cf. figura 17). A perna estendida atrás do corpo passa pela primeira posição (cf. figura 3) e termina em quarta posição, com a perna da frente flexionada e a perna de trás estendida.

${ }^{28} \mathrm{O}$ grand jeté é um grande salto da técnica clássica, realizado com a elevação de uma perna à frente do corpo impulsionando-o para o alto, possibilitando a elevação da outra perna atrás do corpo.
} 
Ou seja, é fisicamente inviável a produção do [s] sem o arredondamento dos lábios quando ele é seguido de [o] ou [u]. Em dança, um salto não pode ser executado a partir de uma posição em relevé, pois não há possibilidade de impulsão sem flexão do joelho e com o calcanhar afastado do chão. No plano sintagmático, o coreógrafo pode criar mais de uma combinação de passos para realizar um deslocamento no espaço, por exemplo, ou pode mudar apenas um passo na sequência, no plano paradigmático, mantendo os outros inalterados.

Outros aspectos, no entanto, não têm correspondência entre a técnica de dança e língua oral. Por exemplo, a predominância de um canal motor-visual, na dança, por oposição à predominância do canal vocal-auditivo na fala; na língua oral há predominância da dimensão temporal, ao passo que em dança essa preeminência está associada à dimensão espacial; diferentemente do falante que pode se ouvir ao falar, o bailarino não pode se ver ao dançar.

Quanto ao aspecto semântico da técnica, Hanna (1990) propõe uma tabela semântica para a dança em geral que interrelaciona seis dispositivos simbólicos (concretização, ícone, estilização, metonímia, metáfora e atualização) e oito esferas de interpretação (evento de dança, corpo em ação, apresentação integral, apresentação discursiva, movimentos específicos, interação com outros meios de comunicação, dança como veículo para outro meio e presença), como ilustrado abaixo:

Tabela 1 Tabela semiótica para dança em geral (Hanna 1990)

\begin{tabular}{|c|c|c|c|c|c|c|c|c|}
\hline & $\begin{array}{c}\text { evento de } \\
\text { dança }\end{array}$ & $\begin{array}{l}\text { corpo em } \\
\text { ação }\end{array}$ & $\begin{array}{c}\text { apresentação } \\
\text { integral }\end{array}$ & $\begin{array}{c}\text { apresentação } \\
\text { dicursiva }\end{array}$ & $\begin{array}{l}\text { movimentos } \\
\text { específicos }\end{array}$ & $\begin{array}{c}\text { interação } \\
\text { com outras } \\
\text { mídias }\end{array}$ & $\begin{array}{c}\text { dança } \\
\text { como } \\
\text { veículo }\end{array}$ & presença \\
\hline \multicolumn{9}{|l|}{ concretização } \\
\hline \multicolumn{9}{|l|}{ ícone } \\
\hline \multicolumn{9}{|l|}{ estilização } \\
\hline \multicolumn{9}{|l|}{ metonímia } \\
\hline \multicolumn{9}{|l|}{ metáfora } \\
\hline atualização & & & & & & & & \\
\hline
\end{tabular}

Os dispositivos simbólicos são explicados por Hanna, a partir de seu trabalho com dança, sexo e gênero, do seguinte modo: (i) a concretização é considerada como o movimento que externaliza aspectos de algo, como no caso de corte sexual que mostra as táticas de avanço e de retração; (ii) o ícone representa características formais de algo, 
como no caso do tratamento diferenciado dispensado ao bailarino que incorpora o deus do amor e da morte na cultura haitiana, como se ele fosse o próprio deus; (iii) a estilização abarca movimentos ou gestos convencionais, por exemplo, quando o bailarino aponta para seu coração como sinal de amor por sua amada; (iv) a metonímia é a conceitualização através do movimento de algo representado por uma parte ou por associação em um mesmo quadro de referência, como um dueto romântico representando uma relação mais abrangente como um casamento; $(v)$ a metáfora é a expressão de um pensamento, experiência ou fenômeno no lugar de outro a que se assemelha por analogia, juntando diferentes domínios de maneira criativa, como no caso de uma história de amor personificada por animais; e (vi) a atualização é o retrato de um ou vários papeis cotidianos do bailarino, por exemplo, quando há uma relação de sedução do bailarino com um membro da plateia e ocorre a aceitação ou a rejeição do bailarino.

Os dispositivos simbólicos parecem operar em uma ou mais esferas de interpretação, segundo Hanna. Essas esferas de interpretação são apresentadas por ela como segue: ( $i$ ) o evento de dança, em que o objetivo principal é a socialização ou o encontro de parceiros sexuais, sendo o ato de assistir à dança apenas incidental; (ii) o corpo em ação, o corpo humano em sua totalidade, como na observação de crianças brincando; (iii) o padrão completo da apresentação, que pode enfatizar estrutura, estilo, sentimento ou ação dramática; (iv) a apresentação discursiva, incluindo quem faz o que a quem e como isso é feito nos episódios dramáticos; $(v)$ os movimentos específicos e como eles são realizados, por exemplo, um bailarino parodiando uma bailarina nas pontas; (vi) a interação da dança com outros meios de comunicação, como a fala ou o figurino; (vii) a dança como veículo para outro meio, por exemplo, quando a dança serve como pano de fundo para a recitação de uma poesia; e (viii) a presença, a tensão emocional projetada através da sensualidade ou de um comportamento animal.

Hanna ressalta que a dança pode significar enquanto um signo, mas pode também representar uma sensação, ou ser instrumental quando usada para atingir certo estado de espírito. Porém, a questão de representação ou de realidade é algo que está ligado à crença de quem vê ou de quem dança (1990, p.365). Ou seja, ainda que uma técnica, como a contemporânea, não tenha um referente explícito, o público pode encontrar um significado que não corresponde de maneira alguma à intenção do coreógrafo. O uso cotidiano do corpo em dada cultura irá propiciar o uso ou 
interpretação de determinado movimento. A forma de utilização da tabela formada pelos seis dispositivos que encapsulam o significado e pelas oito esferas de interpretação, no entanto, não está explicitada no capítulo referido, e sua utilização, presente em Hanna 1987 [1979] para uma dança do povo Ubakala, não prevê uma separação do movimento técnico e do gestual, não sendo possível estabelecer uma semântica exclusiva da técnica através da tabela proposta.

\subsubsection{Nível gestual}

Separado o movimento técnico, que inclui uma gestualidade prevista pelo código estabelecido como técnica clássica, como exposta acima, é possível analisar o elemento gestual que se aproxima mais da gestualidade a que estamos acostumados em nossas interações cotidianas. Essa gestualidade parece contribuir para a narrativa desenvolvida no balé, na medida em que possibilita sua interpretação por meio de uma categorização presente na vida fora do teatro.

Kendon (2004), nos estudos dos gestos que acompanham a fala, coloca a questão de suas diferentes possibilidades de categorização, seja por critérios formais, seja por critérios funcionais, ou ainda pragmáticos, e apresenta a solução de considerar aspectos que sejam pertinentes ao objetivo do trabalho a ser desenvolvido. Esta dissertação realiza a categorização dos gestos a partir de critérios fundamentalmente formais, mas, sem dúvida, critérios funcionais e pragmáticos também acabam influenciando a classificação.

Com relação à classificação dos gestos, parto da proposta de McNeill (1992) para os gestos que acompanham a fala - dêiticos, icônicos, metafóricos, coesivos e batidas - adaptando-a ao discurso dançado, e utilizo-me da subdivisão em hipoícones concebida por Peirce e incorporada aos estudos do gesto por Mittelberg (2006). A categorização aqui apresentada não parte de categorias clássicas, mas sim de categorias organizadas em torno de um protótipo, como sugerido pela Linguística Cognitiva ${ }^{29}$. O próprio McNeill, em 2005, prefere usar o termo dimensão ao termo categoria, justamente porque os limites categóricos, no sentido tradicional do termo, são

\footnotetext{
${ }^{29}$ O processo de categorização, neste trabalho, é entendido no sentido do estabelecimento de categorias radiais, propostas por Lakoff (1987) e baseadas no trabalho sobre protótipos desenvolvido por Eleanor Rosch, durante os anos setenta do século XX. A partir de um núcleo estabelecido pela experiência (protótipo), extensões metafóricas, metonímicas, relações de esquemas imagéticos (entre outras possibilidades) ligam-se a outros membros, que exibem uma maior ou menor proximidade em relação a ele, criando uma categoria composta de elementos com diferentes graus de pertencimento.
} 
problemáticos para o estudo do gesto. No mesmo sentido, Peirce (1903) ressalta que não há signos puros, pois há mais de uma dimensão semiótica envolvida na construção do signo. Dessa forma, uma dimensão pode ser mais saliente que as outras. A proposta de que o contexto e a intenção comunicativa determinam a dimensão semiótica que, em um signo, tem precedência sobre as outras (Mittelberg 2006, p. 37) foi, então, contemplada para a classificação dos gestos. A opção pela inclusão da divisão de hipoícones deveuse ao caráter icônico da dança, ressaltado por Hanna (1979).

\subsubsection{Categorização de gestos que acompanham a fala}

Considerando os gestos manuais que acompanham a fala, McNeill estabelece as seguintes categorias de gesto:

(i) icônicos: gestos que representam um referente concreto, de acordo com a saliência atribuída a ele pela comunidade, fortemente ligado ao conteúdo semântico do discurso. No exemplo abaixo, apresentado por McNeill (1992, p. 12), retirado de uma narrativa, o falante produz o gesto com a mão direita ao mesmo tempo em que explica “...e ele dobrou ela pra trás", referindo-se a uma árvore que sofre essa ação. O discurso não traz o modo como a árvore foi dobrada: se com o corpo ou com as duas mãos ou com uma mão apenas; é o gesto que acrescenta essa informação à fala.

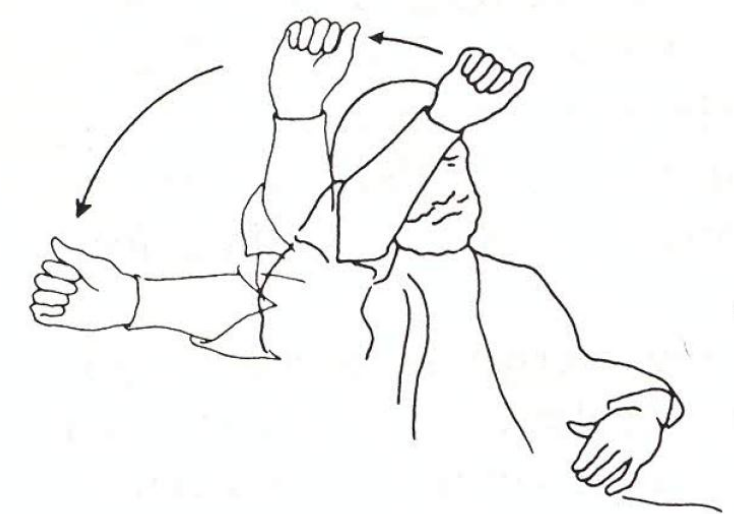

Figura 20. Exemplo de gesto icônico, conforme McNeill (1992, p. 12).

(ii) metafóricos: fornecem imagens concretas a ideias ou conceitos abstratos. No exemplo abaixo, retirado de Mittelberg (2006, p. 246), a professora em uma aula de gramática está explicando o conceito de sentença. A mão direita aberta com a palma para cima oferece suporte ao objeto 'sentença' que ela 'mostra' aos alunos, ou seja, para ela o conceito abstrato de sentença é apresentado aos alunos como um objeto a ser observado concretamente para ser estudado. 


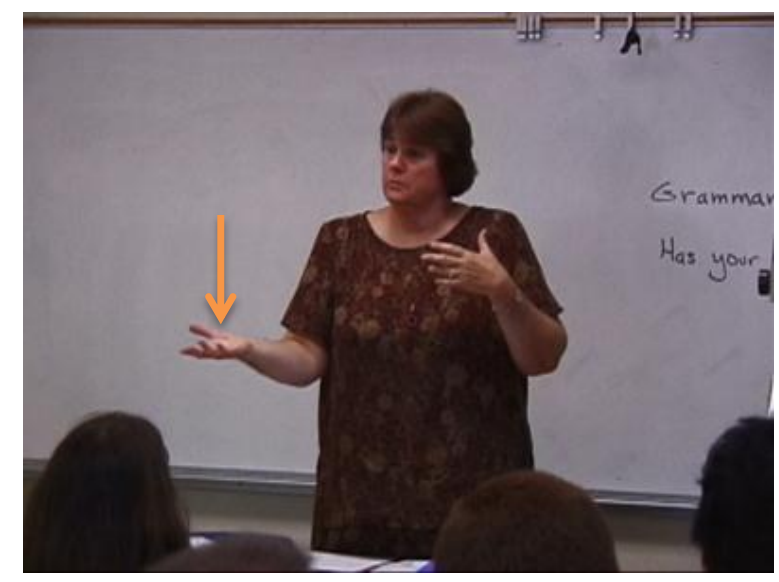

Figura 21. Exemplo de gesto metafórico, retirado de Mittelberg (2006, p. 246) ${ }^{30}$.

(iii) dêiticos: usados para apontar os elementos do discurso interessantes à atenção conjunta, podendo ou não estar fisicamente presentes. Abaixo, temos o exemplo de um homem que aponta para seu(s) interlocutor(es) com a mão direita aberta, dedos estendidos, palma virada para cima em posição diagonal.

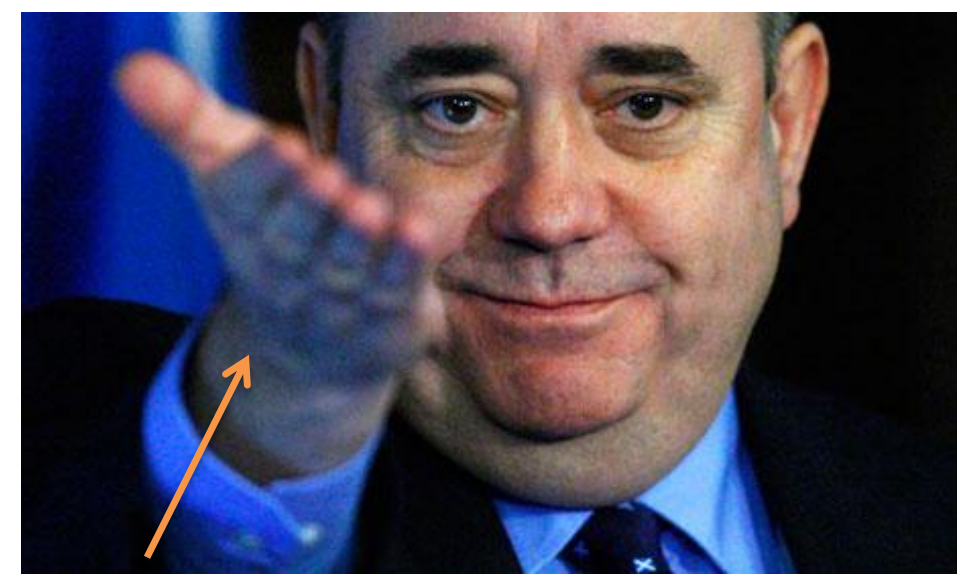

Figura 22. Exemplo de gesto dêitico ${ }^{31}$

${ }^{30} \mathrm{O}$ exemplo foi retirado de Mittelberg, Irene (2006). Metaphor and Metonymy in Language and Gesture: Discourse Evidence for Multimodal Models of Grammar. Ph.D. Dissertation, Cornell University. Published online. Ann Arbor, MI: UMI.

${ }^{31}$ O exemplo foi retirado de

http://images.google.com.br/imgres?q=gestures+around+the+world\&start=336\&num=10\&hl=ptBR\&biw $=1160 \&$ bih=606\&tbm=isch\&tbnid=t4wSQPLDxgeQCM:\&imgrefurl=http://www.guardian.co.uk/comme ntisfree/2012/mar/07/scottish-referendum-datematters\&docid=qJ885qZL8fTCxM\&imgurl=http://static.guim.co.uk/sysimages/Guardian/Pix/pictures/20 12/3/7/1331146616543/Alex-Salmond-gestures-to-007.jpg \&w=460\&h=276\&ei=LXmQUJyFN8Xd0QGXyIG4Bw\&zoom=1\&iact=hc\&vpx=340\&vpy=24\& dur=4802\&hovh $=174 \&$ hovw $=290 \& \mathrm{tx}=158 \& \mathrm{ty}=194 \&$ sig $=116665015173323068710 \&$ page $=17 \& \mathrm{tbnh}=12$ $\underline{4 \& \text { tbnw }=194 \& \text { ndsp }=20 \& v e d=1 t: 429, \mathrm{i}: 130}$ 
(iv) batidas: marcam o ritmo da fala, além de poder indicar a relevância de um item lexical ou uma sentença para o desenvolvimento do discurso, por exemplo, quando ocorrem no momento de introdução de um novo referente ou de novas personagens, quando o locutor sumariza uma ação, na introdução de novos temas, etc. Esse gesto é muito utilizado por políticos em discursos durante campanhas eleitorais. No caso, o exemplo a seguir é o do candidato à Prefeitura de São Paulo, José Serra, durante debate televisivo. O gesto, realizado com a mão direita, com a ponta dos dedos indicador e polegar unidos e os outros dedos flexionados sobre a palma da mão, com o punho flexionado e direção ao torso da mão e a palma para frente, foi bastante usado para pontuar o discurso, não apenas ritmicamente, mas também para chamar a atenção dos interlocutores para os pontos que ele considerava relevantes no discurso.

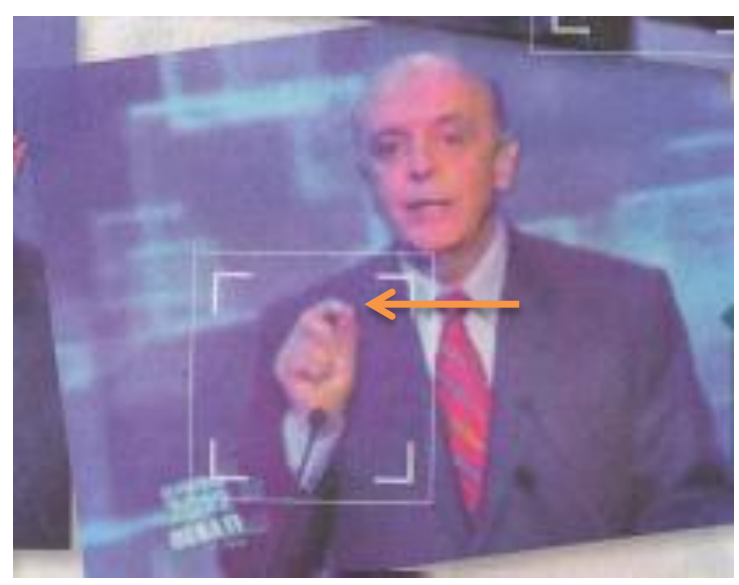

Figura 23. Exemplo de batida ${ }^{32}$

(v) coesivos: gestos discursivos que servem para unir partes tematicamente convergentes, mas temporalmente separadas no discurso. No exemplo abaixo, retirado de McNeill (1992, p. 17), a mulher diz “... a rede de cabos que segura os bondes”, acompanhado do gesto (a); depois ela fala "você sabe, o sistema de ônibus elétrico", junto com o gesto (b); e retoma o que vinha dizendo anteriormente "certo, e há toda uma rede desses fios...", ao mesmo tempo em que produz (c), que vem a ser uma retomada do gesto (a).

\footnotetext{
${ }^{32}$ O exemplo foi retirado do jornal Folha de São Paulo, Caderno Eleições, de 26 de outubro de 2012.
} 

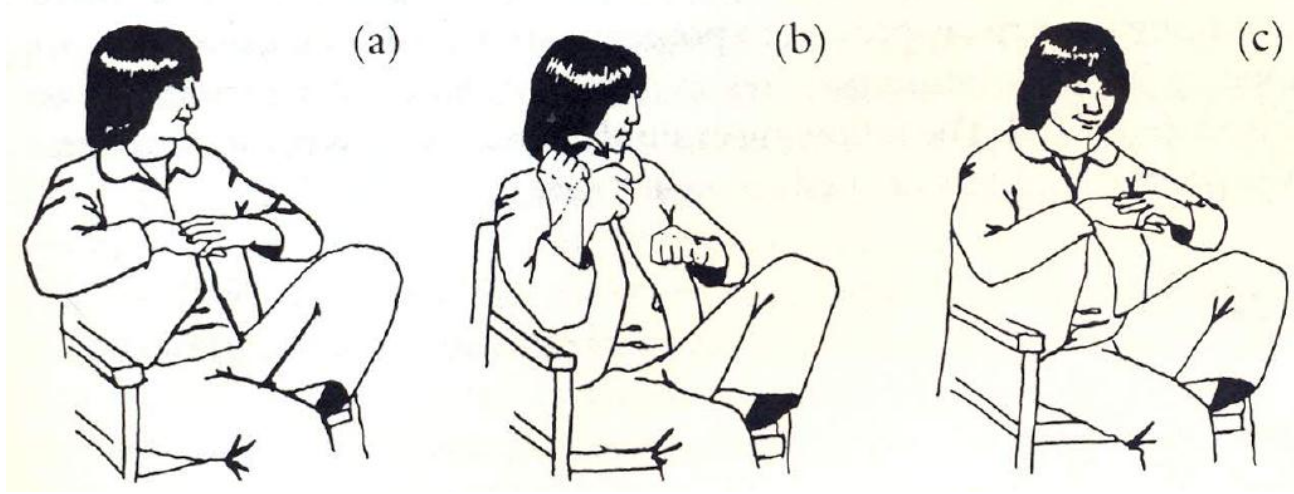

Figura 24. Exemplo de gesto coesivo, retirado de McNeill (1992, p. 17).

Mittelberg (2006), também trabalhando com gestos que acompanham a fala, incorpora o conceito de hipoícone, proposto por Peirce $(1902)^{33}$. O conceito de hipoícone é proveniente da categorização dos signos em ícone, índice e símbolo. $\mathrm{O}$ ícone caracteriza-se por assemelhar-se a um objeto, existente ou não. O índice é um signo que é afetado pelo objeto denotado. O símbolo é uma convencionalização para referência a um objeto (Peirce 1902, p.2).

Farias e Queiróz (2006, p.291) propõem o estabelecimento de uma diferença entre ícones e signos icônicos: os primeiros são possibilidades lógicas e os últimos, as instanciações do ícone, participantes de relações sígnicas existentes por similaridade. Esses ícones instanciados, segundo Farias e Queiróz, são chamados hipoícones e dividem-se em:

i) imagens, ou qualidades imediatas, aparentes ou superficiais, por exemplo, na representação de um ser humano em um pictograma, que

\footnotetext{
${ }^{33}$ Roman Jakobson foi um dos responsáveis por trazer as noções da teoria semiótica de Peirce para a linguística. Em um de seus textos seminais - A linguagem comum dos linguistas e antropólogos Jakobson escreve: "Em face da iminente tarefa de analisar e comparar os diferentes sistemas semiológicos, devemos nos lembrar não só da divisa de F. de Saussure de que a Linguística é parte integrante da ciência dos signos, mas também, e antes de tudo, da obra monumental de seu eminente contemporâneo, um dos maiores precursores da análise estrutural linguística, Charles Sanders Peirce. Peirce não só estabeleceu a necessidade da Semiótica como esboçou-lhe também as grandes linhas. Quando se estudarem cuidadosamente as ideias de Peirce a respeito das teorias dos signos, dos signos linguísticos em particular, ver-se-á o precioso auxílio que trazem às pesquisas sobre as relações entre a linguagem e os outros sistemas de signos. Seremos então capazes de discernir os traços próprios do signo linguístico.", em Jakobson, Roman. 1969. "A Linguagem Comum Dos Linguistas e Dos Antropólogos.” In Linguística e Comunicação, Roman Jakobson. São Paulo: Cultrix, p. 17-18.
} 
reproduz esquematicamente as partes que compõem um corpo humano, como é possível observar a partir da foto do homem, conforme figura 4 de Farias e Queiróz (2006).
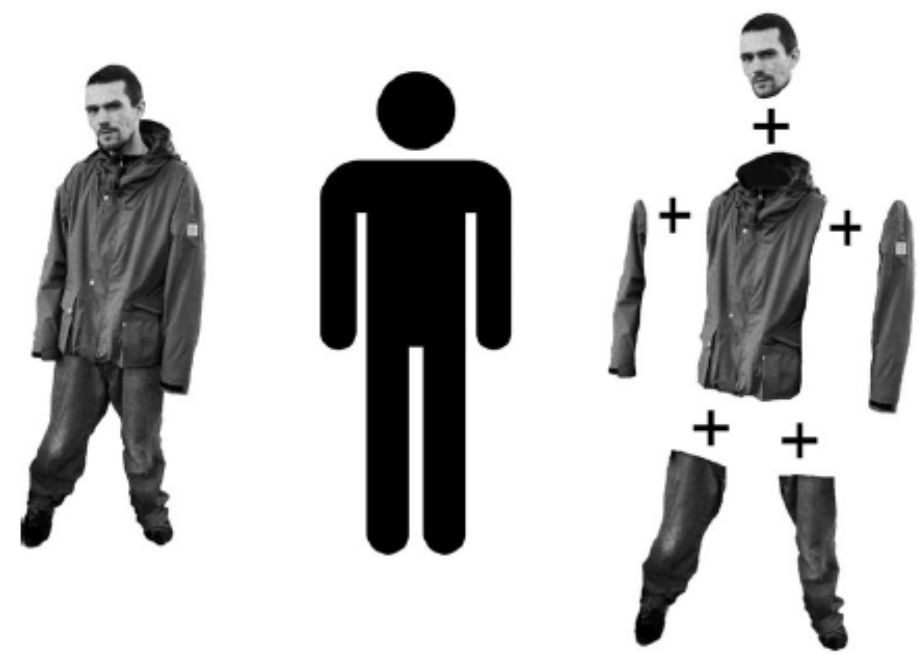

Figura 25. Exemplo de hipoícone imagético, retirado de Farias e Queiróz (2006, p.296).

ii) diagramas, ou semelhança estrutural com o objeto, por exemplo, a semelhança do pictograma com um homem e uma cesta de lixo para ensejar a representação do ato de jogar algo no lixo, conforme figura 3 (Farias e Queiróz 2006).

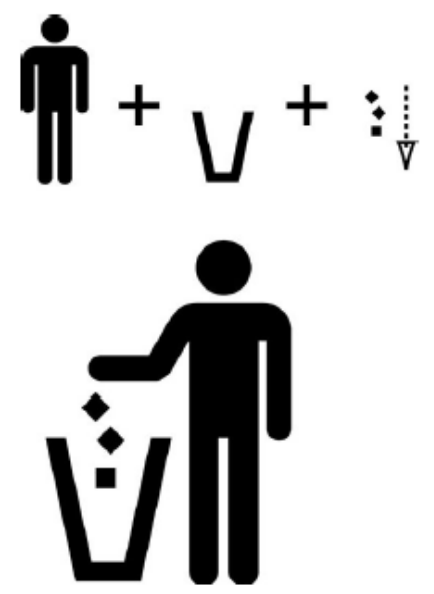

Figura 26. Exemplo de hipoícone diagramático, conforme Farias e Queiróz (2006, p. 295).

iii) metáforas, ícones instanciados por hábitos, convenções ou leis gerais, representado pelo exemplo abaixo de um pictograma metafórico "vamos acabar com o nazismo", reproduzindo a figura 2 de Farias e Queiróz (2006). Nele observa-se a 
dependência da interpretação do diagrama jogar no lixo e do reconhecimento da suástica como símbolo do nazismo.

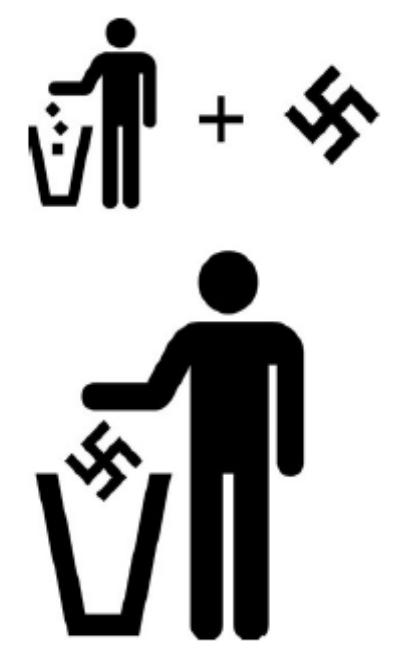

Figura 27. Exemplo de hipoícone metafórico, retirado de Farias e Queiróz (2006, p. 295).

Os hipoícones são menos mediados por outros signos para sua interpretação, ou seja, apelam mais diretamente aos sentidos, estabelecendo uma relação mais direta entre objeto e signo.

A tipologia de gestos apresentada baseia-se em aspectos formais, ou seja, leva em conta a posição dos articuladores (no caso, mãos e braços) no desenvolvimento do gesto. Isso significa que os aspectos observados são, entre outros, a orientação da palma das mãos, a posição das mãos com relação ao corpo do gesticulador, a configuração da mão durante o gesto. Este trabalho tem como base esse tipo de classificação formal, ainda que, como mencionado anteriormente, outras possibilidades existam, baseadas, por exemplo, no aspecto da funcionalidade do gesto, que classifica os gestos de acordo com a função a que ele está servindo no momento da interação ${ }^{34}$.

\footnotetext{
${ }^{34}$ Streeck (2009) propõe uma classificação mais funcional do gesto, apresentando as funções de indicar, descrever e simbolizar. A indicação pode se dar tanto por gestos de orientação, no mundo "ao alcance da mão" ou "ao alcance da vista", como pela direção do olhar. Através dos gestos de orientação os interlocutores estabelecem "o elemento do mundo à mão que interessa ao projeto em curso, seja ele algo específico, uma parte, o todo, uma coleção ou um conjunto" (p. 66). Dessa forma, os gestos podem apontar para traços de um objeto complexo não acessíveis ao interlocutor, sugerir ações possíveis com esse objeto no contexto, mostrar a saliência de partes de um objeto complexo, entre outras funções. Usado para indicar referentes presentes no contexto, o olhar também pode se dirigir a gestos descritivos, apresentando-os e mantendo, de certa forma, a função referencial, já que aponta para algo relevante ou saliente para o projeto em curso. A descrição gestual aparentemente é dependente de uma estrutura
} 


\subsubsection{Uma proposta de classificação}

Minha proposta de classificação toma aspectos formais presentes na classificação de McNeill (1992), incorporando aspectos semióticos específicos da iconicidade, presentes em Mittelberg (2006), para aplicá-los à análise do discurso dançado. A opção por aspectos formais para tipificar gestos que acompanham a dança se deve ao fato de que, em dança, independentemente do estilo, os corpos comunicam desenhando formas no espaço, através de movimentos técnicos, de gestos, de desenhos coreográficos. A iconicidade se torna central nesse processo.

Para Mittelberg (2006), a iconicidade é o modo semiótico dominante na produção de gestos que representam tanto o concreto quanto o abstrato (p.179). Ela incorpora os modos icônicos à categoria dos gestos metafóricos, mantendo a nomenclatura de Peirce: iconicidade imagética, iconicidade diagramática e iconicidade metafórica. Ainda que os ícones sejam fundamentais para a comunicação de ideias, como colocado por Peirce (CP 2.278) ${ }^{35}$, também os índices, que apontam para objetos no mundo extra-linguístico, são basilares no processo comunicativo (Danaher 1998, p.191). Com relação aos gestos, assim como na linguagem, não apenas os índices, mas também os ícones proveem a ancoragem do evento no momento da enunciação (Mittelberg 2006, pp.178-179). Segundo Peirce (1932 [2010]), somente através dos ícones conseguimos comunicar uma ideia diretamente, e a comunicação indireta

específica que prevê atenção conjunta. Há uma distinção entre gestos miméticos e gestos de interpretação em termos de visibilidade, isto é, a mimese é produzida para ser vista como representação de ações, enquanto os gestos de interpretação reproduzem um esquema conceitualizado a partir de uma interpretação da ação. Como colocado por Streeck, "gestos que retratam ações humanas têm uma lógica simples: o corpo produz um esquema motor conhecido, tornando-o uma versão abstrata de um ato cotidiano" (p.144). Diferentemente de outros gestos descritivos, gestos que retratam ações humanas organizam "uma experiência encenando, exagerando, embelezando e modulando padrões feitos da mesma matéria que o denotado" (p.146). Essa experiência encenada, exagerada, embelezada é algo bastante comum em narrativas dançadas. Streeck prevê ainda a categoria de gestos usados para 'simbolizar'. Na verdade, são gestos imagéticos que não retratam, mas conceitualizam um objeto ou evento. Emoções, por exemplo, são processos internos, mas podem ser representados como sendo eventos no espaço. Ou seja, não há obrigatoriedade de existência real para que seja possível uma representação gestual, mas deve haver a conceitualização do abstrato enquanto objeto para que ele possa ser representado como tal. A conceitualização gestual recebe de Streeck o nome de cepção e é "o construal de conteúdo por meio de esquemas manuais para fins de comunicação” (p.161-162), ou seja, cepção é a forma escolhida a partir do modo como concebemos conteúdos semânticos que queremos comunicar. Assim, a distinção entre ato prático e gesto reside na possibilidade que este tem de elaborar signos corpóreos que, indicando, descrevendo ou simbolizando o significado, são interpretados como signos.

${ }^{35}$ Esta referência de Peirce encontra-se na página 64, na tradução de José Teixeira Coelho, publicada pela Editora Perspectiva em 2010. 
também está baseada em ícones. A consequência lógica, apresentada por Peirce, é a de que toda asserção deve conter um ícone ou conjunto de ícones. Ele ressalta que uma importante propriedade dos ícones é permitir que, através de sua observação, outras verdades relativas do objeto possam ser reveladas (Peirce 1932 [2010], p. 65). Os ícones são a instanciação dos conceitos a que nos referimos quando nos comunicamos. Em dança, por exemplo, o corpo e as formas por ele produzidas são responsáveis por trazer os conceitos que subjazem a comunicação para o momento da enunciação. Por sua natureza de relação entre entidades, o índice compartilha propriedades com os diagramas, que são diretamente relacionados com a espacialização de informações abstratas e a espacialização de estruturas. A categorização proposta por Mittelberg inclui, então, através da subdivisão da iconicidade, os elementos que ancoram os gestos abstratos na enunciação.

Diferentemente de Mittelberg, que incorpora a divisão dos hipoícones na categoria de gestos metafóricos, proponho incorporá-los na categoria de gestos icônicos, mantendo a subdivisão dos ícones como proposto por Peirce, entendendo que os gestos são instanciações de caráter icônico, pois estão ligados ao aspecto visual. Além disso, conta ainda para essa opção o fato de a iconicidade ser reconhecidamente prevalente na dança, e as possibilidades de extensão metafórica serem inerentes à conceitualização humana, segundo Lakoff e Johnson $1980^{36}$. Incorporo os modos de iconicidade aos gestos icônicos através de gestos icônicos imagéticos, icônicos diagramáticos e icônicos metafóricos, ampliando suas possibilidades com relação à categorização de McNeill (1992). Dessa forma, mantenho a iconicidade presente nos gestos metafóricos e ganho

\footnotetext{
${ }^{36}$ Lakoff e Johnson (1980) propõem que metáforas são o entendimento e a experiência de uma coisa através de propriedades de outra coisa. Assim, buscamos apreender e compartilhar conceitos abstratos através de conceitos mais concretos, que emergem como fruto dos processos de interação com outros seres no mundo. As metáforas conceituais tornam-se viáveis na linguagem porque são parte da fundação de nosso sistema conceitual. Esquemas imagéticos, abstrações elaboradas a partir de nossas experiências sensório-motoras (Johnson 1987) e de dinâmica de forças (Talmy 1988), tornam possível o mapeamento de um esquema no domínio-fonte em outro esquema no domínio-alvo, adicionando-lhe elementos trazidos da fonte (Lakoff e Johnson 1980). O domínio-fonte provê os esquemas necessários para o entendimento do domínio-alvo. Em outras palavras, buscamos entender o domínio-alvo através do domínio-fonte. Por exemplo, valemo-nos de nossa orientação espacial para tratar de certos conceitos abstratos. A partir de nossa experiência corporal, estabelecemos distinções orientacionais entre os conceitos de baixo e cima, dentro e fora, frente e trás, etc. Para expressarmos os conceitos abstratos de alegria e tristeza, atribuímos a eles posições em uma escala vertical, que resultam nas metáforas conceituais ALEGRIA É PARA CIMA e TRISTEZA É PARA BAIXO. A noção abstrata de intensificação também é colocada numa escala vertical, conceitualizada como MAIS É PARA CIMA. A evidência para a existência dessas metáforas conceituais como formas de conceitualização de noções abstratas veio de sua presença massiva no uso cotidiano de várias línguas.
} 
uma dimensão relacional através da iconicidade diagramática. Essa distinção de aplicação do conceito de hipoícone talvez se deva à distinção da análise de gestos que acompanham a fala e de gestos que acompanham a dança. Na dança, o corpo representa conceitos através da forma, ou seja, a significação fica baseada na semelhança formal atingida para a conceitualização do concreto e do abstrato. Não há apoio de um signo linguístico para aproximação do conceito, não havendo, portanto, a possibilidade de referência a signos simbólicos para a análise dos gestos. Os critérios para uma possível categorização apoiam-se grandemente, mas não exclusivamente, em aspectos formais. O que caracteriza o ícone é sua semelhança com o objeto ao qual se refere. Com a incorporação dos modos de iconicidade ao seu espectro, emergem novas possibilidades de representação e interpretação tanto de conceitos concretos quanto de conceitos abstratos, além da dimensão relacional através da iconicidade diagramática.

Além disso, gestos têm dimensões multifuncionais, o que significa que um mesmo gesto como o de segurar uma caixa pode representar o ato de segurar uma caixa, de fato, ou pode representar um conceito abstrato como algo que pode ser contido em um espaço determinado, como o espaço de uma caixa. No caso das batidas, além de marcar o ritmo da fala, elas têm uma função indexical com relação às palavras sobre as quais recaem. A interpretação do gesto que acompanha a fala recai sobre as palavras produzidas simultaneamente com os gestos. Em dança, esse recurso não está disponível. A possibilidade de lidar com as ambiguidades dos gestos em dança é dada pela sua inserção em um contexto narrativo, de modo a que eles sejam interpretados com relação a movimentos realizados anterior e posteriormente.

Apresento a seguir, a Tabela 2, com as classificações de McNeill, de Mittelberg e a classificação por mim utilizada. 
Tabela 2 Categorização de gestos que acompanham a fala (McNeill 1992) e gestos que acompanham o discurso dançado

\begin{tabular}{lll}
\hline McNeill & Mittelberg & Discurso dançado \\
\hline dêiticos & dêiticos/metonímicos & dêiticos \\
icônicos & icônicos imagéticos \\
& icônicos diagramáticos \\
metafóricos & metafóricos & icônicos metafóricos \\
& $\bullet \quad$ iconicidade imagética & \\
& $\bullet \quad$ iconicidade diagramática \\
& $\bullet$ iconicidade metafórica & \\
& & coesivos \\
coesivos & & batidas \\
batidas & & \\
\hline
\end{tabular}

Em dança, os gestos dêiticos correspondem aos gestos de apontamento, que indicam os referentes do discurso, sejam eles parte do texto ou do contexto de enunciação. Além do apontamento manual, outras partes do corpo podem fazer essa indicação, como olhos, cabeça, cotovelo, queixo, bem como a posição do corpo do intérprete.

Gestos icônicos imagéticos são os gestos de apreensão direta, que mimetizam, as características físicas e as ações dos referentes do discurso. Eles são bastante frequentes nas pantomimas.

Gestos icônicos diagramáticos, por reproduzirem apenas uma parte da estrutura do objeto representado, apelam para uma conceitualização de relação entre parte e todo, ou seja, estão sujeitos a um processo de metonímia interna, termo cunhado por Jakobson para se referir à relação de sinédoque (Mittelberg 2006). Deixam de ser uma apreensão tão direta quanto a de uma imagem.

Já os gestos icônicos metafóricos correspondem aos gestos metafóricos da classificação de McNeill (1992). São gestos que representam objetos e referentes abstratos. Esses gestos irão requerer do intérprete o mapeamento de um elemento pertencente a um domínio mais abstrato em termos de um elemento de outro domínio mais concreto ${ }^{37}$. No caso da dança, esse mapeamento se dará através da iconicidade.

${ }^{37}$ Nesse ponto, é possível aproximar o gesto metafórico da cepção, ou gesto de conceitualização, conforme proposta de Streeck (brevemente apresentada na nota 34), já que ambos informam acerca das concepções do gesticulador. 
As ocorrências de batidas na gestualidade que acompanha a dança correspondem à função de acompanhamento do ritmo do discurso oral, enfatizando um movimento que não pertence à técnica através da repetição. Conferindo modulações à gestualidade, as batidas fazem o acompanhamento do tempo musical, à semelhança do acompanhamento que oferecem à cadeia de fala do discurso. Os gestos coesivos acabam por fazer um apontamento metadiscursivo, pois assinalam a retomada de um ponto prévio do discurso, mas parecem não trazer forma própria, tomando sua morfologia às outras categorias gestuais, como observado por McNeill (1992, p.18).

Como já mencionado, as categorias, neste trabalho, são difusas, isto é, não têm limites categóricos estanques. Isso se deve a um processo de categorização ligado à proposta de protótipos elaborada por Eleanor Rosch em vários estudos ao longo dos anos setenta do século XX, e incorporada aos estudos linguísticos por George Lakoff ${ }^{38}$. De acordo com achados empíricos, Rosch observou que há o estabelecimento de um membro da categoria como sendo prototípico, e que a categorização é feita com base nos graus de aproximação ou distanciamento desse modelo. Minha hipótese é a de que há um contínuo entre as categorias que proponho, ou seja, gestos mais próximos dos protótipos de uma categoria são icônicos imagéticos, por ter uma interpretação menos mediada; gestos menos próximos do protótipo são icônicos diagramáticos, e necessitam da explicitação da relação para serem interpretados; e gestos mais afastados do protótipo seriam icônicos metafóricos, utilizando um paralelismo para a interpretação, como ilustrado no diagrama abaixo:
imagético
diagramático
metafórico
+ prototípico
- prototípico

\subsubsection{Nível paraquinésico}

O nível paraquinésico está ligado à qualidade do movimento técnico e gestual. Os elementos que compõem esse nível correspondem às dimensões peso - ligada à energia ou força muscular e graus de tensão envolvidos na execução do movimento - e fluência, ligada a aspectos de fluxo e ação, propostas por Laban (1975, p. 54-87), cujos aspectos estão descritos na nota 12 acima. Em sua proposta para o movimento corporal, Sheets-Johnstone (1999) traz as dimensões de amplitude e projeção, que acrescentam outros elementos para a análise do nível paraquinésico. A amplitude é analisada como o

\footnotetext{
${ }^{38}$ Ver nota 29 acima.
} 
espaço preenchido pelo movimento corporal, determinado física, cultural e socialmente; e a projeção, como o controle da quantidade de esforço necessária para a execução de um movimento ${ }^{39}$. Apesar de serem discriminadas em diferentes dimensões, essas qualidades atuam simultaneamente sobre os movimentos. E por serem qualidades de movimento em geral são dimensões presentes tanto nos movimentos correspondentes ao nível técnico, quanto àqueles que se encontram no nível gestual.

Um exemplo de como a paraquinese atua sobre o nível gestual pode ser observado na diferença encontrada em um mesmo gesto realizado por duas intérpretes de Julieta em versões diferentes, como ilustrado abaixo:
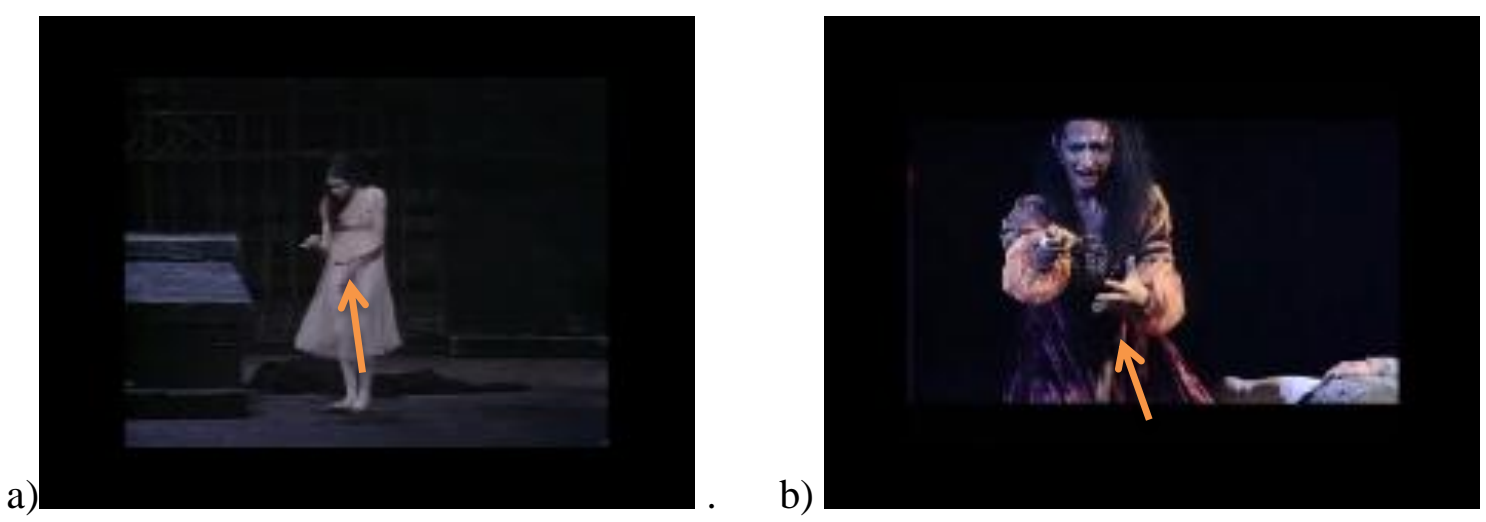

Figura 28. Exemplo de paraquinese em gesto ${ }^{40}$

O gesto realizado com a mão esquerda em (a) é formalmente igual àquele realizado em (b). No entanto, os graus de tensão são bastante diferentes, já que (b) apresenta um grau de tensão muito superior a (a). Há, ainda, diferenças em peso, amplitude e projeção. Em (a), a força muscular empregada para realizar o gesto é normal, a amplitude é menor e a projeção revela maior controle na execução do movimento, já que ele é realizado mais lentamente. Em (b), a força muscular é intensa,

\footnotetext{
${ }^{39} \mathrm{Na}$ proposta original de Sheets-Johnstone há, ainda, a dimensão da linearidade, que corresponde ao percurso do movimento, mas que não caberia como qualidade aplicada sobre o nível técnico, pois é uma dimensão que faz parte da técnica da dança, já que os passos são realizados sempre em relação a uma posição e um percurso no espaço. A dimensão da linearidade também está ligada à relação espacial implicada na realização do movimento, como, por exemplo, a relação entre o torso e os quadris, braços e torso, cabeça e ombros, entre outras, que acontecem simultaneamente quando o corpo se move. Essa também é uma relação que já está presente na técnica de dança, não sendo pertinente, portanto, ao nível paraquinésico. Outra dimensão proposta por Sheets-Johnstone é a da tensão, equivalente a um dos aspectos componentes da dimensão peso de Laban.

${ }^{40}$ A intérprete de (a) é Alessandra Ferri, na versão de Romeu e Julieta criada por Kenneth MacMillan para o The Royal Ballet, enquanto a intérprete de (b) é Monique Loudiere, na versão criado por Rudolf Nureyev para o Ballet de L’Opéra de Paris.
} 
a amplitude é maior e a projeção revela menor controle, pois o movimento é realizado mais rapidamente.

Outro exemplo da atuação da paraquinese, agora sobre o nível técnico, pode ser observado na figura abaixo. As intérpretes femininas executam um arabesque (cf. figura 17), e é sobre ele que a paraquinese vai atuar. Em (a), a amplitude e a projeção da perna que está no ar em arabesque são maiores do que aquelas presentes em (b). Também com relação à tensão há diferenças, já que em (b) o grau de tensão é menor do que aquele presente em (a). Fluência e peso atuam de modo semelhante nas duas versões ${ }^{41}$.
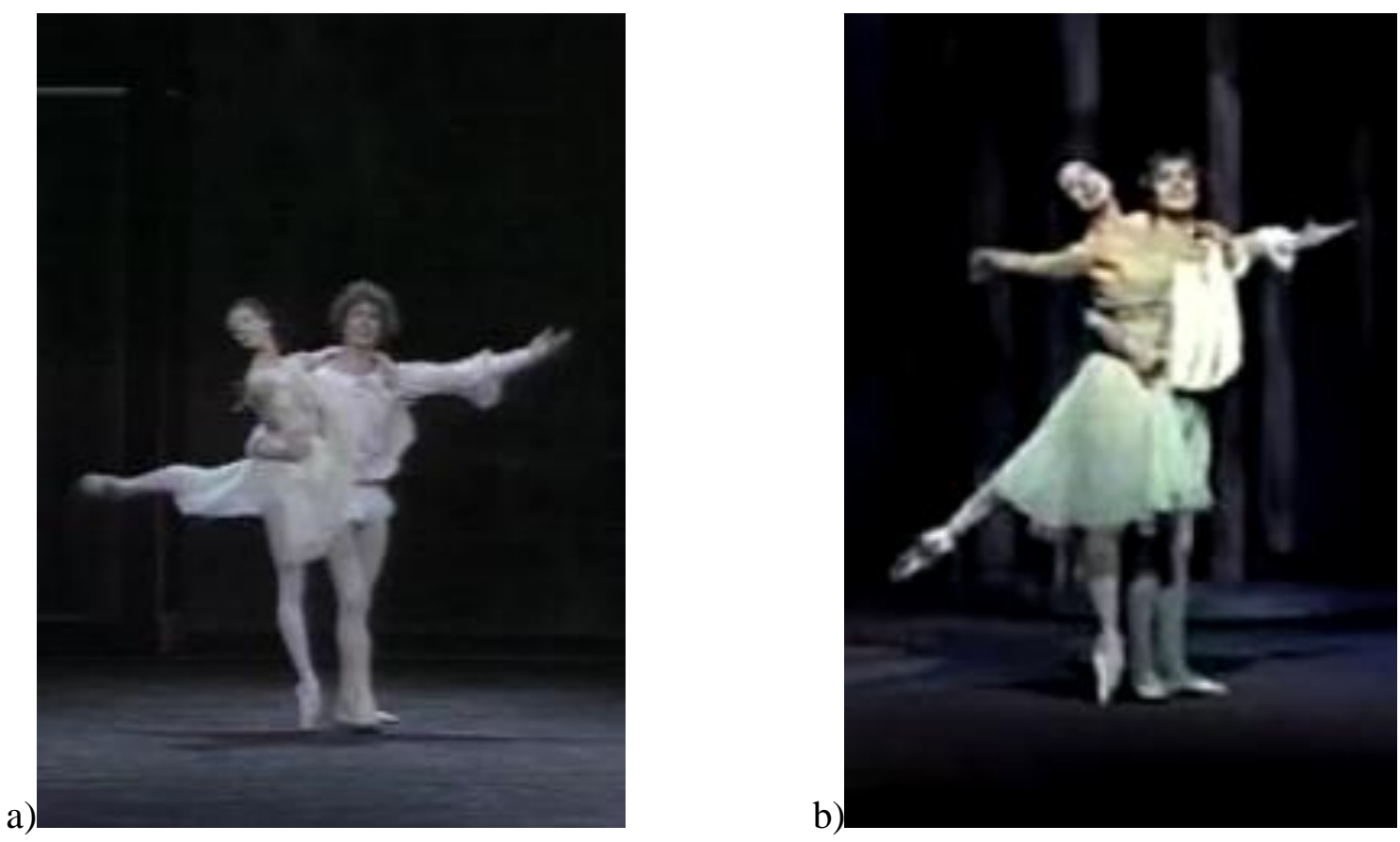

Figura 29. Exemplo de paraquinese no nível técnico ${ }^{42}$

O nível paraquinésico atua simultaneamente sobre os outros dois níveis do discurso dançado. Seu controle está diretamente relacionado ao grau de proficiência do bailarino, pois determina uma parte considerável do significado atribuído aos movimentos, tanto técnicos como gestuais. Um futuro trabalho pode vir a detalhar essa interação, propondo uma forma apropriada para a transcrição dos dados observados.

${ }^{41}$ É necessário levar em consideração que diferentes bailarinos apresentam diferentes características físicas. O exemplo apresentado aqui visa a ressaltar alguns aspectos de paraquinese passíveis de serem demonstrados através de registro fotográfico, já que outros aspectos só podem ser observados no decorrer da realização do movimento. (Nota inserida por sugestão da banca examinadora.)

${ }^{42}$ A intérprete de (a) é Alessandra Ferri, na versão de Romeu e Julieta criada por Kenneth MacMillan para o The Royal Ballet, encenada em 1984, enquanto a intérprete de (b) é Margot Fonteyn, na mesma versão, encenada em 1965. 


\section{Capítulo 2 Metodologia}

\subsection{Materiais}

O material escolhido para a análise de gestos em dança foram os vídeos de duas versões coreografadas da peça Romeu e Julieta de William Shakespeare, uma criada por Sir Kenneth MacMillan, para o The Royal Ballet, interpretada por Alessandra Ferri e Wayne Eagling, em 1984 (versão inglesa), e outra coreografada por Rudolf Nureyev, para o Ballet de L'Opéra de Paris, interpretada por Monique Lourdières e Manuel Legris, em 1995 (versão francesa) .

As duas versões baseiam-se no escore musical de Sergei Prokofiev, primeiramente apresentado na forma de concerto em Moscou, em outubro de 1935, tendo sido utilizado para ballet pela primeira vez em 1938, na então Checoslovaquia. Em 1940, Leonid Lavrovsky coreografou sua versão para a companhia do Teatro Kirov de Ópera e Ballet, em Leningrado. Acerca de sua concepção, o próprio coreógrafo comenta que a intensidade das paixões elaboradas por Shakespeare pede uma fusão entre dança e mímica. Essa fusão, porém, não deve ser trivial, composta de gestos simplesmente imitativos, mas tem que tornar-se a expressão das personagens, emoções e paixões através dos movimentos corporais (Balanchine \& Mason 1954 [1989]).

A versão de MacMillan, originalmente encenada em 1965, teve influência da versão criada por John Cranko para o Ballet Stuttgart ${ }^{43}$. O trabalho rompeu com os liames da dança clássica de então ao apresentar movimentos não-técnicos em um trabalho clássico. Isso permitiu que a dança emergisse de ações naturais, sem as pausas de final de cena para aplausos, ou os canhões de luz acompanhando as entradas de cena das personagens principais, comuns às encenações clássicas até então. Outra influência reconhecida pelo coreógrafo foi a versão de Franco Zefirelli para o teatro Old Vic, em 1960. Diferentemente do final previsto na tragédia shakespeariana, a versão de MacMillan termina com as cortinas se fechando sem a reconciliação das famílias Montéquio e Capuleto.

\footnotetext{
${ }^{43}$ As referências ao processo criativo de MacMillan foram obtidas em Balanchine \& Mason 1954 [1989] e nos sítios http://www.kennethmacmillan.com/ballets/all-works/1960-1966/romeo-and-juliet.html e http://exeuntmagazine.com/reviews/romeo-and-juliet-2/.
} 
Rudolf Nureyev, intérprete de Romeu na estreia da coreografia de MacMillan, cria sua versão em 1977 para o London Festival Ballet ${ }^{44}$. Da versão de John Cranko, ele retém o retrato fiel da renascença italiana, de acordo com Josseline Le Bourhis. O coreógrafo assume ainda a influência da versão filmada de Franco Zefirelli no que tange à fidelidade ao texto de Shakespeare. De Kenneth MacMillan, ele traz aspectos de Julieta, como sua inabalável determinação para resistir ao destino, exacerbando-os ainda mais. Sua versão é considerada a mais dramática e a mais difícil tecnicamente dentre as coreografias elaboradas sobre a trama shakesperiana.

A escolha da coreografia deveu-se ao fato de não apenas basear-se em texto dramático de narrativa bastante conhecida, com diferentes versões gravadas disponibilizadas favorecendo a acessibilidade ao material, mas também por utilizar a técnica de dança clássica em sua execução. A técnica clássica, diferentemente da dança moderna, mantém uma divisão mais clara entre gestos convencionais, estabelecidos como parte da técnica de dança, e gestos expressivos, mais próximos de uma interpretação naturalista, ou seja, mais próximos dos gestos utilizados cotidianamente. A dança moderna, ao romper com os liames da tradição clássica, utiliza-se de elementos de gestualidade de maneira mais abstrata, incorporando-os eventualmente ao seu escopo técnico, algo que poderia dificultar uma primeira aproximação descritiva. A escolha deveu-se, também, ao fato de eu possuir formação na técnica clássica, o que facilita o reconhecimento da distinção entre movimentos técnicos e gestualidade.

Retirado da coreografia de Kenneth MacMillan, o principal trecho escolhido para ser descrito e analisado foi uma parte da cena do balcão, em que Romeu, depois de ter encontrado e dançado com Julieta no baile de máscaras na casa dos Capuleto, volta para se declarar à amada. Quando Romeu chega à cena, encontra Julieta, na sacada, a divagar sobre o encontro no baile. Ele a convida para descer ao pátio e lá eles declaram seu amor um pelo outro. Para ilustrar a relação entre técnica e gesto, foram observados outros trechos da coreografia de MacMillan e outra versão da cena do balcão da coreografia de MacMillan, desta vez na interpretação de Margot Fonteyn e Rudolf Nureyev.

44 As referências ao processo criativo de Nureyev foram obtidas nos sítios http://www.culturekiosque.com/dance/reviews/rjulnur_pbocca613.html e http://www.nureyev.org/rudolfnureyev-choreographies/romeo-and-juliet-rudolf-nureyev. 
Optei, também, pela seleção de parte de outra cena para verificar a pertinência das categorias observadas na cena acima descrita. A cena escolhida para servir de controle foi a cena final, a partir do despertar de Julieta, nas versões inglesa e francesa. Ao acordar do sono induzido pela poção obtida junto a Frei Lourenço, Julieta percorre a câmara mortuária buscando reconhecer o entorno. Depois de encontrar o corpo de Paris, morto por Romeu em um momento anterior da cena, ela acaba deparando com o corpo de Romeu. Ao abraçá-lo e prantear sua morte, Julieta percebe a adaga ao lado do corpo do amante. Em desespero, acaba por utilizá-la para dar cabo da própria vida.

\subsection{Métodos}

\subsubsection{Programas de edição e de transcrição}

A mídia de vídeo foi convertida para arquivo wmv e editada no programa Windows Movie Maker para possibilitar sua inserção no programa ELAN (EUDICO Language Annotator) (versão 4.1.1), desenvolvido pelo Instituto Max Planck de Psicolinguística em Nijmegen, Holanda. Esse programa tem sido utilizado na transcrição de dados linguísticos, inclusive daqueles de línguas de sinais. Ele possibilita a anotação de gestos de modo bastante detalhado, em linhas chamadas trilhas, que podem ser criadas para a transcrição de cada elemento gestual em separado, como, por exemplo, para descrever o movimento de mão direita, de mão esquerda, de olhos, de sobrancelhas, de boca, etc, de modo simultâneo à visualização do material filmado. Como é possível observar nas figuras abaixo, a barra vermelha (apontada pela seta laranja) indica o ponto da transcrição a que a imagem se refere. Quando a observação inclui dois bailarinos, as trilhas são duplicadas para ser possível a anotação dos gestos de ambos. Dessa forma, transcrição e vídeo são mantidos em um mesmo arquivo, facilitando tanto o processo de anotação quanto o processo de consulta aos dados. 


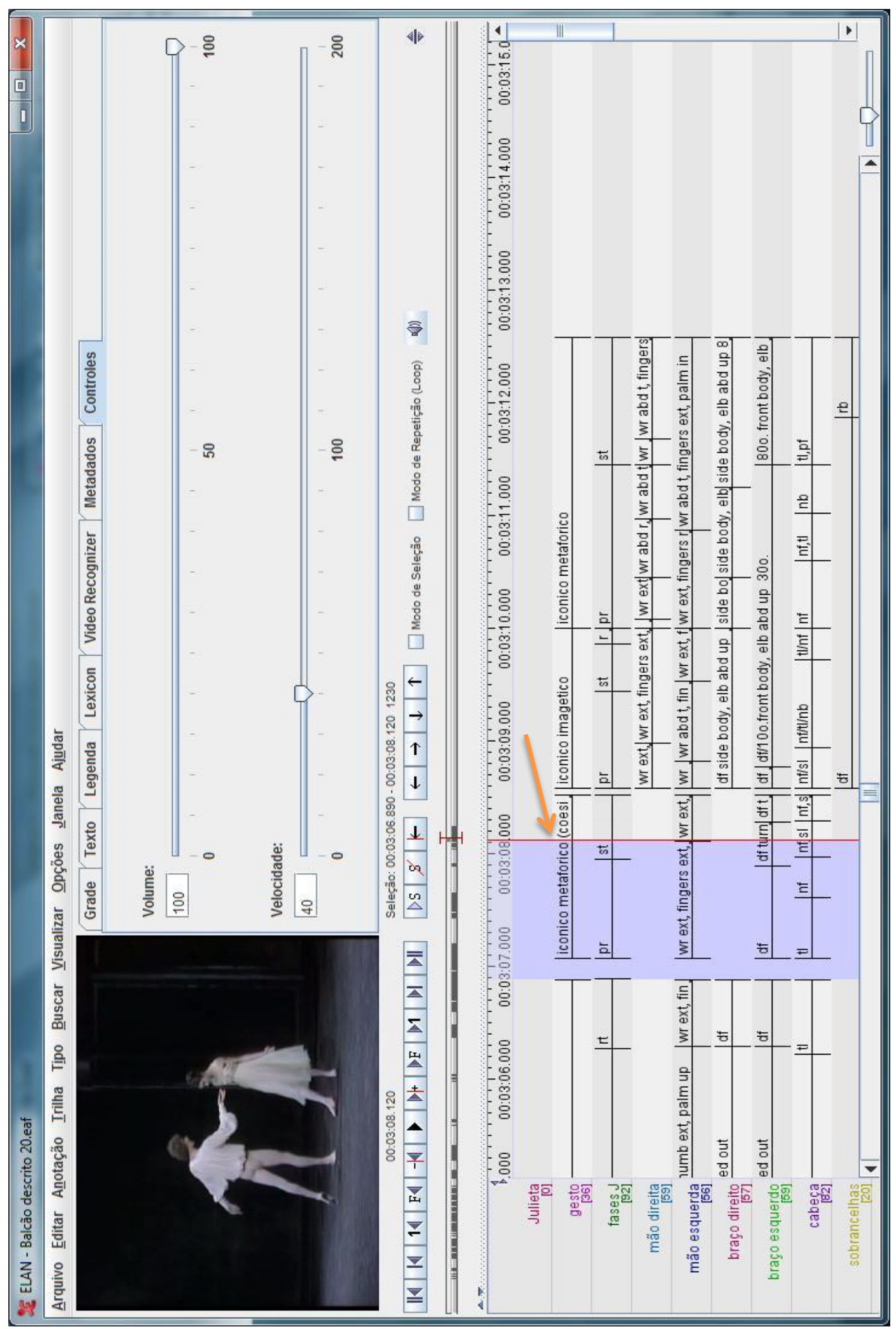

Figura 30. Janela do programa ELAN com transcrição para os dois bailarinos 
Assim como permite que várias trilhas sejam criadas de acordo com o detalhamento desejado, o software permite que o acesso seja feito a partir de cada uma das anotações. No caso abaixo, a janela do programa mostra a seleção a partir de uma trilha designada UI (que será apresentada na próxima seção), indicada pela seta laranja. Essa anotação pode compreender mais de uma anotação de gesto, como indicado pelas setas azuis.

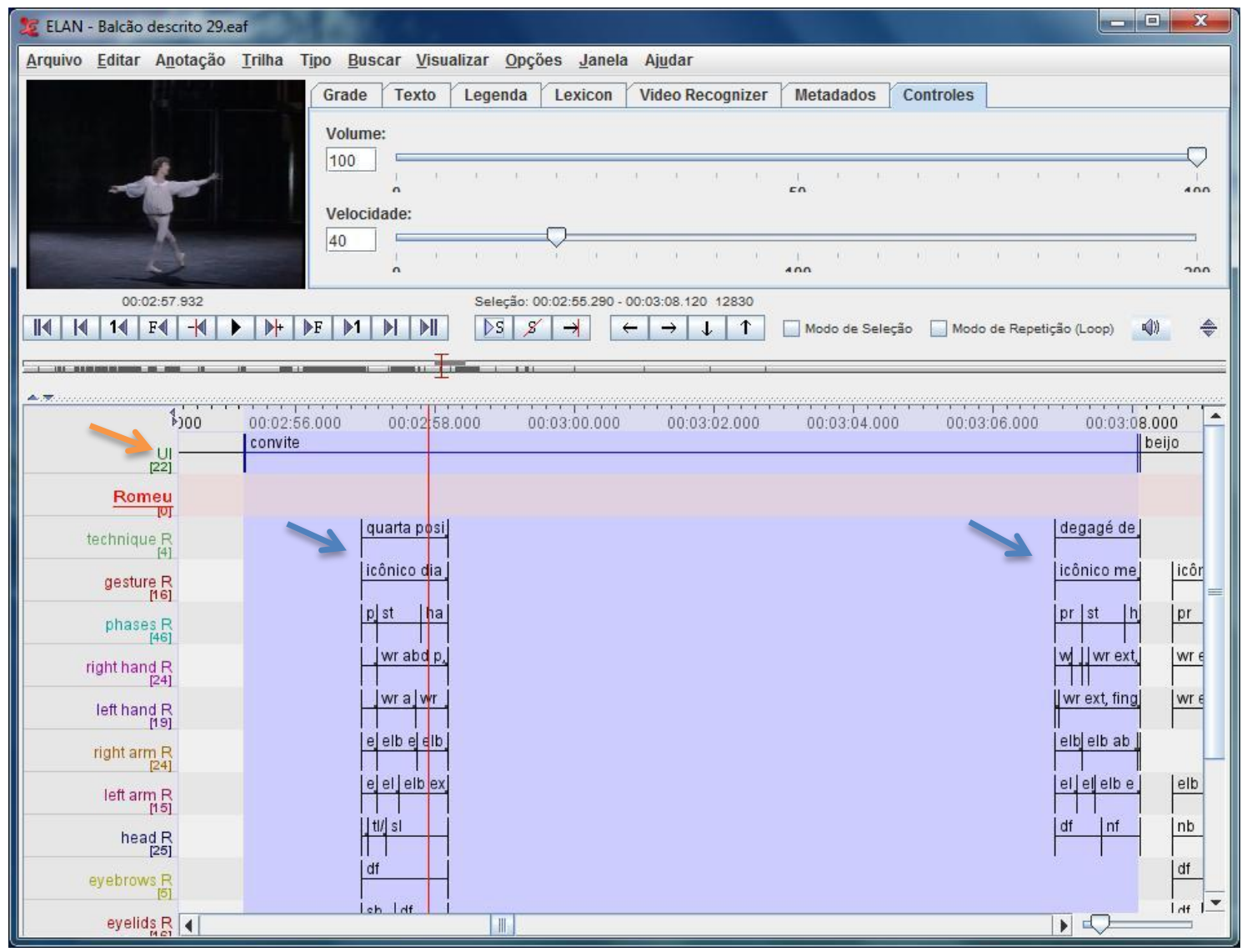

Figura 31. Janela do programa ELAN com trilha UI selecionada na transcrição do bailarino

Outro recurso proporcionado pelo software diz respeito ao ajuste no grau de aproximação, através do botão indicado. Como é possível observar na figura 32, as anotações podem ser reduzidas para uma visualização mais geral do conjunto de anotações. Com isso, as descrições ficam 'escondidas’ na visualização. 


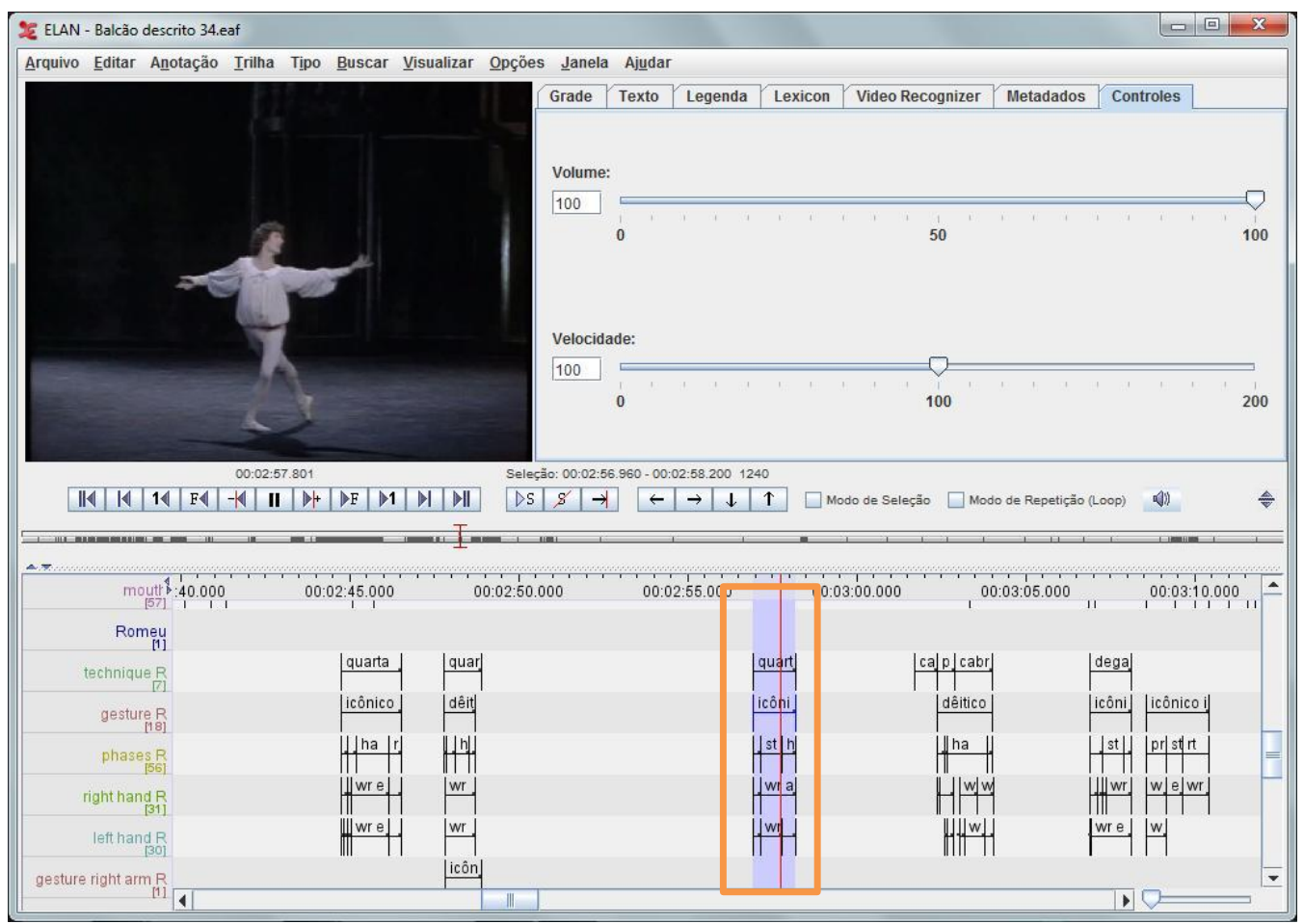

Figura 32. Janela do programa ELAN com a transcrição de gesto reduzida

Se o botão indicado pela seta laranja for acionado para a direita, é possível ter a visualização completa das anotações de um gesto, perdendo-se, no entanto, a visualização de outros gestos, como na tela da figura 33 .

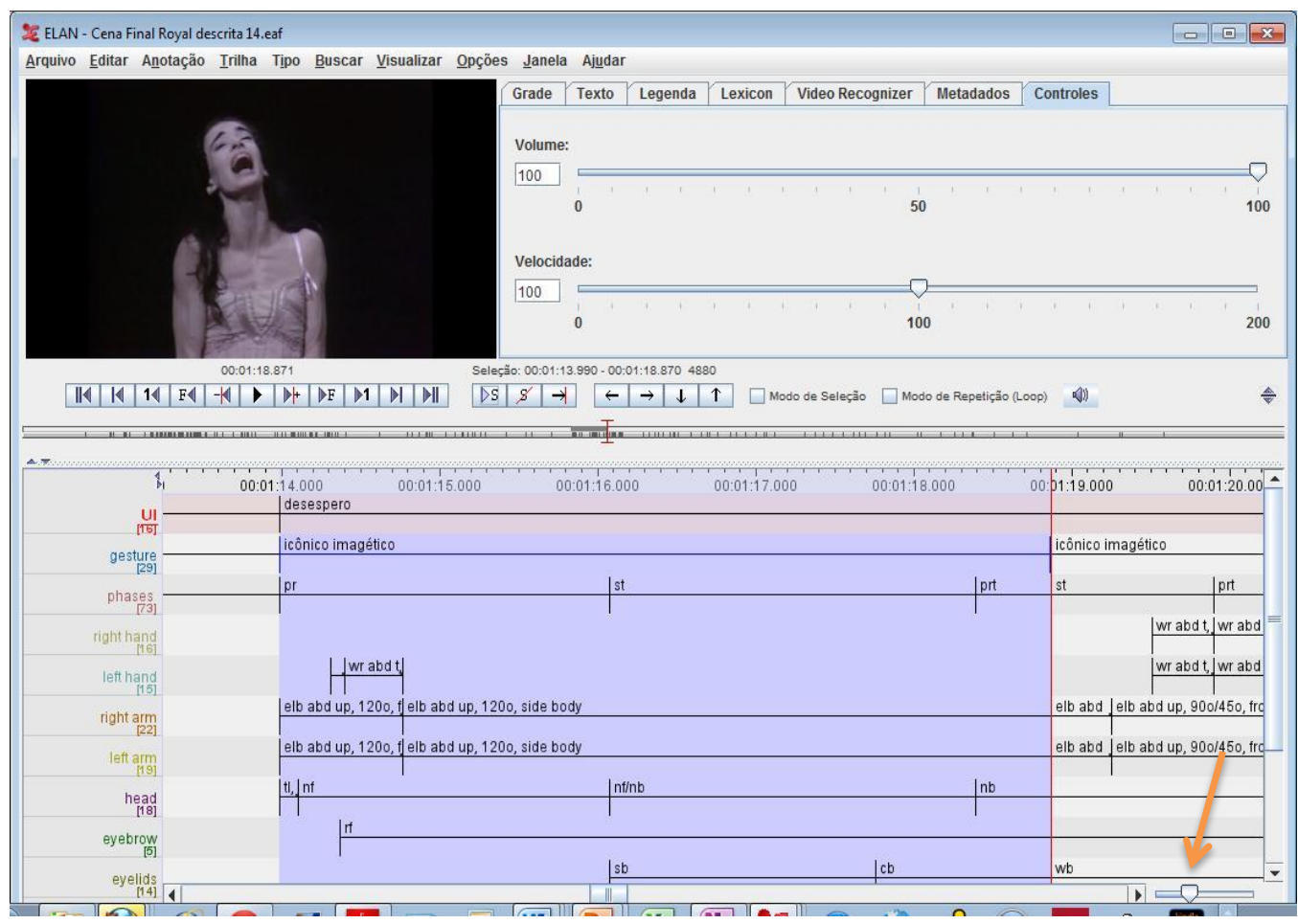

Figura 33. Janela do programa ELAN com a transcrição de gesto expandida 
É possível também visualizar na parte superior da tela, logo abaixo da janela de imagem na figura 34, o ponto no tempo do movimento e o intervalo de tempo utilizado para a execução do movimento. A referência de tempo pontual do movimento reproduzido no vídeo (e indicado pela barra vermelha) ocorre, no exemplo abaixo, a 02:57.932, e encontra-se apontado com a seta laranja. $\mathrm{O}$ intervalo de tempo do trecho selecionado (na área ressaltada em azul na imagem da tela) situa-se entre 02:55.290 e 03:08.120, e está apontado com a seta verde. Essas informações são necessárias para embasar a ocorrência de gestos coesivos, por exemplo, ou para observações do tempo utilizado para a realização do gesto, possibilitando estudos comparativos com gestos em línguas sinalizadas ou que acompanham a fala.

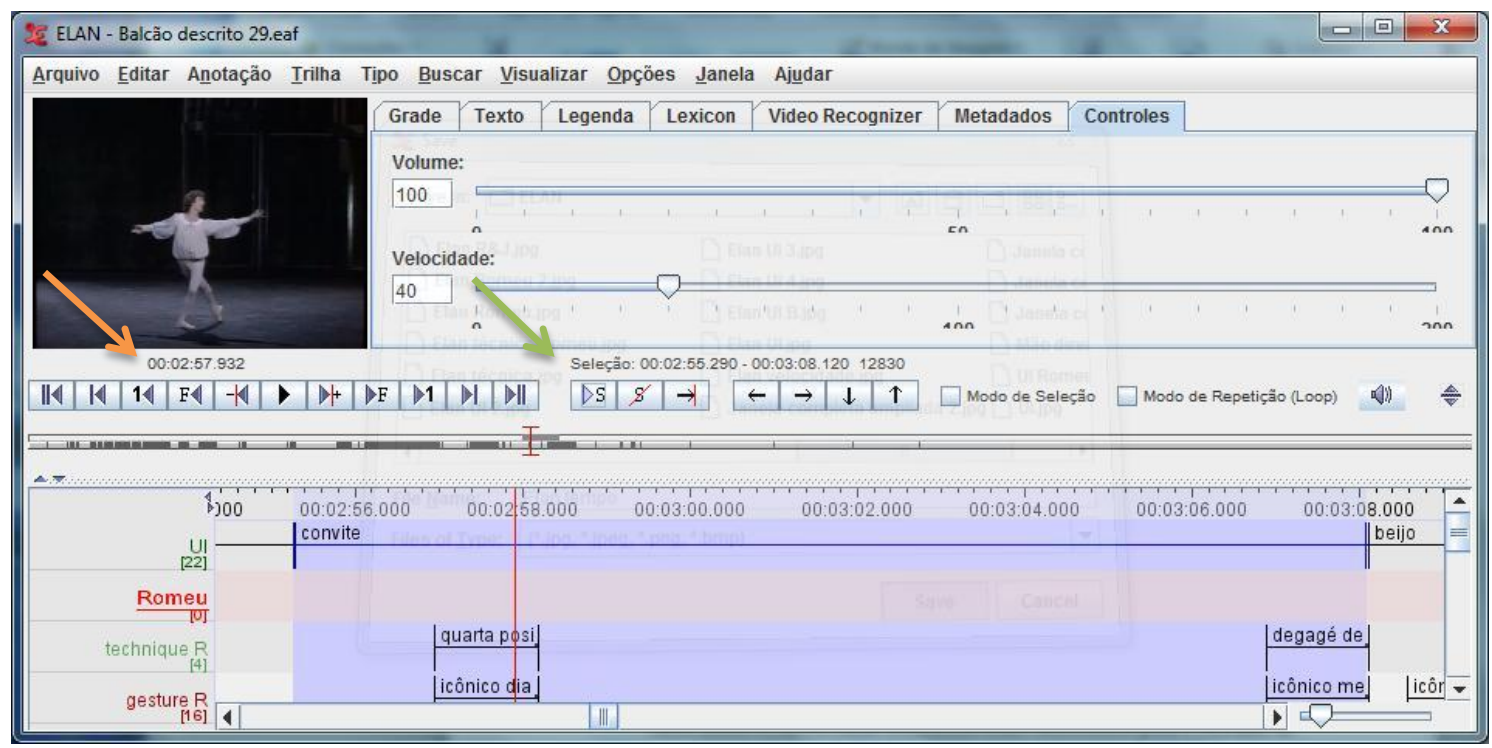

Figura 34. Janela do programa ELAN com indicação de referência de tempo pontual e sequencial

Além desses recursos, outra ferramenta importante para o trabalho de descrição é a possibilidade de alteração da velocidade do vídeo, para visualização do movimento em câmera lenta. $\mathrm{O}$ botão indicado pela seta laranja na figura 35 pode ser movido para a esquerda, para desacelerar o filme, ou para a direita, para acelerá-lo. Também há botões relativos à visualização quadro a quadro (setas azuis) ou a cada segundo (setas vermelhas). Esses recursos para visualizar a imagem são bastante úteis para anotar com precisão os movimentos envolvidos na realização de um gesto ou os pontos de transição entre dois movimentos, podendo ser usados tanto para recuar como para adiantar a imagem do movimento. 


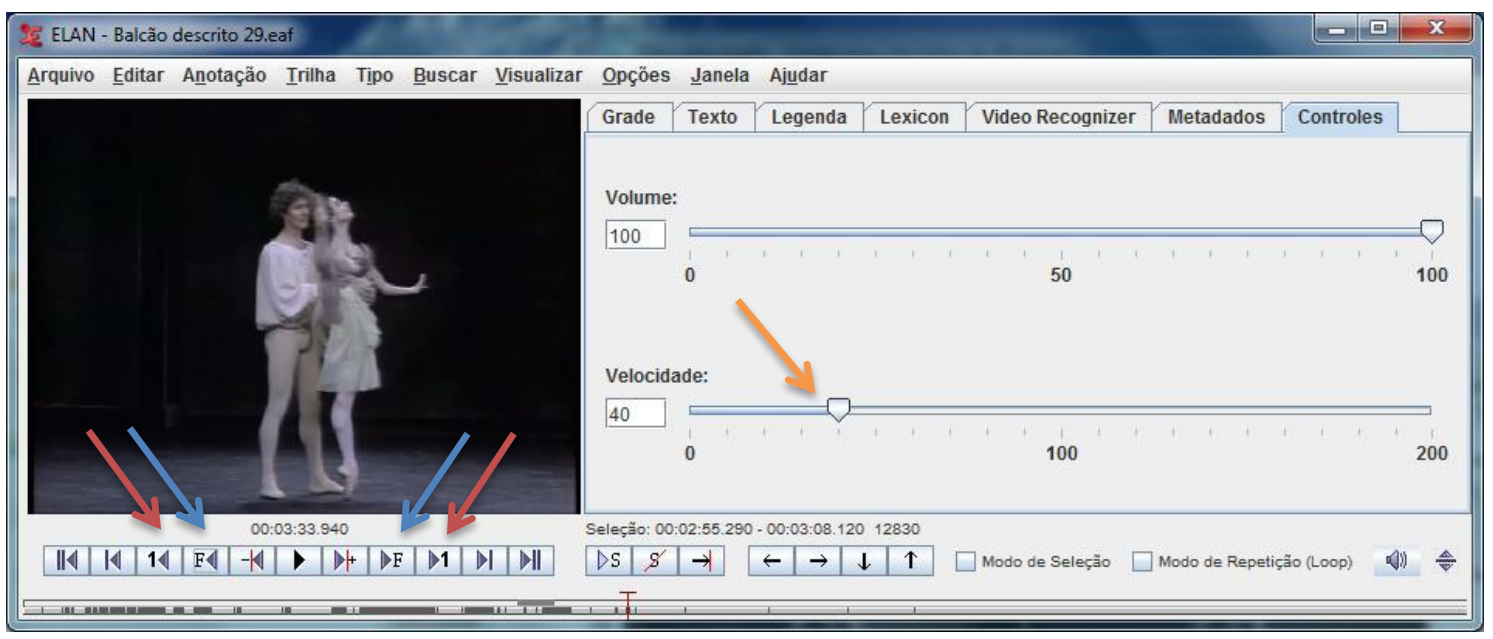

Figura 35. Janela do programa ELAN com indicação dos botões de velocidade do vídeo

Entre outros recursos, o programa permite restringir a visualização apenas do trecho selecionado, em modo pontual ou repetitivo, ou seja, o vídeo começa no início do trecho escolhido e para ao final da seleção. É possível, ainda, tocar a mídia de maneira contínua, do início ao fim da cena. Em ambos os casos, a pausa pode ser acionada a qualquer momento.

\subsubsection{Transcrição}

Pesquisadores da área de antropologia utilizam o sistema Labanotation para a descrição de danças. Esse sistema foi elaborado por Rudolf Laban em 1928, originalmente chamado de Kinetographie, e posteriormente desenvolvido, entre outros, por Ann Hutchinson Guest, nos Estados Unidos. O sistema abdica da língua escrita em favor de um desenho codificado, possibilitando a anotação de vários aspectos simultâneos da dança, como movimento dos membros, da cabeça, do tronco, das mãos, dos pés, velocidade, direção e fluência das sequências de movimento (Kaeppler 1972, Williams 1977, Hanna 1979, Farnell 1994). Para o presente trabalho, no entanto, esse sistema de notação apresentou as seguintes limitações: $i$ ) o sistema é bastante complexo, exigindo um treinamento especial e longo; e ii) se não houver proficiência na linguagem utilizada, seus resultados terão que ser traduzidos para uma linguagem convencional, tornando-se contrário ao objetivo principal da Labanotation, que é o de evitar as descrições de movimentos.

O sistema de notação chamado DanceWriting, desenvolvido por Valerie Sutton para o Balé Real Dinamarquês, em 1974 , tem as mesmas limitações, tanto no que se refere ao aprendizado do sistema quanto à sua viabilidade como instrumento de 
divulgação. Aliás, sua aprendizagem é dificultada por não haver centros autorizados a ensiná-la, como no caso da Labanotation, sendo o aprendizado realizado autonomamente, através de manuais. Poucos coreógrafos e companhias de dança optam por anotar as obras unicamente através de um ou outro sistema. De maneira geral, temse preferido o registro em filme para posterior remontagem ou o conjunto de registro escrito e visual. Do mesmo modo, poucos bailarinos são proficientes em sistemas de notação para que possam decodificá-los e remontar o trabalho sem a presença do próprio coreógrafo ou de um assistente por ele indicado.

Assim sendo, optei por utilizar o sistema proposto por McCleary, Viotti e Leite (2010) para línguas sinalizadas, já que os pesquisadores da área têm a mesma dificuldade com relação à descrição e análise do elemento gestual que acompanha a sinalização. Tanto quanto na dança, nos discursos sinalizados, uma única modalidade a visual-motora - é responsável por toda a expressão. Além disso, as transcrições trazem uma legibilidade maior do que aquela dos sistemas desenvolvidos para dança. Outro motivo para a preferência por esse sistema de transcrição é a possibilidade de diálogo com outras áreas que também contemplam o estudo do corpo como os estudos do gesto, os estudos sobre línguas sinalizadas e análise da conversa (Xavier 2006, Moreira 2007, Leite 2008, Bressem 2008, McCleary 2010, Pichler et al. 2010, McCleary, Viotti e Leite 2010, Hoetjes, Krahmer e Swerts 2012, McCleary e Viotti 2011, Bolgueroni 2013, Silva JP em preparação). Este trabalho configura uma fase exploratória na sistematização de uma transcrição apropriada para dança, através do programa ELAN.

McCleary, Viotti e Leite (2010) ressaltam a importância de um sistema de transcrição que inclui a escrita para possibilitar a divulgação do trabalho. Esse trabalho de transcrição exige uma observação minuciosa por parte do pesquisador. Apesar disso, a anotação dos dados não deve sobrecarregar a transcrição com informações que não sejam relevantes para a análise linguística, ao menos em um primeiro momento. Citando DuBois et al. (1990), eles esclarecem que o trabalho de transcrição, ainda que tente ser o mais objetivo possível, está sujeito à interpretação do pesquisador. Assim, é importante buscar não categorizar os dados durante a transcrição, tentando manter a distinção entre o que é o dado propriamente e o que pode ser uma interpretação do dado. A ideia é primeiramente descrever, para depois interpretar, buscando evitar que os dados fiquem enviesados por interpretações prematuras. McCleary, Viotti e Leite 
ressaltam, ainda, a importância de o responsável pela transcrição (e/ou seus informantes) ser proficiente na língua a ser transcrita.

Algumas adaptações foram necessárias para a adequação do método utilizado para transcrição da língua de sinais brasileira à transcrição de dança. Entre elas estão, por exemplo, a supressão da trilha que registra imagens bucais ${ }^{45}$, constante em McCleary, Viotti e Leite (2010), mas que não possui aplicação para dança, e a inclusão de uma trilha específica para braço direito e braço esquerdo, dada sua integração na composição do significado gestual como já apontado anteriormente ${ }^{46}$. A trilha referente a gestos bucais - que são sinais não manuais das línguas sinalizadas produzidos com a parte inferior da face - foi nomeada simplesmente boca. Foram feitas algumas adaptações ao vocabulário utilizado para a transcrição desses sinais não manuais das línguas de sinais. Incorporei à transcrição das trilhas de mãos, com relação à configuração de dedos e de punho, algumas das propostas apresentadas por Johnson e Liddell (2011). Utilizei, ainda, parte da configuração de punho para a descrição da configuração de cotovelos.

Para a anotação das configurações, utilizei o vocabulário controlado proposto por McCleary, Viotti e Leite (2010). O vocabulário controlado é o conjunto de nomenclaturas para todas as possibilidades de configuração dos diversos articuladores. Com base nessa nomenclatura, estabeleci os termos para as trilhas inseridas ou modificadas para a transcrição das narrativas dançadas. Esse vocabulário usa siglas baseadas em posições ou movimentos descritos em língua inglesa. Por exemplo, na trilha relativa à postura dos ombros, há as siglas $d f$, para posição neutra dos ombros, que utiliza as duas primeiras consoantes do vocábulo default em inglês para formar a sigla;

\footnotetext{
${ }^{45}$ Imagens bucais são configurações da boca que se relacionam com a língua oral falada no local em que a comunidade surda se insere.

${ }^{46}$ McCleary, Viotti e Leite (2010) propõem as seguintes trilhas para a transcrição da língua de sinais brasileira (LIBRAS): IU Translation (Unidades Entoacionais), MS-Gloss-BP (glosa de sinais manuais em português), MS-Gloss-E (glosa de sinais manuais em inglês), NMS-Gloss-BP (glosa de sinais nãomanuais em português), NMS-Gloss-E (glosa de sinais não-manuais e inglês),SMS-Gloss-BP (glosa de sinais manuais realizados simultaneamente a outros sinais),Eyebrow (configurações de sobrancelhas), Eyegaze (configurações e movimentos de olhar), Hands (qual mão realiza o sinal), Location (localização da mão no espaço de sinalização), Repetition (registro do número de repetições constitutivas do sinal), Dictionary (número da página da entrada em Capovilla e Raphael), Comments (comentários sobre a transcrição), Head (configurações e movimentos de cabeça), Eyelids (configurações e movimentos de pálpebras), Body (configurações e movimentos de tronco), Shoulders (configurações e movimentos de ombros), Mouth Pictures (registro de visemas), Mouth Gestures (gestos bucais sem relação com o português), G-phases (fases do gesto).
} 
$u l$, utilizada para indicar a elevação do ombro esquerdo, vem das consoantes inicias da expressão up left, do inglês; $u b$, utilizada para descrever a elevação de ambos os ombros, que vem da expressão up both, entre outras. Assim, quando inclui siglas nessa trilha, busquei manter a mesma proposta de simplificação da padronização de dados através das siglas $b l$, para indicar o movimento do ombro esquerdo para trás, criada a partir de back left; br, para descrever o movimento do ombro direito para trás, criada a partir de back right; e $b b$, para indicar o movimento de ambos os ombros para trás, a partir da expressão both back.

A primeira divisão do material foi feita em unidades ideacionais, que são a expressão de um conjunto coeso de informação correspondente a um foco de consciência (Chafe 1980a, p. 40) e limitado pela nossa capacidade de processamento ${ }^{47}$. Dividi, então, as cenas em frases coreográficas ligadas a uma mesma ideia, tratando-as como unidades ideacionais (UI). Assim, a primeira trilha da transcrição apresenta a divisão em UIs. A seguir, partindo da proposta de McCleary, Viotti e Leite (2010), apresento as trilhas utilizadas:

\section{i) UI}

As unidades ideacionais são identificadas pela ideia central expressa na sequência de frases coreográficas. No exemplo abaixo, retirado da cena final na versão inglesa, o ponto em que se encontra a imagem do vídeo (indicado pela barra vermelha) está na UI 'percepção da morte de Romeu'. Essa unidade encontra-se precedida pela UI 'encontro do corpo de Romeu' e seguida pela UI 'tristeza profunda'. A sequência de unidades ideacionais tem início com o despertar de Julieta e termina com sua morte, ao final da cena.

47 Em língua oral, essas unidades foram posteriormente chamadas por Chafe (1994) unidades entoacionais, ou seja, representam focos de consciência que, quando associados à linguagem, traduzemse em unidades que exibem um certo padrão entoacional e sintático. Em discurso oral, a caracterização de uma unidade faz-se pela identificação de uma ou todas as seguintes características: mudanças na frequência fundamental (percebida como altura), mudanças na duração (percebida como alongamento ou encurtamento de sílabas ou palavras), mudanças na intensidade (percebida como volume), alternância de vocalização e silêncio (percebida como pausa), mudanças na qualidade vocal, e algumas vezes, mudanças de turno. Em dança ainda não é possível determinar aspectos do contorno entoacional, por isso preferi o termo mais antigo proposto por Chafe (1980) - unidades ideacionais. 


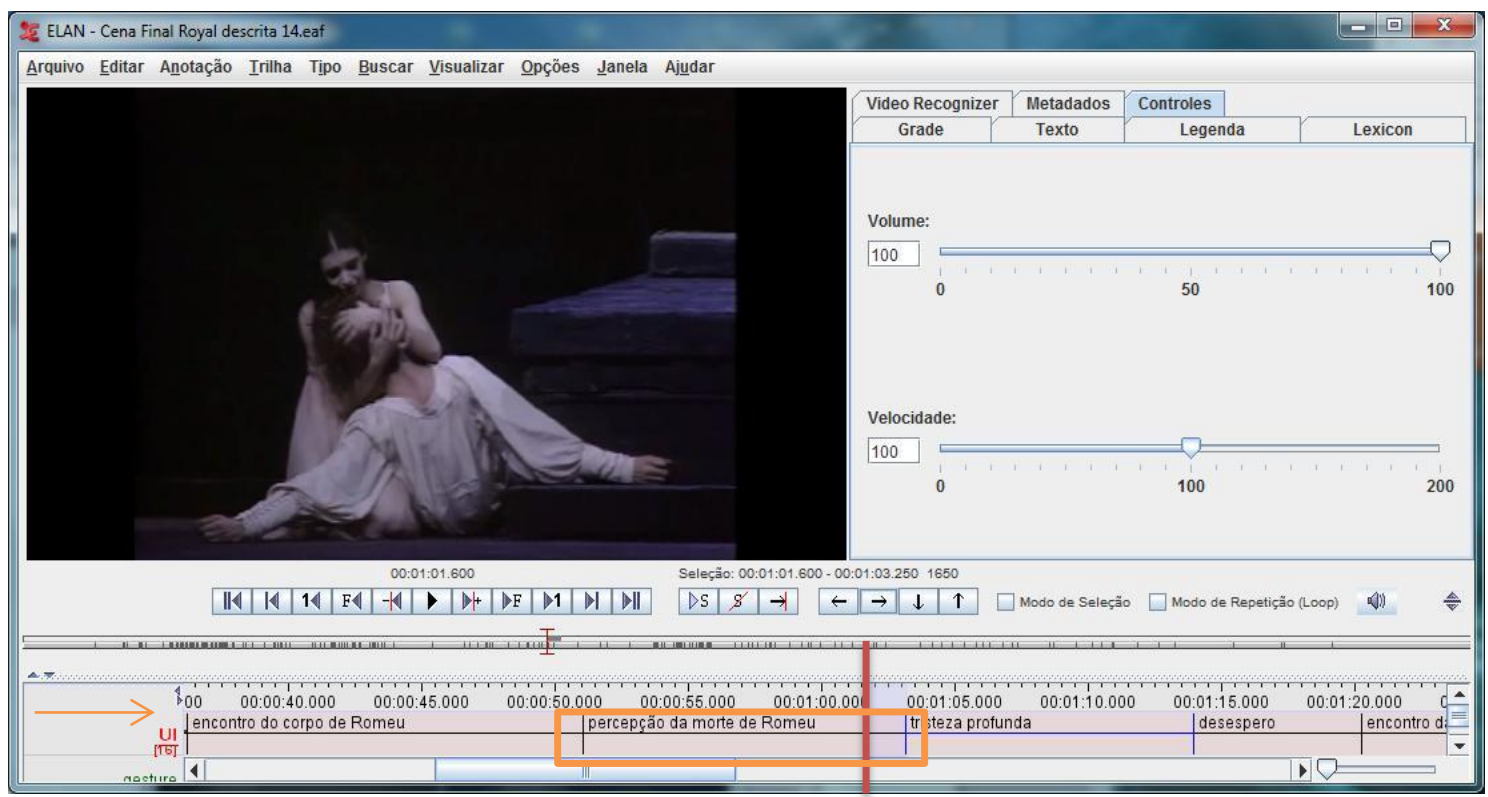

Figura 36. Exemplo de trilha UI (unidade ideacional), retirado da cena final da versão inglesa

\section{ii) Gesto}

A classificação foi feita a partir da proposta apresentada na tabela 2 da seção 1.2.2 (gestos dêiticos, icônicos imagéticos, icônicos diagramáticos, icônicos metafóricos, coesivos e batidas). No exemplo abaixo, a seleção recai sobre um gesto realizado com os braços, mãos e cabeça por Julieta e classificado como icônico metafórico, que se encontra entre um gesto dêitico e um gesto icônico imagético. $\mathrm{O}$ ponto na transcrição correspondente ao momento da imagem do vídeo está marcado pela barra vermelha. 


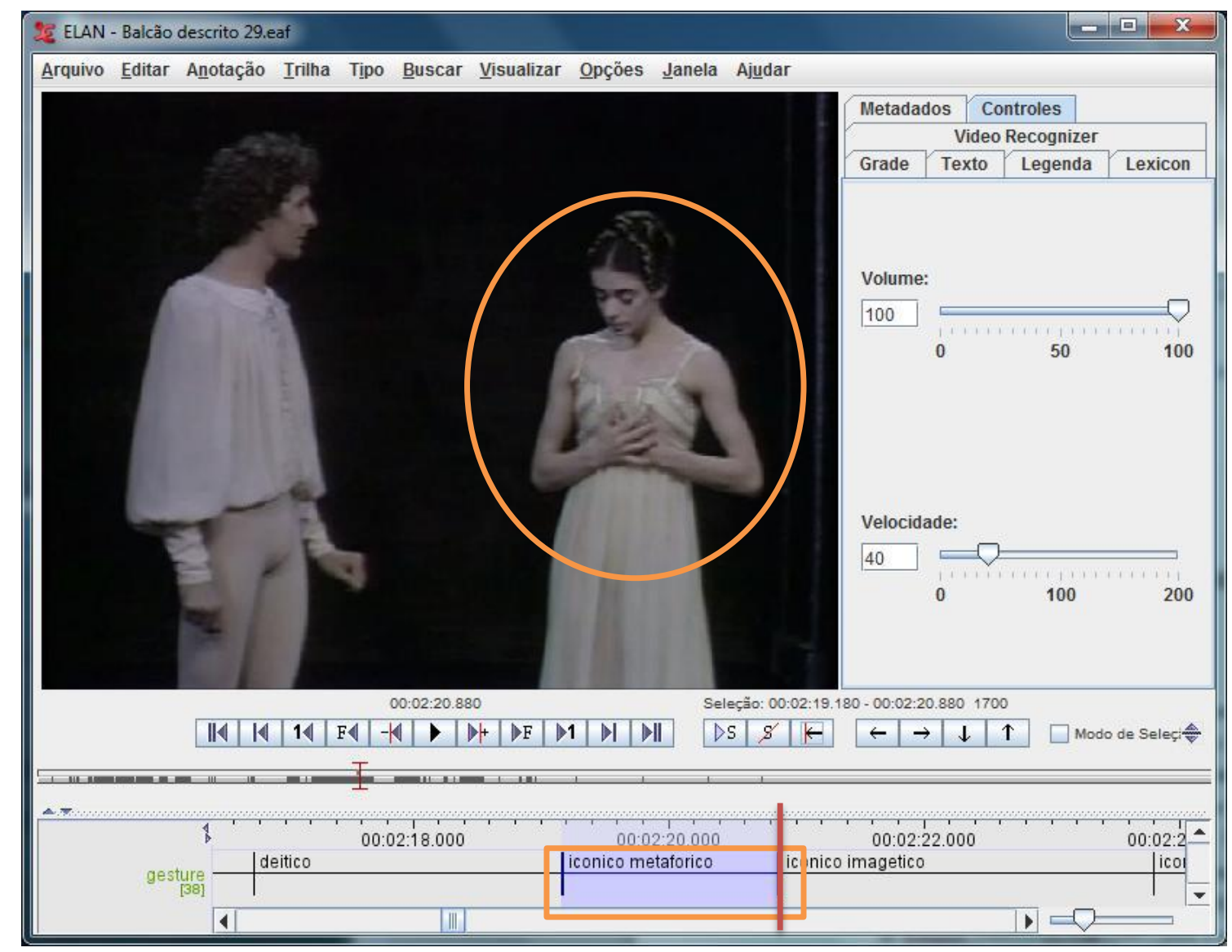

Figura 37. Exemplo da trilha Gesto, retirado da cena do balcão na versão inglesa

\section{iii) Fases do gesto}

Os gestos podem ser segmentados temporalmente em fases distintas: (i) a preparação, anterior à fala, no caso de gestos coverbais; (ii) o golpe do gesto ("stroke phase"), coincidente com a proeminência fonológica, semântica ou pragmática da frase; e (iii) a retração, que não está necessariamente atrelada à construção de significação. Há, ainda, a pausa no desenvolvimento do gesto, usada para sincronizar o golpe do gesto com o ponto adequado do discurso. Kita et al. (1998), desenvolvendo as propostas iniciais de Kendon (1980) e McNeill (1992) para a segmentação temporal dos gestos, organiza os movimentos, e introduz novos elementos à cadeia frasal dos gestos da seguinte forma: preparação, (suspensão expressiva), (suspensão pré-golpe), golpe, (suspensão pós-golpe) e retração. Os termos entre parênteses correspondem ao conceito de pausa de McNeill, e suas posições são determinadas pela fase expressiva, podendo ou não ocorrer no gesto. Uma curva completa, incluindo, basicamente, preparação, golpe e retração, é chamada frase gestual. Há, no entanto, outras configurações de frase, que podem incluir ou não as pausas e outras fases do gesto. Para Kita et al. 1998, apenas a fase expressiva (ou golpe) é obrigatória para a configuração de uma frase gestual. 
Esse, no entanto, ainda é um ponto aberto a discussões. Uma ou mais frases gestuais compõem a unidade gestual, que se caracteriza por iniciar-se e terminar em posição de repouso $^{48}$. No exemplo abaixo, a seleção mostra um gesto da bailarina que apresenta três fases: preparação, golpe e suspensão pós-golpe. O momento retratado, indicado pela barra vermelha, situa-se na fase suspensão pós-golpe.

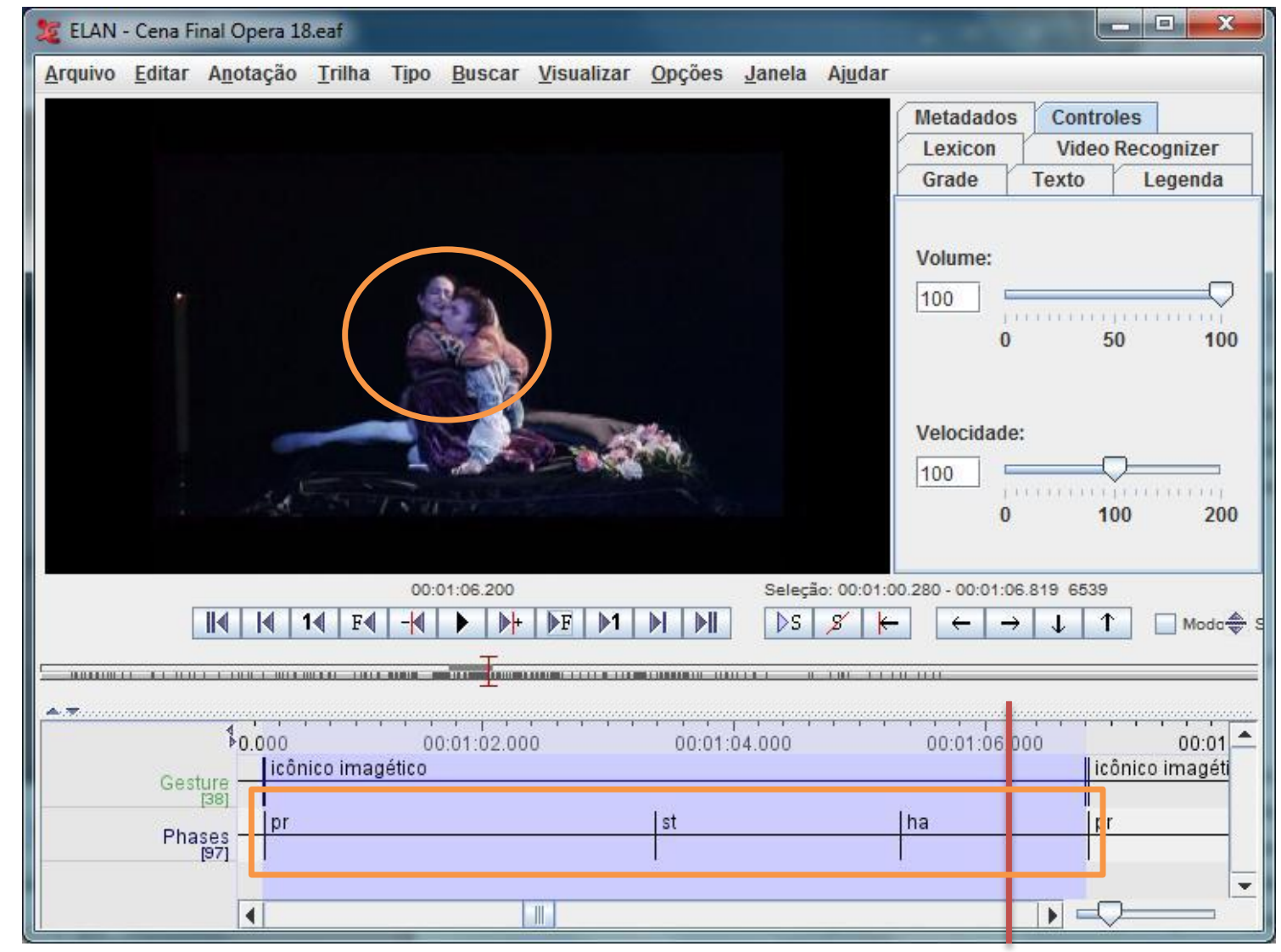

Figura 38. Exemplo das trilhas Gesto e Fases do gesto, referentes à bailarina, retirado da cena final na versão francesa

\section{iv) Mão direita}

A descrição da configuração manual inclui a posição da palma da mão, do punho e dos $\operatorname{dedos}^{49}$. Na figura abaixo, a seleção mostra o ponto limítrofe entre duas

\footnotetext{
${ }^{48} \mathrm{Na}$ nomenclatura utilizada, o vocabulário controlado de McCleary, Viotti e Leite (2010), a sigla $\mathrm{pr}$ refere-se à fase de preparação; st corresponde ao golpe; $h b$ significa suspensão antes do golpe; $h a$ referese à suspensão depois do golpe; prt indica retração parcial e $r t$ é usado para a retração.

${ }^{49}$ Para a transcrição das mãos, houve adaptação do vocabulário controlado, a partir de Johnson e Liddell (2011). As siglas utilizadas são: $i$ ) $w r$ para o punho, podendo ser ext (estendido), abd $t$ (flexionado em direção ao dorso da mão) ou abd p (flexionado em direção à palma da mão); ii) fingers para os dedos da mão, podendo ser relax (relaxados), ext (estendidos) ou abd (flexionados) - quando necessário, os dedos são indicados pelos seus nomes em inglês thumb, index, middle, ring e little (correspondendo a polegar, indicador, médio, anular e mínimo)-; iii) palm para palma da mão, podendo ser up (para cima), down
} 
configurações de mão. Na primeira seção, o punho está flexionado em direção à palma da mão, com os dedos flexionados e a palma virada para dentro. Na seção seguinte, o punho mantém-se flexionado em direção à palma da mão, os dedos relaxam e a palma da mão continua virada para dentro, em relação ao corpo da bailarina. $\mathrm{O}$ ponto da imagem encontra-se assinalado pela barra vermelha.

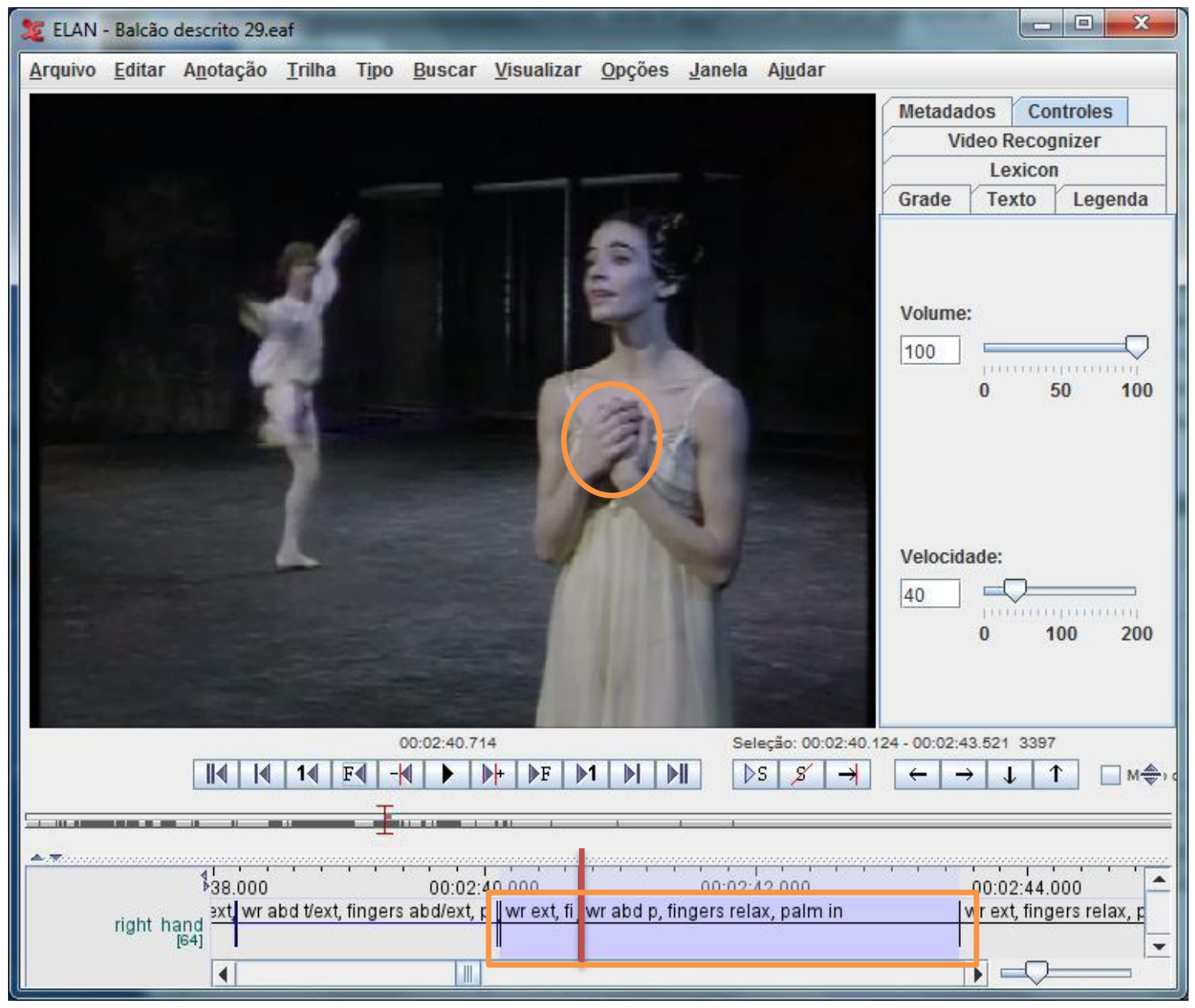

Figura 39. Exemplo da trilha mão direita, retirado da cena do balcão da versão inglesa

\section{v) Mão esquerda}

Como mencionado em relação à trilha mão direita, a descrição de configuração manual inclui a posição da palma da mão, do punho e dos dedos. $\mathrm{O}$ trecho selecionado mostra a seguinte configuração da mão esquerda do bailarino: punho flexionado em direção à palma da mão, dedos relaxados e palma da mão virada para dentro, em relação ao corpo da bailarina. O momento que aparece no vídeo está indicado na transcrição pela barra vermelha.

(para baixo), in (para dentro, em relação ao corpo do bailarino) ou out (para fora, em relação ao corpo do bailarino). 


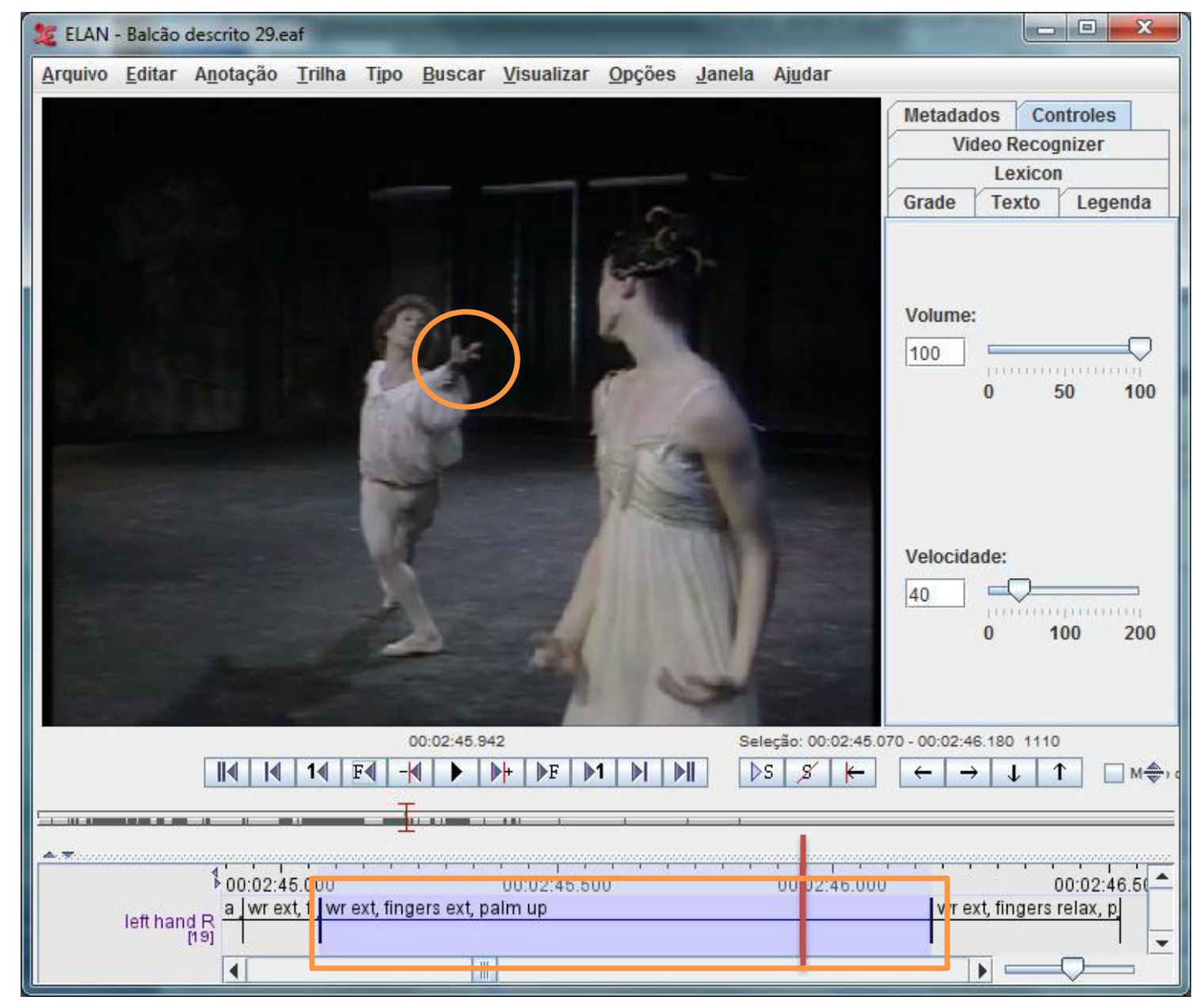

Figura 40. Exemplo da trilha mão esquerda, retirado da cena do balcão da versão inglesa

\section{vi) Braço direito}

Essa trilha descreve o movimento e posicionamento do braço direito ${ }^{50}$. No exemplo da figura 41, o trecho selecionado apresenta o braço direito flexionado para dentro, em relação ao corpo da bailarina, formando um ângulo entre o braço e o antebraço que vai dos cento e dez aos noventa graus, utilizando o espaço à frente do corpo. O momento do vídeo correspondente ao ponto na transcrição está indicado pela barra vermelha.

${ }^{50}$ No caso da descrição de braços, o vocabulário controlado criado por mim é composto pelas seguintes siglas: i) elb para cotovelo, podendo ser relax (relaxado), ext (estendido), abd in (antebraço flexionado para dentro em relação ao corpo do bailarino), abd out (antebraço flexionado para fora com o braço posicionado na lateral do corpo), abd up (antebraço flexionado de baixo para cima) ou abd down (antebraço flexionado de cima para baixo); ii) gradação da relação antebraço/cotovelo, por exemplo, $90^{\circ}$ (formando um ângulo de noventa graus); e iii) side body/ side head (posição do braço na lateral do corpo ou na lateral da cabeça do bailarino), front body (posição do braço na frente do corpo do bailarino) ou back body (posição do braço atrás do corpo do bailarino). 


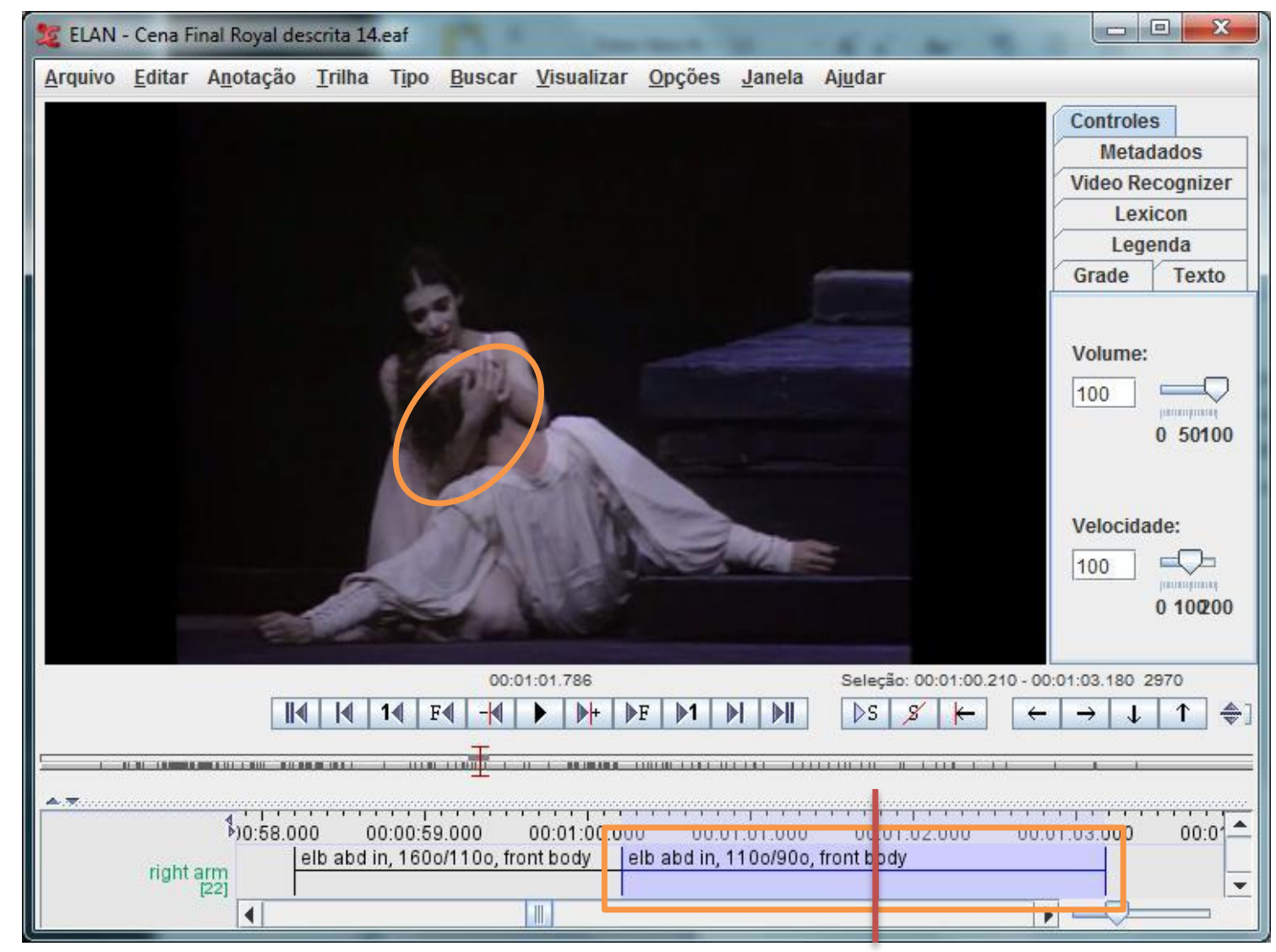

Figura 41. Exemplo da trilha braço direito, retirado da cena final da versão inglesa

\section{vii) Braço esquerdo}

Nessa trilha é feita a descrição de movimento e posicionamento do braço esquerdo. No exemplo abaixo, o braço esquerdo da bailarina tem o cotovelo flexionado para dentro, em relação ao corpo, formando um ângulo entre o braço e o antebraço que vai de cento e dez a oitenta graus, na frente do corpo. O ponto na transcrição que corresponde à imagem do vídeo está indicado pela barra vermelha. 


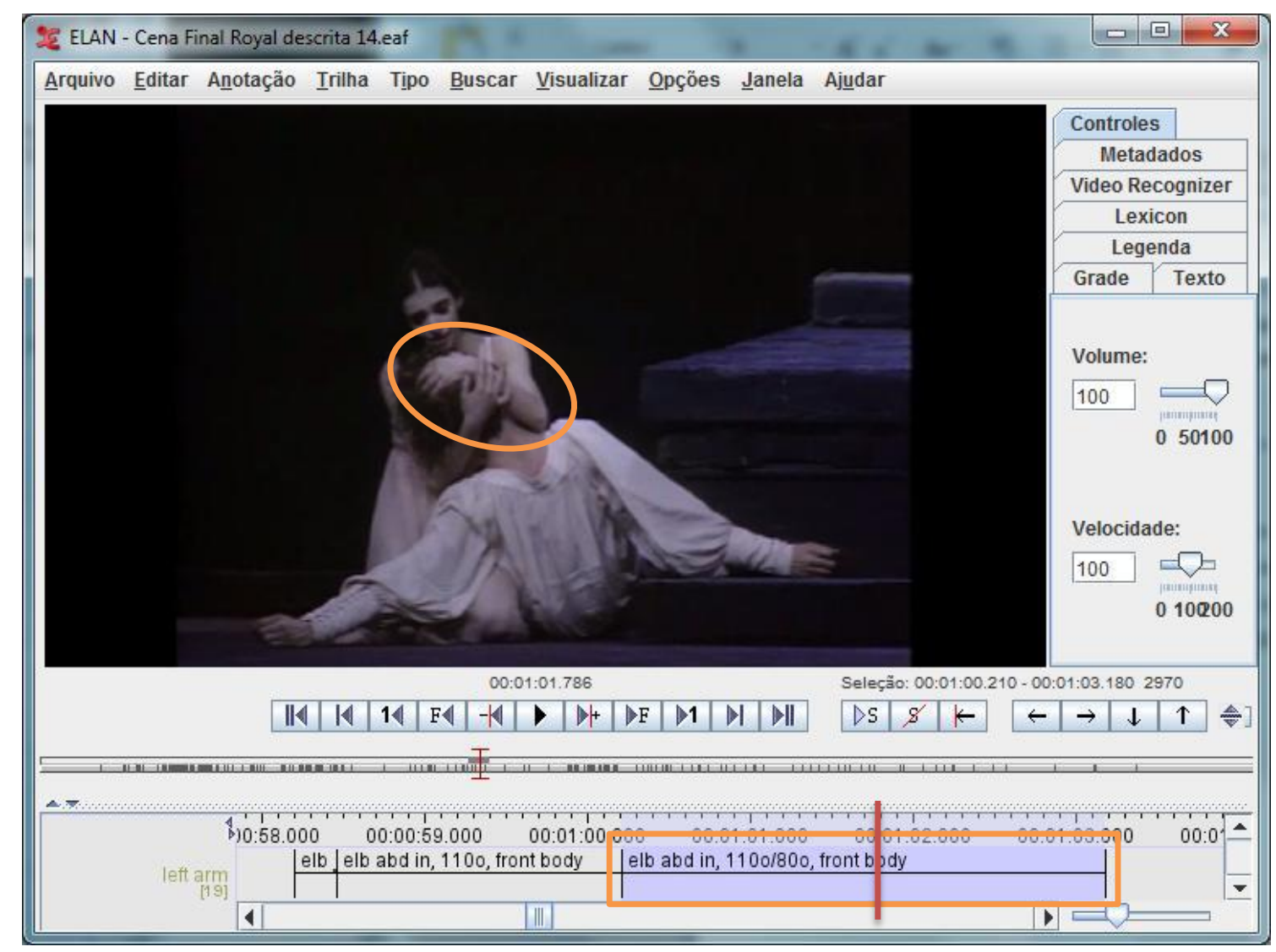

Figura 42. Exemplo da trilha braço esquerdo, retirado da cena final da versão inglesa

viii) Ombros

Essa trilha descreve movimento e posição dos ombros durante o gesto ${ }^{51}$. Na figura abaixo, o trecho selecionado descreve a posição dos dois ombros, que estão deslocados para trás. O movimento completo dos ombros incluirá as descrições precedentes. O ponto na transcrição correspondente à imagem do vídeo está assinalado com a barra vermelha.

${ }^{51}$ A descrição do movimento ou posição dos ombros é selecionada a partir das seguintes possibilidades, dentro do vocabulário controlado apresentado em McCleary,Viotti e Leite (2010): $i$ ) $d f$ (posição neutra); ii) $u l$ (ombro esquerdo levantado); iii) ur (ombro direito levantado); $i v) ~ u b$ (ambos os ombros levantados); v) $h l$ (ombro esquerdo deslocado para frente); vi) $h r$ (ombro direito deslocado para frente); vii) $h b$ (ambos os ombros deslocados para frente); viii) $s l$ (ombro esquerdo se move para cima e para baixo repetidas vezes); $i x$ ) $s r$ (ombro direito se move para cima e para baixo repetidas vezes); $x$ ) $s b$ (ambos os ombros se movem para cima e para baixo repetidas vezes); $x i) b l$ (ombro esquerdo deslocado para trás); $x i i$ ) $b r$ (ombro direito deslocado para trás); e xiii) $b b$ (ambos os ombros deslocados para trás). Os itens $x i$, xii e xiii foram introduzidos por mim ao vocabulário, devido a necessidades específicas com relação a movimentos realizados em dança. 


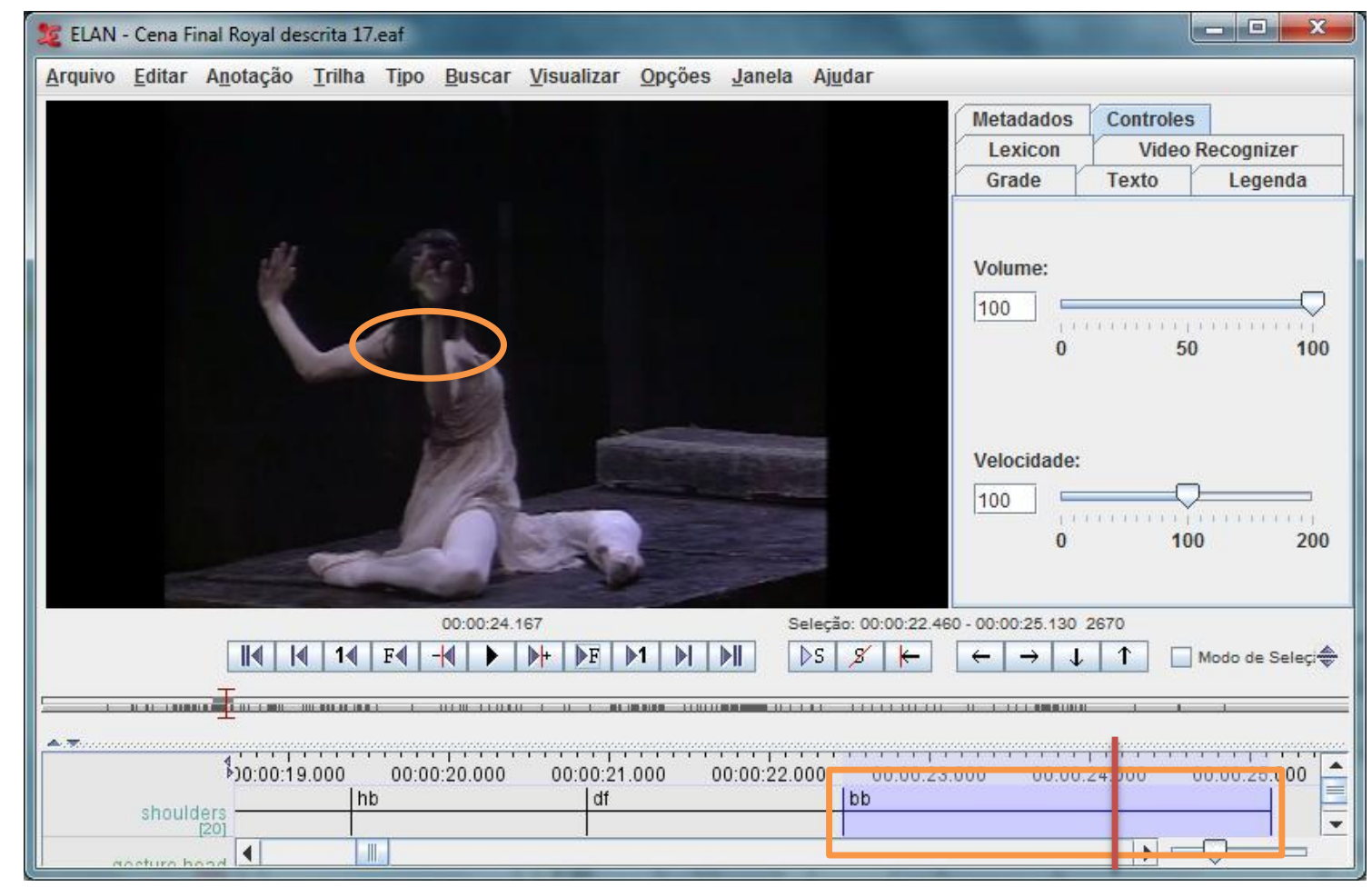

Figura 43. Exemplo da trilha ombros, retirado da cena final na versão inglesa

\section{ix) Torso}

A descrição de movimento e posicionamento do corpo é feita nessa trilha ${ }^{52}$. A relação entre as cinturas escapular (dos ombros) e pélvica (do quadril) não está diretamente descrita na transcrição. Na figura 44, a bailarina realiza um movimento que começa com o torso virado para a direita, passa pela posição neutra e depois se inclina para frente. Esse movimento completo encontra-se compreendido entre as fases de preparação e golpe do gesto dêitico sendo realizado. O momento do vídeo encontra-se indicado pela barra vermelha na transcrição.

52 O torso foi descrito a partir do seguinte vocabulário controlado, apresentado por McCleary, Viotti e Leite (2010): i) $d f$ (posição neutra); ii) $r$ (torso virado para a esquerda); iii) $r r$ (torso virado para a direita); $i v) t l$ (torso inclinado para a esquerda); $v$ ) $t r$ (torso inclinado para a direita); $v i$ ) $t f$ (torso inclinado para frente); vii) tb (torso inclinado para trás); viii) si (suspiro, inspira e expira profundamente); $i x$ ) he (peito estufado); $x$ ) st (costas retas); e $x i$ ) rd (costas curvadas). 


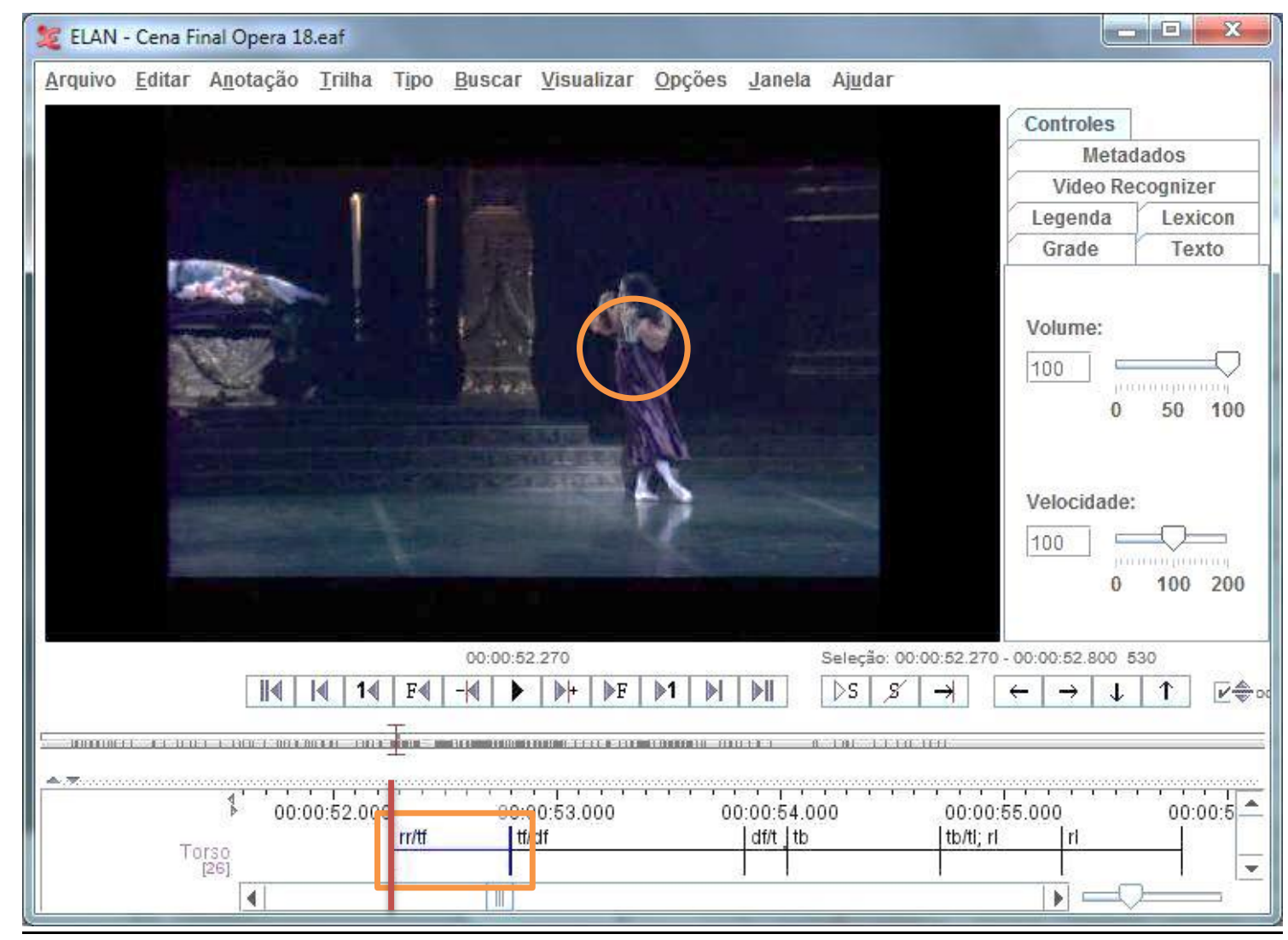

Figura 44. Exemplo da trilha torso, retirado da transcrição da cena final na versão francesa

x) Cabeça

Nessa trilha anota-se a descrição de movimento e de posicionamento da cabeça $^{53}$. No exemplo abaixo, a bailarina realiza um movimento com a cabeça virada para a direita, na fase preparatória do gesto dêitico. Na sequência, o movimento de cabeça acompanha o olhar. A barra vermelha na transcrição indica o momento inicial que pode ser visto na imagem de vídeo.

${ }^{53}$ A descrição da postura e do movimento de cabeça foi feita a partir do seguinte vocabulário apresentado em McCleary, Viotti e Leite (2010): i) $d f$ (posição neutra); ii) no (aceno de cabeça repetido); iii) sh (movimento de 'não'); iv) $s r$ (virar para a direita); $v$ ) $s l$ (virar para a esquerda); vi) tr (inclinada para a direita); vii) $t l$ (inclinada para a esquerda); viii) $n f$ (inclinada para frente); ix) $n b$ (inclinada para trás); $x$ ) $p f$ (deslocada para frente); e xi) li (movimento de cabeça associado à direção do olhar). 


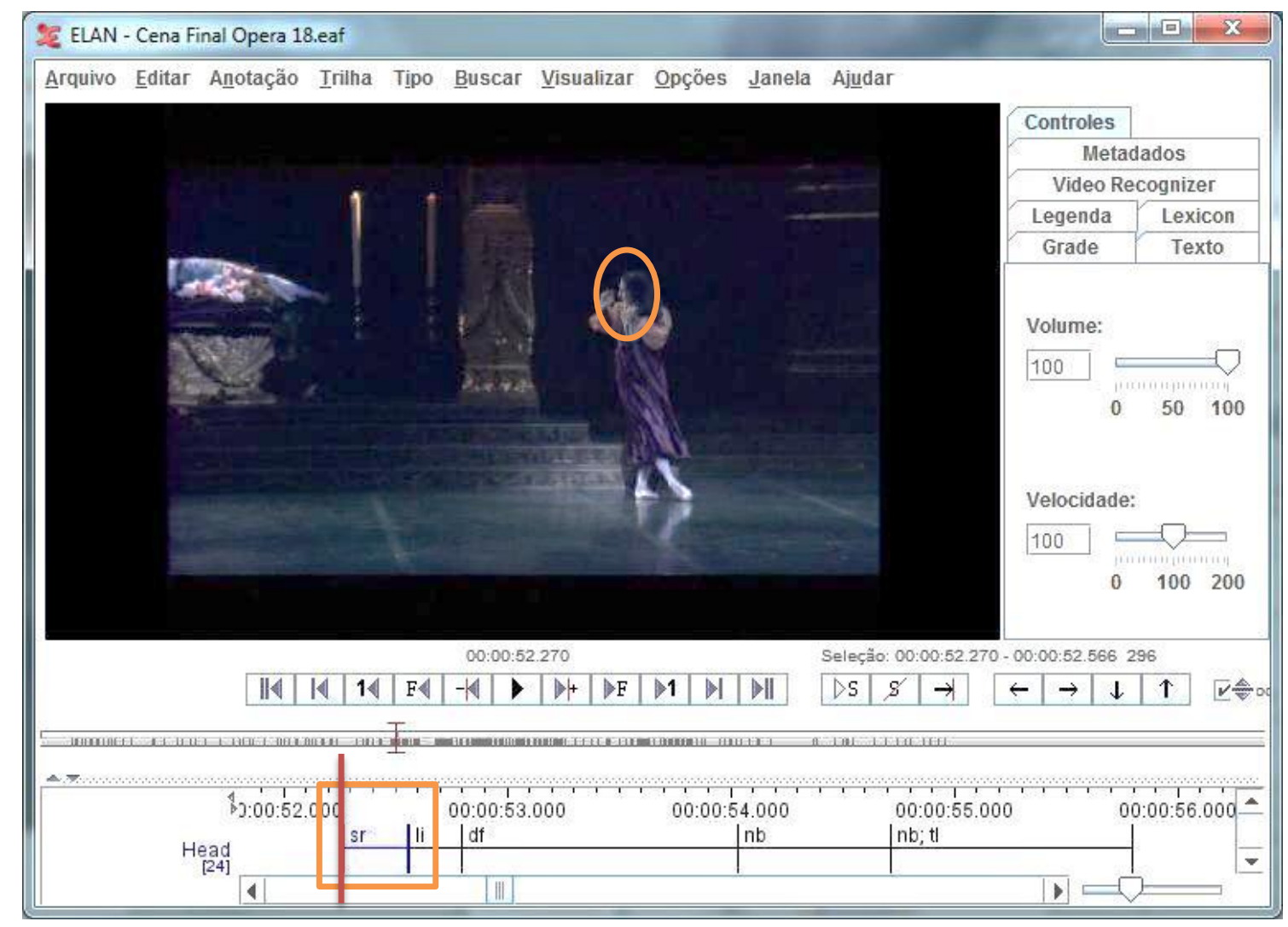

Figura 45. Exemplo da trilha cabeça, retirado da transcrição da cena final na versão francesa

\section{xi) Sobrancelhas}

Essa trilha é usada para descrever a configuração das sobrancelhas ${ }^{54}$. Na figura 46 vemos a bailarina levantando as extremidades internas das sobrancelhas e franzindo a testa. Essa configuração, produzida na fase de preparação do gesto, será mantida no golpe e na retração parcial do gesto icônico imagético que a bailarina produz na imagem do vídeo. Na verdade, ela ainda será mantida no gesto icônico imagético produzido na sequência do gesto ilustrado, apontado na transcrição pela barra vermelha.

\footnotetext{
${ }^{54}$ As sobrancelhas foram descritas utilizando o seguinte vocabulário, seguindo McCleary, Viotti e Leite (2010): i) $d f$ (posição neutra); ii) $r b$ (ambas as sobrancelhas levantadas); iii) $r r$ (sobrancelha direita levantada); iv) $r l$ (sobrancelha esquerda levantada); v) rf (sobrancelhas levantadas nas extremidades de dentro e a testa franzida); e $v i) f u$ (sobrancelhas franzidas).
} 


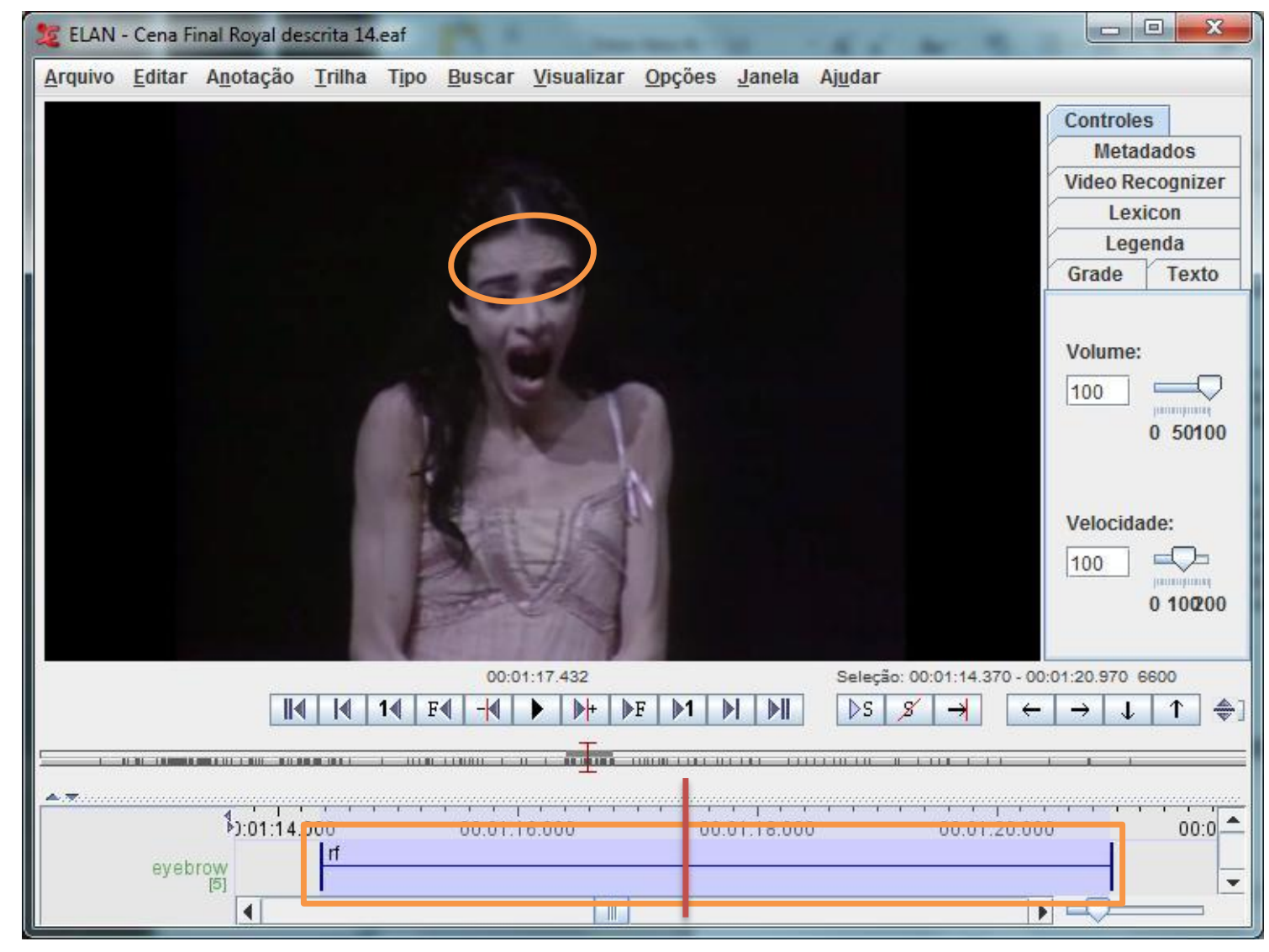

Figura 46. Exemplo da trilha sobrancelhas, retirado da transcrição da cena final na versão inglesa

\section{xii) Pálpebras}

Nessa trilha é anotada a descrição de posicionamento das pálpebras ${ }^{55}$. No exemplo da figura 47, as pálpebras encontram-se semicerradas no golpe e na retração parcial. Na fase de preparação, a posição das pálpebras não pode ser visualizada, pois a bailarina está com a cabeça abaixada, o queixo em direção ao torso. Apenas ao final da fase preparatória é possível observar com clareza os olhos da intérprete. Por vezes o processo de transcrição tem esse tipo de limitação, devido ao movimento de quem é observado em relação ao observador. A gravação do evento feita com mais de uma câmera busca minimizar esse tipo de transtorno.

${ }^{55} \mathrm{O}$ vocabulário utilizado para a descrição das pálpebras, apresentado em McCleary, Viotti e Leite (2010), foi: i) $d f$ (posição neutra, olhos abertos); ii) $w b$ (olhos bem abertos); iii) $w r$ (olho direito bem aberto); $i v) ~ w l$ (olho esquerdo bem aberto); $v$ ) $s b$ (olhos semicerrados); vi) $s r$ (olho direito semicerrado); vii) $s l$ (olho esquerdo semicerrado); viii) $c b$ (olhos fechados); $i x$ ) $c r$ (olho direito fechado); $x$ ) $c l$ (olho esquerdo fechado); $x i$ ) $t b$ (olhos fechados bem apertados); xii) $\operatorname{tr}$ (olho direito fechado bem apertado); e xiii) $t l$ (olho esquerdo fechado bem apertado). Movimentos de pálpebra associados a sinais manuais não foram utilizados. 


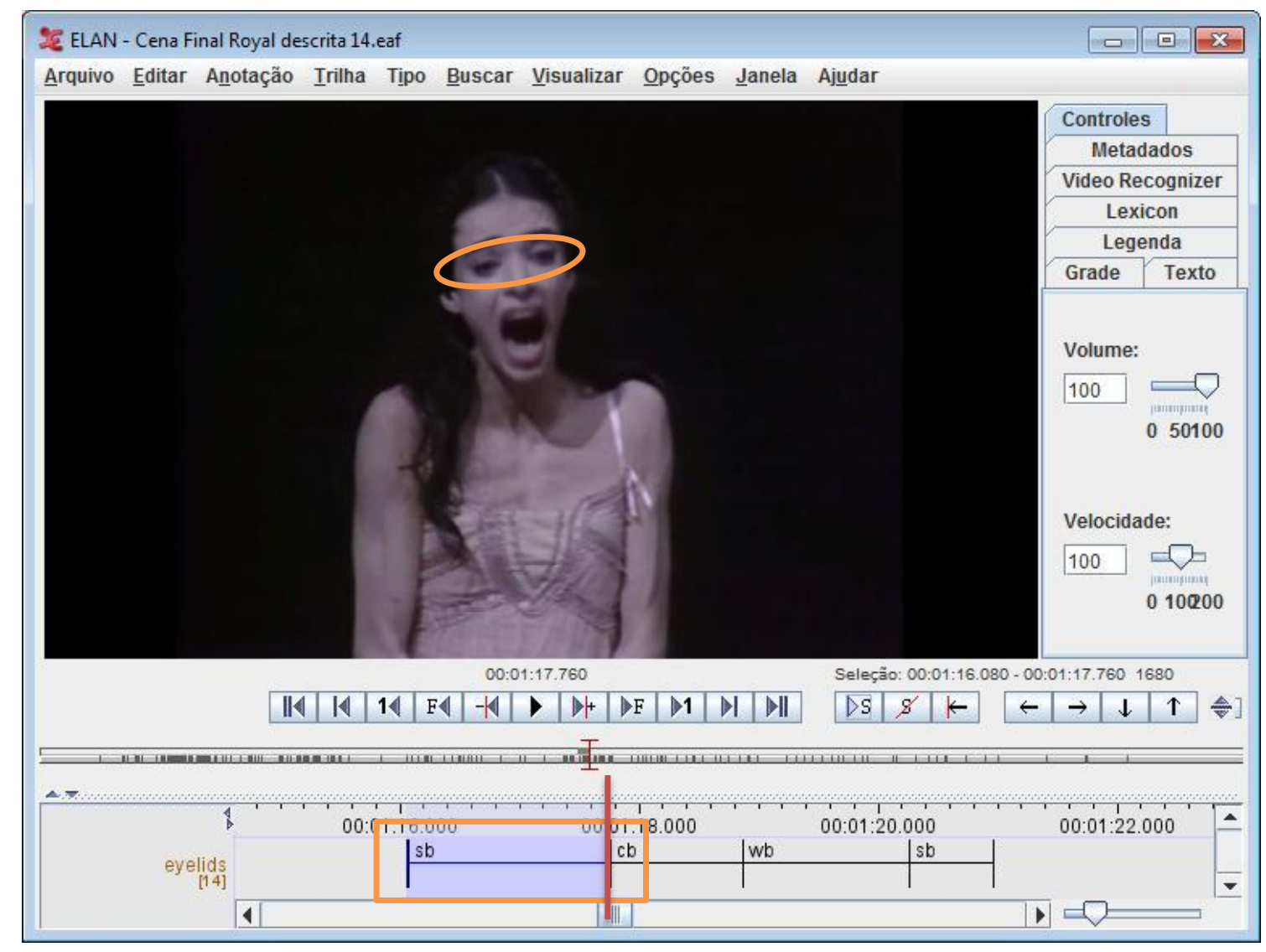

Figura 47. Exemplo da trilha pálpebras, retirado da transcrição da cena final na versão inglesa

\section{xiii) Olhar}

A descrição de direção do olhar é feita nessa trilha ${ }^{56}$. Na figura 48, a bailarina tem o olhar voltado para baixo, devido à posição da cabeça (inclinada para frente) e à configuração das pálpebras (semicerradas).

${ }^{56} \mathrm{O}$ olhar foi descrito a partir do seguinte vocabulário, que segue McCleary, Viotti e Leite (2010): i) $d f$ (olhar neutro); ii) ad (em direção ao interlocutor); iii) fr (olhar à distância); iv) $h d$ (em direção às mãos do próprio sinalizador); v) $h i$ (em direção à mão ativa do próprio sinalizador); vi) $h c$ (em direção à mão passiva do próprio sinalizador); vii) up (olhos para cima); viii) $d n$ (olhos para baixo); ix) le (olhos para a esquerda); $x$ ) ri (olhos para a direita); $x i$ ) no (sem foco); xii) ro (olhos girando); xiii) $c d$ (olhos para cima $\mathrm{e}$ para a direita); $x i v$ ) ce (olhos para cima e para a esquerda); $x v$ ) $b d$ (olhos para baixo e para a direita); $\mathrm{e}$ xvi) be (olhos para baixo e para a esquerda). 


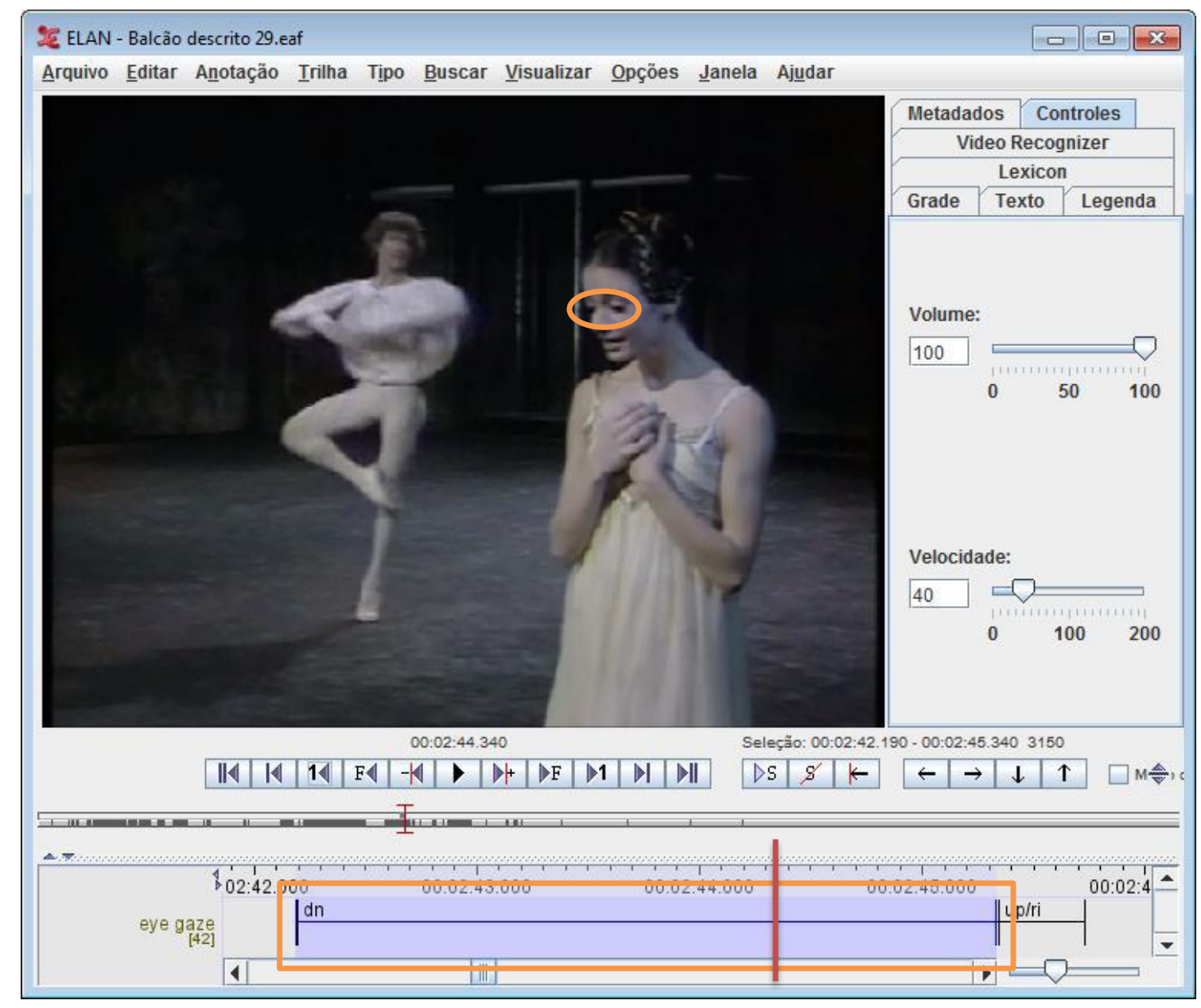

Figura 48. Exemplo da trilha olhar, retirado da transcrição da cena do balcão na versão inglesa

xiv) Boca

Nessa trilha é feita a descrição de configuração da boca ${ }^{57}$. No exemplo abaixo, a bailarina tem a boca ligeiramente aberta no ponto selecionado, indicado pela barra vermelha.

57 O vocabulário controlado apresentado em McCleary, Viotti e Leite (2010) para os gestos de boca consiste em vários itens. Como parte deles não foi pertinente para minha transcrição, reproduzo aqui somente os que foram utilizados: $i$ ) $d f$ (configuração da parte inferior da face neutra); ii) $d 01$ (cantos da boca bem esticados para fora mostrando os dentes); iii) d03 (boca ligeiramente aberta se movendo para uma posição com os dentes superiores sobre o lábio inferior); vi) d04 (boca aberta, com mandíbulas mais abertas do que em d03, se movendo para outra posição em que os dentes superiores encostam sobre o lábio inferior); vii) 101 (lábios se projetam para frente, com os dentes fechados e à mostra); viii) 104 (lábios contraídos); ix) 105 (lábios abertos e arredondados, a mandíbula inferior se move para baixo); $x$ ) 106 (lábios arredondados e ligeiramente abertos, mandíbula inferior se move para baixo); xi) $l 10$ (de lábios cerrados, com tensão, para lábios abertos, arredondados, a mandíbula inferior se move para baixo) ; xii) $l 11$ (de lábios cerrados, com tensão, para lábios abertos, a mandíbula inferior se move para baixo); xiii) $l 12$ (de lábios cerrados, com tensão, para lábios abertos, um pouco para os lados, os dentes ligeiramente afastados); xiv) $l 13$ (movendo-se de lábios cerrados , com tensão, para lábios abertos, bem 


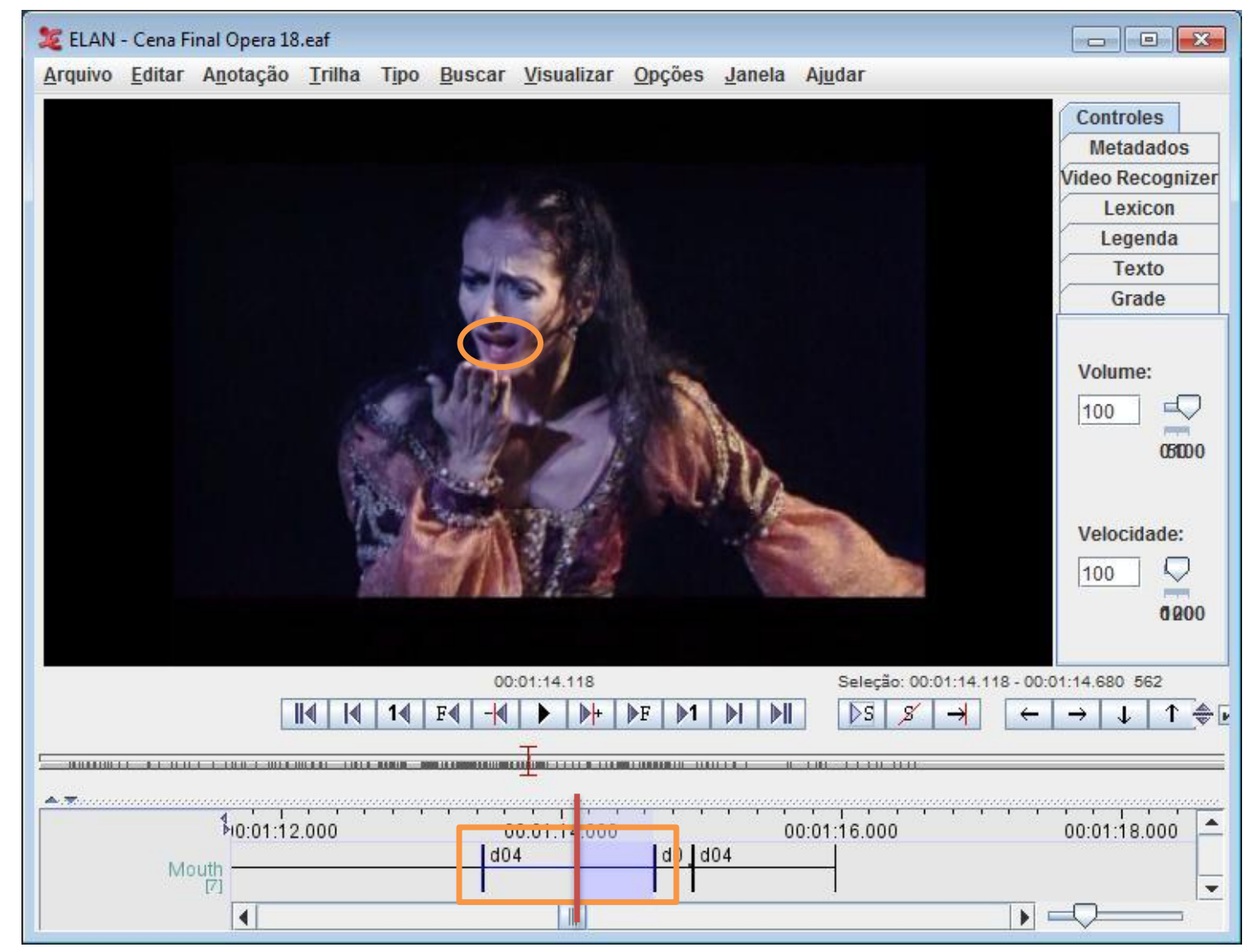

Figura 49. Exemplo da trilha boca, retirado da transcrição da cena final na versão francesa.

Utilizei o sinal gráfico de vírgula (,) para anotar a posição de diferentes articuladores simultaneamente observados em mãos e braços em um mesmo ponto do gesto. Por exemplo, no caso da trilha das mãos, são observadas as configurações de punho, dedos e posição da palma da mão. Essas observações são colocadas sequencialmente na anotação, separadas por vírgulas, como ilustrado abaixo.

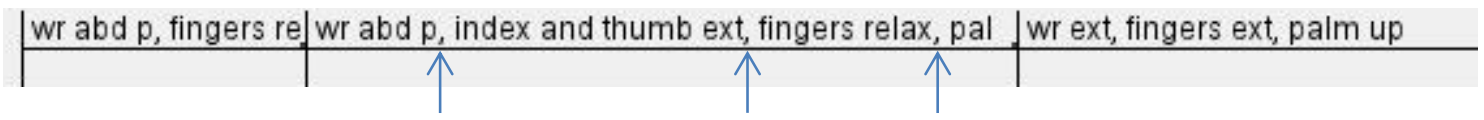

Figura 50. Anotações simultâneas em trilha de mão.

No caso dos braços, vírgulas são usadas para separar as anotações referentes à configuração do cotovelo, a angulação formada pela posição de braço e antebraço e sua posição com relação ao corpo do bailarino, como ilustrado a seguir.

para os lados, os dentes quase unidos); e $x v) l 15$ (movendo-se de lábios cerrados, com tensão, para cantos da boca bastante esticados para os lados e com os dentes à mostra). Eventualmente a configuração observada tinha alguma característica que não se encaixava perfeitamente nas categorias acima descritas. Nesses casos, ao lado do vocabulário controlado foi feita a anotação do traço diferencial, como, por exemplo, 101 no teeth, no qual a configuração 101 (lábios se projetam para frente, com os dentes fechados e à mostra) é preservada para os lábios, mas os dentes não estão à mostra. 
Figura 51. Anotações simultâneas em trilha de braço.

Para indicação de ocorrência de transição (movimento) de uma posição a outra dentro de uma mesma fase do gesto, usei o sinal gráfico de barra (/). Por exemplo, no caso do cotovelo passar de um ângulo de 90 graus em relação à flexão, para um ângulo de 45 graus, ou no caso do braço passar da lateral para trás do corpo.

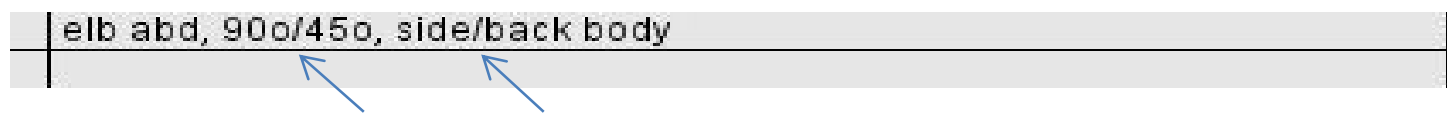

Figura 52. Anotação de transição em trilha de braço.

Considerando que a observação da cena do balcão contempla os dois participantes da cena, as 14 trilhas foram consideradas tanto para o intérprete de Romeu como para a intérprete de Julieta, de modo a possibilitar a descrição de gestos simultâneos, sobrepostos e individuais. Nas duas versões da cena final foi feita a transcrição apenas das intérpretes de Julieta.

A transcrição foi feita a partir de vídeo comercializado. Isso implica edição de imagens, o que é um fator complicador, pois, por vezes, interfere na observação do movimento a ser transcrito. Tanto a edição da versão inglesa quanto a da francesa foram bastante criteriosas no sentido de preservar a continuidade do movimento. No entanto, ainda é possível observar, em alguns momentos, a perda do movimento de um articulador na transição de um enquadramento mais fechado para outro mais aberto. Por se tratar de vídeos comerciais, não foi possível acessar o material bruto, ou seja, sem edição. Outro problema enfrentado diz respeito à observação de movimentos de um ou outro membro, ou de expressões faciais. Por vezes, o enquadramento não permitiu a visualização de detalhes. Alguns puderam ser inferidos pelas posições anterior ou posterior do ponto problemático. Outros não puderam ser transcritos. Mas para os fins da análise neste trabalho, foi possível pormenorizar e detalhar os movimentos de maneira bastante satisfatória.

É importante salientar que a transcrição contempla apenas os movimentos considerados gestuais, com base nos critérios apresentados. Os movimentos pertencentes à técnica de dança foram descritos apenas quando ocorreram simultaneamente com um gesto. No entanto, movimentos de translação no espaço não foram descritos. 
Uma das dificuldades encontradas diz respeito à transcrição de múltiplos articuladores, discutida por Kita et al. 1998. Há momentos em que diferentes articuladores apresentam diferentes fases na produção do gesto. Uma possível solução seria a inclusão de trilhas de fase para cada um dos articuladores. Por exemplo, há nos dados um gesto produzido por dois articuladores, cabeça e braço. A cabeça, no entanto, executa o movimento mais rápido que o braço, que utiliza toda a frase musical para produzir o gesto. As fases do gesto feito pelo braço estão ressaltadas pelo retângulo laranja, enquanto o retângulo vermelho destaca as fases do gesto produzido com a cabeça.

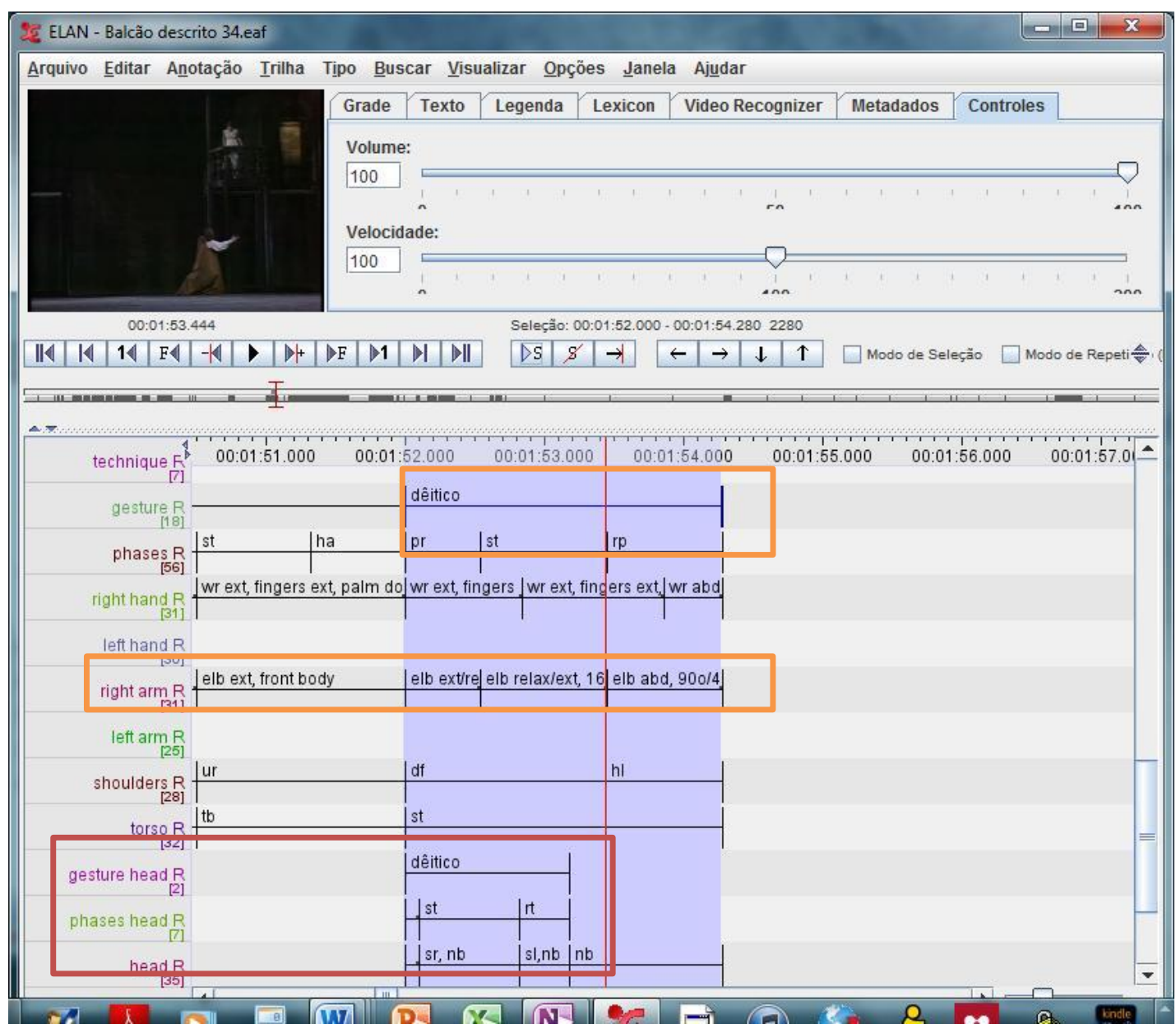

Figura 53. Gesto produzido por articuladores e diferentes fases.

Em outros momentos, diferentes articuladores produzem gestos diferentes, como, por exemplo, o momento em que as mãos estão na fase final de um gesto (indicado na transcrição pelo retângulo laranja) e o olhar se encontra na fase inicial de outro, que também é realizado com a cabeça (ressaltado pelo retângulo vermelho). Uma possível solução seria a inclusão de trilhas de gesto e trilhas de fase do gesto, para cada 
articulador, como ilustrado na figura abaixo, retirada da transcrição da cena do balcão na versão inglesa.

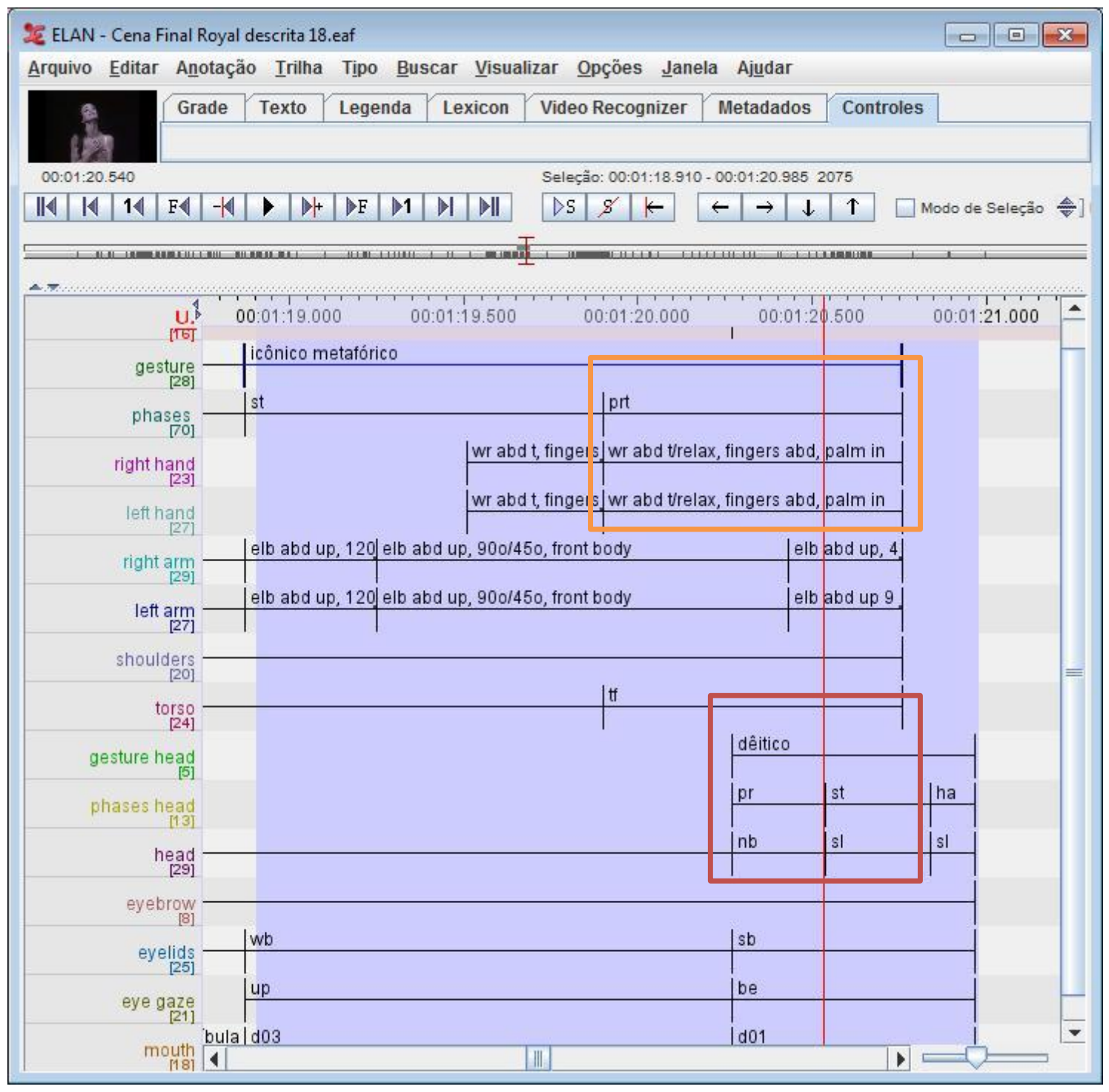

Figura 54. Diferentes gestos produzidos quase simultaneamente.

Essa sugestão também parece apropriada para a ocorrência de sincronia de fases para diferentes gestos, produzidos por diferentes articuladores. Por exemplo, temos dois gestos na figura abaixo, reproduzida a partir da transcrição da cena do balcão: um produzido pela cabeça e olhar (ressaltado na transcrição pelos retângulos vermelhos), e outro produzido pelos braços e mãos da intérprete feminina (ressaltado pelos retângulos laranjas). Apesar de serem gestos produzidos por diferentes articuladores, suas fases estão temporalmente sincronizadas. 


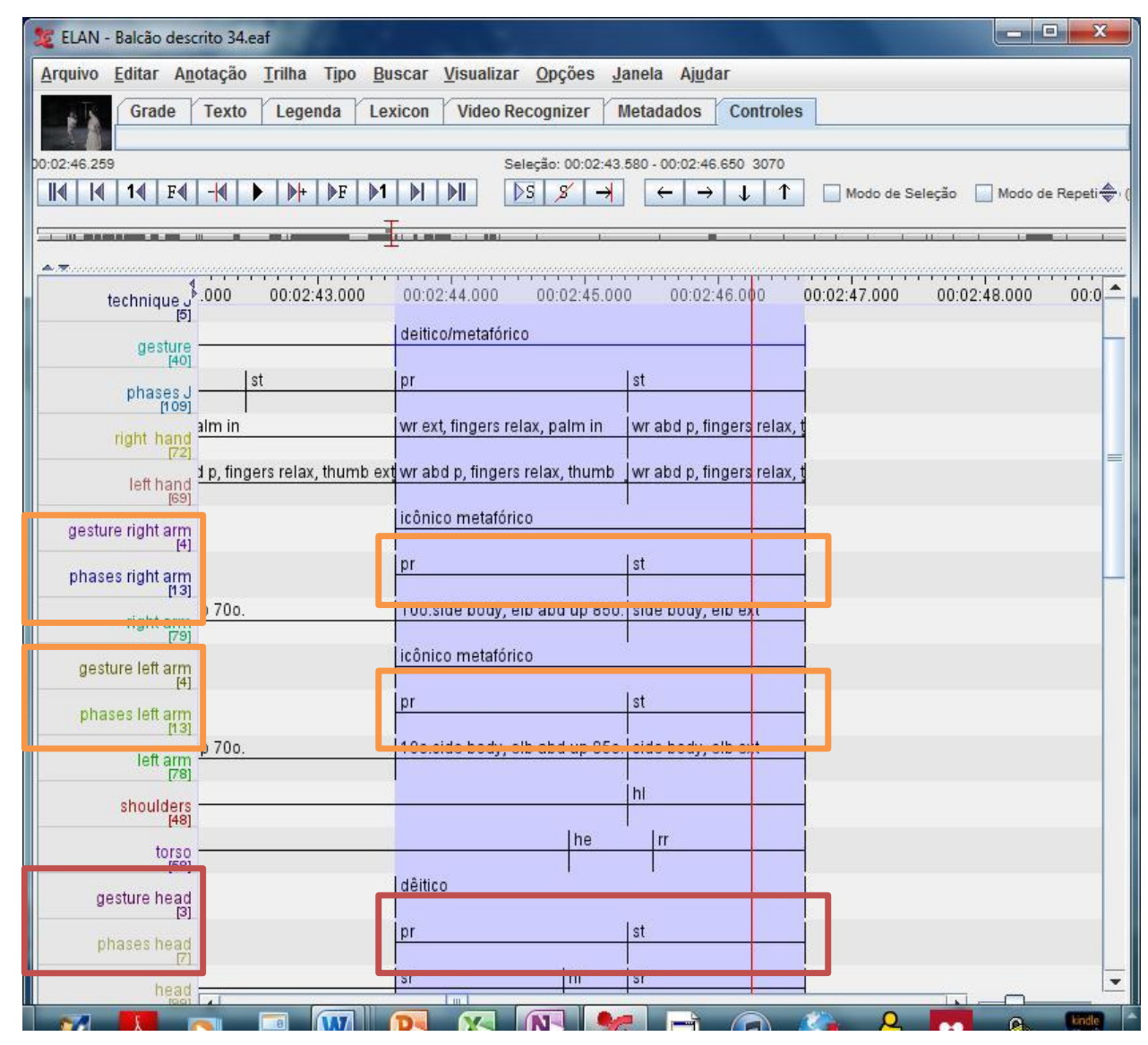

Figura 55. Diferentes gestos produzidos com fases iguais.

Esses são exemplos do uso de uma trilha de gesto e fases do gesto específicas para cada articulador. Essas soluções parecem apropriadas, ainda que tenham sido aplicadas a apenas alguns gestos a título de teste. Sua aplicação sobre todo o corpus, no entanto, comprometeria o prazo de finalização da pesquisa e foram deixadas para uma fase subsequente do trabalho. Também em uma fase futura, o vocabulário controlado adaptado para as trilhas de mãos e por mim proposto para as trilhas de braços deverá ser revisto para buscar atingir a concisão alcançada por McCleary, Viotti e Leite (2010). 


\section{Capítulo 3 Análise dos dados}

A dança é um sistema semiótico sincrético, isto é, integra diversos sistemas semióticos, articulando diversos níveis de significado. Esses sistemas agregam diferentes signos, com diferentes possibilidades interpretativas, fazendo com que a construção do sentido na dança, assim como na língua, se torne dependente da experiência individual do espectador (Hanna 1990, p.358). Essa experiência individual está baseada em um conhecimento de mundo, ou conhecimento enciclopédico, que é construído a partir da interação de cada pessoa com o mundo, e de percepções culturais compartilhadas pelo grupo social no qual o espectador se insere. Ele é responsável pelo reconhecimento de elementos pertencentes a uma situação, como, por exemplo, uma situação de compra e venda, que inclui características reconhecíveis como um vendedor e um comprador, uma mercadoria e uma moeda (Fillmore 1977). Esse reconhecimento de uma situação, seja ela presente, passada ou futura, constitui o fundo comum, que possibilita a comunicação, já que estabelece pressupostos a partir dos quais a interação se torna possível (Clark 1996). As percepções culturais, parte do conhecimento enciclopédico, e, portanto, do fundo comum, incluem conceitos que um grupo tem em relação a espaço, tempo, energia, mente e corpo, que servirão como referentes em dança (Hanna 1987 [1979]). A composição da dança traz esses elementos individuais e culturais da parte dos vários sujeitos envolvidos em sua concepção e execução, que contribuem para dar visibilidade ao processo de conceitualização. Esta análise toma essa perspectiva da composição, atendo-se, no entanto, à observação da relação entre movimentos técnicos, de um lado, e movimentos pantomímicos e gestuais, de outro, sem levar em consideração outros sistemas semióticos participantes da narrativa dançada, como figurino, cenário, iluminação, música, etc.

A seguir, apresento os dados coletados das cenas observadas. Para isso, sigo a divisão da categorização gestual proposta no capítulo 1, seção 1.2.2, que inclui gestos dêiticos, icônicos imagéticos, icônicos diagramáticos, icônicos metafóricos, coesivos e batidas. É preciso levar em conta que a exemplificação das cenas se dará através de fotografias, tornando estático o que originalmente é produzido em movimento ${ }^{58}$. Uma tentativa de minimizar essa dificuldade é a apresentação de sequências de fotos que

${ }^{58}$ A versão digitalizada traz os links para os filmes das partes analisadas. 
retratam as frases gestuais. Em alguns exemplos, no entanto, as fotos tendem a reproduzir apenas um ponto da fase expressiva do gesto, chamada golpe ${ }^{59}$.

Escolhi apresentar, primeiramente, os dados referentes à cena principal desta análise, a cena do balcão na versão inglesa, para depois introduzir os dados das cenas de controle. Essa opção se deve ao fato de a cena principal apresentar diversas instâncias de sequências técnicas e pantomímicas com elementos gestuais, ao passo que as cenas de controle apresentam, quase exclusivamente, sequências pantomímicas com elementos gestuais. Em relação às cenas de controle, optei por comentar primeiro a cena final da versão inglesa, por se tratar da mesma versão da cena do balcão, para depois incluir os dados da cena final na versão francesa. Na medida do possível, a observação das duas versões da cena final foi feita levando em consideração um aspecto contrastivo entre as versões, de modo a demonstrar diferentes soluções gestuais para uma mesma situação. Esse contraste entre as cenas traz à tona a questão do contexto, não apenas como meio físico no qual os bailarinos se encontram, mas também do contexto construído através da linha narrativa e da elaboração das personagens, com suas características individuais. Apenas em um caso utilizei outra fonte de referência para o contraste, que é a cena do balcão coreografada por Kenneth MacMillan e interpretada por Margot Fonteyn e Rudolf Nureyev ${ }^{60}$.

Apresento as categorias gestuais na seguinte ordem: analiso, primeiramente, os gestos dêiticos; sigo com as considerações sobre os gestos icônicos imagéticos; discuto os gestos icônicos diagramáticos, seguidos dos gestos icônicos metafóricos. Finalizo a apresentação dos dados com gestos coesivos e batidas. Finalmente, analiso a sobreposição de signos gestuais nos dados apresentados.

\subsection{Dêiticos}

Essa categoria deriva do conceito linguístico de dêixis, ligada ao estabelecimento das pessoas, do espaço e do tempo do discurso. Um exemplo linguístico de dêixis são os pronomes chamados pessoais, ligados às relações de pessoa no verbo. Benveniste (1966) estabelece a distinção entre as pessoas do discurso, eu e você, de instância única, da não-pessoa, elelela, ligada a uma infinidade de sujeitos ou a nenhum, no caso da expressão impessoal. As pessoas de instância única dividem-se em

\footnotetext{
${ }^{59}$ Essa divisão corresponde às fases do gesto mencionadas no capítulo 2, seção 2.2.2, item iii .

${ }^{60}$ A versão citada foi obtida através do endereço http://www.youtube.com/watch?v=D55WaK8Og1A.
} 
pessoa subjetiva (eu) marca de interioridade, que corresponde cada vez a um ser único (pg. 278), e pessoa não-subjetiva (você), marca de exterioridade, estabelecida, aparte de si, pelo eu. No caso deste trabalho, como o material observado é uma narrativa, uma história está sendo contada por uma pessoa a outras. Assim, há apontamentos que são realizados para que a plateia possa perceber a intenção comunicativa do coreógrafo e/ou dos bailarinos, ou seja, são realizados não no contexto de comunicação entre as personagens, mas para comunicação entre o coreógrafo e plateia, mediado pelos intérpretes. Esses apontamentos estabelecem para a plateia quem se identifica como eu e quem está identificado com você no discurso dançado.

As pessoas do discurso verbal têm, ainda, o caráter de reversibilidade, ou seja, são utilizadas alternadamente pelos interlocutores na situação de enunciação. O discurso dançado também apresenta essa alternância, como se pode observar nos dois primeiros exemplos analisados. No caso do estabelecimento do espaço e do tempo, linguisticamente eles se fazem através do uso dos advérbios aqui e agora, lá, ontem, etc., tomando por referência o momento da enunciação. A dança se instancia no presente, assim, quando um bailarino ou bailarina institui o $\mathrm{eu}$ e o $\mathrm{tu}$ do discurso dançado, ele também estabelece o tempo presente (agora) e o espaço a partir do qual ele enuncia (aqui).

Os gestos dêiticos são os apontamentos que acompanham a fala e indicam referentes do discurso, presentes ou não no momento da enunciação - o $e u$, o você e o ele/ela. Em dança, o apontamento parece ser realizado na maior parte das vezes com o olhar, com o posicionamento da cabeça e do corpo indicando a direção em que se encontra o referente não de $1^{\mathrm{a}}$. pessoa, ou seja, o você ou o elelela. Esse mesmo apontamento também é usado para estabelecer o tempo e o espaço do discurso, como apontado acima. A preponderância do olhar e da indicação de direção com a cabeça e/ou o corpo na dança sobre o apontamento com as mãos, bastante comum nos gestos que acompanham a fala, talvez se deva ao fato de a posição de apontamento com a mão poder ser eventualmente confundida, à distância, com a postura de braços do arabesque, dependendo da posição do corpo. Reforçar o olhar com a direção do corpo passa a ser uma estratégia para facilitar a leitura por parte da plateia e para evitar possíveis ambiguidades. 
Além disso, em dança, o gesto dêitico é usado não apenas para instituir as personagens, nas pessoas dos bailarinos, mas também para localizar o espaço a partir do qual o bailarino "fala". No exemplo abaixo (figura 56), retirado da cena do balcão, Julieta se encontra divagando distraída na sacada quando Romeu entra em cena e se apresenta a ela, por meio de um gesto de cabeça e olhar. Ao direcionar o olhar para a sacada, inclinando a cabeça levemente para trás, e levantando o olhar, Romeu institui tanto os sujeitos (eu e você), quanto o espaço (aqui) e o tempo (agora) do discurso. O bailarino encontra-se na ponta esquerda da parte anterior do palco, em diagonal com relação à sacada, localizada na ponta direita da parte posterior do palco. A direção do olhar pode, então, ser acompanhada pela plateia.

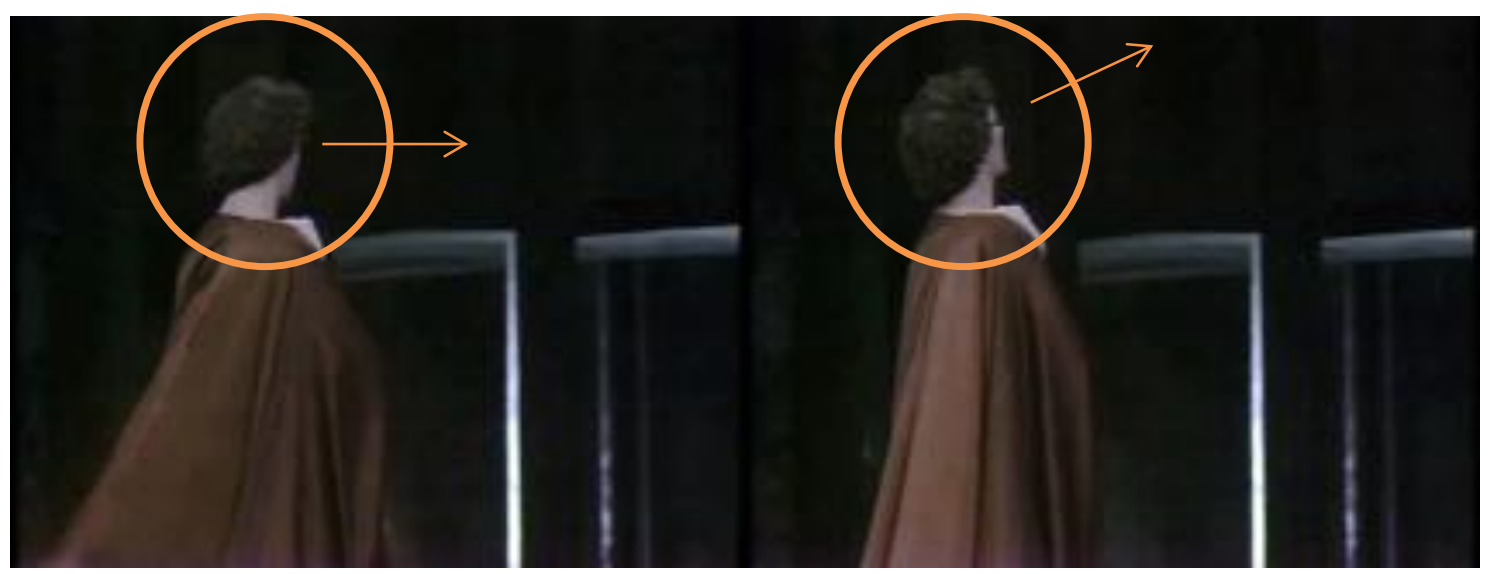

Figura 56. Exemplo de gesto dêitico com cabeça e olhar.

..1.....|Videos\Gestos Dissertação\Dêitico 1.wmv

Logo depois, ele pede a ela que desça para encontrá-lo, através de outro gesto dêitico (figura 57). O apontamento é realizado pela cabeça e pelo olhar de Romeu, que indicam a escada para que Julieta possa vir ao seu encontro. O bailarino está logo abaixo da sacada onde Julieta se encontra, na porção direita superior, próximo ao ponto central do fundo do palco. A escada está localizada na parte direita anterior do tablado, próximo às coxias. O movimento de cabeça de Romeu é feito a partir da posição inclinada para trás da cabeça e direcionada para frente. A cabeça vira para a direita e volta ao ponto inicial, traçando um percurso de noventa graus em semicírculo tanto para a ida como para a volta. Não é possível acompanhar o olhar durante todo o percurso, mas a posição das pálpebras na fase expressiva do movimento me permite inferir a direção do olhar. O movimento da cabeça e do olhar é acompanhado por um movimento mais lento do braço direito. Ele também traça um semicírculo no espaço, partindo da posição final do gesto anterior, estendido para frente e para cima, em direção a Julieta. No entanto, não há o percurso de retorno à posição inicial, como no caso da cabeça. $\mathrm{O}$ 
movimento do braço termina com o apontamento para a escada. Esse gesto dêitico, além de indicar uma direção (a ponta direita anterior do palco) e apontar para um referente (a escada), abre a possibilidade de entendimento de um pedido ou convite de Romeu para que Julieta desça ao pátio. Nesse caso, o gesto passa a ser icônico diagramático, ao estabelecer uma relação metonímica entre a escada e sua função ${ }^{61}$. Estendendo a possibilidade de conceitualização do gesto do braço, o apontamento passa a ser a expressão concreta para algo abstrato, como um convite ou pedido, podendo ser entendido, assim, como um gesto icônico metafórico.

${ }^{61}$ Gestos icônicos diagramáticos serão apresentados mais adiante, no item 3.3. 

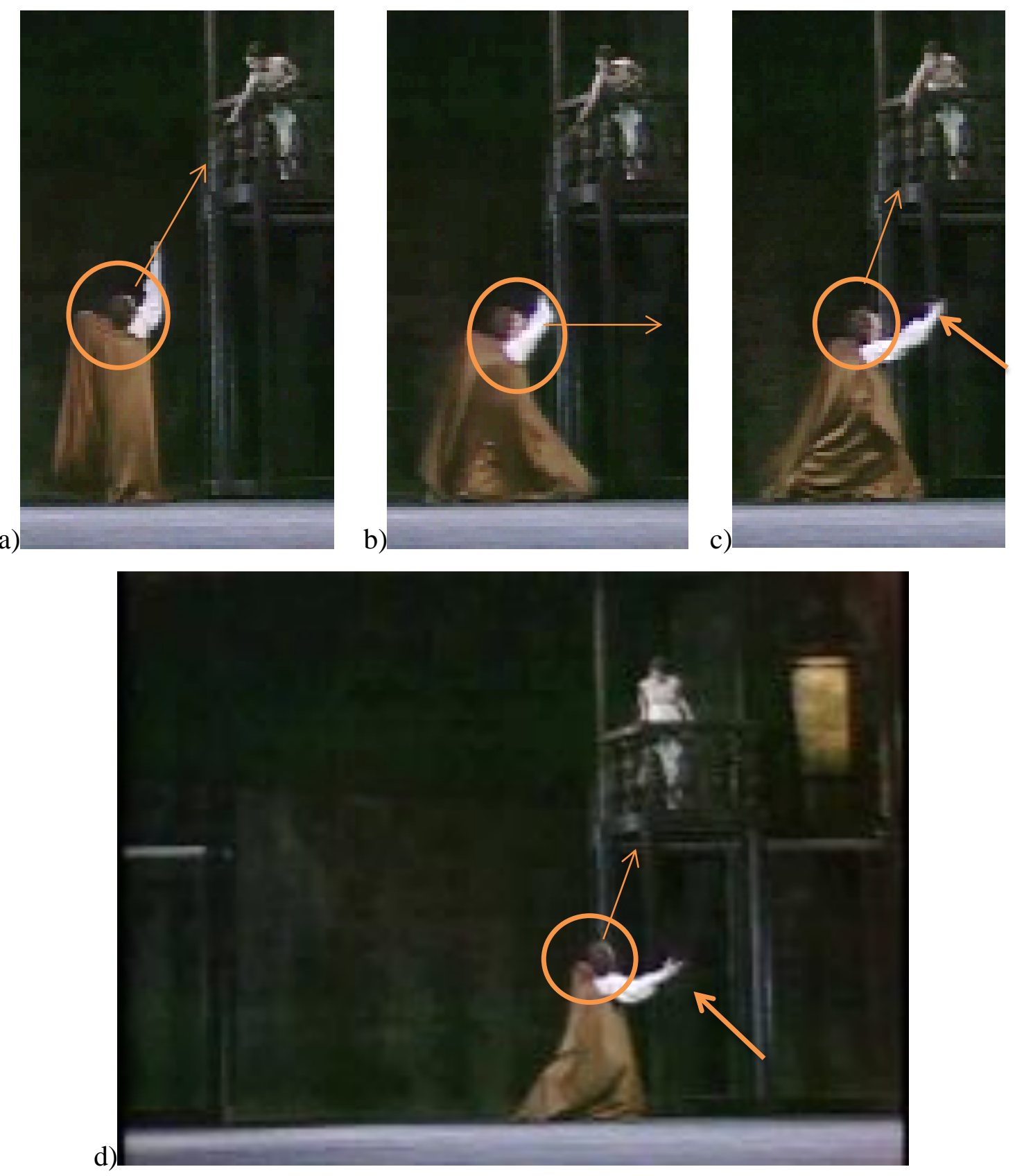

Figura 57. Exemplo de gesto dêitico com cabeça, olhar e braço (Romeu). a) posição inicial; b) gesto realizado com a cabeça; c) volta da cabeça e continuação do braço; d) posição final.

..1..... Videos/Gestos Dissertação|Dêitico 2.wmv

Outro exemplo de gesto dêitico (figura 58), retirado da mesma cena, é feito por Julieta através da direção do corpo, da cabeça e do olhar. Ele é realizado quando Romeu termina de dançar uma sequência coreográfica e faz um gesto metafórico, com a palma da mão direita voltada para cima e o braço estendido em sua direção, possivelmente oferecendo-lhe um objeto abstrato. Julieta traz os braços com os cotovelos estendidos ao lado do corpo, voltados para frente, assim como as palmas das mãos, em um gesto metafórico, como se ela mesma fosse um objeto a ser oferecido a Romeu (a). 


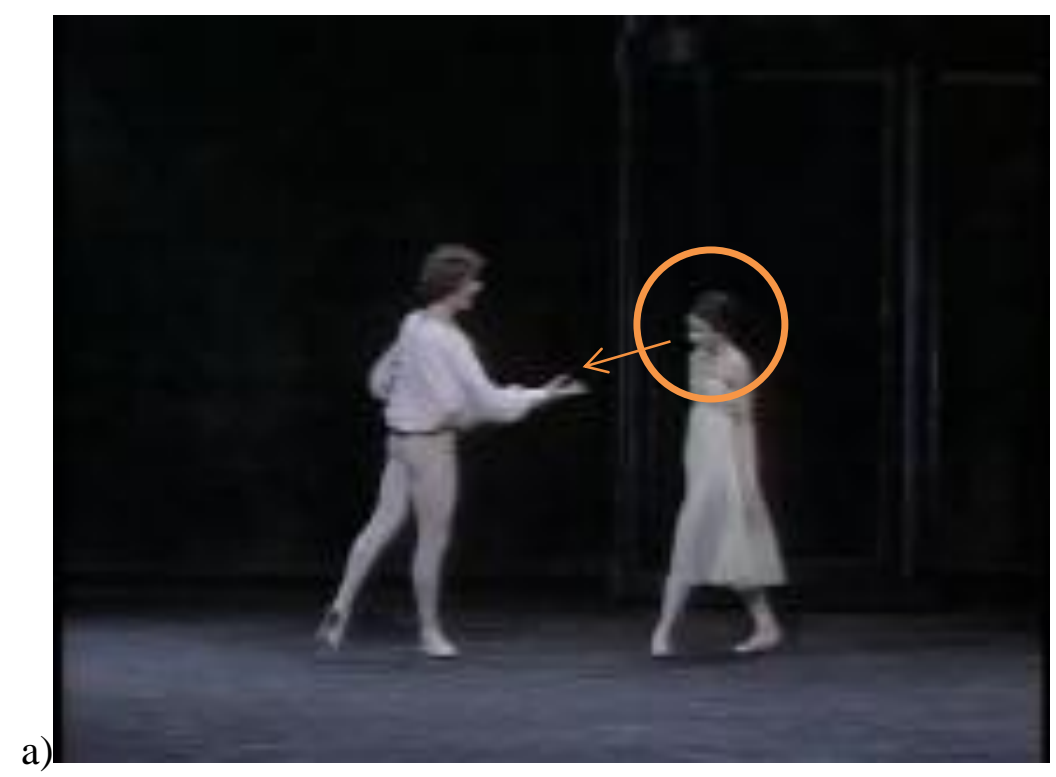

Figura 58. Exemplo de gesto dêitico com cabeça e olhar (Julieta). a) posição inicial

Ao mesmo tempo em que se aproxima da mão estendida de Romeu, caminhando, Julieta inclina a cabeça e o olhar, para baixo, em direção à palma da mão do bailarino (b). No início do gesto, o corpo de Julieta está de frente para Romeu. Ao realizar o gesto dêitico, os ombros e quadris giram ligeiramente para a direita, colocando-a em diagonal com relação a Romeu. Ela realiza o gesto de apontamento para a palma da mão aberta para cima, ao mesmo tempo em que realiza novamente o gesto metafórico com os braços ${ }^{62}$.

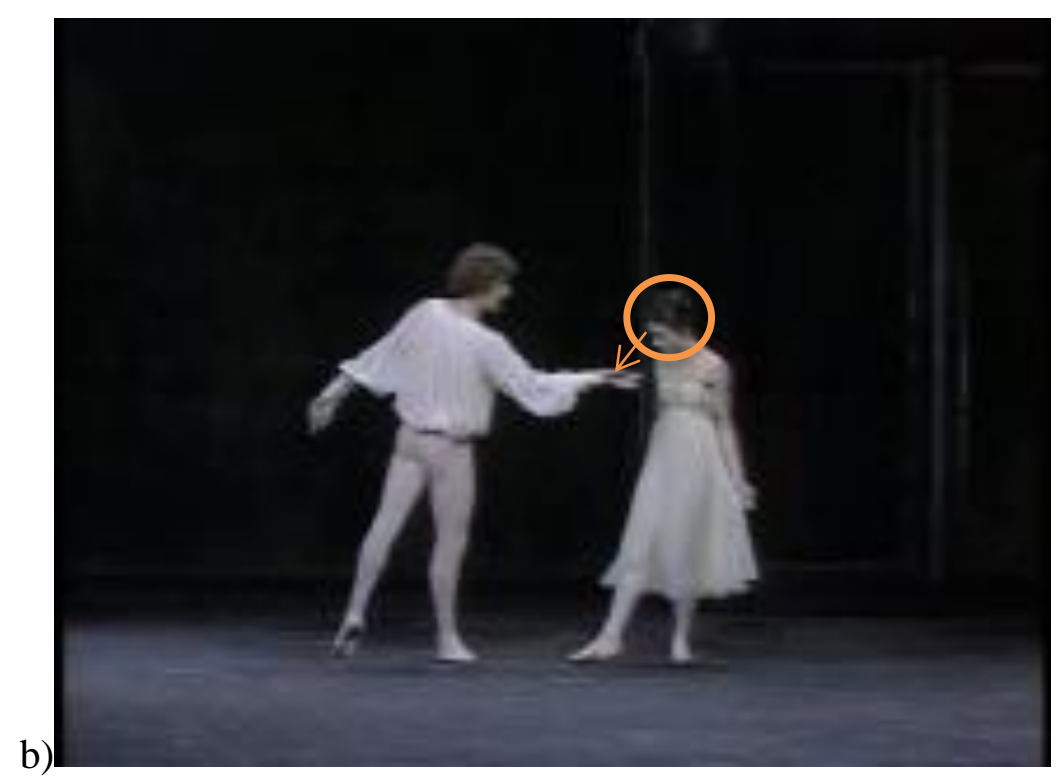

Figura 58. (cont.) Exemplo de gesto dêitico com cabeça e olhar (Julieta). b) posição final. ........Videos \Gestos Dissertação|Dêitico 3b.wmv

${ }^{62}$ Apesar de os dois gestos serem produzidos por diferentes articuladores, as fases dos gestos estão sincronizadas, ou seja, os gestos são simultâneos. 
Um exemplo de gesto dêitico realizado durante uma sequência coreográfica está ilustrado abaixo. Ao terminar a sequência piqué ${ }^{63} /$ pirouette (a) em um arabesque croisé, Romeu, que está mais próximo do centro do palco, aponta a cabeça e o olhar para Julieta (b), que está na parte anterior do palco, à direita. Nos passos precedentes, e nos seguintes, o olhar não está apontado para a bailarina. Ocorre uma conjugação do gesto dêitico da cabeça e do olhar com o gesto diagramático, que reproduz parte do movimento de chamar alguém, realizado com o braço direito e a mão (c) ${ }^{64}$. No entanto, diferentemente do exemplo anterior em que havia uma sobreposição de gestos e de fases de gesto, aqui os diferentes articuladores produzem gestos distintos com fases diferentes, ainda que ambos aconteçam no mesmo intervalo de tempo.
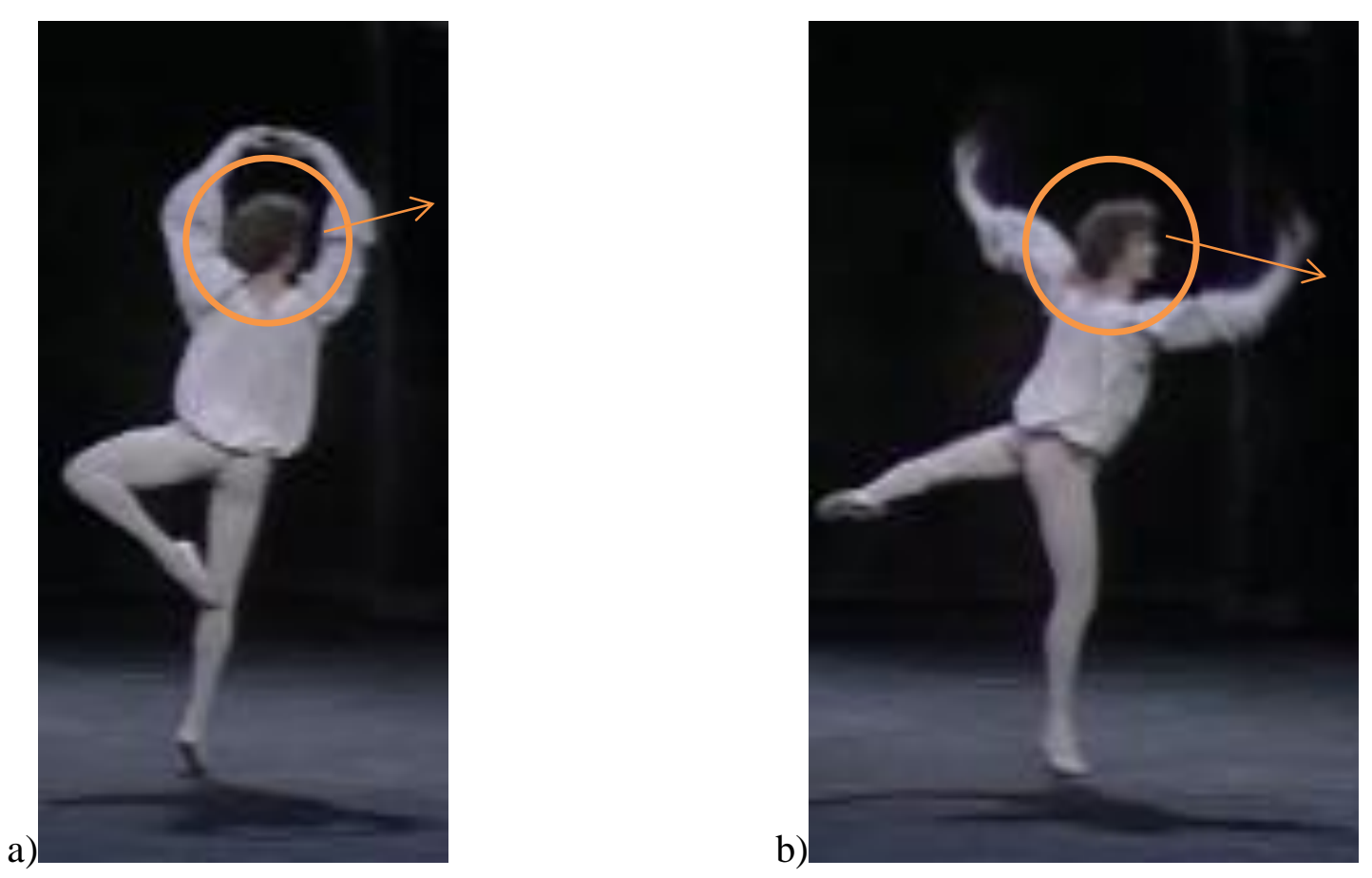

\footnotetext{
${ }^{63}$ Piqué é o passo em que uma perna é projetada para longe do corpo (à frente, ao lado ou atrás dele), com posterior transferência de peso para um relevé (cf. figura 16) sobre a perna que estava no ar. Após a transferência, é possível executar um passé, um arabesque, um attitude, entre outras posições com configuração de apoio sobre uma perna enquanto a outra faz um desenho no ar.

${ }^{64}$ Esse gesto será analisado mais detalhadamente na seção 3.3.
} 


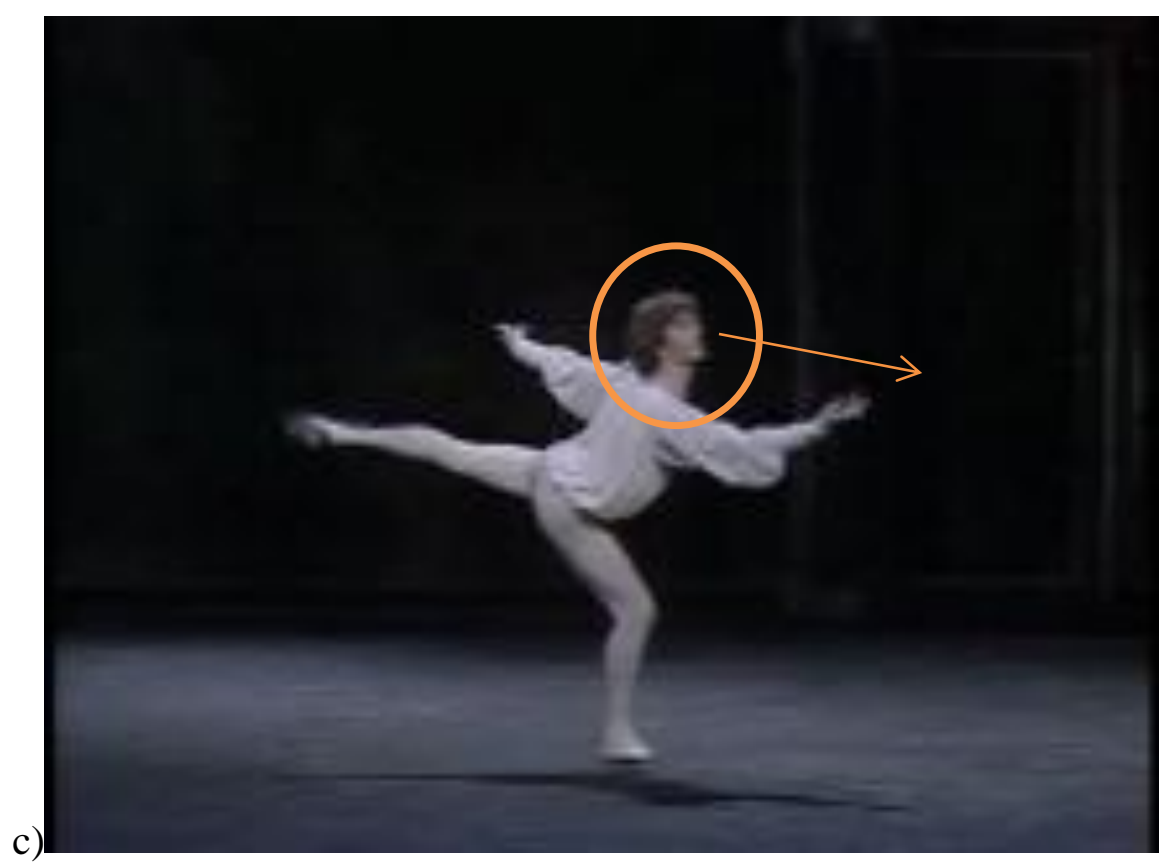

Figura 59. Gesto dêitico em sequência coreográfica. a) posição inicial; b) gesto dêitico feito com a cabeça, c) posição final.

..1.....Videos \Gestos Dissertação\Dêitico 4.wmv

Nesse exemplo é possível observar a distinção e interação entre o nível técnico e o nível gestual, já que um gesto dêitico e um gesto icônico diagramático acontecem durante a execução de um passo técnico. O gesto dêitico aponta para a direção em que o passo vai ser executado, que corresponde à direção em que a bailarina se encontra. Já o gesto diagramático, repetido em vários pontos dessa mesma sequência (até culminar com um gesto icônico metafórico), remete à reprodução de parte do gesto de chamar alguém para perto de si, que será explorado em maior detalhe na seção 3.3. Ou seja, movimentos que não correspondem a movimentos estabelecidos como parte da técnica de dança são produzidos junto com o movimento técnico.

Em outra sequência coreográfica, a mudança de olhar acontece antes da execução do cabriole, salto em que uma perna eleva-se em arabesque e a perna de base une-se a ela no ar, ocorrendo uma batida da face posterior da perna de base que se eleva com a parte anterior da perna em arabesque. É possível perceber, pela sequência fotográfica, que a cabeça de Romeu se volta para Julieta (b) na transição entre o passo anterior (a) e o cabriole (c). O bailarino executa o passo anterior de perfil para o público, tendo como referência frontal as coxias situadas no lado esquerdo do palco. $\mathrm{O}$ cabriole é executado de frente para a diagonal direita anterior, onde está a bailarina. $\mathrm{O}$ gesto dêitico acontece antes da troca de direção do corpo, como se Romeu estivesse querendo localizar Julieta para poder fazer o salto para ela. Essa relação guarda alguma 
semelhança com a relação presente nos balés de corte que eram dançados para o rei e a rainha. Com relação à plateia, o olhar de Romeu traz Julieta para a cena, já que toda a sequência anterior é feita sem referência à personagem feminina, posicionada na parte anterior do lado direito do palco.

a)
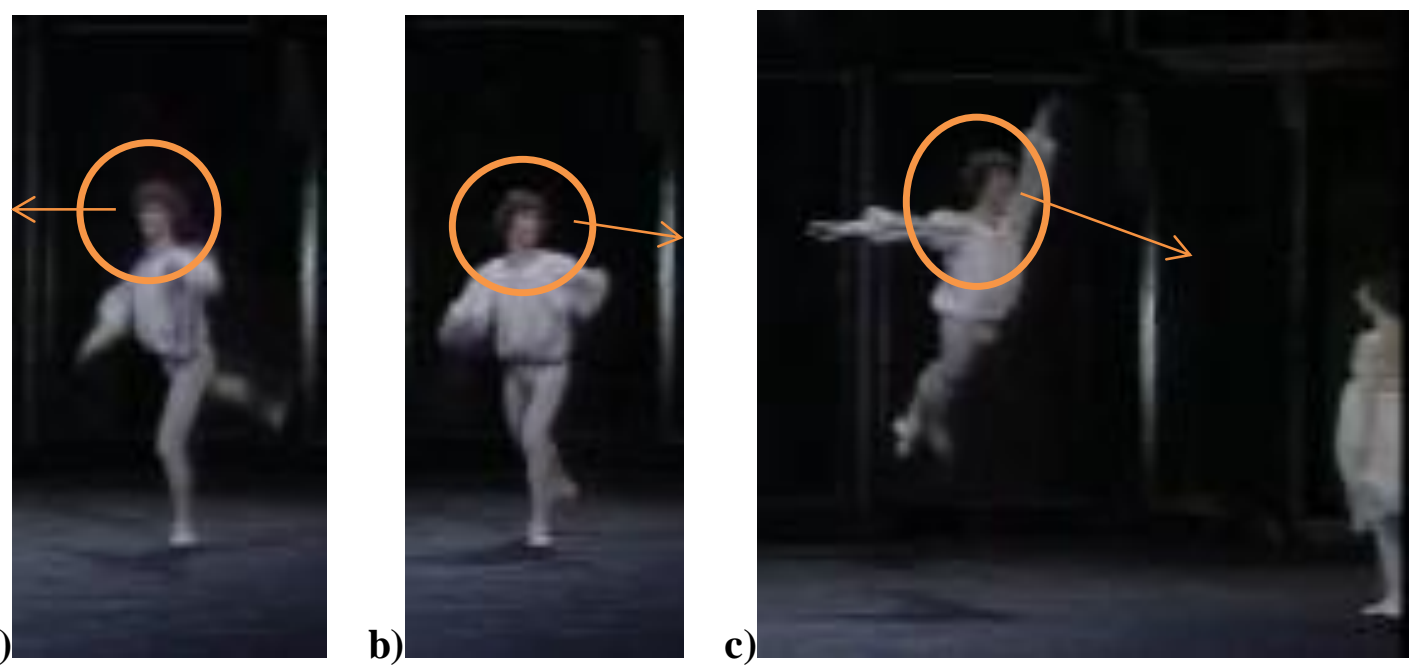

Figura 60. Exemplo de gesto dêitico em sequência coreográfica. a) posição anterior; b) gesto dêitico realizado com o olhar e a cabeça; c) gesto dêitico realizado com cabriole derriére.

..1..1.. Videos \Gestos Dissertação|Dêitico 5.wmv

Novamente é possível perceber a distinção entre os níveis técnico e gestual, ainda que o gesto esteja sendo realizado em um ponto de transição entre passos técnicos.

Há exemplos de gestos dêiticos, utilizados para o estabelecimento do espaço onde a cena se desenvolve, retirados da cena final tanto na versão inglesa quanto na francesa, em que fundamentalmente encontram-se pantomimas e não passos técnicos. No texto original de Shakespeare, na cena final, ao acordar, Julieta exclama: "I do remember well where I should be, And there I am. Where is my Romeo? "65. No discurso dançado, o lugar onde Julieta acha que Romeu deve estar é explorado, primeiro com o olhar, e depois com deslocamentos pelo espaço. Na versão coreografada por MacMillan ocorrem três momentos em que Julieta, que está sobre a tumba localizada na parte central do fundo do palco, estabelece o entorno. Ela o faz através do reconhecimento de um apoio (a), do entendimento do limite desse apoio (b) e do reconhecimento da cripta (c). Esse momento marca o despertar de Julieta, após o estado vegetativo induzido pela poção de Frei Lourenço.

65 "Lembro-me bem de onde devo estar, E aqui estou. Onde está meu Romeu?" (tradução Barbara Heliodora, em Tragédias e comédias sombrias: obras completas William Shakespeare). Texto integral em inglês obtido em http://shakespeare.mit.edu/romeo_juliet/full.html. 

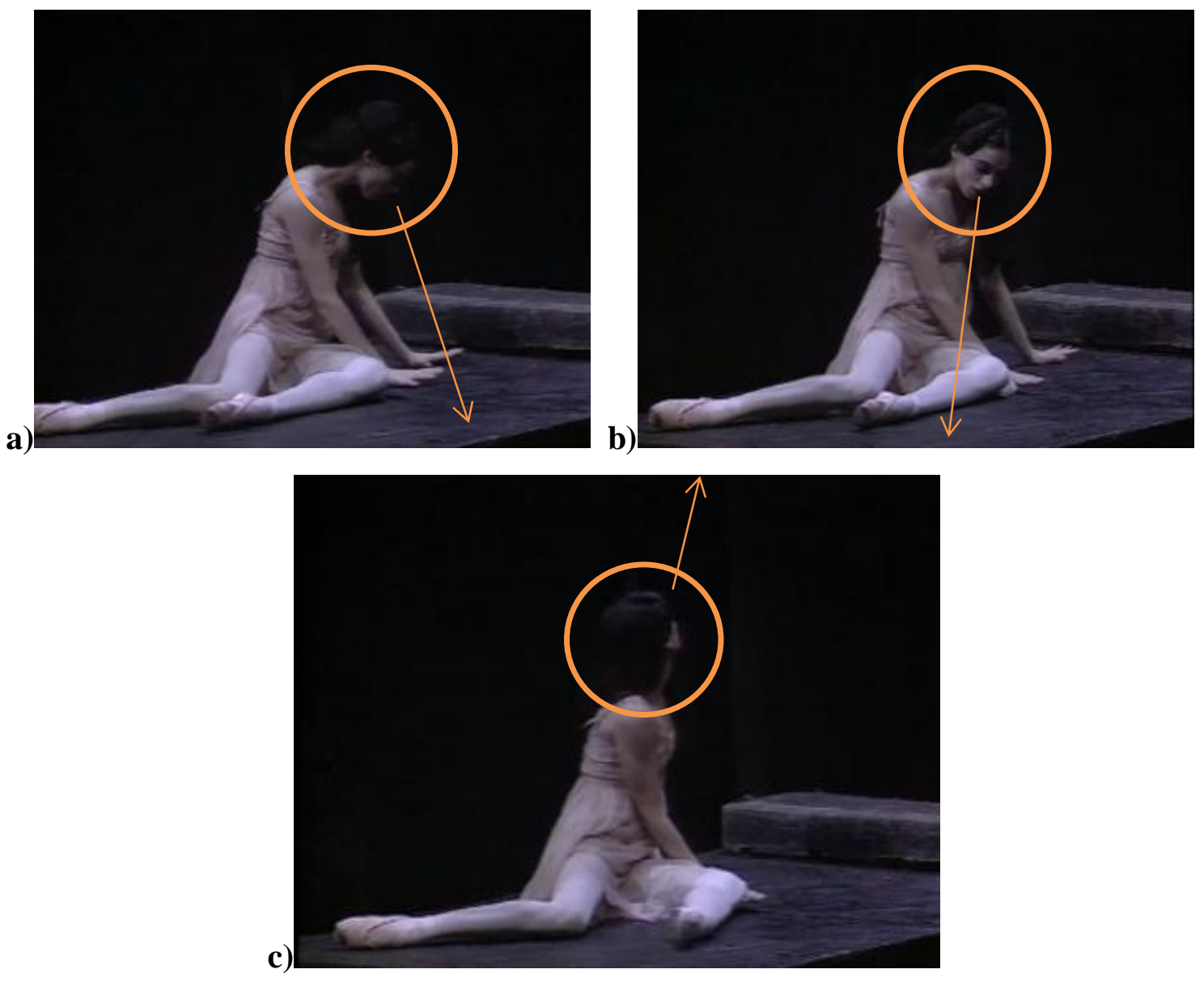

Figura 61. Gestos dêiticos na cena final, versão inglesa. a) cabeça e olhar para diagonal direita fundo; b) cabeça e olhar para diagonal direita frente.

.......Videos IGestos DissertacãolDêitico 6.wmv

Em (a) e (b), os ombros acompanham a cabeça, ou seja, no primeiro momento corpo e cabeça estão alinhados e virados para a diagonal direita em direção ao fundo do palco, e no segundo momento cabeça e ombros viram-se para a lateral e o queixo quase atinge a diagonal direita à frente do palco. Em ambos os momentos a cabeça e o olhar estão voltados para o apoio. Em (c), os ombros retomam a diagonal direita, como em (a), e a cabeça segue até a diagonal esquerda em direção ao fundo do palco, com o queixo levemente levantado e a cabeça inclinada para trás. A direção do olhar e da cabeça ganha o reforço da direção do corpo, que se inclina para frente quando o olhar está voltado para baixo, vira-se para frente quando o olhar e a cabeça o fazem, e volta-se para o fundo quando a cabeça assume a posição em (c).

Na versão francesa, o estabelecimento do entorno se dá em quatro movimentos: em (a), logo depois de acordar, Julieta senta-se e olha para frente, com a cabeça virada 
para o lado esquerdo do palco e de perfil para o público. O corpo está virado para a diagonal esquerda e as pernas dobradas, a esquerda mais flexionada que a direita, mantendo a mesma diagonal do corpo. Os braços encontram-se flexionados à frente do corpo, com as mãos levemente apoiadas sobre o pescoço. Em (b), o olhar eleva-se para a diagonal alta, ainda para frente. A cabeça inclina-se para trás, mantendo o perfil para a plateia, e o corpo e as pernas mantêm a posição diagonal do gesto anterior.
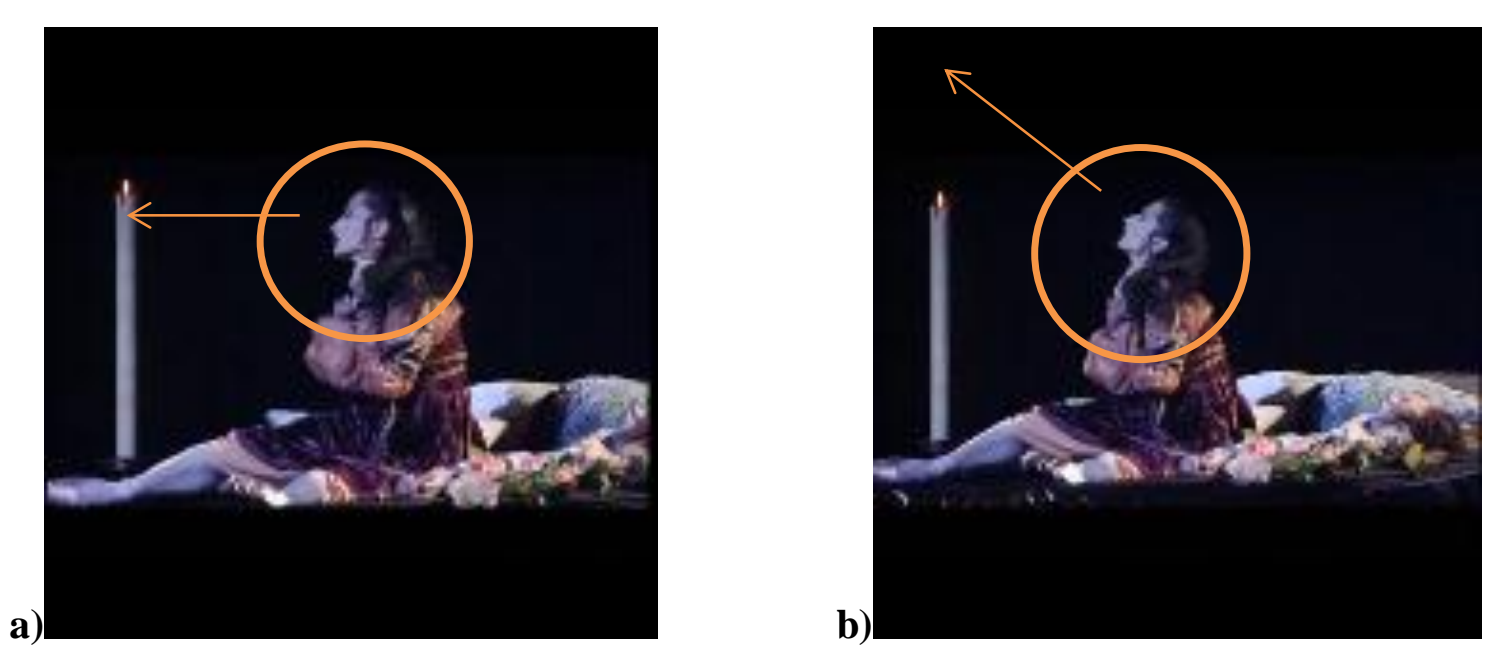

Figura 62. Gestos dêiticos na cena final, versão francesa. a) cabeça e olhar voltados para a lateral esquerda; b) cabeça e olhar voltados para diagonal alta.

Em (c), os ombros se voltam para a frente do palco, com o corpo inclinado para frente. A cabeça continua inclinada para trás e o olhar voltado para cima, mas agora direcionado para a diagonal alta frente. As mãos encontram-se apoiadas sobre a superfície da tumba, e as pernas mantêm a posição flexionada. Em (d), o olhar se volta para a diagonal alta, de perfil para o público, e a cabeça mantém a inclinação para trás. Os ombros estão de frente para a plateia, as mãos apoiadas no lado direito do corpo e as pernas voltadas para frente, em posição para a descida da tumba. 

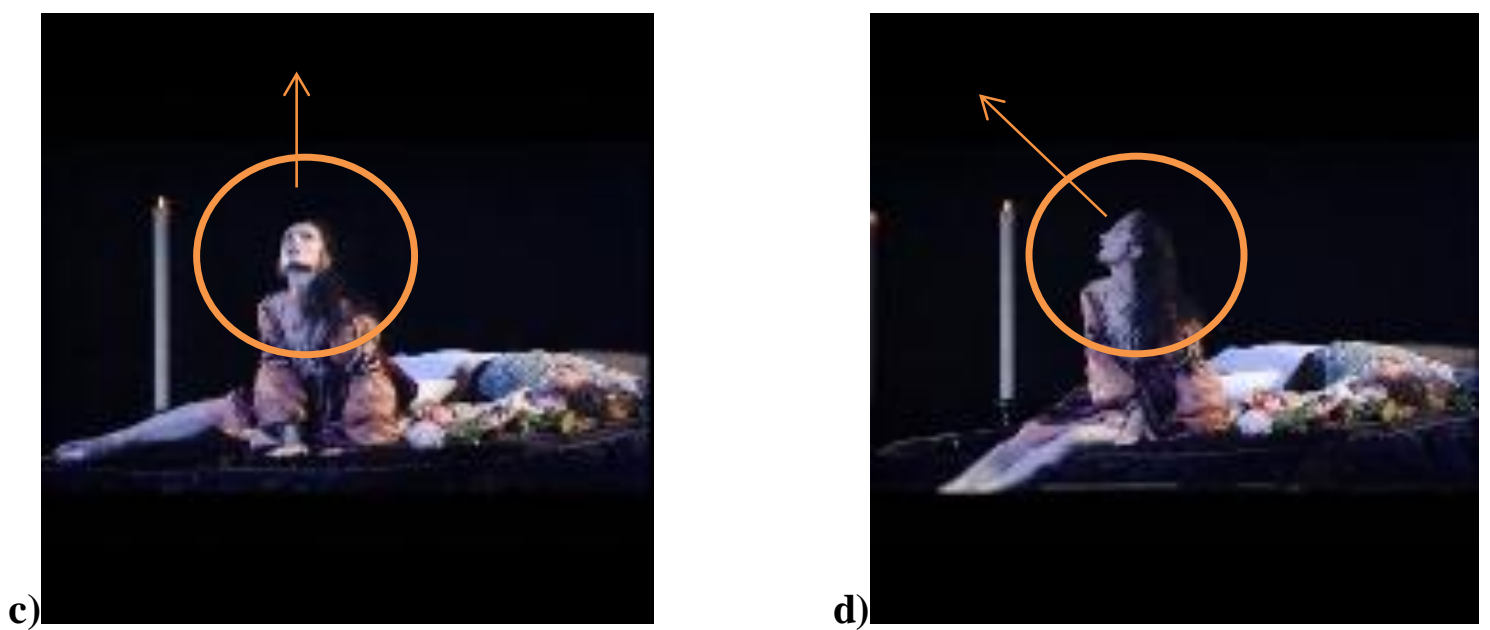

Figura 62. (cont.) Gestos dêiticos na cena final, versão francesa. c) cabeça e olhar para o alto e para frente; d) cabeça e olhar para o alto e para a lateral.

..1.....IVideos\Gestos Dissertação\Dêitico cf.wmv

No estabelecimento do entorno, a versão francesa usa preferencialmente o olhar direcionado para o alto e para a esquerda, sempre ocupando a parte frontal do espaço. Esse recurso parece ser utilizado para evitar o encontro do corpo de Romeu, que está sobre a tumba, ocupando sua parte posterior, já que ele só é encontrado em momento posterior da trama. Assim, parece haver uma oposição de direção de olhar para preservar a narrativa. Na versão inglesa, a bailarina tem mais liberdade para usar o olhar para baixo, não tendo o mesmo tipo de restrição da versão francesa, pois o corpo de Romeu está no chão, do lado esquerdo da tumba, fora de seu campo de visão. Não há necessidade de fazer nenhum tipo de oposição para evitar o encontro do corpo antes do momento propício. A diferença no modo de conceitualização da narrativa dessa parte da cena nas duas versões se encontra refletida nos gestos dêiticos escolhidos para o reconhecimento do entorno.

O encontro do corpo de Romeu é outro momento que envolve a produção de gestos dêiticos para indicar o referente. $\mathrm{Na}$ versão inglesa, isso acontece como uma casualidade em meio ao reconhecimento do entorno, após a descida da tumba, e se realiza através do olhar de Julieta. Nesse caso, a jovem esbarra o pé no corpo do amante (a). Em seguida, ela vira a cabeça e baixa os olhos e a cabeça para apresentar Romeu para a plateia, com o corpo de frente para o público e os braços buscando o reequilíbrio do corpo (b). 

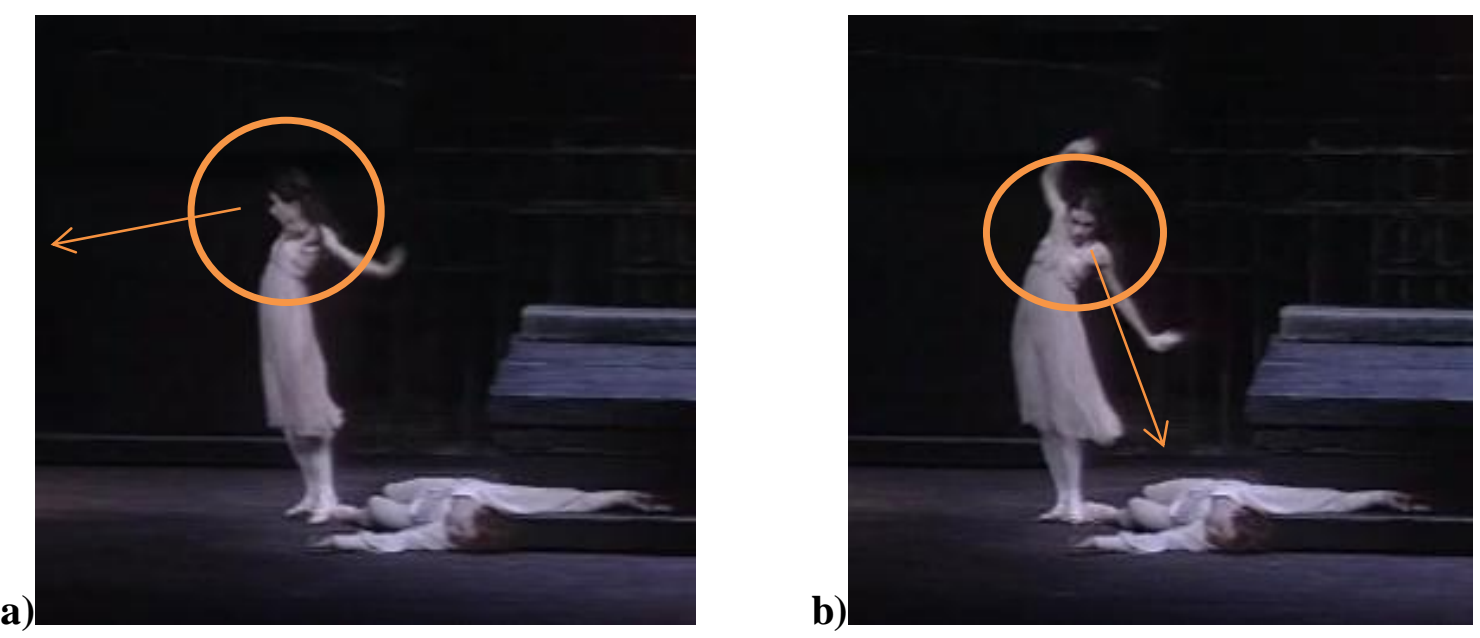

Figura 63. Gesto dêitico no encontro do corpo de Romeu, na versão inglesa. a) cabeça e olhar voltados para a lateral esquerda; b) cabeça e olhar voltados para a diagonal frente baixa.

..1.....|Videos \Gestos Dissertação|Dêitico 7.wmv

$\mathrm{Na}$ versão francesa, o encontro do corpo de Romeu acontece logo após o encontro do corpo de Paris. Julieta, ao afastar-se de Paris (a) e desviar o olhar de seu corpo (b), vira-se em direção à tumba da qual saíra para reconhecer o entorno (c).

a)

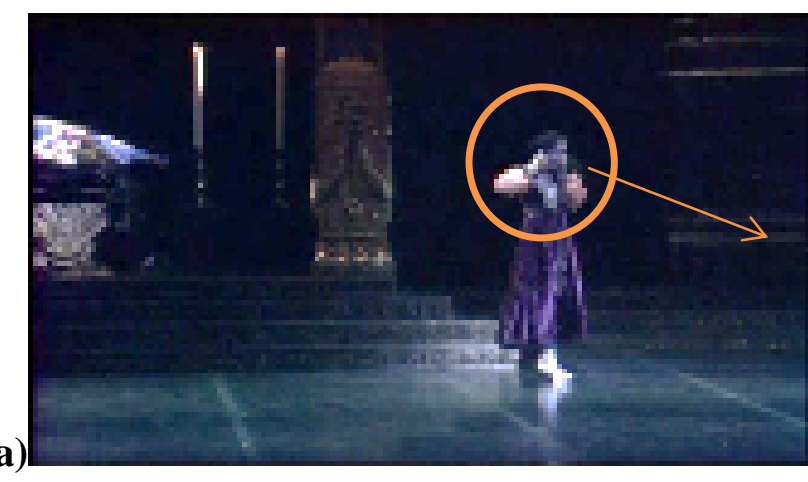

b)

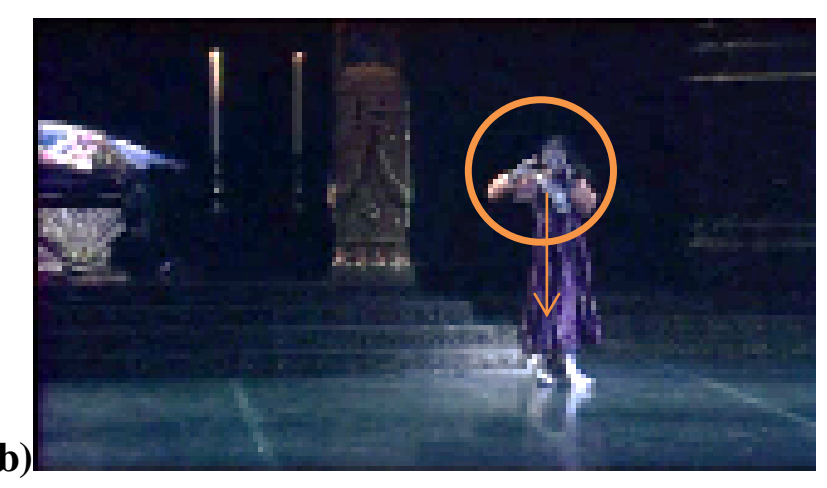




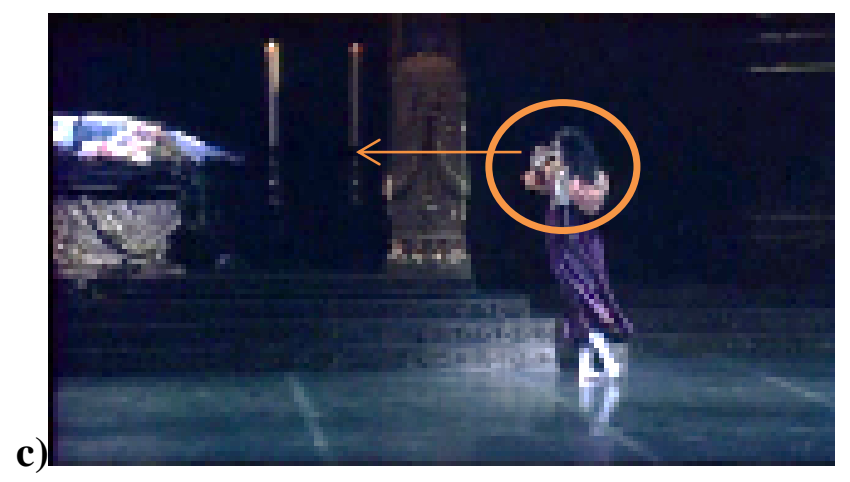

Figura 64. Gesto dêitico no encontro do corpo de Romeu, na versão francesa. a) cabeça e olhar voltados para a diagonal direita; b) cabeça e olhar voltados para baixo; c) cabeça e olhar voltados para diagonal fundo esquerda.

Ao virar-se para a diagonal esquerda, Julieta percebe, ao longe, o corpo de Romeu deitado sobre a tumba (d). A direção de sua cabeça é mantida, enquanto o corpo se desvira para chegar à mesma direção. Os braços, flexionados à altura dos ombros no início do movimento, estendem-se nessa mesma altura para manutenção do equilíbrio do corpo.

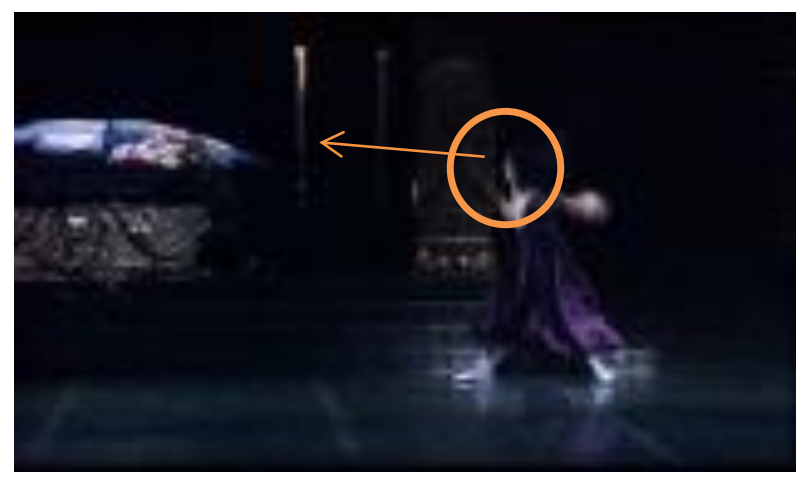

Figura 64. (cont.) Gesto dêitico no encontro do corpo de Romeu, na versão francesa. d) corpo se volta para acompanhar a direção da cabeça e do olhar. ..1... 1.. |Videos \Gestos Dissertação|Dêitico 8.wmv

A posição de cabeça das intérpretes revela a diferença na conceitualização da cena. MacMillan posiciona Julieta aos pés de Romeu, de modo que sua cabeça e seu olhar baixam para encontrar o corpo de Romeu. Já Nureyev posiciona Julieta longe de Romeu e, consequentemente, opta por fazê-la encontrar o corpo realizando um movimento de cabeça e corpo que traduz essa distância. O corpo do bailarino está sobre a tumba. Por isso, a cabeça e o olhar da bailarina mantêm uma linha diagonal para apresentar Romeu à plateia. Ao idealizar o gesto percorrendo um caminho que vai da diagonal anterior, passando pela frente do palco até a diagonal posterior, o coreógrafo permite ao público assumir a perspectiva da intérprete feminina, acompanhando o encontro do corpo do bailarino. 
Dos oito exemplos descritos, um exemplo tem uma sobreposição de signos, três apresentam conjugação de um gesto dêitico com outro tipo de gesto e dois apresentam conjugação com o nível técnico. No segundo exemplo apresentado (cf. figura 57), ocorre a sobreposição do gesto dêitico realizado com a cabeça e o braço por Romeu (o apontamento), de uma possível extensão diagramática (relação entre a escada e sua função) e de uma possível extensão metafórica (imagem para um convite ou pedido). Brandt (2005) propõe uma cascata de signos, na qual a percepção de um signo icônico é sucedida pela inserção desse signo como instância de uma categoria mais geral. Essa inserção corresponde a uma relação metonímica de parte pelo todo que, segundo Brandt, transforma uma ideia significante em símbolo (pg.4). Ele exemplifica o processo através da simbolização de uma placa de permissão de estacionamento com a letra E grafada. De ícone (a letra E pela palavra estacionar), a placa passa a ter uma interpretação de símbolo de permissão de estacionamento, em geral, para então funcionar como índice, apontando para o local onde o estacionamento é permitido. No caso da sobreposição observada no exemplo do gesto dêitico, parece acontecer um caminho semelhante em direção à simbolização, partindo, no entanto, de um índice (o braço apontando para a escada), que possibilita uma relação metonímica entre a escada e sua função (permitir a subida ou descida de pessoas) e uma posterior extensão metafórica (um convite para que Julieta desça as escadas).

No terceiro exemplo (cf. figura 58), o gesto dêitico realizado por Julieta com a cabeça e o olhar encontra-se conjugado a um gesto icônico metafórico realizado com os braços. Além da conjugação, ocorre, ainda simultaneidade de fases dos dois gestos. Já na conjugação do gesto dêitico descrito no quarto exemplo (cf. figura 59) não ocorre essa simultaneidade de fases. O golpe do gesto dêitico realizado com a cabeça por Romeu é anterior ao golpe do gesto icônico diagramático realizado com o braço. Nesse exemplo acontece a conjugação dos dois gestos com o nível técnico, assim como no exemplo seguinte (cf. figura 60), em que o gesto dêitico realizado com a cabeça e o olhar se associa a um passo técnico.

Apenas um gesto dêitico é realizado com o braço, mas ainda assim, ele é precedido de um gesto feito com a cabeça e o olhar. Aparentemente, a falta do signo linguístico para definir o espaço leva o olhar a conduzir o processo de estabelecimento da posição do referente. Como não é possível ler o olhar à distância, a cabeça acompanha o movimento dos olhos, seguida pelo tronco. A exceção acontece quando o 
braço é utilizado para enfatizar o movimento de cabeça, no segundo exemplo discutido acima. Nesse caso, o torso não segue o movimento da cabeça, mantendo a mesma posição do início ao fim do gesto dêitico. Nesse caso, a ênfase do gesto dêitico, talvez esteja ligada a um processo no qual a manifestação de uma ação faz uso de estratégias de estilização, exagero ou movimentos claramente perceptíveis ao interlocutor, para indicar mais enfaticamente a intenção na interação (Clark 1996, pp. 167-8).

Em todos os casos de produção de gesto dêitico com movimentos técnicos, o gesto foi feito com a cabeça e o olhar, não necessariamente nessa ordem, mas sempre antes do movimento do corpo. O mesmo ocorre nas cenas em que Julieta encontra o corpo de Romeu. Na versão inglesa, a cabeça e o olhar se voltam para Romeu antes do corpo. No caso da versão francesa, essa antecipação fica mais evidente com a torção do corpo ainda mais pronunciada. A tendência é a cabeça indicar a direção para a qual o corpo deve virar. A exceção, como já mencionado, é o gesto dêitico produzido com a cabeça e o braço, pois, nesse caso, o corpo não acompanha a direção da cabeça e do olhar. É o braço, e não o corpo, que acompanha a direção do apontamento feito com o olhar e a cabeça.

\subsection{Icônicos imagéticos}

O reconhecimento dos gestos dessa categoria se dá por identificação de similaridade total, direta e simples de qualidades do signo (Petrilli 2010, p. 264). Ou seja, não há necessidade de inferências ou paralelismos para que o signo seja interpretado. Retomando o contínuo apresentado na Introdução, os gestos icônicos imagéticos são aqueles que representam qualidades de apreensão direta, sem necessidade de mediação para sua interpretação. No exemplo de Farias e Queiróz (2006), o pictograma de homem só se torna possível pela identificação de similaridade com a silhueta de um ser humano do gênero masculino. No caso de gestos, os gestos icônicos imagéticos representam qualidades e características que estão mais próximas daquelas do protótipo da categoria na qual o objeto se insere. Por exemplo, um retângulo desenhado no ar para se referir a uma moldura reproduz a qualidade da forma da moldura a que o gesto se refere de forma direta, sem que haja necessidade de inferência ou paralelismo para seu entendimento.

Os gestos associados às pantomimas, consideradas ações construídas na literatura sobre línguas sinalizadas (Liddell \& Metzger 1998, Quinto-Pozos 2007, entre 
outros), possibilitam a análise em termos de uma proximidade ou um afastamento em relação ao protótipo da ação representada, a partir dos signos gestuais presentes na representação. Assim, um beijo poderá ser conceitualizado e representado de diferentes modos ao longo da coreografia. A estratégia da pantomima aproxima a ação da memória motora do público, pelo reconhecimento de estratégias de interação do corpo no mundo, reproduzindo qualidades dos gestos envolvidos na ação.

Exemplos de gestos icônicos imagéticos foram retirados de um excerto de pantomima, no início da cena do balcão. Julieta está na sacada, sorrindo e lembrando dos acontecimentos do baile. O entendimento de que ela está se lembrando do baile vem através de uma sequência de gestos icônicos metafóricos, icônicos diagramáticos e dêiticos. De repente, ela ouve um barulho e dá um passo para trás, escondendo-se atrás da pilastra, com uma expressão que é um misto de ansiedade e curiosidade. Em seguida, ela se debruça sobre o parapeito, na tentativa de ver o que está provocando o som. A postura do corpo e da cabeça, projetadas para frente, com as mãos apoiadas para favorecer o equilíbrio do corpo são elementos que contribuem para a reprodução da ação de alguém que procura algo que está numa posição inferior. Essa é uma imagem bastante próxima do modelo que temos de procura de algo que está abaixo de nós, por isso a classificação do gesto nesta categoria.

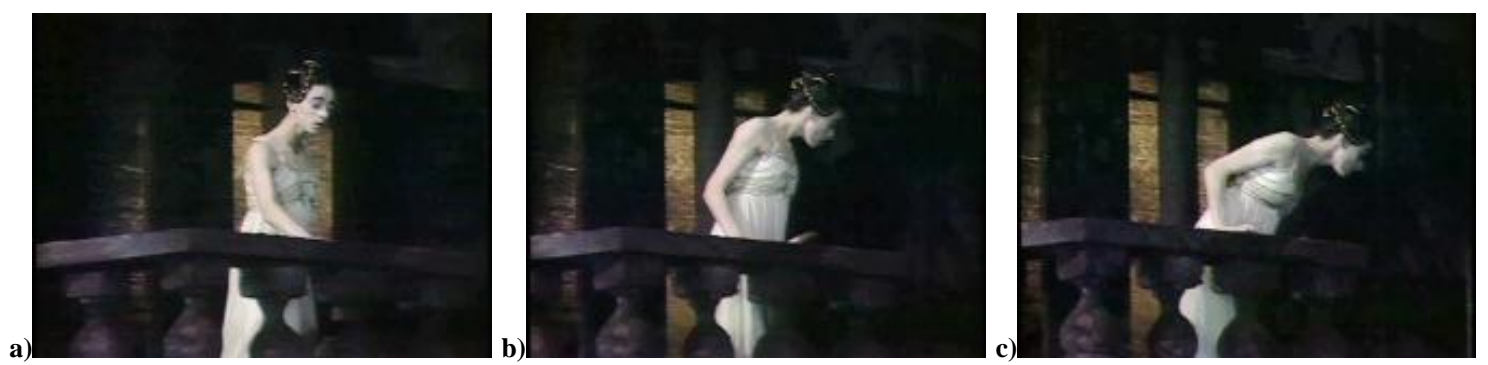

Figura 65. Exemplo de gesto icônico imagético na cena do balcão. a) ponto inicial do gesto; b) ponto medial; c) ponto final, com projeção do tronco e da cabeça para frente.

........ Videos\Gestos Dissertação\Imagético 1.wmv

Outro exemplo são os gestos utilizados no beijo dado por Romeu em Julieta, mais adiante na mesma cena. Na primeira ocorrência, Romeu parte de um gesto icônico metafórico - produzido com a mão e o braço direito estendidos em relação a Julieta, num possível oferecimento de algo a ela - e produz um gesto icônico imagético girando o corpo pela esquerda, que é um percurso exterior à sua posição em relação à Julieta, levantando o braço esquerdo no percurso. Ao terminar o giro, ele leva o braço para fora, com o cotovelo flexionado para cima e mantendo o corpo voltado para a diagonal 
frente. Ao inclinar o corpo para a esquerda, ele termina a elevação do braço e coloca sua mão na face esquerda de Julieta, unido a ela pelos ombros. A cabeça também mantém a diagonal do corpo durante o beijo. É possível propor que essa posição final esteja de acordo com um decoro correspondente à relação estabelecida entre os dois até aquele momento. Julieta abraça o braço de Romeu que cruza seu peito, ao mesmo tempo em que coloca sua mão sobre a mão de Romeu que está em sua face esquerda, através de gestos icônicos diagramáticos, analisados mais adiante. Os bailarinos estão na parte central do palco, mais próximos do fundo do que da frente.
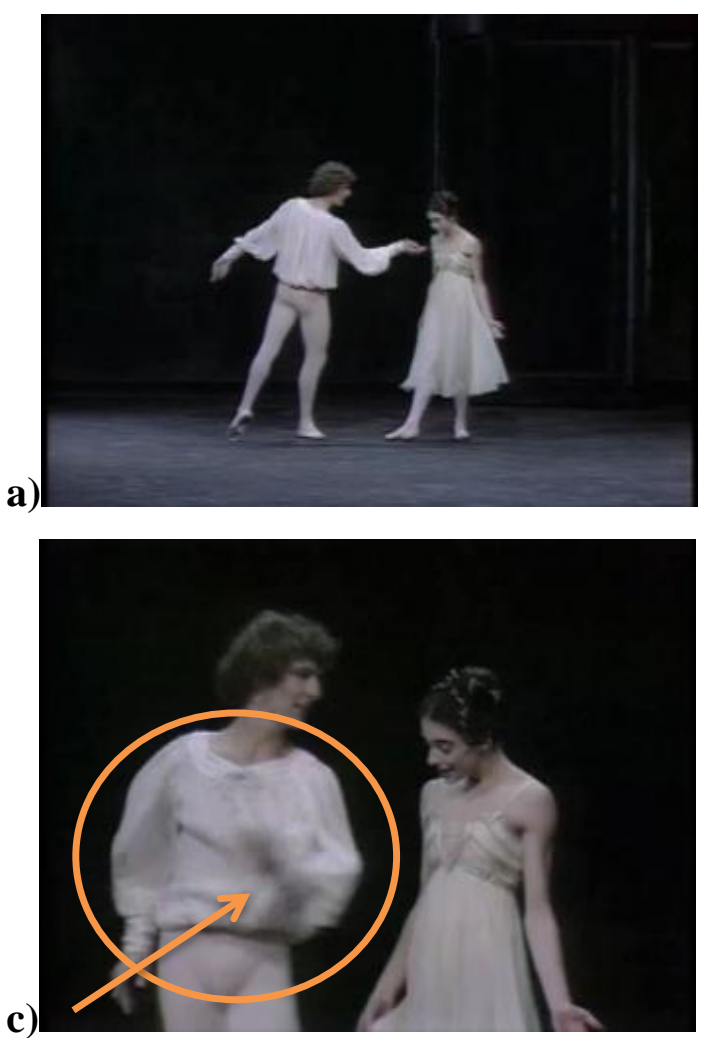

b)

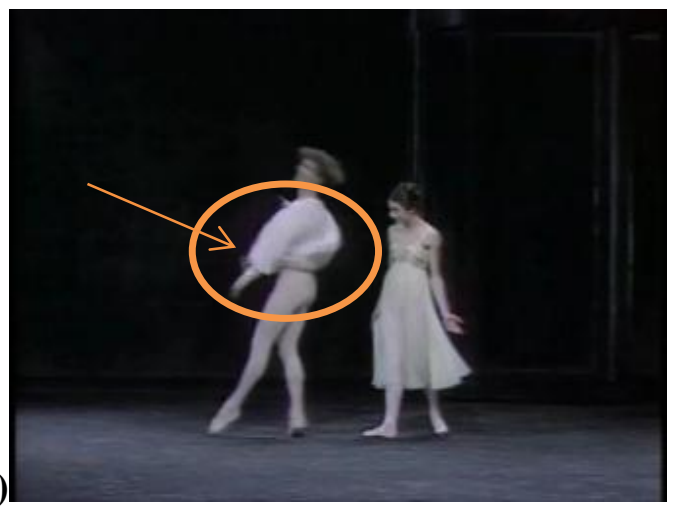

d)

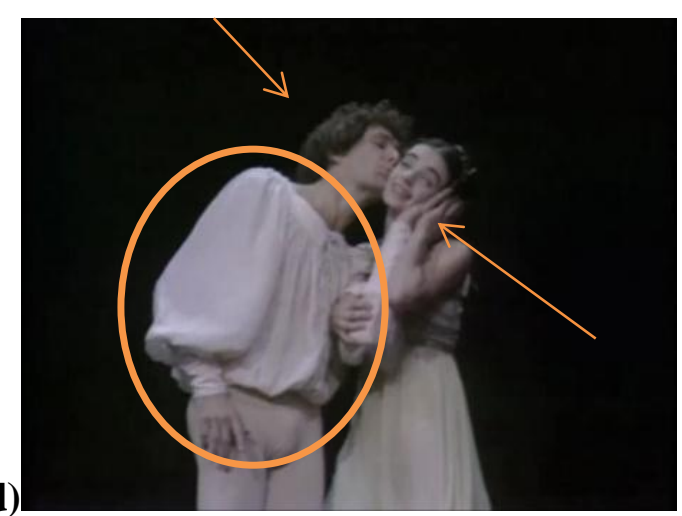

Figura 66. Exemplo de gestos icônicos imagéticos retirados da cena do balcão na versão inglesa. a) posição do gesto anterior; b) início do movimento de rotação do corpo; c) final do movimento com o corpo, com movimento de braço; d) posição final.

..1.....Videos \Gestos Dissertação\Icônico imagético 2a.wmv

Se observarmos outra ocorrência de beijo, em momento posterior da cena, é possível ver que a configuração dos articuladores se modifica, criando diferentes signos para a mesma ação. Nessa segunda ocorrência, ao final da cena do balcão, o beijo é uma imagem de um beijo mais íntimo, devido aos gestos icônicos imagéticos realizados pelos braços e pelo corpo escolhidos para a pantomima. O casal está na parte anterior esquerda do palco, mais próximo da coxia. Romeu inicia a pantomima com o corpo voltado para Julieta e as mãos em sua cintura. Ele ergue o braço direito por trás do corpo dela, flexionando o cotovelo para cima, até a mão chegar à parte posterior da 
cabeça da bailarina para apoiá-la, aproximando seu corpo do dela. A aproximação do corpo se reflete na aproximação das cabeças e, consequentemente, seus lábios dos dela. Em fase distinta, o cotovelo esquerdo, que já se encontrava flexionado para cima, elevase da lateral para frente do corpo. Ao realizar esse movimento com o braço, o bailarino desliza sua mão esquerda pela cintura da bailarina até encostar o antebraço em seu corpo. A partir desse momento, Romeu encosta seus lábios nos de Julieta e inicia o gesto do torso, inclinando-o para a direita e depois para frente, em um percurso que vai da esquerda para a direita, mantendo a postura de braços e cabeça. Simultaneamente, Julieta realiza um gesto icônico metafórico com os braços.

a)

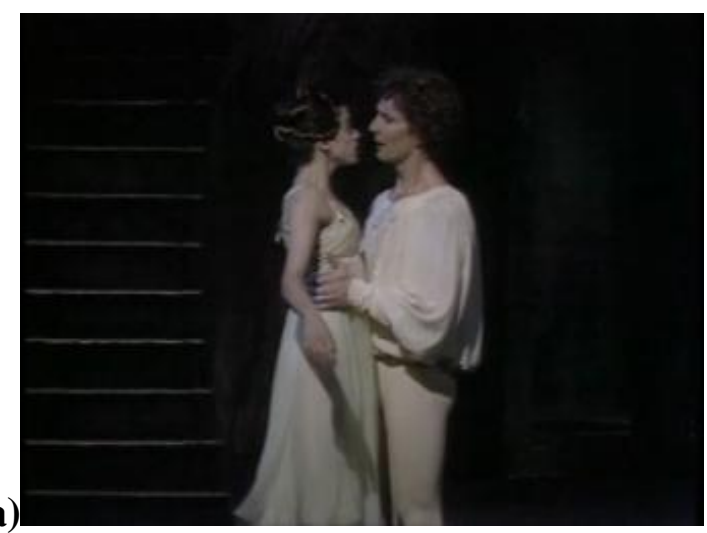

c)
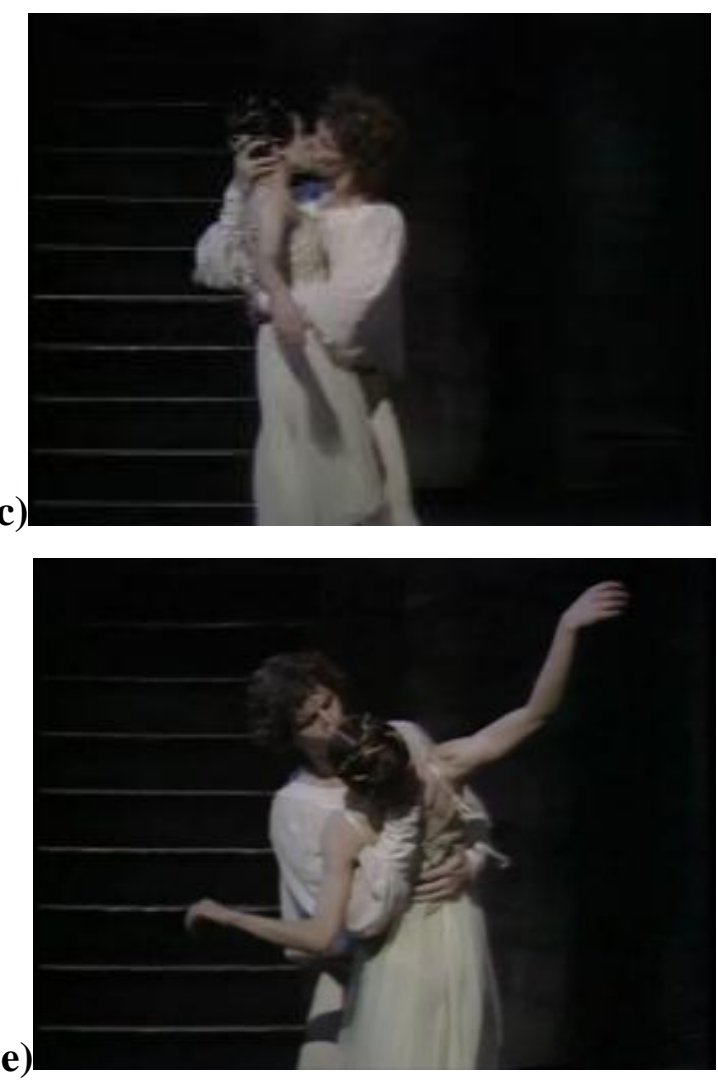

b)

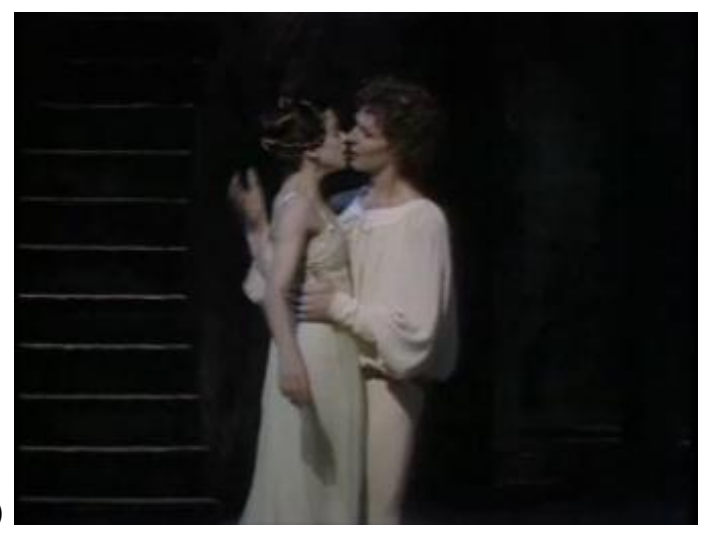

d)
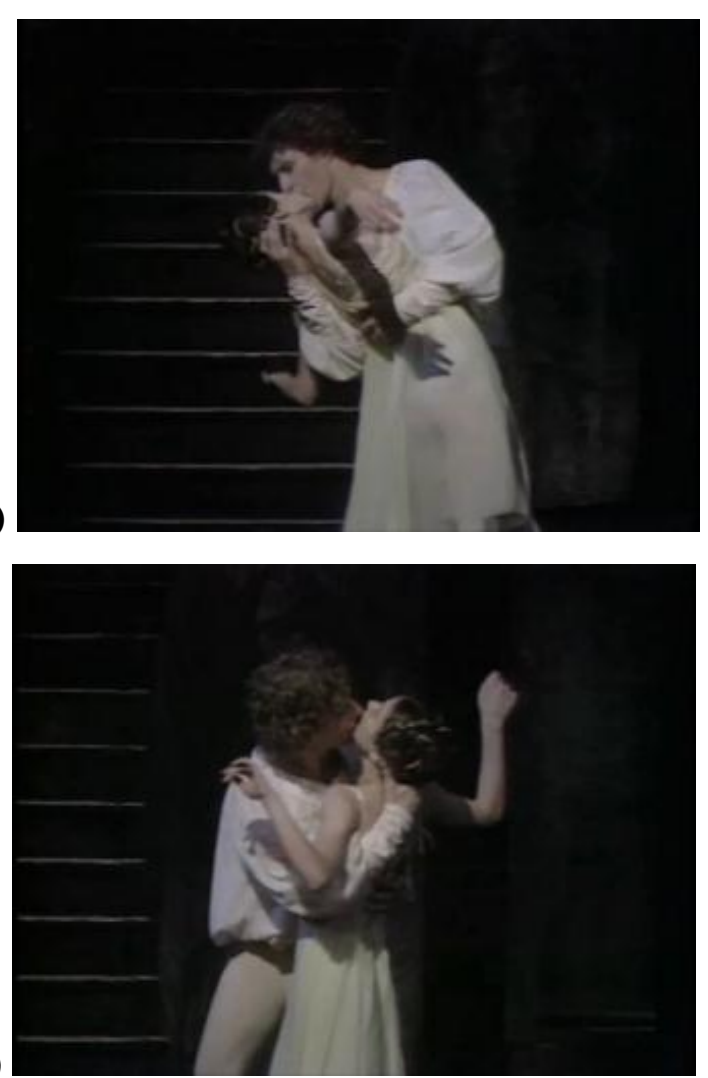
Figura 67. Exemplos de gestos icônicos imagéticos retirados da cena do balcão. a) posição inicial; b) início do gesto de braços; c) posição final do gesto de braços; d)início do gesto corporal; e) posição intermediária do corpo; f) posição final do corpo.

........Videos\Gestos Dissertação|Icônico imagético 2b.wmv

A descrição das duas pantomimas mostra um aumento no grau de intimidade estabelecido pelo coreógrafo para as personagens, obedecendo a uma ordem cronológica. Assim, o primeiro exemplo está mais aproximado de um beijo menos íntimo, devido à posição dos corpos dos bailarinos, assim como à posição do rosto de Romeu. O local onde seus lábios encostam em Julieta também é indicador de menor grau de intimidade entre os participantes da ação. $\mathrm{O}$ oposto acontece com o segundo exemplo, aproximando o beijo do protótipo de beijo apaixonado. Nesse exemplo, os corpos dos bailarinos estão frente a frente, colados, os braços de Romeu enlaçando o corpo de Julieta e os lábios de Romeu estão sobre os lábios de Julieta. Ainda que a ação seja a mesma, aproximar os lábios em posição protusa do corpo de outra pessoa, a composição de gestos com articuladores em diferentes configurações constrói pantomimas com diferentes qualidades. Essa distinção não seria possível no sistema de categorização proposto por Humphrey (1957), pois ambas as ocorrências seriam classificadas como gestos sociais, sem que as diferentes qualidades dos gestos pudessem ser alcançadas.

O próximo exemplo traz o movimento realizado com o braço direito em meio a uma corrida (figura 68). Julieta se declara a Romeu por meio de um gesto icônico metafórico - no qual ela coloca as duas mãos espalmadas sobre o lado esquerdo superior do torso, toma a mão direita de Romeu na sua e a leva de encontro à outra que fícou sobre o peito - e corre para longe dele. Romeu a segue para impedi-la de fugir, produzindo um gesto icônico imagético, correspondente ao movimento realizado para impedir um corpo de prosseguir em seu percurso. Julieta sai do centro do palco e corre em direção à diagonal fundo, e Romeu a segue para se colocar no caminho dela e impedir que ela prossiga em fuga. O movimento do braço de Romeu é executado com o cotovelo partindo de uma posição muito flexionada na frente do corpo (a) até uma posição completamente estendida quando inicia o caminho para a lateral, o punho levemente fletido no sentido do dorso da mão a partir do momento de extensão do cotovelo, os dedos relaxados e a palma da mão voltada para baixo (b). O braço se estende à altura dos ombros de Julieta, de modo que ela não possa continuar a corrida na direção anterior. 
a)

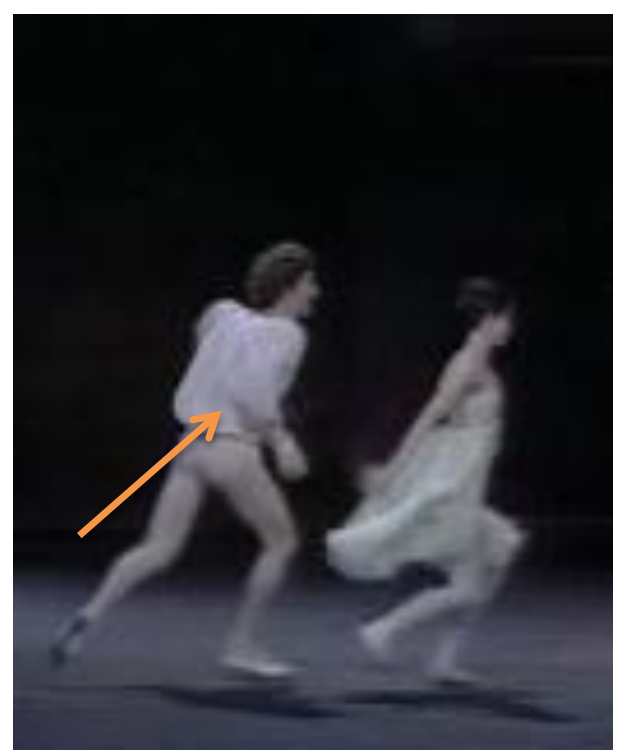

b)

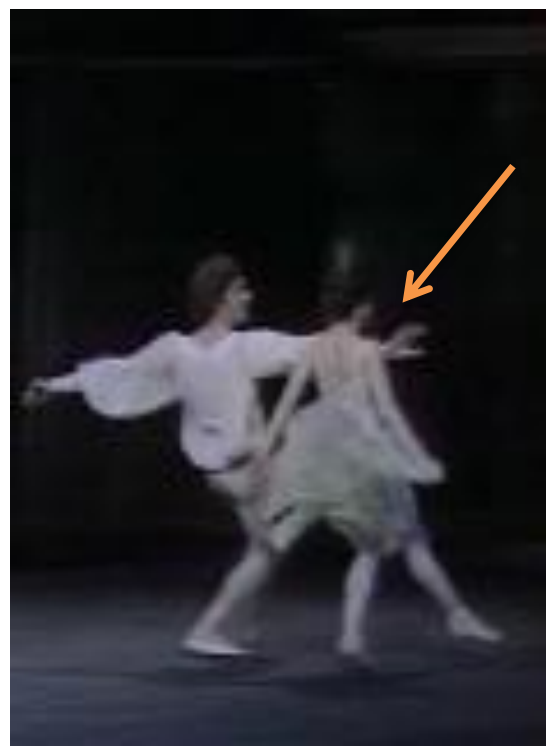

Figura 68. Exemplo de gesto icônico imagético retirado da cena do balcão. a) posição inicial com flexão do cotovelo para trás; b) posição final do braço e da mão direita.

..1..... Videos/Gestos Dissertação|Icônico imagético 4.wmv

Nenhuma das configurações de braço descritas corresponde às posturas presentes na técnica: quando o braço se levanta à frente do corpo, o cotovelo deve estar arredondado e voltado em direção ao centro do corpo, conforme a postura da primeira posição (cf. figura 8), com o punho e dedos relaxados e a palma da mão voltada para o centro do corpo, acompanhando a direção do cotovelo; na segunda posição (cf. figura 9) a postura do cotovelo se mantém, assim como a do punho, dedos e palma da mão, não mais à frente do corpo, mas na sua lateral. A partir da diferença entre as posturas técnicas e aquelas do bailarino, observadas na figura 64, considero o movimento de braço como um gesto. E, dada sua forma e o contexto no qual esse gesto acontece, proponho sua classificação como icônico imagético. Talvez seja possível considerá-lo uma estilização, no sentido da proposta de Hanna (1990), na medida em que reproduz um gesto convencional ${ }^{66}$. Esse também é um exemplo de movimento de outras partes do corpo que não as mãos que se torna visível e contribui para a construção de significado.

Observei outros exemplos de gestos icônicos imagéticos na cena que acontece do lado de fora da casa da família Capuleto, logo antes do grande baile. Essa cena retrata a chegada dos convidados para o baile, chamados a entrar no palácio pelo patriarca Capuleto através de um gesto que reproduz a ação de chamar alguém. Romeu

66 Os dispositivos simbólicos propostos por Hanna (1990) para a interpretação da dança foram mencionados nas páginas 34-35 acima. 
e seus dois amigos ainda dançam antes de seguir o grupo para o salão. Nessa dança, executam diversas sequências de saltos, piruetas, arabesques e rond de jambe en l'air. $\mathrm{O}$ rond de jambe en l'air é um movimento circular realizado com a parte inferior da perna, a partir do passé (cf. figura 16), com rotação executada pela frente da perna elevada (en dehors) ou por trás dela (en dedans). Ele pode ser realizado com o auxílio da barra, durante uma aula, ou no centro, sem auxílio de barra, tanto em aula como em cena, como ilustrado abaixo.

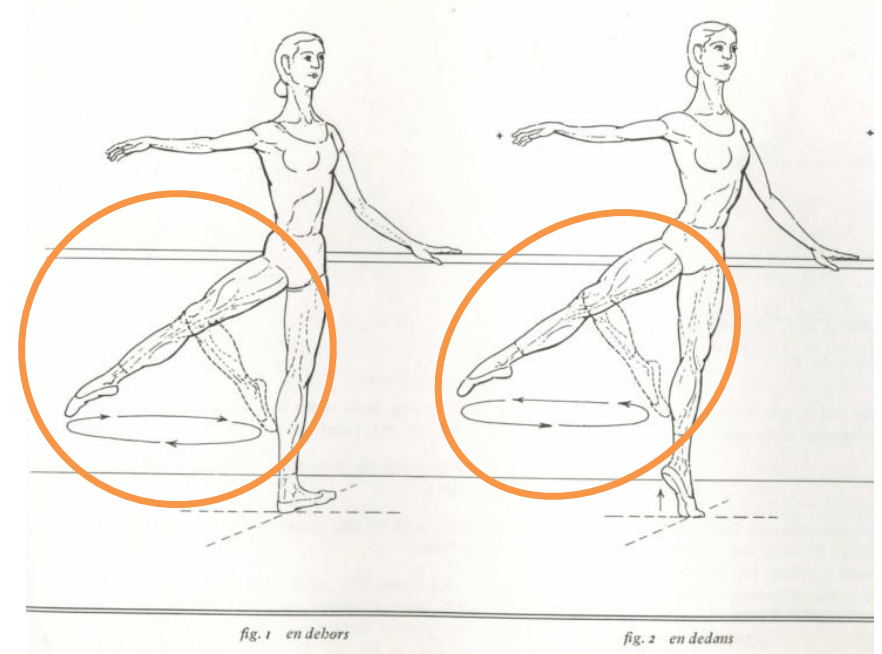

Figura 69. Rond de jambe en l'air na barra, retirada de Kirstein, Stuart e Dyer (1952, p. 69). 


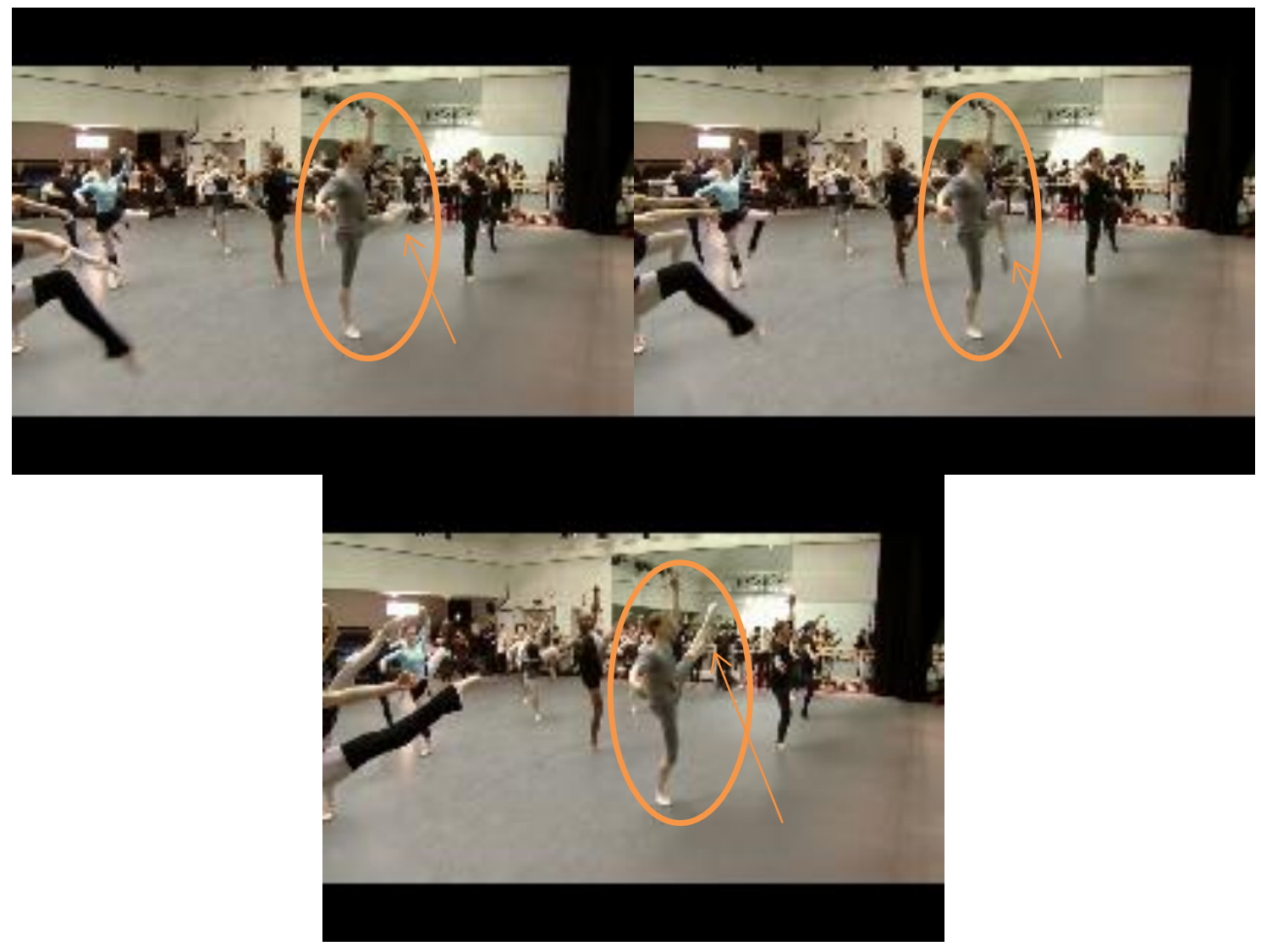

Figura 70.Rond de jambe en l'air no centro ${ }^{67}$.

....... Videos $\backslash$ Gestos Dissertação\Rond de jambe aula.wmv

Em uma das diversas sequências realizadas antes da entrada no salão de baile

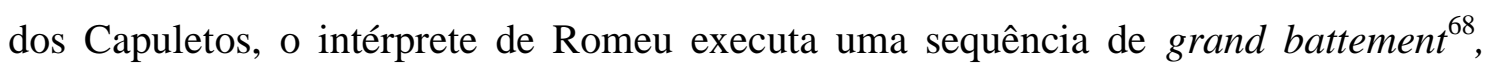
rond de jambe en l'air, enveloppé $e^{69}$, grand battement com a perna direita, ao mesmo tempo em que os braços executam, duas vezes, movimentos de esgrima (a), sem o florete ou o sabre. Esses movimentos de braço são repetidos mais duas vezes ainda, na sequência, durante a execução de arabesques ouvertes (cf. figura 9) (b).

\footnotetext{
${ }^{67} \mathrm{O}$ exemplo de sala de aula foi retirado do vídeo Royal Ballet Daily Class, disponibilizado no endereço http://www.youtube.com/watch?v=5EVMjnHFg-w.

${ }^{68} \mathrm{O}$ grand battement é a elevação rápida de uma perna e pé estendidos à frente, ao lado ou atrás do corpo. ${ }^{69} \mathrm{O}$ enveloppé é um passo que tem o percurso oposto ao do developpé, descrito no capítulo 1, seção 1.2.1.2, pg.29. Ou seja, uma perna é elevada estendida à frente, ao lado ou atrás do corpo, até noventa graus, para, então, ser flexionada até a posição de passé (cf. figura 16) para depois voltar à quinta posição de pés (cf. figura 7).
} 

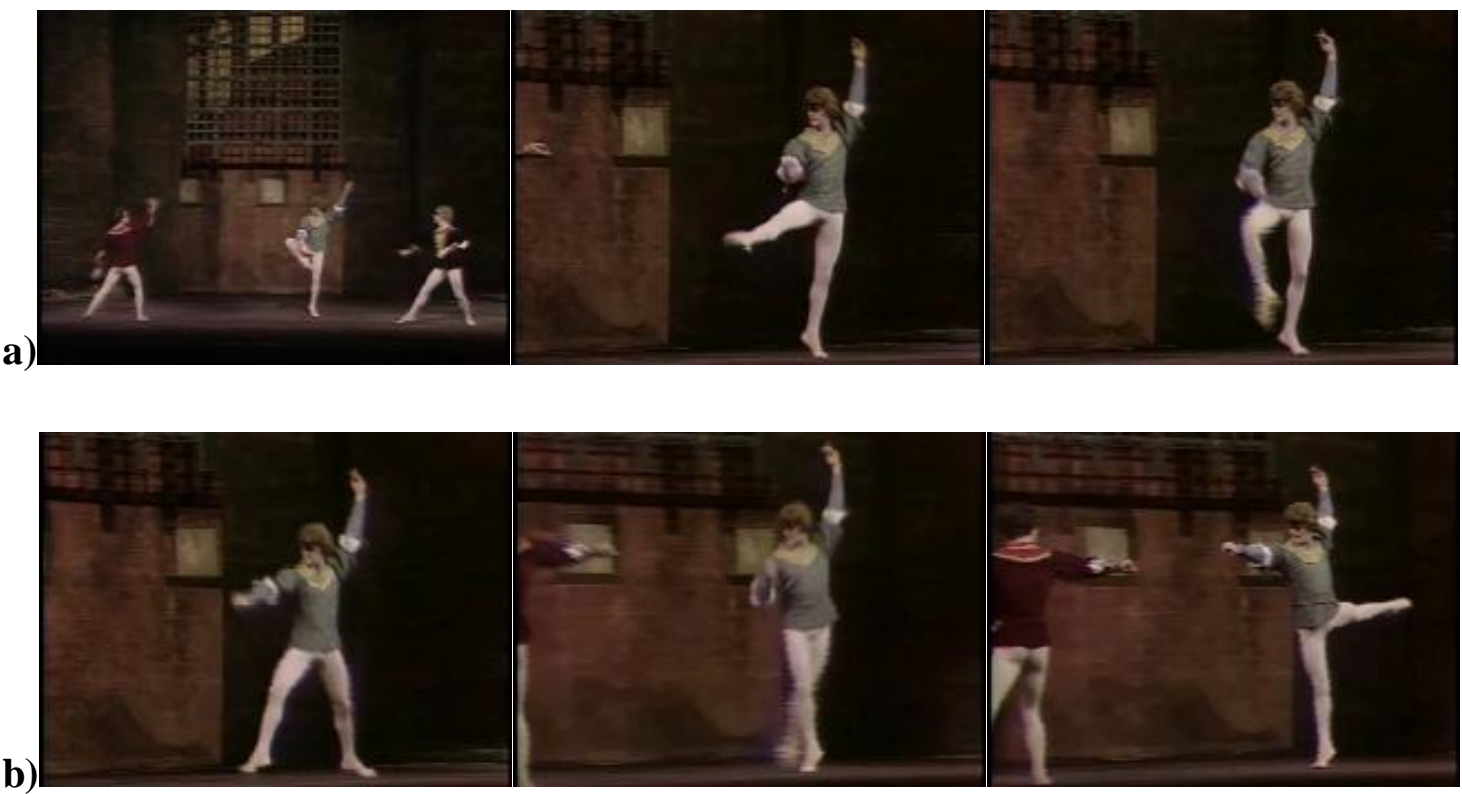

Figura 71. Exemplo de gesto icônico imagético. a) gesto conjugado com rond de jambe en l'air e enveloppé. b) gesto conjugado com arabesque.

..1.....|Videos\Gestos Dissertação|Icônico imagético 5.wmv

A posição do braço esquerdo na esgrima, elevada ao lado ou atrás da cabeça, é bastante semelhante a uma segunda ou quinta posições de braços na dança. Provavelmente a aproximação seja devida ao treinamento em dança indicado por Luis XIV aos cavaleiros, por ocasião do estabelecimento da Academia Real de Dança, na França, além de ser uma posição mais apropriada para a manutenção do equilíbrio do corpo.

Nesse exemplo, é possível perceber claramente como os níveis técnico e gestual estão distinguidos um do outro, atuando, no entanto, conjuntamente para a construção do signo visual. É um exemplo que dá subsídios para a estrutura tripartite do discurso dançado, proposta neste trabalho.

$\mathrm{Na}$ cena final, repleta de pantomima, há várias ocorrências de gestos icônicos imagéticos. Entre outras, destaco aquela que compõe o abraço dado por Julieta em Romeu, na versão francesa. Nessa versão, aparentemente por ter encontrado o corpo de Romeu à distância, Julieta não se dá conta da morte do amante (a). Ela o abraça, no primeiro momento sustentando as costas de Romeu com ambas as mãos. Depois, com um braço sustentando as costas e o outro a cabeça do bailarino, traz o rosto de Romeu próximo ao seu, refletindo em sua face e em sua posição corporal a alegria pelo reencontro com o amante (b). A face inclinada para cima, os olhos fechados e os lábios entreabertos em um sorriso, com o rosto de Romeu também inclinado para cima (c), 
contribuem para a composição do retrato de alegria de Julieta. A posição de perfil dos dois intérpretes minimiza o efeito dos braços pendidos de Romeu em um gesto metafórico, no qual os braços pendidos ao lado do corpo podem ser interpretados como uma representação de morte.

a)

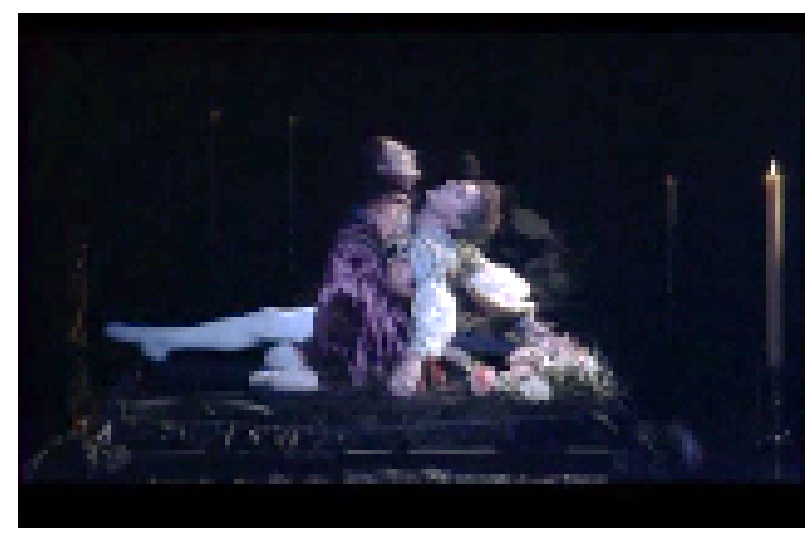

b)

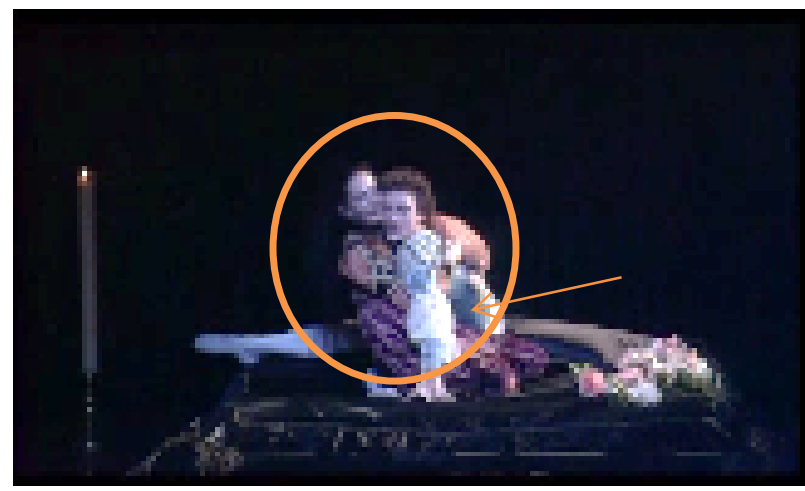

c)

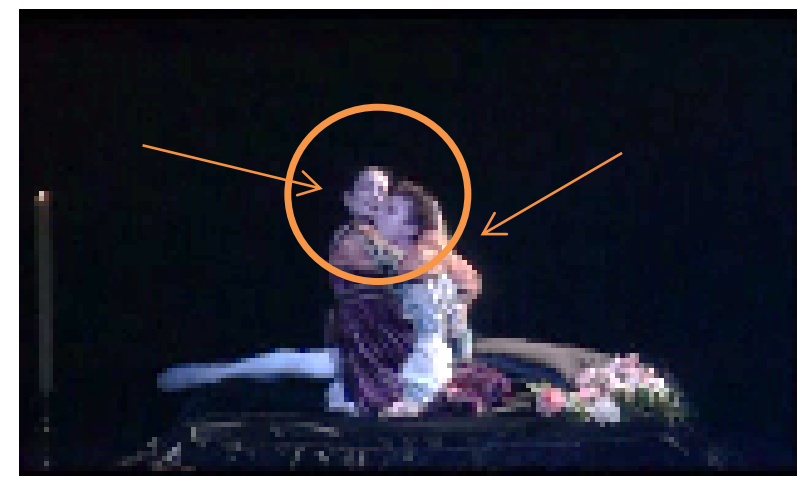

Figura 72. Abraço com gesto icônico imagético, retirado da cena final na versão francesa. a) posição inicial; b) suporte do corpo com as duas mãos nas costas; c) suporte do corpo com uma mão nas costas e a outra na cabeça. .........IVideos|Gestos DissertacãolAbraço Opera.wmv

Nesse exemplo também ocorre uma composição gestual, com os braços e o corpo compondo uma imagem e o rosto dando forma a um sentimento, em um gesto icônico metafórico, produzido pela configuração da boca, das pálpebras e das sobrancelhas, reproduzindo a alegria de Julieta pelo reencontro com Romeu. Essa composição mostra a questão posta por Mittelberg (2006), e anteriormente apresentada, 
de diferentes dimensões semióticas compondo o todo gestual. Nesse caso, a dimensão mais saliente parece ser a imagética em decorrência do ponto em que o gesto se situa dentro da sequência narrativa. O aspecto metafórico da felicidade pelo reencontro já havia sido explorado em um momento precedente e volta a ser explorado na sequência do gesto icônico imagético.

A categoria dos icônicos imagéticos não é tão frequentemente associada à técnica, mas parece bastante produtiva com relação à pantomima. Minha hipótese para essa diferença de correlação é o fato de a técnica estar menos associada à movimentação cotidiana. Ao usar uma movimentação mais abstrata, pode-se argumentar que o coreógrafo 'se aproveita' da abstração em curso para elaborar gestos que também necessitam de inferência e paralelismo, reservando os gestos mais concretos para movimentos cotidianos.

Na cena defronte ao castelo dos Capuletos, acontece uma coordenação entre a produção dos gestos e a produção dos movimentos técnicos. As pernas esticadas à frente ou atrás do corpo favorecem a extensão do cotovelo do braço que reproduz movimentos de espada. Os movimentos circulares de braço são executados durante o failli (que é feito com a flexão da perna da frente). E há um relaxamento do cotovelo do braço que está estendido à frente quando o bailarino executa o rond de jambe (que é produzido com flexão do joelho). É possível supor que essa relação entre o movimento das pernas e o do braço ajude a coordenação do movimento global. A produção de um movimento contraintuitivo - nesse caso, a execução simultânea de um movimento de extensão com as pernas e de um movimento de rotação com o braço - demanda mais atenção por parte do bailarino e exige maior tempo de treinamento para ser possível atingir um grau de fluidez de movimento semelhante àquele encontrado em movimentos intuitivos - como os mencionados acima, em que movimentos com flexão são realizados ao mesmo tempo por braços e pernas e movimentos com extensão de perna e braço são executados simultaneamente.

De maneira geral, parece que a categoria dos gestos icônicos imagéticos poderia ser aproximada do dispositivo simbólico da estilização, de acordo com a proposta de Hanna (1990), por sua proximidade com gestos convencionais de uso cotidiano. No entanto, eles também poderiam ser considerados como concretizações, ou movimentos que externalizam aspectos de algo, no sentido de apresentarem aspectos de ações. 
Aparentemente, a classificação de Hanna também não pode ser categórica, no sentido de que os dispositivos propostos compartilham traços de representação.

\subsection{Icônicos diagramáticos}

Gestos icônicos diagramáticos refletem um processo metonímico, pois salientam uma parte da estrutura que será interpretada pela estrutura como um todo. Diferentemente da apreensão da imagem, o diagrama pressupõe ou $(i)$ uma abstração para que a parte possa representar o todo, indo além da percepção imagética; ou (ii) uma abstração para que elementos do signo possam relacionar-se a elementos do objeto (Liska 1996, p. $37^{70}$ ). A abstração metonímica acontece a partir da percepção de um ícone.

No exemplo abaixo, retirado da cena do balcão, um gesto icônico diagramático produzido pelos dois bailarinos quase simultaneamente reproduz a tentativa de Romeu e Julieta de tocarem as mãos. Os braços estendidos, no caso de Romeu para cima, no de Julieta para baixo, com as mãos e dedos também estendidos e a cabeça acompanhando a direção apontada pelos braços, expressam elementos de um possível contato de mãos. O corpo de Julieta encontra-se flexionado para frente, sobre o parapeito, enquanto o de Romeu projeta-se para o alto e levemente para trás, para possibilitar a extensão do braço à frente da cabeça inclinada para trás, além de estar no relevé, que o projeta um pouco mais para cima. Tem-se uma representação estrutural de contato de mãos com todos os elementos necessários para isso presentes, sem que o contato de fato aconteça. Essa representação deve ser completada pelos interlocutores, através do processo de complementação de padrão, citado por Fauconnier e Turner (2002, p. 48). A complementação de padrão é um processo de conceitualização através do qual preenchemos as lacunas de uma cena com base em esquemas abstraídos de nossas experiências pregressas com relação àquele cenário. Por exemplo, somos capazes de completar uma linha situada atrás de um retângulo, ainda que ele se sobreponha à linha e não nos permita sua visualização completa. No caso do gesto produzido pelos bailarinos, é possível complementar a parte da ação que se refere ao toque das mãos,

\footnotetext{
${ }^{70}$ In Mittelberg, I. (2006). Metaphor and metonymy in language and gesture: Discourse evidence for multimodal models of grammar. Ithaca, NY: Cornell University. (p.120).
} 
propriamente, com base em nossas experiências com tentativas de tocar as mãos de outra pessoa.

a)

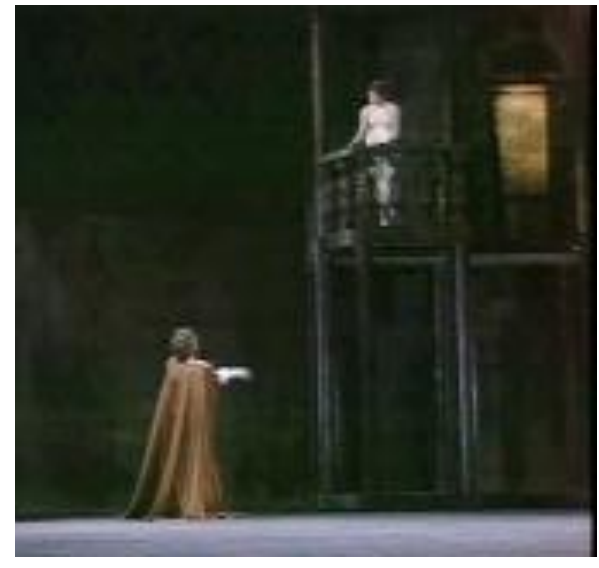

b)

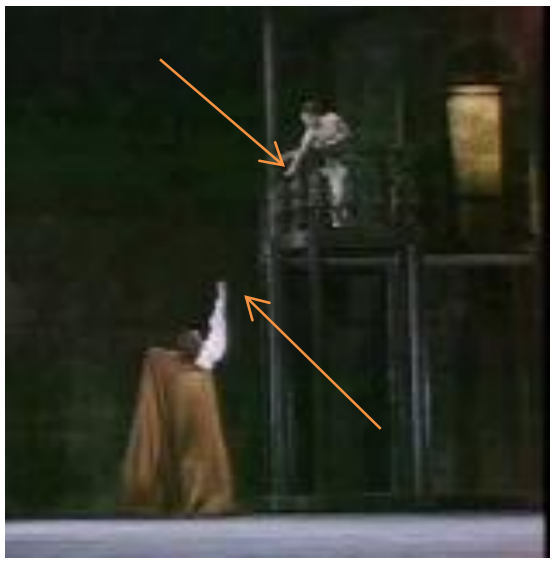

Figura 73. Exemplo de gesto icônico diagramático, produzido tanto por Romeu quanto por Julieta. a) preparação do gesto; b) posição final do gesto.

..1.....|Videos/Gestos Dissertação|Diagramático 1.wmv

Depois da declaração de Julieta, feita por meio de um gesto icônico metafórico com as duas mãos espalmadas sobre o lado esquerdo superior do torso -, Romeu dança a sua declaração a ela, realizando, durante a sequência coreográfica, vários gestos não estabelecidos na técnica clássica. Apresento, a seguir, um gesto icônico diagramático que ocorre simultaneamente com o nível técnico em dois momentos. O gesto é realizado após uma pirueta passé, terminando na quarta posição croisé allongé, isto é, com a perna direita na frente flexionada e a perna esquerda atrás esticada ${ }^{71}$. Dentro da técnica clássica, as piruetas terminadas em posições abertas de pés, como a quarta ou o arabesque, tendem a ser finalizadas com posições de braço abertas, como a segunda ou terceira posições ou braços de arabesque ${ }^{72}$. Abaixo, ilustro, com um exemplo retirado de uma aula da companhia do The Royal Ballet, a terminação canônica de pirueta passé com os braços em arabesque, realizada pela bailarina que se encontra na posição central, à frente, destacada pelo círculo laranja na figura 74, com cotovelos estendidos e palmas das mãos viradas para baixo.

\footnotetext{
${ }^{71}$ A posição allongé pode ser executada com ou sem o apoio do calcanhar da perna que está atrás.

${ }^{72}$ As piruetas terminadas em posições fechadas, como a quinta posição de pés, são finalizadas tanto com posições fechadas de braço como a primeira ou quinta posições, quanto com posições abertas, como a segunda, terceira ou quarta posições. No entanto, para essas piruetas, muito raramente é utilizada uma posição de arabesque.
} 


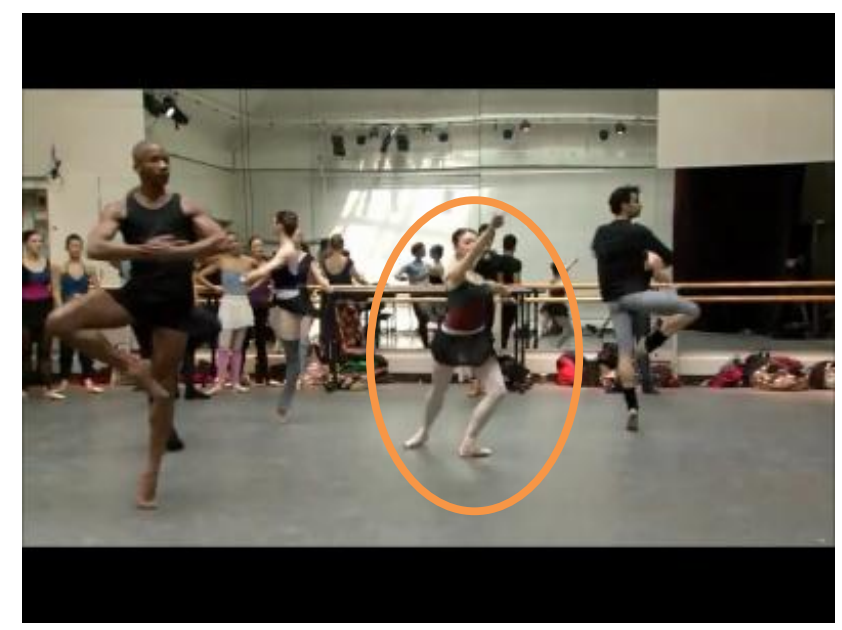

Figura 74. Exemplo de uso canônico dos braços ao final de uma pirueta passé $e^{73}$. ..1..... Videos $\backslash G$ estos Dissertação|Ex Pirouette in class a tempo.wmv

No exemplo retirado de Romeu e Julieta (figura 76), os braços do bailarino terminam a pirueta passé (a) em oposição às pernas (b). O braço esquerdo tem o cotovelo estendido virado para cima, acompanhado pela palma da mão, e os dedos estendidos abertos em leque. O braço direito encontra-se atrás do corpo que está torcido para a direita, em um claro exagero da posição de épaulement ${ }^{74}$ (c). A cabeça encontrase inclinada para a esquerda e para trás, com projeção do queixo para o alto. A configuração do braço e da mão esquerda sugere a reprodução de uma estrutura indicando o ato de chamar alguém, porém sem "a flexão dos dedos em direção à palma da mão diversas vezes" (deJorio 2000, p. $124^{75}$ ), podendo essa flexão ser feita com todos os dedos ou apenas com o indicador (como na figura abaixo), ou, ainda, com uma possível flexão do cotovelo em casos de distância física entre os interlocutores dificultar a visão do gesto manual.

\footnotetext{
${ }^{73} \mathrm{O}$ exemplo de sala de aula foi retirado do vídeo Royal Ballet Daily Class, disponibilizado no endereço http://www.youtube.com/watch?v=5EVMjnHFg-w.

${ }^{74} \mathrm{O}$ épaulement é uma posição que implica uma leve torção do tronco, com consequente deslocamento de um dos ombros para frente em relação ao outro ombro. A cintura pélvica e as pernas mantêm uma posição central em relação à torção, não reproduzindo, portanto, a torção da cintura escapular.

75 In Wilcox, S. (2004). Gesture and Language: Cross-linguistic and historical data from signed languages. In Gesture 4:1 (2004) (pp.43-73). Amsterdam/Philadelphia: Johns Benjamin (p. 51).
} 


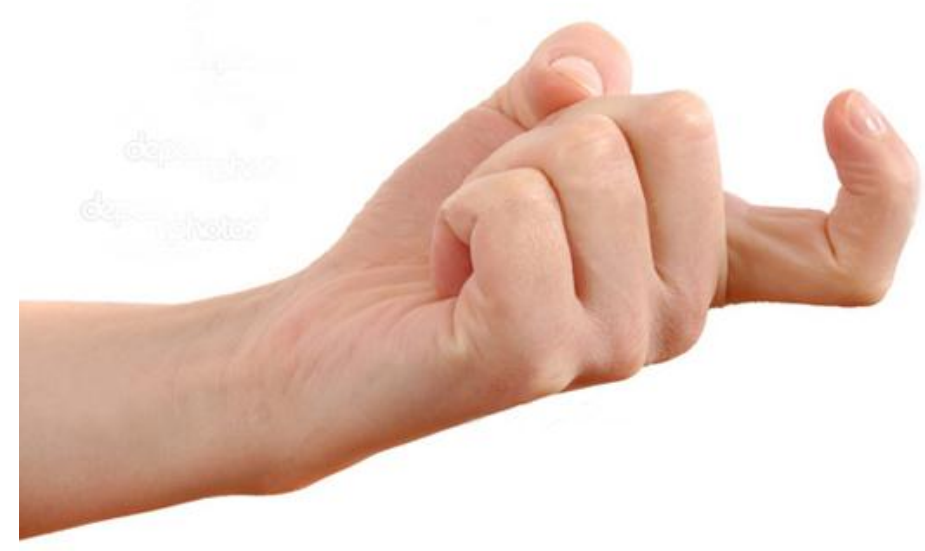

Figura 75. Exemplo de gesto utilizado cotidianamente para chamar alguém ${ }^{76}$

A configuração da mão de Romeu indica que a ação representada não está completa, exigindo, então, que se estabeleça algum tipo de relação entre o gesto e a ação, ou seja, já não a apreendemos diretamente a partir da imagem apresentada pelo gesto. Minha interpretação é a de que Romeu, nesse momento, sinaliza para que Julieta se aproxime. Em contexto de impossibilidade de fala, por excesso de barulho, por exemplo, essa ação seria realizada em sua forma completa. Como no caso da narrativa dançada também há ausência de fala, é possível supor que o sinal para aproximação fosse realizado em sua forma completa.

a)

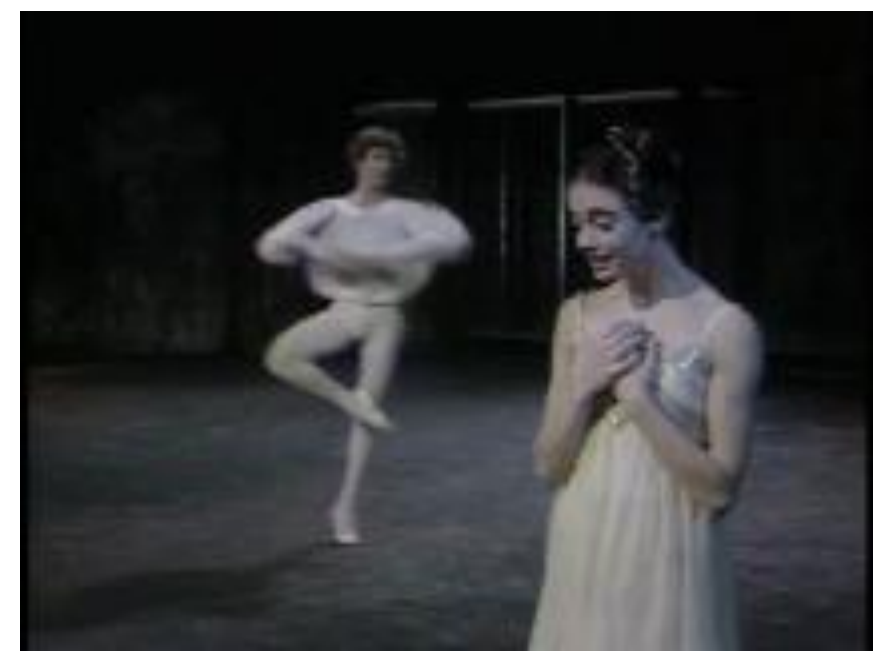

\footnotetext{
${ }^{76} \mathrm{O}$ exemplo foi retirado do endereço eletrônico http://www.loucoporviagens.com.br/2011/10/26/10gestos-comumente-mal-interpretados-no-exterior/.
} 


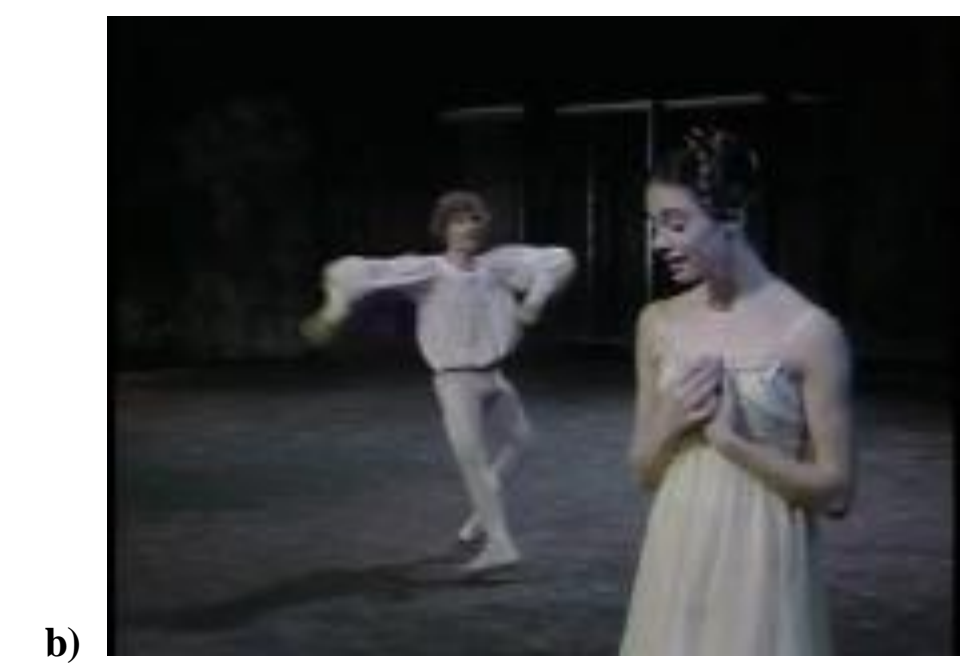

c)

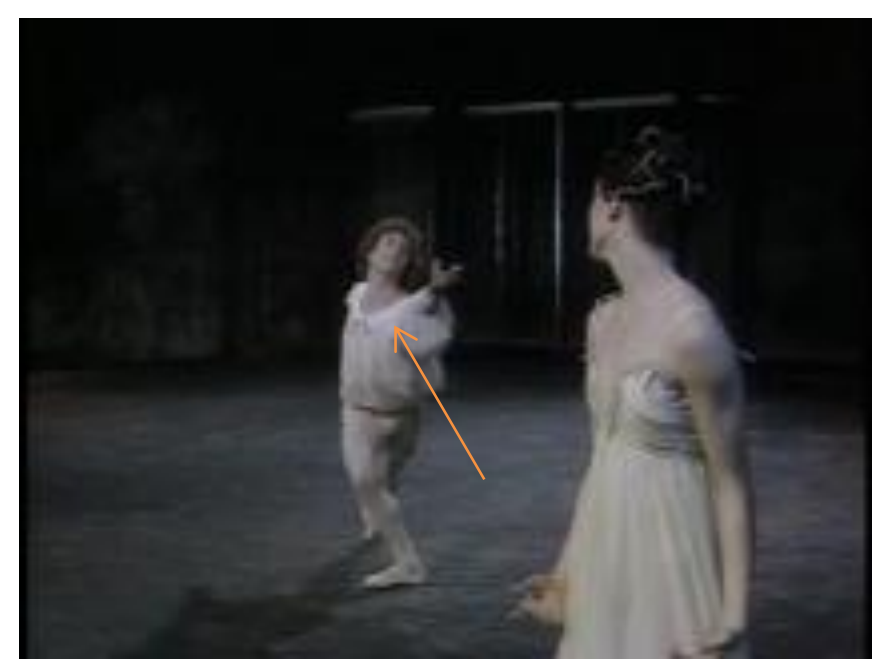

Figura 76. Exemplo de gesto icônico diagramático (cena do balcão). a) pirueta passé; b) início do gesto; c) posição final da pirueta e do gesto.

..1.....|Videos $\backslash$ Gestos Dissertação|Diagramático 3.wmv

Esse gesto é repetido por Romeu ao final de uma pirueta com a perna esquerda em attitude, na sequência coreográfica seguinte (a). Essa perna passa para frente da direita, em croisé para o público (b) e (c). O braço direito mantém uma segunda posição de braços (cf. figura 9), enquanto o braço esquerdo está com o cotovelo estendido e voltado para cima, assim como a palma da mão (d). Os dedos estão estendidos e abertos em leque. A cabeça encontra-se inclinada para a esquerda e para trás, e o olhar se dirige a Julieta que se encontra na parte da frente do palco, à direita. Por não ser um gesto convencionalizado na técnica clássica, está sendo tomado como pertencente ao nível gestual. 
a)

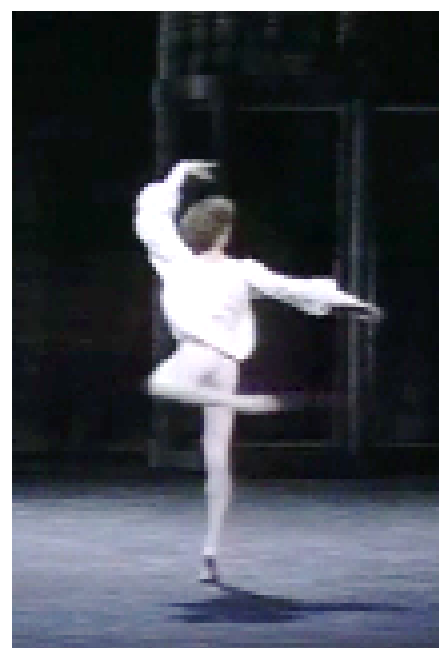

b)

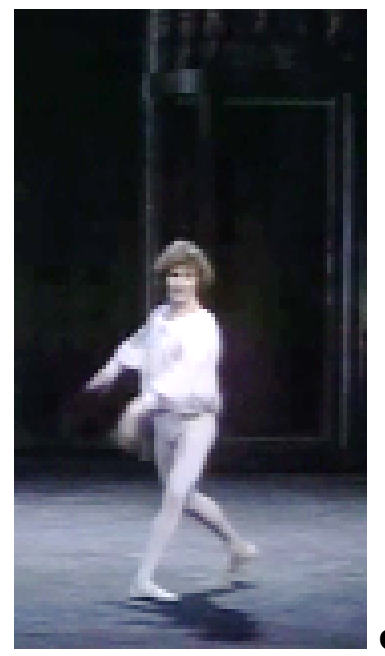

c)

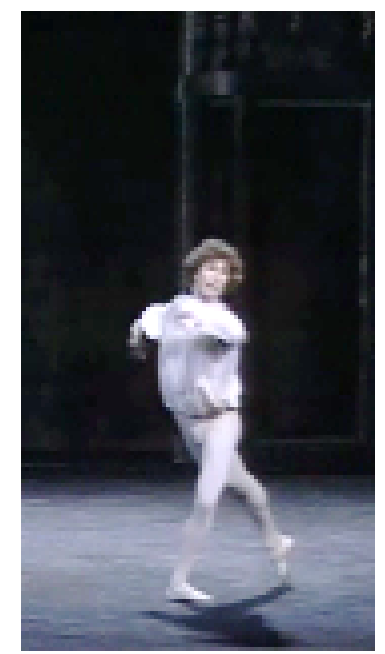

d)

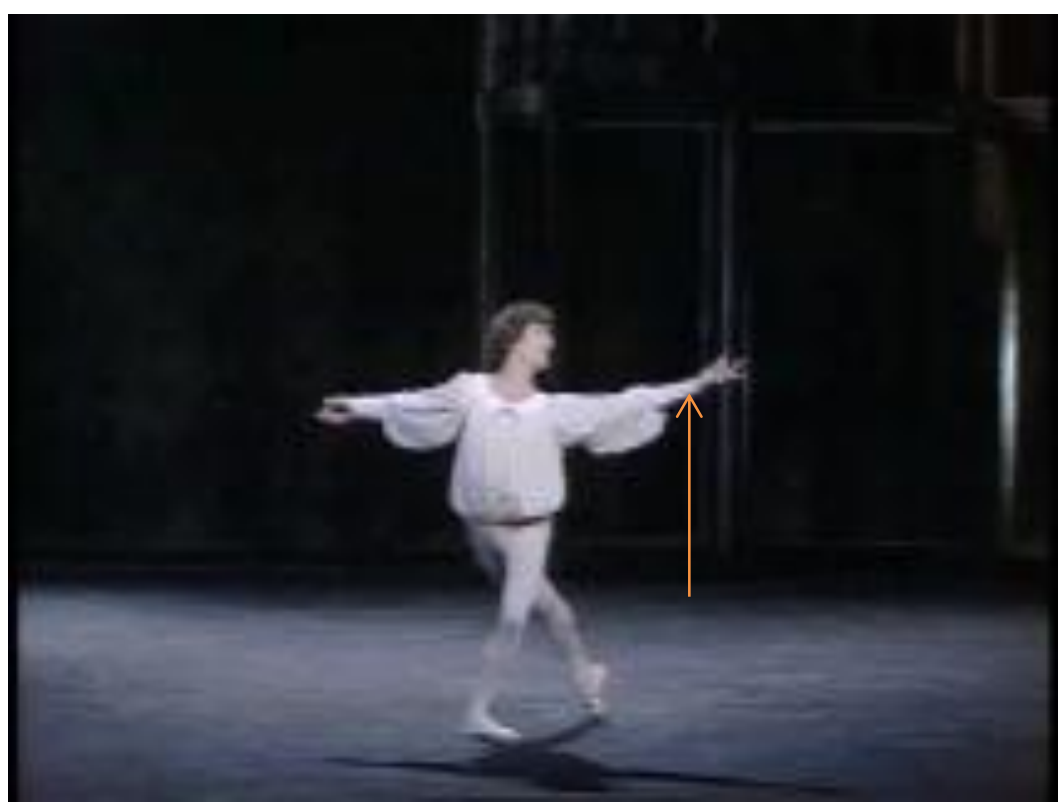

Figura 77. Exemplo de gesto icônico diagramático (cena do balcão). a) pirueta attitude; b) posição intermediária; c) início do gesto em quarta posição allongé croisé; d) posição final.

..1..1..|Videos\Gestos Dissertação|Diagramático 4.wmv

Esses dois últimos gestos podem ser interpretados como um convite de Romeu para que Julieta venha dançar com ele. A questão, nesse caso, é não haver uma dança conjunta na sequência da execução do gesto, nem em sua primeira ocorrência, nem na segunda. Também a configuração da mão não corresponde a outras ocorrências de um convite para dançar, presentes na cena do baile na versão inglesa, por exemplo, e reproduzidas abaixo. 

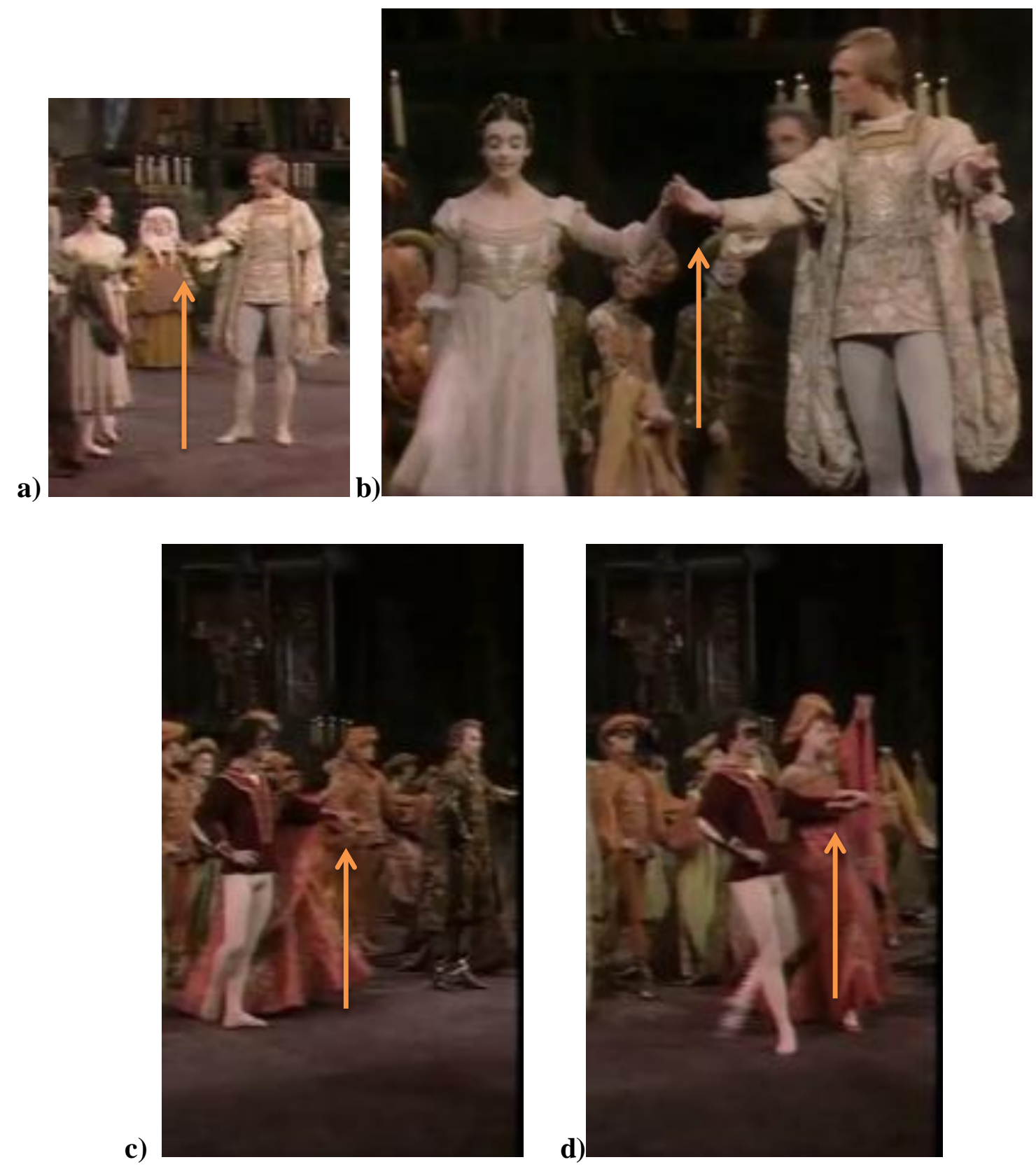

Figura 78. Exemplos de gesto de convite para dançar, retirados da cena do baile na versão inglesa. a) e b) palma da mão inclinada para cima; c) e d)palma da mão para baixo.

Em (a) e (b), a palma da mão, por exemplo, não está completamente voltada para cima e os dedos encontram-se relaxados na situação de convite, e não estendidos, como nos gestos realizados ao final das piruetas. Com relação à configuração do cotovelo, é possível levantar a hipótese de que o cotovelo de Romeu se encontra flexionado pela proximidade entre Paris e Julieta na cena do baile, ao passo que, nos exemplos de gesto diagramático, em que Romeu está distante de Julieta (figuras 76 e 77), seu cotovelo está estendido. Em (c) e (d), a palma da mão encontra-se em posição oposta àquela dos gestos diagramáticos, ou seja, completamente voltada para baixo, ainda que o convite faça parte de uma dança. Mas o ponto mais relevante parece ser o fato de que, feito o 
convite para dançar, há, na sequência, uma coreografia conjunta daquele que convida com a convidada. Nas duas ocorrências do gesto diagramático não há sequência de dança com os dois bailarinos; apenas Romeu continua a dançar. E, ao menos na primeira ocorrência, Julieta volta-se para Romeu, não havendo, portanto, uma situação em que a sequência de dança não ocorra porque Julieta não percebeu o convite feito por Romeu. A hipótese de a sequência de dança não ocorrer por timidez de Julieta fica um pouco comprometida pelo gesto icônico metafórico realizado por ela na primeira instância do gesto de Romeu, e interpretado como um oferecimento que ela faz de si mesma a ele. Também me parece que o gesto dêitico realizado por ela não se encaixa em um perfil de timidez, já que o gesto é realizado após o gesto de Romeu. Não há, tampouco, uma fuga ou retração do olhar de Julieta: quem rompe o contato visual é Romeu, pois ele volta a dançar.

Outra possível interpretação é a de Romeu estar chamando a atenção de Julieta para si, durante a coreografia, compatível com a primeira ocorrência do gesto. A maior dificuldade que vejo para essa interpretação, porém, é a ausência de um olhar anterior ao gesto, voltado para Julieta para verificar se ela está ou não olhando para ele, de modo a justificar a necessidade de chamar sua atenção na segunda ocorrência do gesto.

Assim, parece-me que a interpretação mais viável para esse gesto é a de que Romeu está chamando Julieta para perto de si, através de um gesto que representa a estrutura de um movimento usado para chamar alguém que se encontra à distância. Independentemente de qual seja o significado desse gesto, a ocorrência simultânea de passos técnicos e gesto corrobora uma vez mais a existência de uma estrutura tripartite no discurso dançado e a importância da interação entre os níveis para a composição do significado.

Dois outros exemplos de gesto icônico diagramático, retirados da cena do balcão, encontram-se ilustrados abaixo. O primeiro acontece quando Romeu beija a face de Julieta e ela coloca sua mão direita sobre a mão direita de Romeu, abraçando com a mão esquerda o braço de Romeu, cruzado na frente de seu corpo (figura 79). É possível propor que o abraço de parte representa o abraço do todo. 


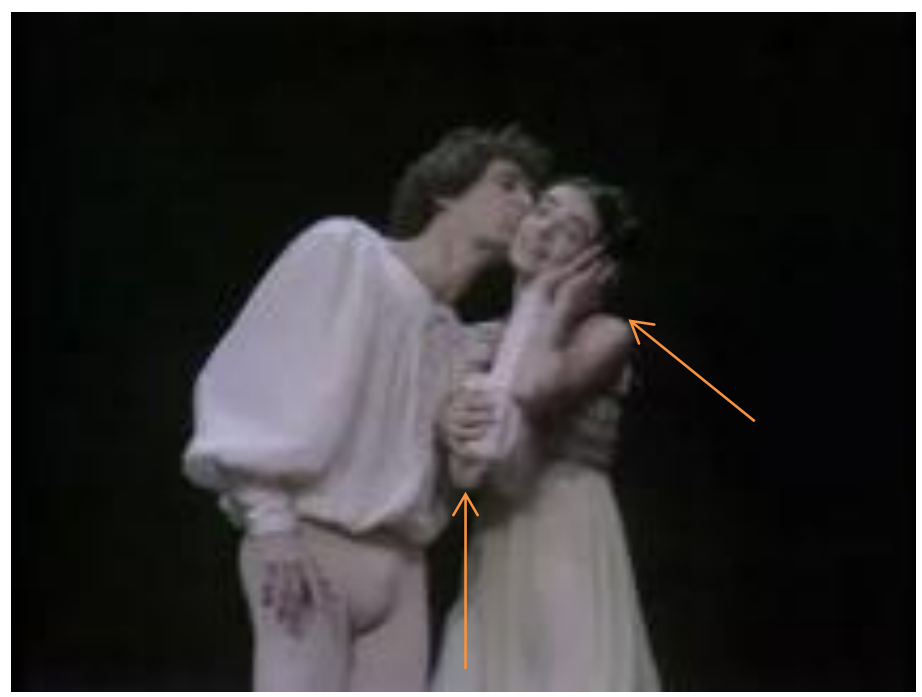

Figura 79. Exemplo de gesto icônico diagramático (cena do balcão). Julieta abraçando o braço de Romeu e segurando sua mão.

Quando Romeu sai para dançar a próxima sequência coreográfica, retirando a mão da face de Julieta, ela coloca a mão esquerda sobre a direita, que continuou no mesmo lugar, e corre em direção à diagonal direita frontal ${ }^{77}$ (figura 80). Dessa forma, ela estabelece uma relação entre a mão de Romeu e sua própria mão, como se a relação anterior de contiguidade permitisse a transposição da mão de Romeu para a mão de Julieta. Nessa transposição, ela traz Romeu consigo através de sua mão, ou seja, tomando uma parte pelo todo.

77 As relações espaciais aqui apresentadas levam em consideração a posição da plateia em relação ao palco italiano, como apresentado na figura 2 da seção 1.2.1.2. 


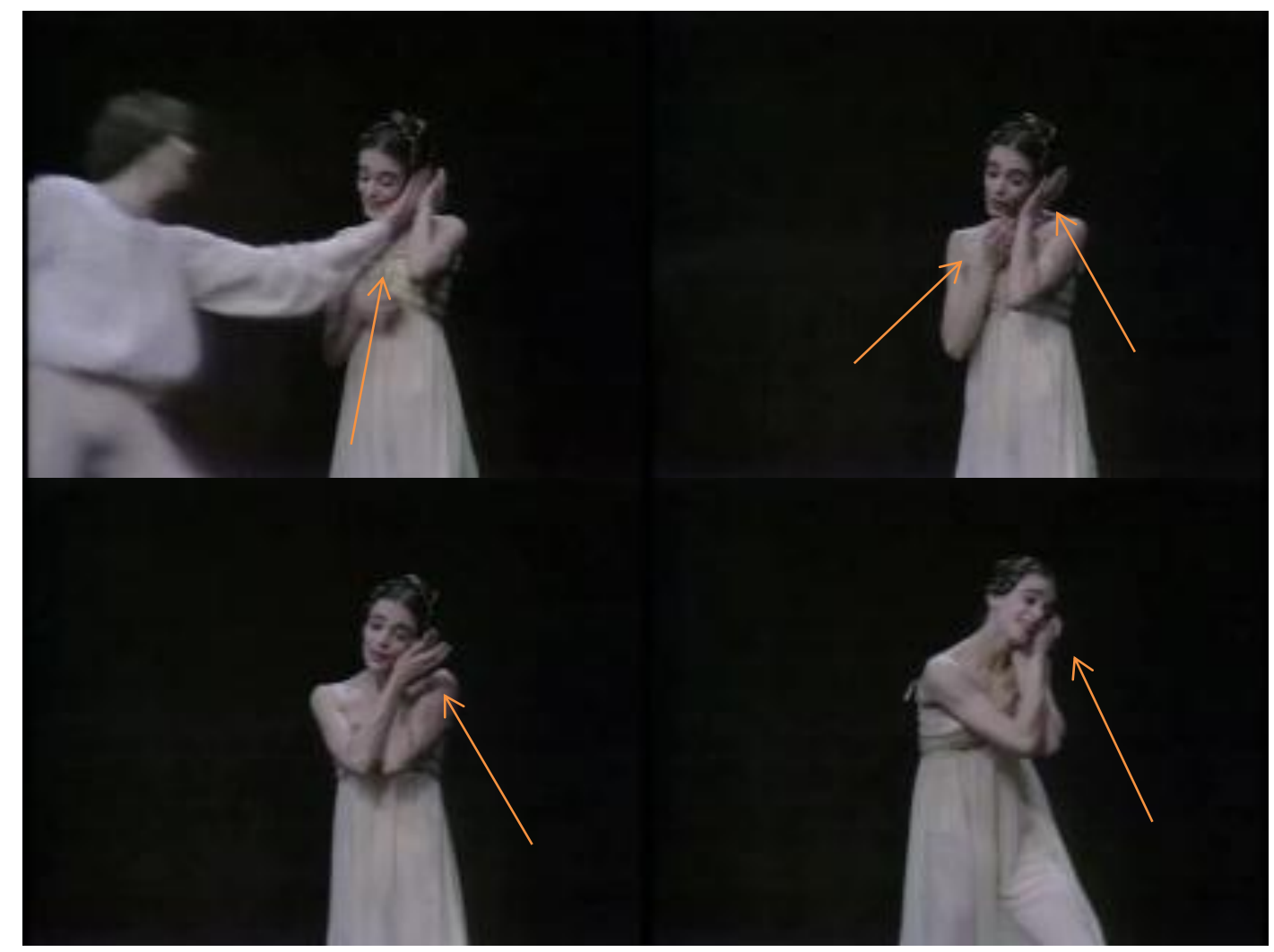

Figura 80. Exemplo de gesto icônico diagramático (cena do balcão). Julieta segurando uma mão com a outra. ........Videos\Gestos Dissertação|Diagramático 1b.wmv

Um abraço, apresentado acima com um gesto icônico imagético, também pode acontecer com uma representação diagramática (figura 81). Na versão inglesa, o abraço recebe uma representação diagramática da ação, na qual Julieta, após encontrar o corpo de Romeu no chão da cripta da família, percebe que o amante está morto. Julieta abraça apenas a cabeça de Romeu, que pode ser interpretada como a representação de seu corpo. Associada a esse gesto, há a expressão facial, com os olhos direcionados para uma diagonal baixa, que produz um gesto icônico metafórico, que pode ser interpretado como uma forma estabelecida para tristeza. Contribuem para a construção do significado desse sentimento a posição do corpo de Romeu no torso superior de Julieta, com seus braços pendidos ao lado do corpo, sua cabeça voltada para baixo, a posição inclinada para baixo da cabeça de Julieta e a posição assimétrica dos ombros de Romeu, com o ombro direito mais alto que o esquerdo, reproduzida em menor escala na assimetria da cintura escapular de Julieta. Ocorre aqui uma associação de gestos, produzidos simultaneamente por diferentes articuladores. 

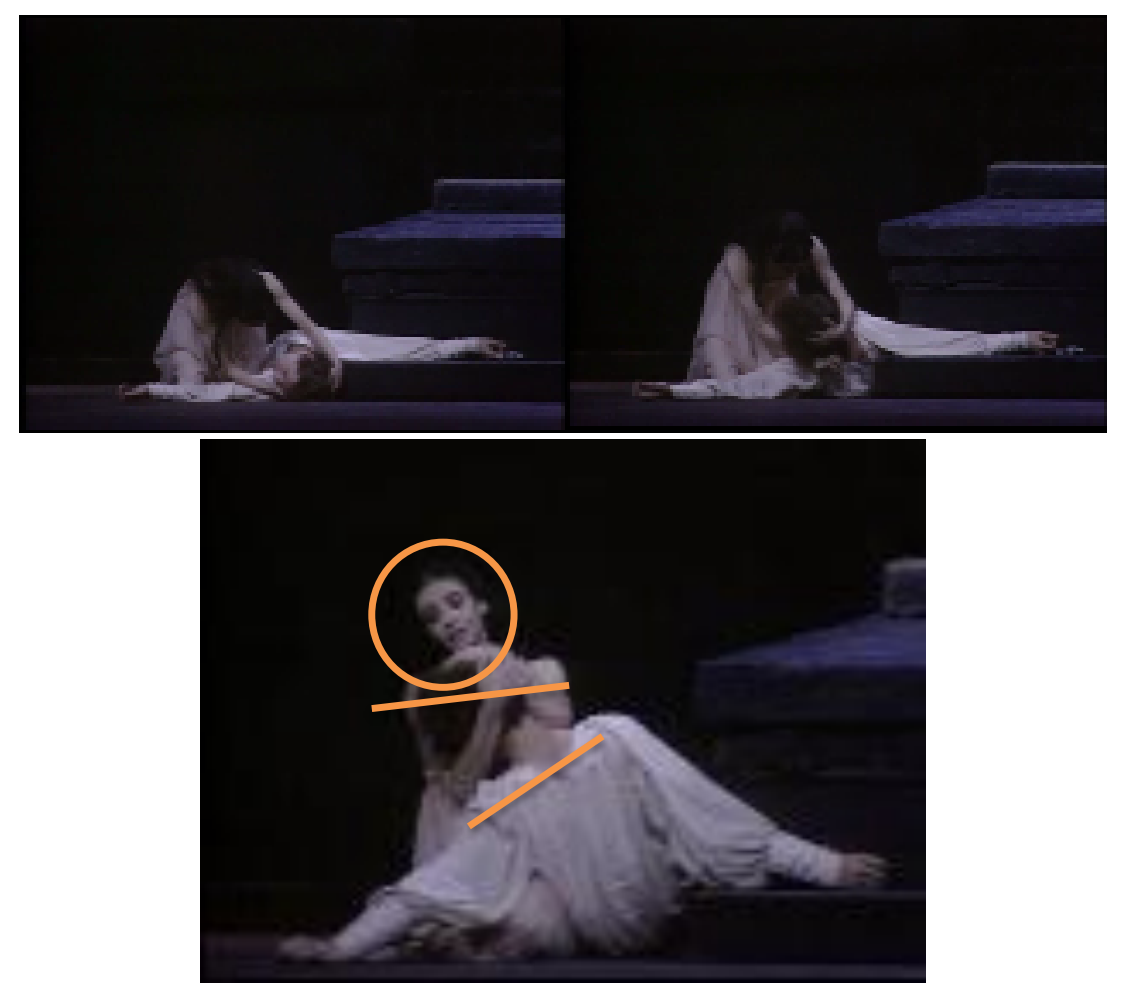

Figura 81. Abraço com gesto diagramático, retirado da cena final na versão inglesa. .........IVideos\Gestos DissertacãolAbraco Royal b.wmv

Outro exemplo de gesto icônico diagramático, também retirado da cena final na versão inglesa, apresenta o gesto realizado no momento imediatamente anterior à morte de Julieta (figura 82). Depois de apunhalar-se do lado direito da tumba, ela se arrasta sobre a superfície de pedra para encontrar Romeu, cujo corpo encontra-se do lado esquerdo do túmulo. Ao atingir o lado esquerdo, ela busca a mão de Romeu e a toma entre as suas. É possível sugerir que a parte (a mão) representa o todo (Romeu). Portanto, Julieta, ao tomar a mão de Romeu entre as suas, o está abraçando. Fica representada uma relação diagramática entre parte e todo. 


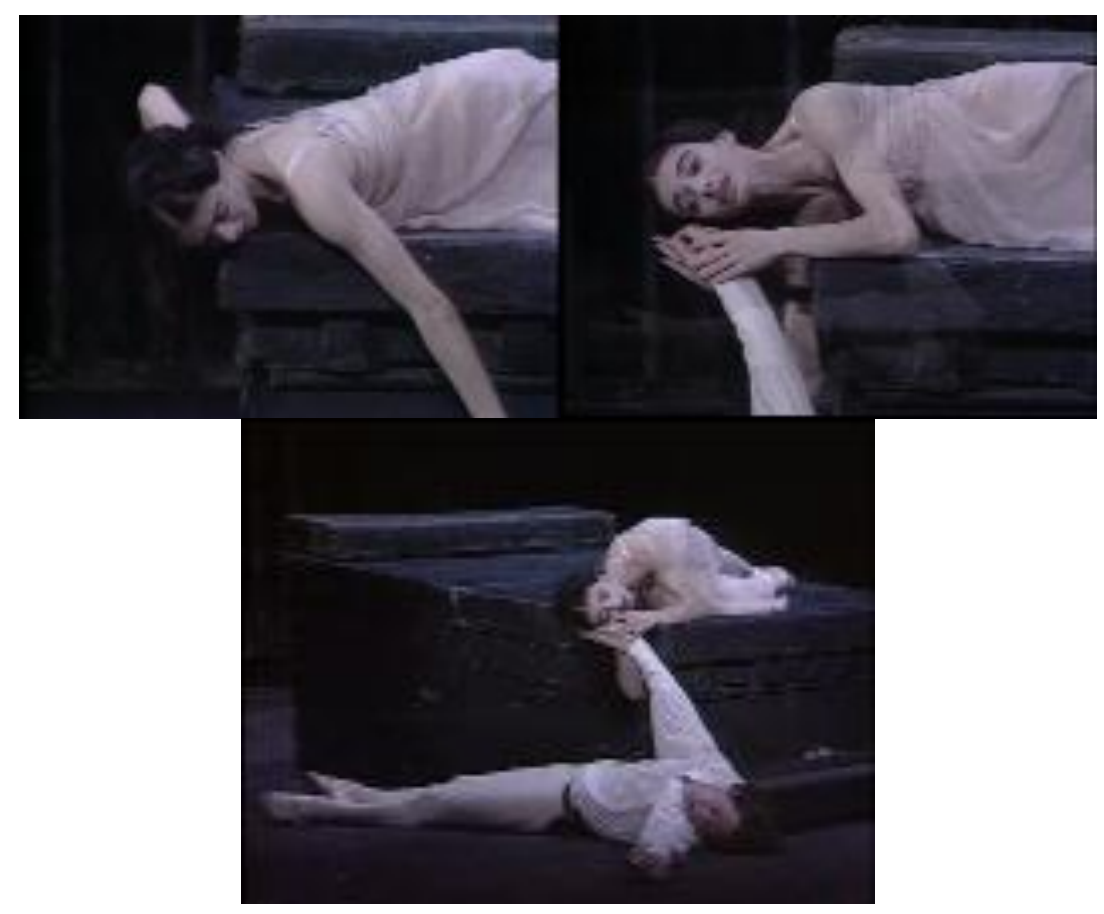

Figura 82. Exemplo de gesto icônico diagramático (cena final). ..1..1..|Videos\Gestos Dissertação|Diagramático 2.wmv

Na sequência abaixo, retirada da versão francesa, encontra-se outro exemplo de gesto icônico diagramático (figura 83). Há certos aspectos que são esperados quando vemos um beijo, para ser possível identificá-lo. Por exemplo, esperamos que os lábios de uma pessoa toquem uma parte do corpo de outra pessoa, podendo ser, entre outros, a face, o dorso da mão, o pescoço, sempre com os lábios fechados em posição protusa. No exemplo abaixo, a representação esquemática nos possibilita identificar um beijo, ainda que não haja a configuração canônica dos lábios nem o toque efetivo dos lábios, apenas sua sugestão.

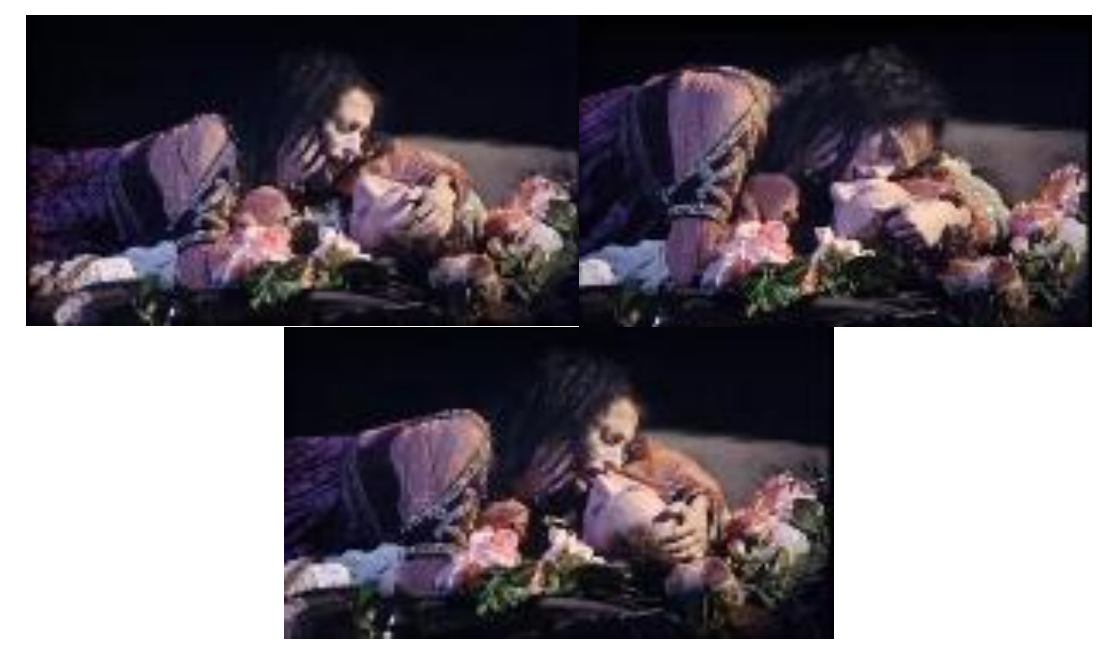

Figura 83. Exemplo de gesto icônico diagramático, retirado da cena final na versão francesa. ..1..1..|Videos \Gestos Dissertação|Diagramático 7.wmv 
Em praticamente todos os exemplos apresentados, o gesto diagramático é realizado em contexto de relação entre as duas personagens, quer na cena do balcão entre Romeu e Julieta, quer na cena final, entre Julieta e o corpo inerte de Romeu. A única instância analisada em que essa relação não é direta é aquela descrita no exemplo ilustrado na figura 80. No entanto, nesse exemplo, o gesto é produzido logo após o estabelecimento da relação entre a mão de Romeu e o rosto de Julieta, sendo, portanto, também fruto de uma relação entre os dois bailarinos. Essa representação de relações diádicas é parte da definição de diagrama, proposta por Peirce. A metonímia é o principal processo envolvido na categorização de gestos diagramáticos. No entanto, o primeiro e o último exemplos também pressupõem o processo de complementação das partes que compõem a estrutura da ação.

Os gestos produzidos junto com movimentos técnicos são realizados em diferentes partes das sequências. Na pirueta, o gesto tem início na passagem do passé para a quarta posição allongé final, e termina junto com o alongamento do joelho da perna que está atrás do corpo. Na pirueta em attitude, o gesto começa com a passagem da perna da posição no ar para a quarta posição allongé, mas termina depois que o alongamento da perna de trás já está completo. Isso talvez se deva ao fato de não ser necessário o realinhamento das cinturas escapular e pélvica ao final do passé, algo necessário no caso do attitude, pois o corpo tem que bascular para frente para que a perna possa chegar à posição atrás do corpo (assim como no arabesque). Com isso, o nível de controle e atenção na passagem para a quarta allongé fica aumentado por causa do realinhamento, o que pode explicar a realização posterior do gesto no segundo caso.

Com relação aos dispositivos simbólicos de Hanna (1990), a categoria dos gestos icônicos diagramáticos está diretamente relacionada à metonímia, enquanto movimento de algo representado por uma parte ou por associação a um mesmo quadro de referência. Já com relação à categorização de Humphrey (1959), os gestos icônicos diagramáticos não se encaixam em nenhuma das funções de maneira completa, justamente por seu caráter esquemático. O gesto presente no abraço da figura 81, por exemplo, receberia a mesma classificação do gesto icônico imagético da figura 72 , quando, claramente, a composição gestual implica diferentes processos de conceitualização. 


\subsection{Icônicos metafóricos}

Gestos icônicos metafóricos, como apresentados anteriormente, mapeiam conceitos abstratos em formas mais concretas, viabilizando sua representação. Por vezes, sua categorização torna-se mais complicada, pois parte dos articuladores produz uma imagem ou diagrama, enquanto a outra parte produz uma metáfora. Nem sempre é evidente a dimensão semiótica que terá precedência. A análise busca ressaltar os elementos mais proeminentes para poder sugerir uma classificação.

Apresento, a seguir, alguns exemplos de gestos que estou considerando metafóricos. O primeiro deles é o gesto de braços realizado por Julieta ao descer as escadas para encontrar Romeu no pátio durante um grand jeté. O grand jeté, como já mencionado, é um grande salto da técnica clássica, realizado pela elevação de uma perna à frente do corpo impulsionando-o para o alto, possibilitando a elevação da outra perna atrás do corpo, para a finalização em attitude ou arabesque (cf. figura 17). Os braços que tecnicamente acompanham esse grande salto são os de segunda posição (cf. figura 9), terceira posição (cf. figura 10), quinta posição (cf. figura 12) ou braços de arabesque, conforme figura abaixo.

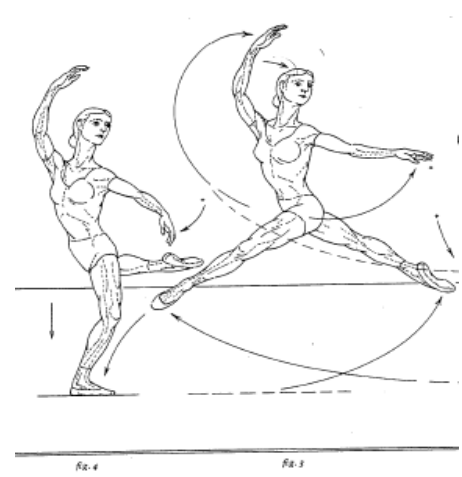

a)

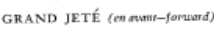

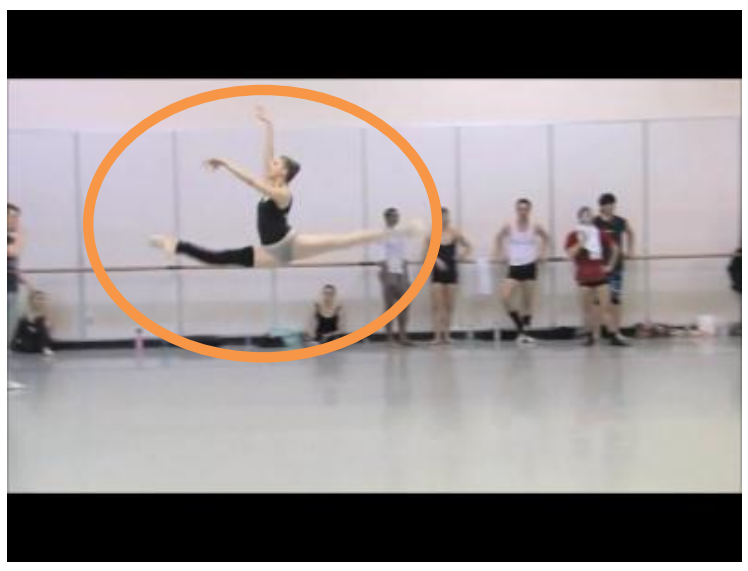

b)

Figura 84. Exemplos de grand jeté. a) com braços em terceira posição ${ }^{78}$; b) em arabesque ${ }^{79}$

No exemplo retirado da cena do balcão, os braços se encontram em uma posição próxima da quinta, mas não realizada como uma quinta posição canônica de braços. Essa postura de braços é encontrada na mesma cena, mais adiante, associada a uma

\footnotetext{
${ }^{78}$ A ilustração foi retirada de Kirstein, Stuart e Dyer (1952), página 171.

${ }^{79} \mathrm{O}$ exemplo de sala de aula foi retirado do vídeo Royal Ballet Daily Class, disponibilizado no endereço http://www.youtube.com/watch?v=5EVMjnHFg-w.
} 
expressão facial de felicidade, o que me leva a considerá-lo uma representação concreta dessa emoção, já que esse primeiro momento também é feliz.

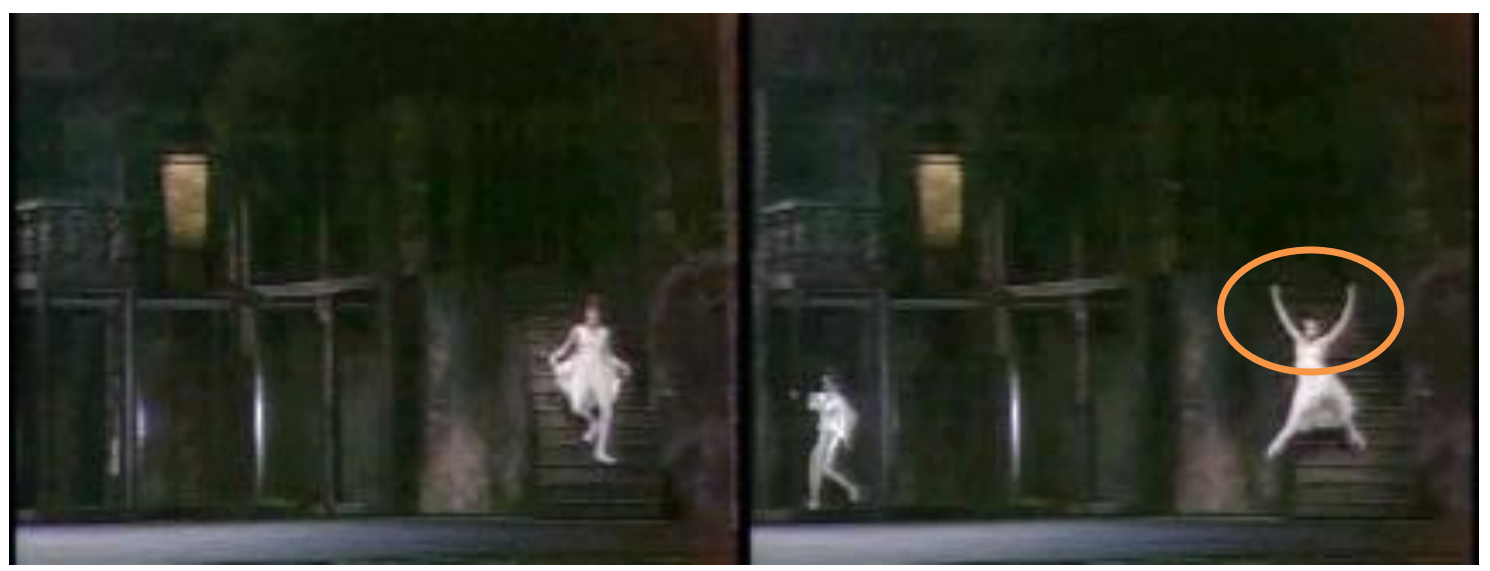

Figura 85. Exemplo de gesto metafórico com grand jeté. ..1.....IVideos\Gestos DissertacãolMetafórico 1.wmv

$\mathrm{Na}$ foto abaixo (figura 86), retirada da versão de MacMillan dançada por Margot Fonteyn e Rudolf Nureyev, não há ocorrência do grand jeté, e a configuração dos braços sugere um gesto icônico metafórico que pode ser interpretado como uma representação de pressa ou rapidez. A bailarina realiza a descida das escadas até o final, trazendo o braço direito na lateral do corpo e o braço esquerdo levemente atrás do corpo.

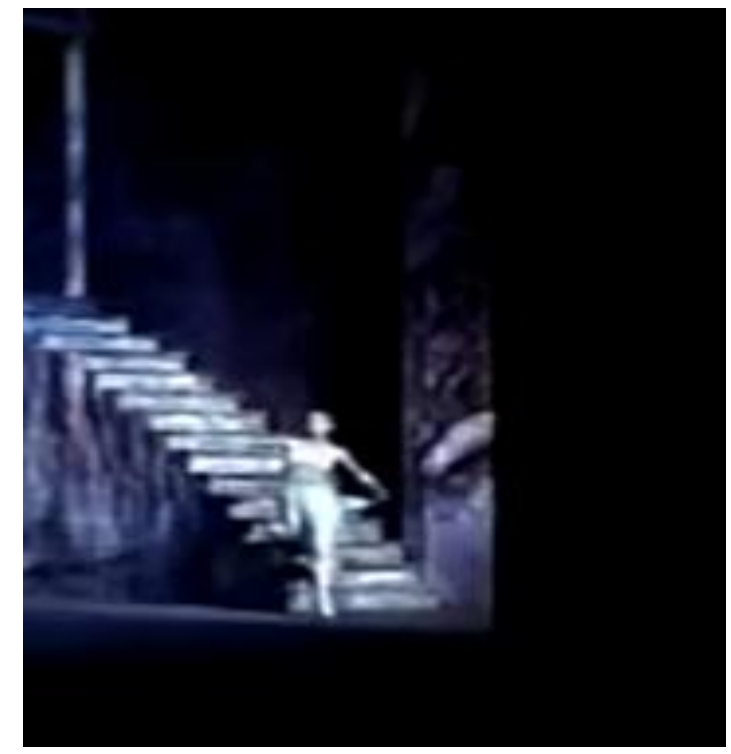

Figura 86. Descida da escada na versão de Fonteyn e Nureyev

A outra ocorrência do gesto acontece mais adiante na cena, em um arabesque, executado após um porté, que vem a ser um passo em que a bailarina é sustentada no ar pelo bailarino (figura 87). Novamente os braços assumem uma postura próxima da 
quinta posição, porém mais aberta. Ambos os bailarinos trazem uma expressão facial de felicidade, com a boca em configuração de sorriso. Uma vez mais, temos a associação de um gesto ao nível técnico.

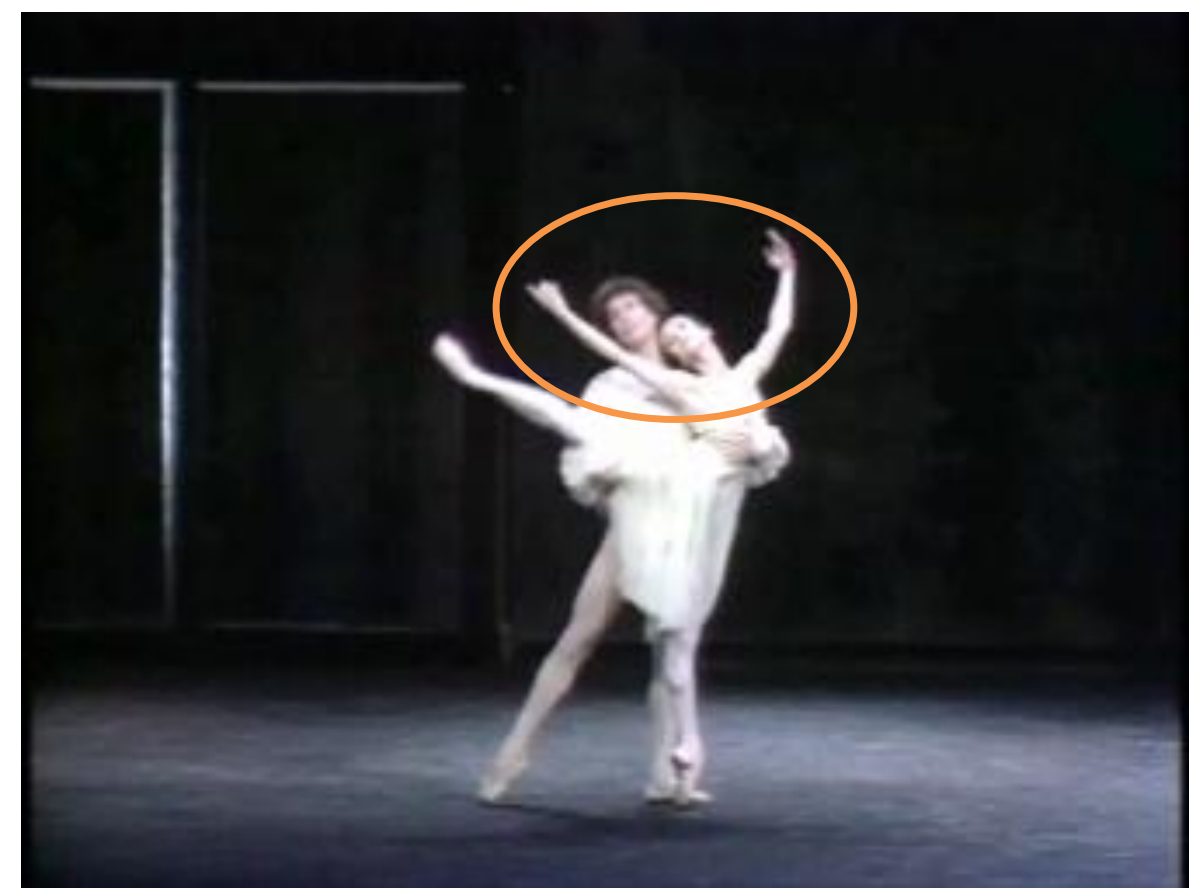

Figura 87. Exemplo de recorrência de gesto icônico metafórico com arabesque.

..1.....|Videos\Gestos Dissertação|Metafórico 1b.wmv

Outro exemplo de gesto icônico metafórico é aquele realizado por Romeu ao final de uma pirueta passé en dehors (figura 88). Como mencionado acima, dentro da técnica clássica, as piruetas terminadas em posições abertas de pés tendem a ser finalizadas com posições abertas de braço. No caso, a pirueta é finalizada com um degagé en arrière ouvert, uma posição aberta de pés, porém os braços assumem uma posição não padrão, realizando um gesto. A configuração de suporte da mão do bailarino, com a palma voltada para cima, o movimento descrito por essa mão para chegar ao ponto final (uma linha reta entre seu peito e o fim do movimento, sempre com a palma da mão voltada para cima) e a interação entre a mão de Romeu e o olhar de Julieta sugerem a entrega de algo ${ }^{80}$. Essa interpretação passa pela percepção da estrutura diagramática observada na configuração manual, em que a posição de suporte pressupõe um objeto apoiado sobre a palma da mão. O gesto dêitico de Julieta reforça a conceitualização de um objeto sobre a palma da mão.

\footnotetext{
${ }^{80}$ A configuração manual com a palma da mão para cima, conhecida como PUOH (palm-up open-hand), é bastante comum em contextos variados, tendo significados diferentes, mas de alguma forma interrelacionados, formando uma família gestual, segundo proposta de Müller 2004.
} 
Seguindo a proposta de Mittelberg e Waugh (2009), na qual o processo metonímico precede o processo metafórico, sugiro que a partir da inferência metonímica do objeto seja possível fazer o mapeamento metafórico da emoção. Pelo enredo sabemos que Romeu e Julieta estão apaixonados um pelo outro; dessa forma podemos imaginar que o objeto entregue seja sua emoção. Há, portanto, uma construção metafórica sobre a apreensão de uma estrutura diagramática ${ }^{81}$.

Uma possibilidade de entender que uma emoção possa ser tomada por um objeto a ser entregue a alguém existe por conta das metáforas ontológicas. Segundo a Teoria de Metáforas Conceituais (introduzida na nota 34), essas metáforas são modos de ver entidades, atividades, emoções, ideias, etc., como objetos e substâncias. Ou seja, a partir de nossas experiências com objetos e substâncias, podemos tomar parte de nossas experiências e tratá-las como entidades discretas ou substâncias uniformes (Lakoff e Johnson 1980, p. 25). Um exemplo é a inflação, que se torna uma entidade ligada à experiência de aumento de preço, permitindo que possamos nos referir a ela, quantificála, identificar um aspecto específico dela, entre outras possibilidades. No caso do gesto examinado, torna-se possível conceitualizar a emoção como um objeto que está sendo sobre a palma da mão, através da metonímia, e conferir a esse objeto propriedades da emoção de Romeu, através de processo metafórico, baseado na metáfora EMOÇÃO É OBJETO $^{82}$. É possível traçar um paralelo para o uso que fazemos dessa metáfora na linguagem cotidiana, como, por exemplo, em Maria ofereceu sua solidariedade, Minha amizade por João é a coisa mais linda do mundo, Esse menino só me dá alegria.

\footnotetext{
${ }^{81}$ Lakoff e Johnson (1980) apresentam a metonímia servindo a alguns dos mesmos propósitos da metáfora, como, por exemplo, uma entidade ser usada para se referir a outra, com a diferença de que através da metonímia apontamos para os aspectos do referente que queremos enfatizar, já que a metonímia PARTE PELO TODO não determina que partes serão selecionadas para a representação (pp. 36 e 37).

${ }^{82}$ De acordo com a Teoria das Metáforas Conceituais, a grafia dessas metáforas é feita em caixa alta para diferenciá-las das metáforas linguísticas.
} 


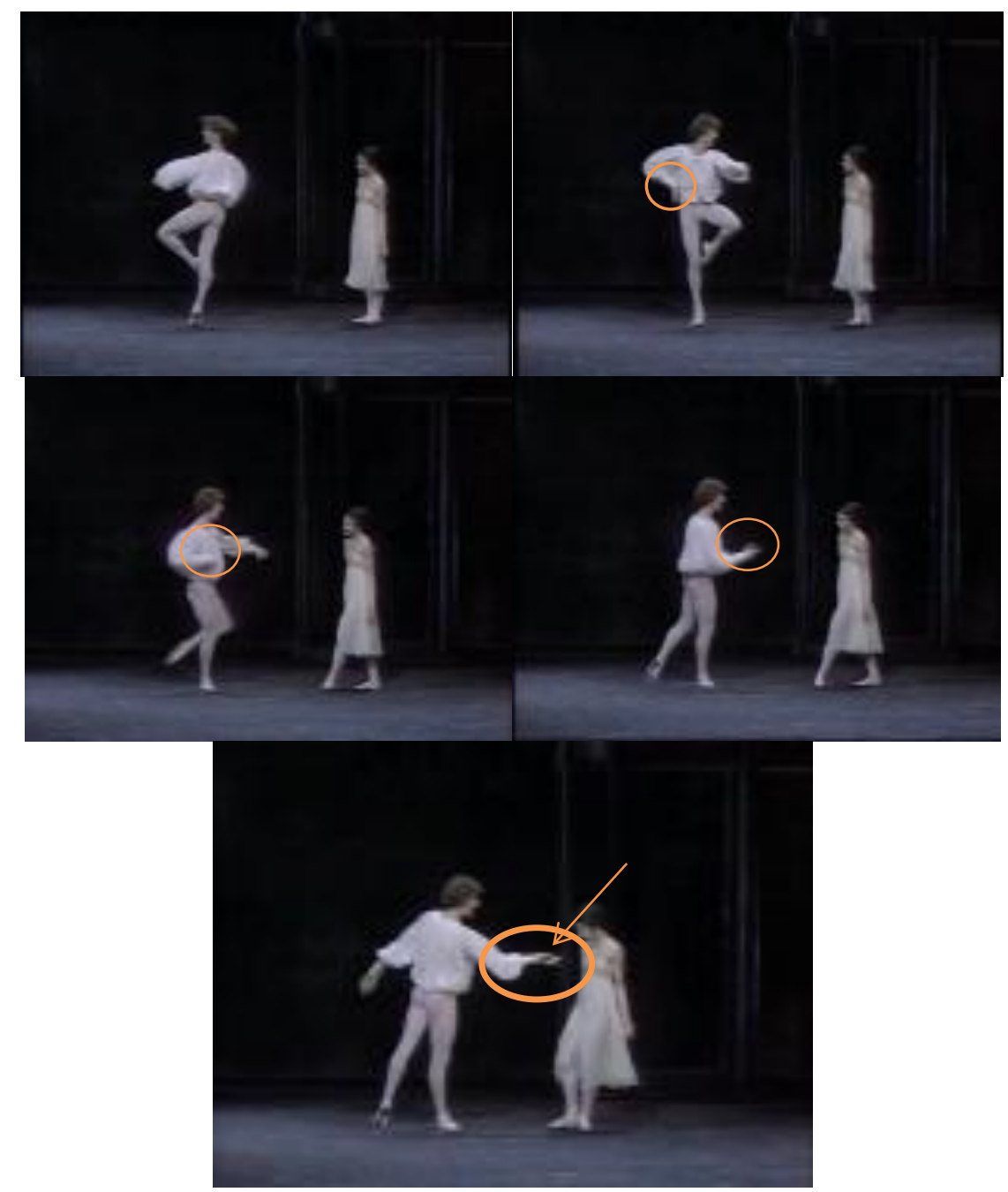

Figura 88. Exemplo de gesto icônico metafórico em final de pirueta passé (cena do balcão) .....1..IVideos\Gestos DissertaçãolMetafórico 2.wmv

Como já visto anteriormente, outra possibilidade de análise para esse exemplo seria a de Romeu estar chamando Julieta para vir dançar com ele, oferecendo-lhe a mão. A classificação poderia ser, então, a de um gesto icônico metafórico, no qual a mão sustenta o convite. Assim como em um dos gestos diagramáticos analisado acima, o problema que vejo para essa interpretação é a falta de uma sequência de dança conjunta que justifique essa possibilidade de extensão.

Ainda na cena do balcão, outra ocorrência de gesto icônico metafórico pode ser observada na realização grand rond de jambe en l'air por Julieta. Esse movimento tem início com a perna posicionada na frente do corpo, no ar, sendo levada, na sequência, para a lateral do corpo até chegar à posição atrás do corpo, sempre com a perna estendida, conforme ilustração abaixo. O corpo deverá se inclinar levemente para frente para a passagem da perna da lateral para trás, assumindo a postura prevista para o arabesque. 


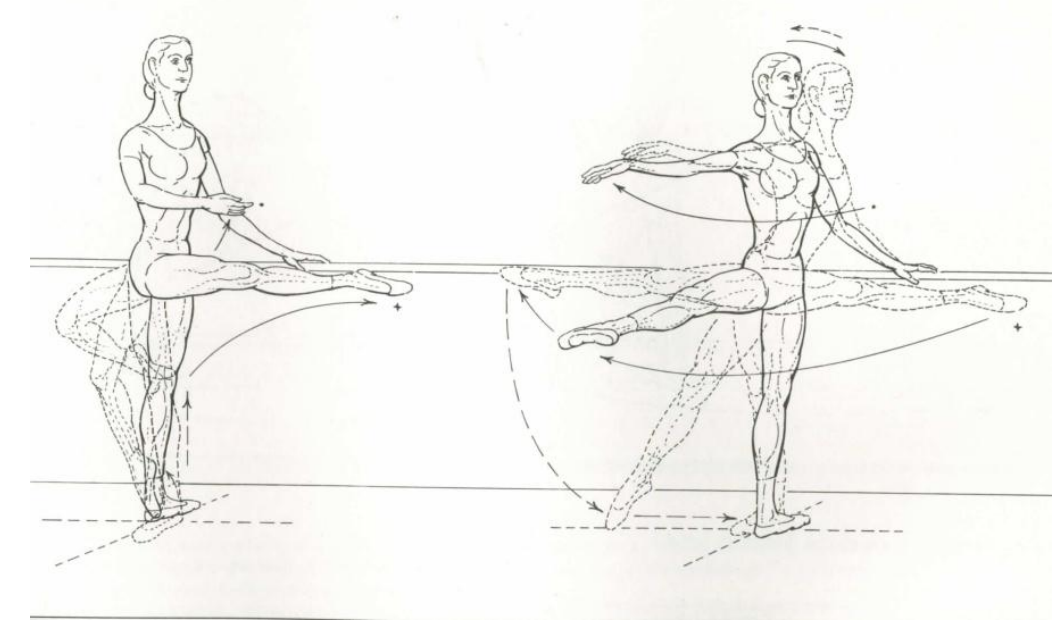

Figura 89. Grand rond de jambe en l'air realizado com o apoio da barra, retirada de Kirstein, Stuart e Dyer (1952, p. 71).

Como se pode observar na ilustração, uma possibilidade de movimento dos braços é levá-los da primeira para a segunda posição (levando-se em conta que o movimento da ilustração está sendo realizado com o apoio da barra). Os braços também podem ir para a quinta posição e terminar o movimento em uma posição de arabesque. Julieta, no entanto, ao realizar o movimento de pernas referente ao grand rond de jambe en l'air, faz um movimento não canônico com os braços, que interpreto como um gesto icônico metafórico. Ao iniciar o movimento de rotação da perna direita, a bailarina tem os dois cotovelos flexionados virados para cima, com os punhos levemente flexionados em direção à palma, dedos relaxados e palma da mão virada para cima, braços posicionados na frente do corpo. Quando a perna é levada para a lateral, os braços se abrem para a segunda posição de braços, mantendo, no entanto, sua configuração anterior. A cabeça é inclinada para trás na passagem da perna da frente para a lateral. Esse movimento é realizado no primeiro momento em que Julieta dança com Romeu, depois que ele dançou sua declaração a ela, através de uma sucessão de passos da técnica clássica combinados com gestos dêiticos, icônicos diagramáticos e icônico metafóricos. A perna em movimento ascendente e a cabeça de Julieta voltados para cima sugerem a metáfora conceitual ALEGRIA É PARA CIMA. Essa metáfora conceitual é do tipo orientacional, isto é, baseia-se em nossas experiências corporais com relação à orientação espacial (frente, atrás, cima, baixo, direita, esquerda, etc.). Na linguagem cotidiana, ela encontra-se traduzida em sentenças como Depois do nascimento das gêmeas, ela parece estar nas nuvens, O técnico fez um discurso pra levantar o moral dos jogadores, A boa notícia me deixou nas alturas. No caso da versão observada, a felicidade presente na expressão facial fica reforçada pelo gesto dos 
braços, que pode ser interpretado como se o sentimento estivesse sendo carregado nos braços e nas mãos voltadas para cima, representando, então, a metáfora ontológica EMOÇÃO É OBJETO. Ao terminar o grand rond de jambe com a perna atrás do corpo, a bailarina assume uma posição canônica de braços de arabesque.

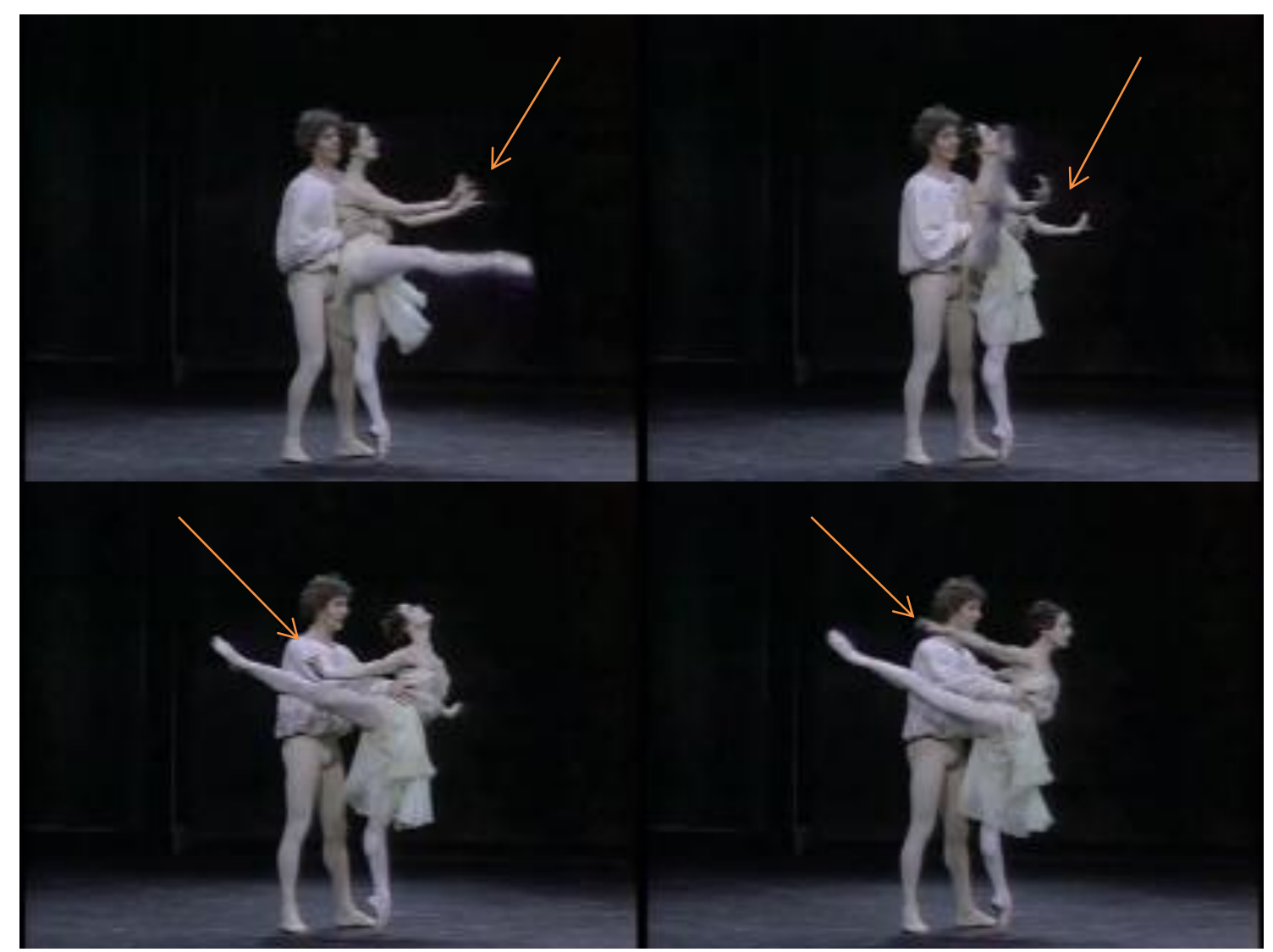

Figura 90. Exemplo de gestos icônicos metafóricos (cena do balcão), baseados na metáfora orientacional ALEGRIA É PARA CIMA (perna direita e cabeça) e na metáfora ontológica EMOÇÃO É OBJETO (braços e mãos). ........ Videos \Gestos Dissertação\Metafórico 3.wmv

Esses exemplos demonstram a importância do nível gestual para a semântica do discurso dançado. As extensões metafóricas presentes nos gestos conferem um significado mais concreto ao nível técnico.

No âmbito da pantomima, também é possível observar o uso de gestos icônicos metafóricos. Por exemplo, na cena final, logo depois de acordar e se localizar no espaço, Julieta realiza um gesto dessa categoria, ainda sobre a tumba. Ela lança os braços para a lateral do corpo, com os cotovelos flexionados para frente, os punhos levemente flexionados em direção às palmas e as mãos com as palmas viradas para baixo, acima da altura dos ombros. Ao passar os braços para trás do corpo, ela inclina o torso e a cabeça para trás, elevando os antebraços com os cotovelos flexionados, os punhos levemente flexionados em direção ao torso da mão, dedos relaxados e palmas 
das mãos viradas para fora. Essa configuração de braços e mãos não corresponde a nenhuma postura convencionalizada pela técnica clássica. É possível assumir que a configuração represente a surpresa de Julieta ao perceber que está na cripta da família.

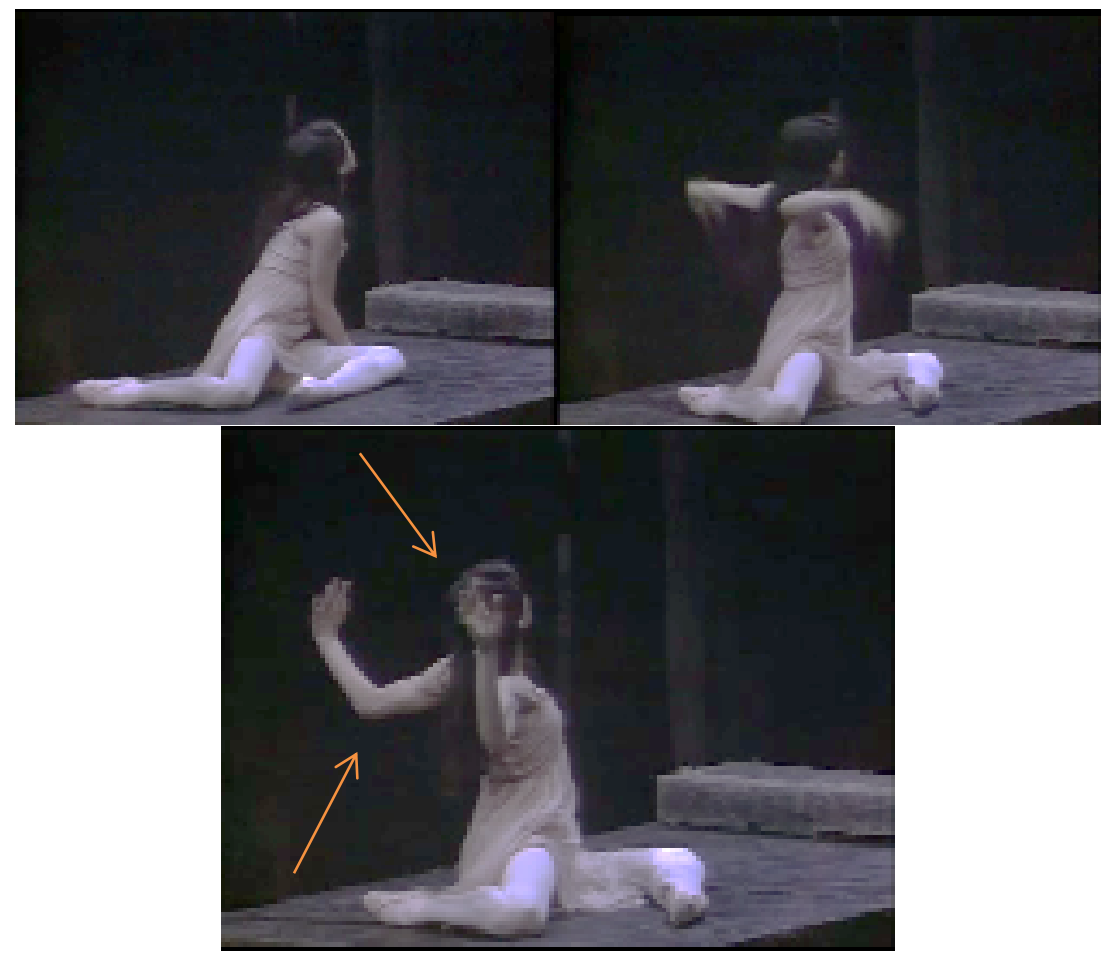

Figura 91. Exemplo de gesto icônico metafórico (cena final), realizado com os braços. ........Videos\Gestos DissertaçãolMetafórico 4.wmv

Um exemplo de gesto icônico metafórico é o do grito, representação de uma reação fisiológica do corpo a um estímulo de dor, que se torna uma forma para a dor. A extensão metafórica é possível devido ao desenvolvimento narrativo, já que o gesto é realizado após o encontro do corpo morto de Romeu, e à configuração dos articuladores. Os lábios arredondados em abertura máxima, as sobrancelhas erguidas, os olhos se fechando à medida que a cabeça é inclinada para cima e para trás e os ombros jogados levemente para frente são traços que compõem esse gesto, na cena final da versão inglesa. Ele é realizado em um lento movimento ascendente, na sequência do abraço, realizado com um gesto diagramático de braços e analisado acima. 


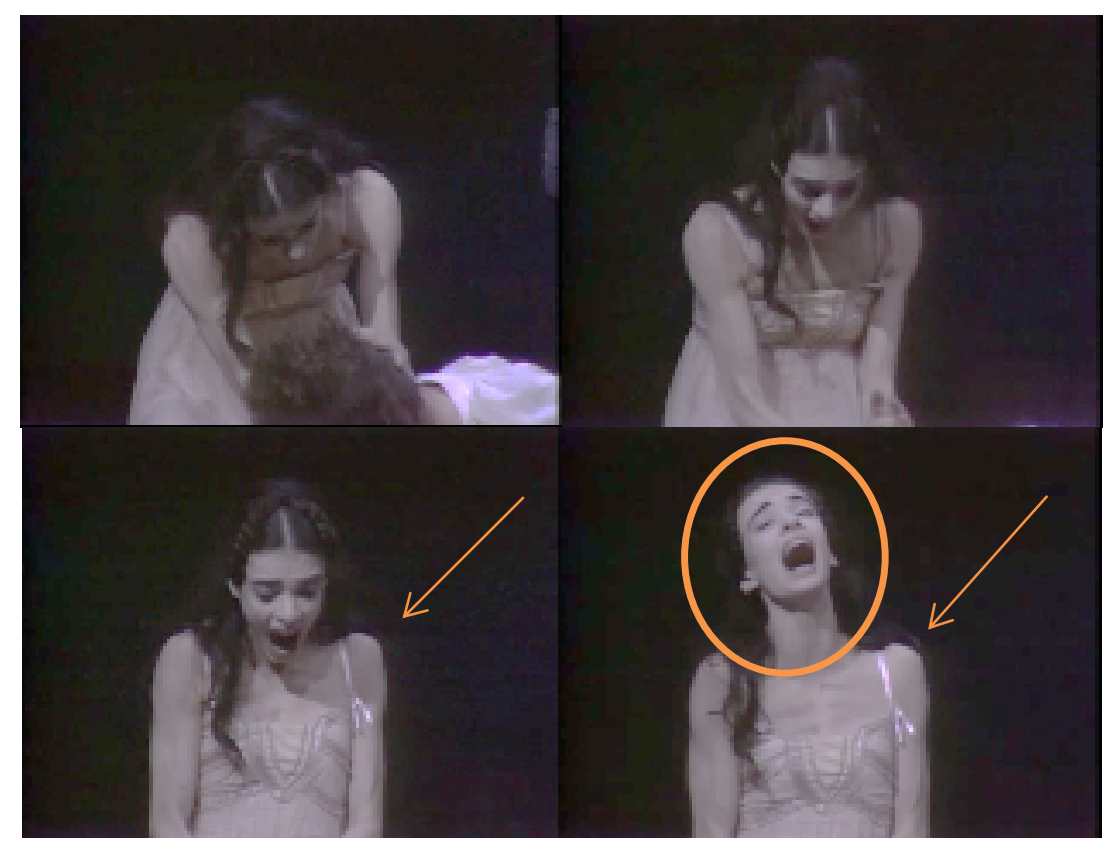

Figura 92. Gesto icônico metafórico retirado da cena final na versão inglesa, realizado com a cabeça, face e ombros. ........ Videos $\backslash$ Gestos Dissertação\Metafórico 4a.wmv

Na versão francesa, o movimento ascendente é rápido e seguido por movimento pivotal do corpo da intérprete, repetido de um lado a outro, nove vezes. A cabeça também está inclinada para cima, mas em um ângulo mais acentuado do que na versão inglesa. Os olhos fechados bem apertados, a testa franzida, os lábios arredondados em abertura máxima são traços que compõem a expressão facial. Aliadas a esses componentes há, ainda, as mãos fechadas segurando o vestido, à altura do ventre, e a posição do corpo, levemente inclinado para frente, com os ombros também voltados para frente.

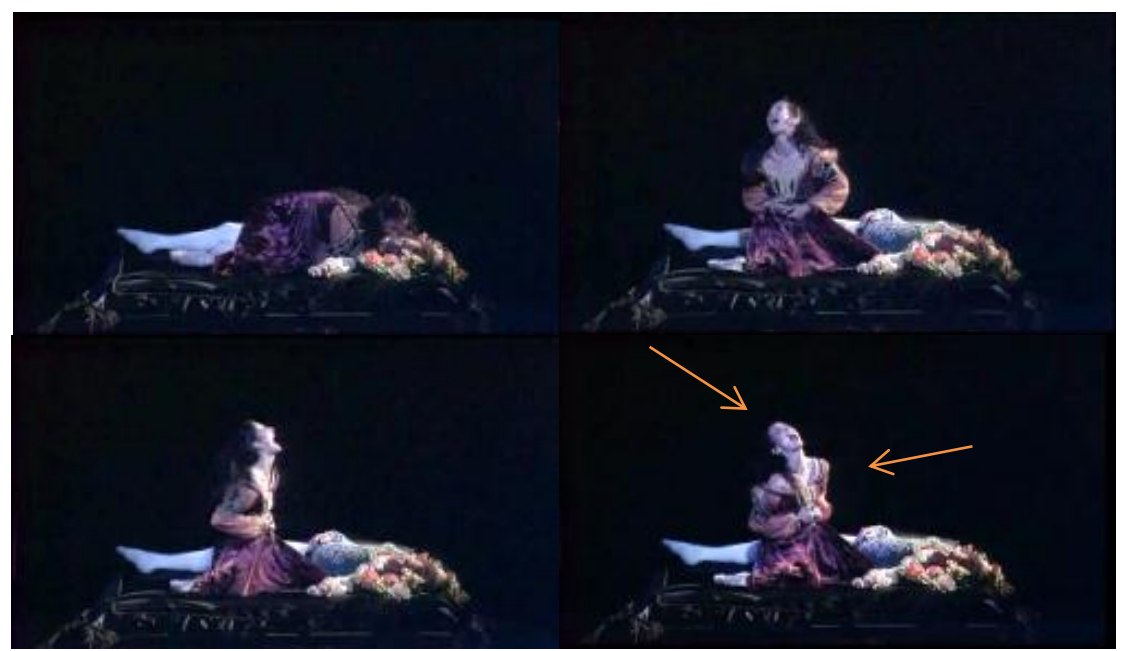

Figura 93. Gesto icônico metafórico retirado da cena final na versão francesa, realizado com a cabeça, face, corpo e mãos.

.......Videos|Gestos DissertaçãolMetafórico 4b.wmv 
O movimento completo na versão francesa é realizado em 0:03.130, ao passo que, na versão inglesa, ele dura 0:05.340. Daí é possível perceber o uso da paraquinese em associação ao componente gestual, gerando signos de diferentes interpretações: um coreógrafo opta por um movimento rápido, provocando a sensação de brevidade, enquanto o outro concebe o gesto mais lento, estendido no tempo. Também a diferença entre os componentes gestuais de inclinação de cabeça e corpo contribuem para uma leitura distinta das imagens. Na versão francesa, a posição do corpo, inclinada para frente, leva a uma postura de cabeça mais inclinada, como forma de manutenção do equilíbrio entre cabeça e tronco. Esse exemplo também demonstra os diferentes níveis envolvidos na construção do discurso dançado. As escolhas gestuais mostram a diferença entre a conceitualização de Julieta por parte de McMillan e de Nureyev, confirmando a exacerbação de características, como mencionado nos comentários sobre o processo criativo dos coreógrafos.

De acordo com a classificação de Hanna (1990), tanto o gesto da figura 92 quanto o gesto da figura 93 poderiam ser considerados estilizações, a partir de reações fisiológicas. No entanto, poderiam também ser concretizações para a metáfora de dor associada aos gestos. Na classificação de Humphrey (1959), os gestos da figura 92 e 93 estariam dentro da categoria de gestos emocionais, com padrões de movimento associados ao luto, como o corpo côncavo (figura 92) e o balanço lateral do corpo (figura 93), correspondendo ao momento da narrativa no qual os gestos se inserem.

Um exemplo de gesto icônico metafórico retirado da cena final da versão francesa é aquele realizado na sequência do gesto dêitico descrito na figura 64. Logo depois de indicar a presença de Romeu, através de um gesto dêitico (a), Julieta realiza um movimento circular com a parte superior do torso (b). Ela ainda não percebeu que ele está morto. Sua cabeça se inclina para trás, a partir do pescoço, com o rosto voltado para cima, assim como os braços. As mãos têm os dedos contraídos em direção às palmas viradas para dentro. Ao terminar o movimento circular, a cabeça continua inclinada para trás, os braços se mantêm para cima, os dedos das mãos se estendem com as palmas voltadas para cima, o rosto se volta para a plateia e os lábios assumem a configuração aberta em sorriso. O conjunto de elementos do gesto sugere a metáfora conceitual ALEGRIA É PARA CIMA (c). 
a)

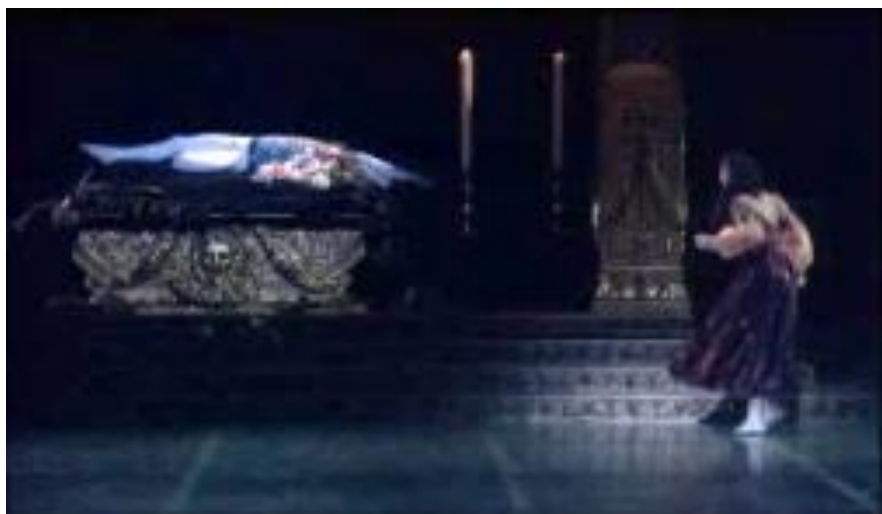

b)

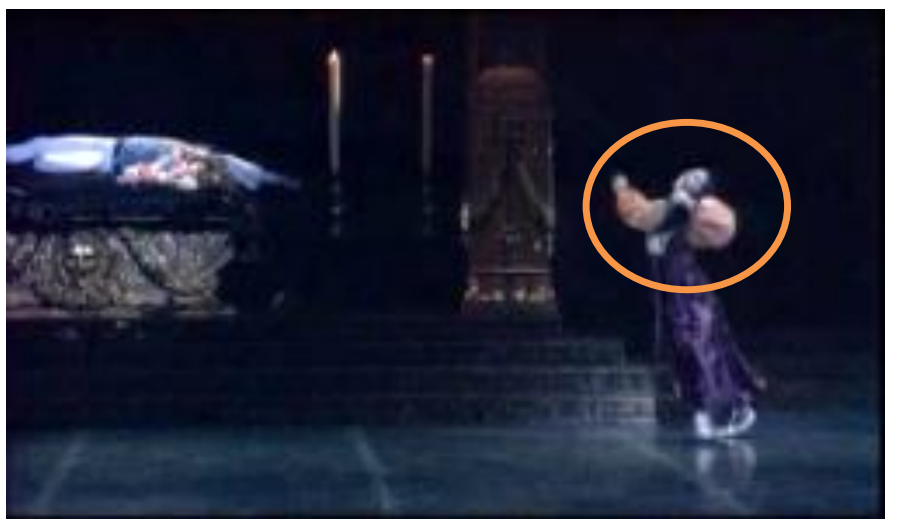

c)

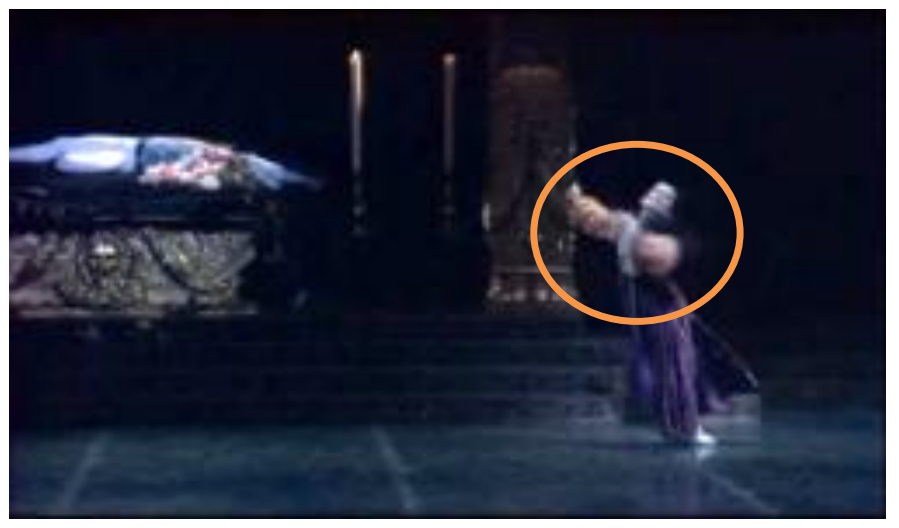

Figura 94. Exemplo de gesto icônico metafórico retirado da cena final na versão francesa, realizado com o torso, a cabeça, os braços e a face.

.......|Videos $\backslash$ Gestos Dissertação\Metafórico 5.wmv

A inclinação da cabeça para trás e a postura dos braços fogem dos padrões estabelecidos para a execução do cambré, que prevê a inclinação da parte superior do tronco para trás sem a inclinação separada da cabeça, ou seja, o movimento é realizado em bloco arqueando-se a coluna dorsal (indicada pela seta laranja), com os ombros, pescoço e cabeça formando um bloco único sem articulação. 


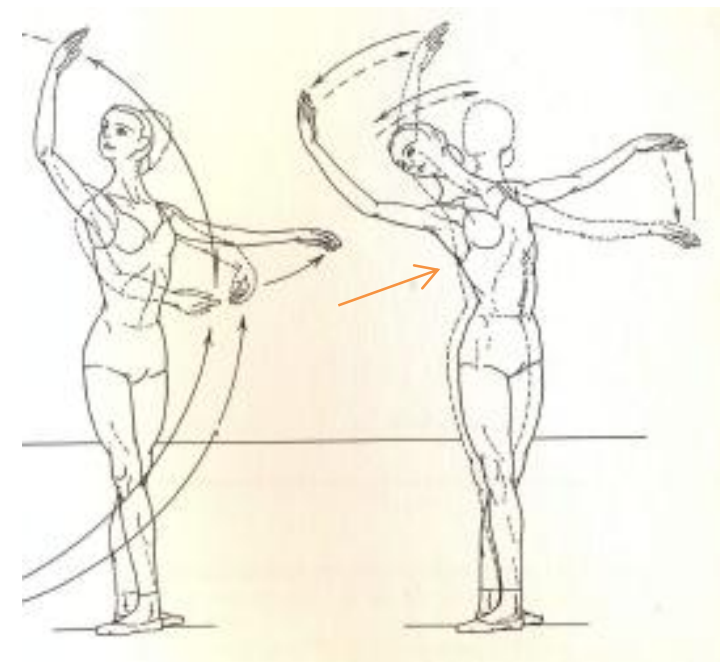

Figura 95. Cambré com braços em terceira posição de braços, retirada de Kirstein, Stuart e Dyer (1952, p. 97).

Os braços podem iniciar o movimento em terceira posição (cf. figura 10) ou passar da segunda (cf. figura 9) à quinta posição (cf. figura 12), sem parada no ponto em que cotovelos e mãos se voltam para cima. Como a postura de cabeça e braços presentes no exemplo do gesto icônico metafórico não correspondem a posições canônicas na técnica clássica, estou considerando que pertençam ao elemento gestual presente na realização do cambré. Novamente é possível perceber como o nível gestual se associa ao nível técnico para compor um signo na coreografia.

Apresento abaixo mais um exemplo de gesto icônico metafórico presente na cena final da versão francesa. Nesse ponto da cena, Julieta, logo após abraçar Romeu, beija-lhe a boca. Ao fazê-lo, Julieta se dá conta de que ele está morto. Em um gesto icônico diagramático, ela coloca sobre seus lábios, abertos e arredondados, sua mão direita aberta, com os dedos estendidos e a palma virada para dentro (a). As sobrancelhas estão levantadas e a testa franzida. O olhar vago acompanha a cabeça que vira para a direita.

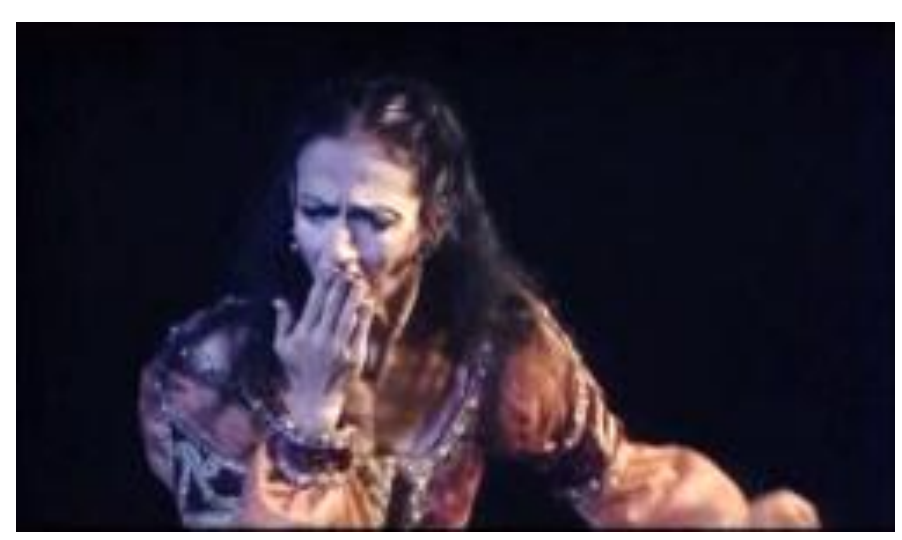

Figura 96. Sequência retirada da cena final na versão francesa, na qual Julieta realiza um gesto icônico diagramático. 
Em seguida, ela baixa a mão, dobrando o pulso em direção ao dorso da mão com dedos e palma espalmados. Ao mesmo tempo, inclina a cabeça e o olhar para baixo para a palma da mão, mantendo a expressão facial anterior (b). O gesto que ela produz conceitualiza a morte de Romeu na mão que foi levada aos lábios. O movimento descendente da cabeça, do olhar e da mão sugerem a metáfora conceitual TRISTEZA É PARA BAIXO.

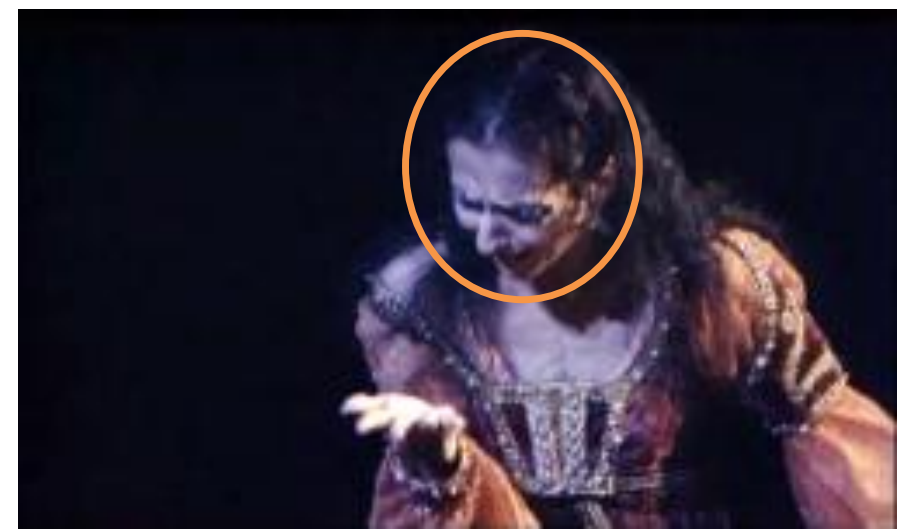

Figura 97. Exemplo de gesto icônico metafórico retirado da cena final na versão francesa.

........ Videos $\backslash$ Gestos Dissertação\Metafórico 6.wmv

Há uma composição de dois tipos de metáforas conceituais presentes nessa sequência gestual. Começando com um gesto icônico diagramático (a mão de Julieta pelos lábios de Romeu), passamos a um gesto icônico metafórico, baseado na metáfora ontológica EMOÇÃO É OBJETO, no qual a morte é vista na palma da mão, por meio de um movimento descendente, interpretado como a metáfora orientacional TRISTEZA É PARA BAIXO. A metáfora ontológica é reforçada por um gesto dêitico, realizado através do olhar de Julieta, direcionado ao objeto conceitualizado na palma de sua mão. Curiosamente, a postura dos dedos, hiperestendidos em direção ao dorso da mão possibilita uma interpretação de não intenção de reter o objeto na mão, ou desejo de se livrar do objeto que está na mão, diferentemente da configuração de mão com palma para cima observada no exemplo da figura 88. Naquele caso, a mão tem uma configuração de suporte do objeto ali conceitualizado.

De maneira geral, as instâncias metafóricas estão baseadas em metáforas orientacionais, que lidam com relações espaciais baseadas na vivência de nossos corpos no espaço. Isso talvez se deva ao aspecto físico da dança, que traz em seu escopo técnico, mas não apenas nele, essa mesma qualidade de orientação corporal no espaço. Há, no entanto, três exemplos de metáforas ontológicas, que se baseiam em nossas 
experiências com objetos e substâncias. Nesses exemplos, reproduzidos nas figuras 88 , 90 e 97, a metáfora tem uma clara base metonímica, corroborando a proposta de Mittelberg e Waugh (2009).

Os gestos metafóricos que acompanham a técnica tendem a ser produzidos no ponto mais focal do movimento técnico. O ponto focal é entendido aqui como o momento em que o movimento assume a postura pela qual o passo é conhecido. $\mathrm{Ou}$ seja, é o ponto máximo de abertura do grand jeté ou da elevação da perna atrás do corpo no arabesque, por exemplo. Assim, os gestos metafóricos são produzidos no ápice do grand jeté (cf. figura 85) e do arabesque (cf. figura 87). No caso da pirueta terminada em degagé derriére (figura 88), o gesto começa no final da pirueta, mas termina junto com o final do degagé. No caso do gesto que acompanha o grand rond de jambe (figura 90), acontece o oposto: os braços produzem o gesto no início do movimento técnico, mas fazem a retração parcial antes do final do rond de jambe. Não é possível dizer que há um padrão para a produção de um gesto metafórico acompanhando a técnica, mas a tendência é que a fase expressiva seja produzida junto com o ponto focal do movimento.

\subsection{Batidas}

As batidas na gestualidade que acompanha a fala têm dupla função, segundo McNeill (1992). A primeira refere-se ao acompanhamento do ritmo da fala. A segunda função é mais pragmática e refere-se ao realce que a batida confere aos constituintes do enunciado com os quais co-ocorre. Por vezes essas funções são concomitantes. Em dança, aparentemente, as duas funções também estão presentes e se verificam pela repetição de movimentos não-convencionais; a primeira função parece subordinar-se à segunda, já que as repetições enfatizam o movimento original. Nas cenas observadas, houve apenas duas ocorrências de batidas.

O primeiro exemplo acontece na cena do balcão, enquanto Romeu se declara a Julieta, dançando uma sequência coreográfica. Antes do final da sequência, Julieta realiza com as mãos um gesto metafórico e respira profundamente três vezes, movimentando a parte superior o torso, seguindo o ritmo musical. A respiração é considerada como batida, pois está sendo realizada de acordo com a música, de modo a preparar a plateia para o final da frase musical, no qual ocorrerá um gesto de Romeu e outro de Julieta. Ela também pode ser considerada um gesto icônico metafórico que mostra uma crescente ansiedade. De acordo com Humphrey (1959), esse gesto poderia 
representar alteração no ritmo respiratório, ligado a reações fisiológicas. A cabeça também se move seguindo o ritmo da música, com movimento das pálpebras, porém esses movimentos não são recorrentes, como no caso do movimento do torso, não configurando assim uma batida. As setas laranja indicam o ponto na base do pescoço da bailarina que se move para dentro no momento da inspiração mais profunda.

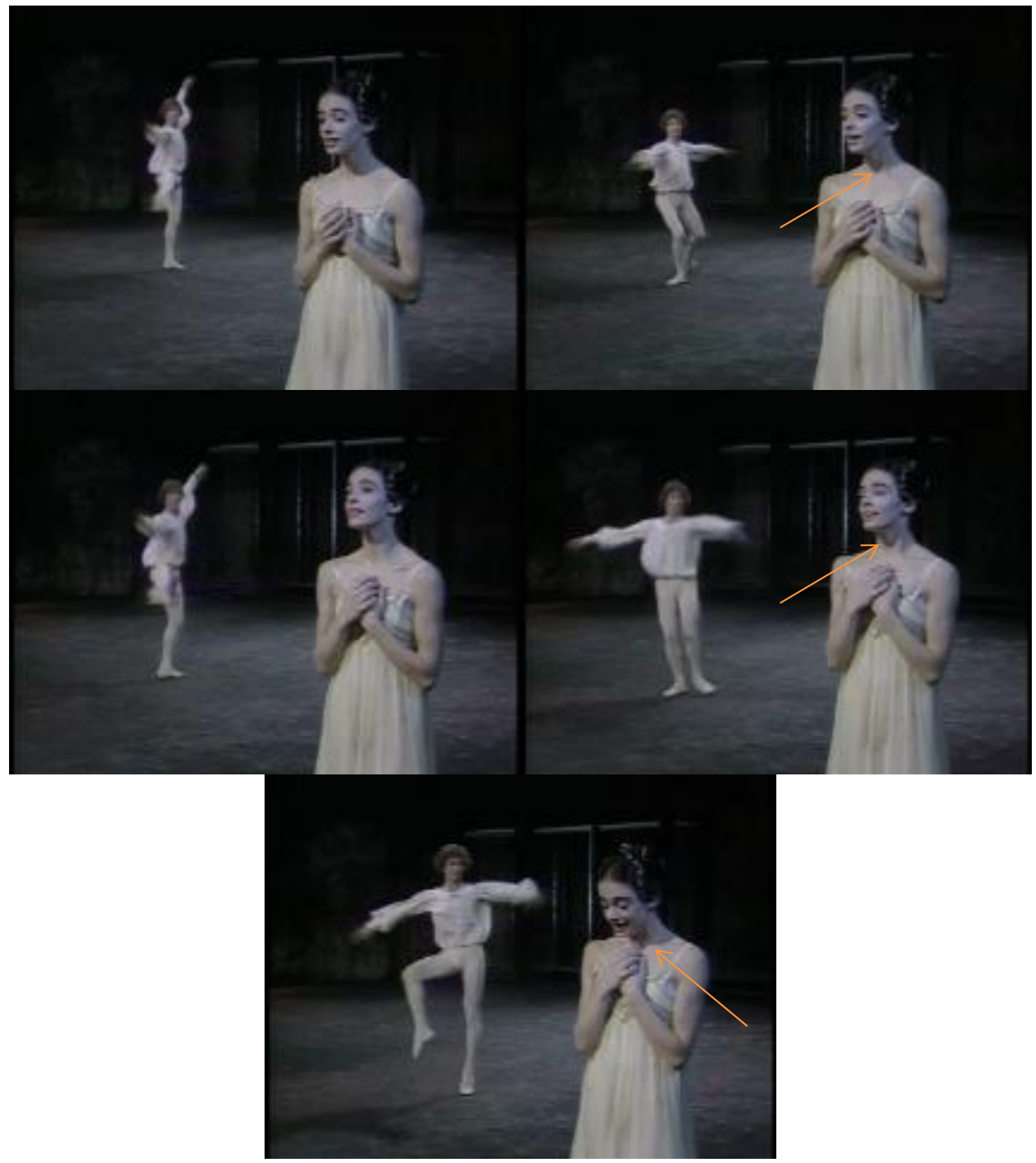

Figura 98. Exemplo de batida na cena do balcão, realizada através da elevação da parte superior do tronco. ........|Videos\Gestos Dissertação\Ex Batida.wmv

Outro exemplo foi observado na cena final, na versão francesa (figura 99). Julieta está sobre a tumba, junto ao corpo de Romeu. Ela se joga para trás, sobre o corpo dele. Seu corpo movimenta-se para frente e para trás, sempre sobre o corpo de Romeu, 
seguindo a frase musical. Esse gesto também pode receber uma interpretação metafórica no sentido de dar uma forma ao desespero. Com relação à Humphrey (1959), o balanço lateral do corpo estaria ligado ao sentimento de luto, caracterizando um gesto emocional. No caso de Hanna (1990), essa poderia ser uma concretização para a interpretação metafórica de desespero. Ao mover o torso para frente, a bailarina flexiona o braço direito. $\mathrm{O}$ braço se estende parcialmente quando a bailarina move o torso para trás. Esse movimento pode ser observado em fotografia pela diferença na distância entre o ombro e a mão da bailarina que repousa sobre o corpo do bailarino, indicada pelo traço laranja.

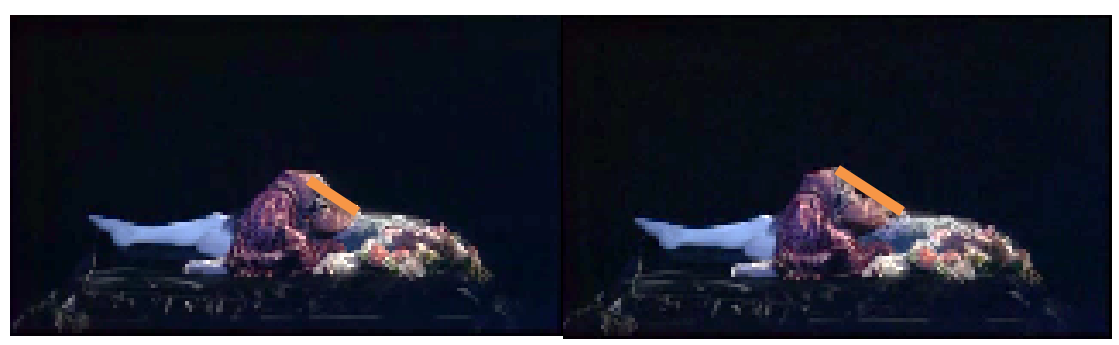

Figura 99. Exemplo de batida na cena final, realizado com o movimento do corpo para frente e para trás. ..1.....|Videos \Gestos Dissertação\Ex Batida 2.wmv

Como as sequências coreográficas estão estabelecidas sobre o escore musical, há a possibilidade de o acompanhamento do ritmo do discurso por meio de batidas ser realizado também através de movimentos pertencentes ao nível técnico. Talvez esse fator explique as raras instâncias de batidas observadas no nível gestual.

\subsection{Coesivos}

Gestos coesivos que acompanham a fala conectam partes tematicamente próximas, mas temporalmente distanciadas no discurso. Eles têm uma função discursiva e não apresentam morfologia própria (McNeill 1992). Foi possível traçar um paralelo entre esse tipo de gesto que acompanha a fala e seu correlato em narrativas dançadas. Encontrei semelhanças gestuais situadas em diferentes pontos da coreografia, como que retomando a linha narrativa depois de uma ou mais sequências coreográficas interpoladas. O tipo de gesto que identifico como coesivo, no caso de Julieta, é também um gesto icônico metafórico realizado com os braços, ao mesmo tempo em que ela faz um gesto dêitico (cf. figura 58). Nos dados relativos a Romeu, a retomada se dá através de um gesto icônico diagramático realizado com o braço e a mão (cf. figuras 76 e 77). 
a)

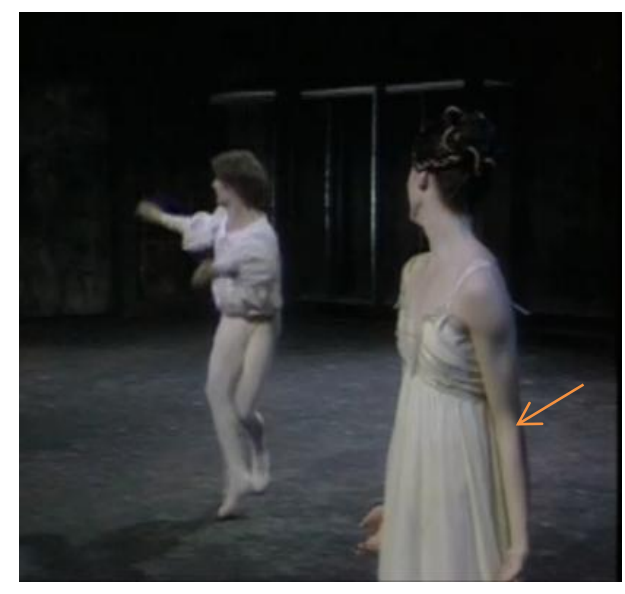

b)

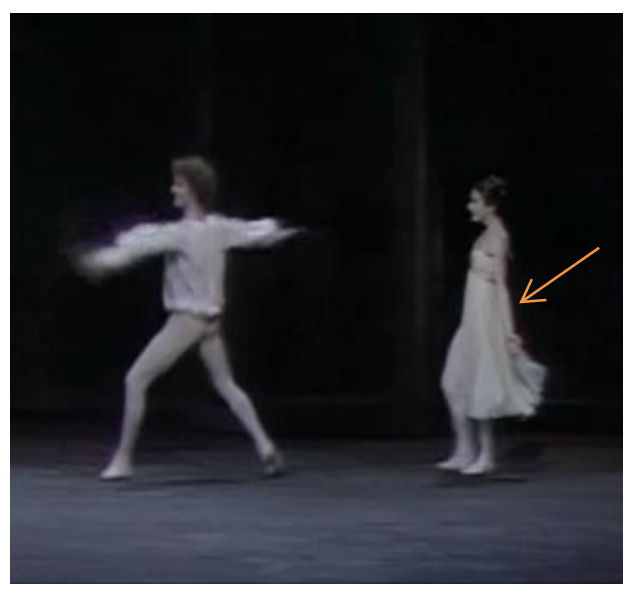

Figura 100. Exemplo de gesto coesivo de Julieta. a)primeira ocorrência; b) segunda ocorrência do gesto de braços.

.......|Videos \Gestos Dissertação\Coesivo 1a.wmv

....... IVideos $\backslash$ Gestos Dissertação\Coesivo 1b.wmv

O gesto (a) de Julieta acontece entre 00:02:43.780 e 00:02:46.650. O gesto (b) ocorre entre 00:03:07.070 e 00:03:08.510. A posição de braços virados para fora e a configuração de mãos, com os dedos abertos e as palmas voltadas para frente, é bastante semelhante nas duas ocasiões, e ambos os gestos acontecem ao final de uma sequência dançada por Romeu. A retomada temática dos gestos coesivos que acompanham a fala se dá através de gestos com morfologia semelhante, realizados simultaneamente com vocábulos associados a um mesmo assunto. A configuração semelhante de braços e mãos nas duas ocorrências acima parece embasar a ideia de que a segunda ocorrência é um exemplo de gesto coesivo. Além disso, o contexto fornece elementos para que os gestos sejam reconhecidos na categoria coesiva. Julieta coloca as mãos cruzadas sobre o peito, em um gesto metafórico, de frente para o público. Ao virar o rosto para olhar Romeu, ela realiza o gesto metafórico com os braços e as mãos, como se estivesse oferecendo a ele o que está em seu peito ${ }^{83}$. Julieta o faz da primeira vez longe de Romeu. Ela repete o gesto metafórico após um gesto metafórico de Romeu (cf. figura 86), aproximando-se dele, propiciando a continuação da ação, que será um beijo (cf. figura 65). É como se ocorresse a retomada e o prosseguimento da ação. Desse modo, além da forma, também a função reforça uma classificação na categoria coesiva.

\footnotetext{
${ }^{83}$ Essa extensão metafórica é possível graças à metáfora EMOÇÃO É OBJETO. No caso, Julieta faz um gesto que se assemelha ao gesto de entregar algo a alguém. A diferença reside na abstração do gesto, feito ao lado do corpo da intérprete e não à frente dele, como seria esperado. Outra possibilidade é Julieta estar se entregando a Romeu. Nesse caso, a metáfora conceitual seria PESSOA É OBJETO, na qual Julieta se torna um objeto a ser entregue a Romeu. Em ambos os casos, as metáforas são ontológicas, permitindo a manipulação de entidades ou emoções do mesmo modo como experienciamos objetos no mundo, nesse caso específico, como algo que pode ser oferecido a outra pessoa.
} 

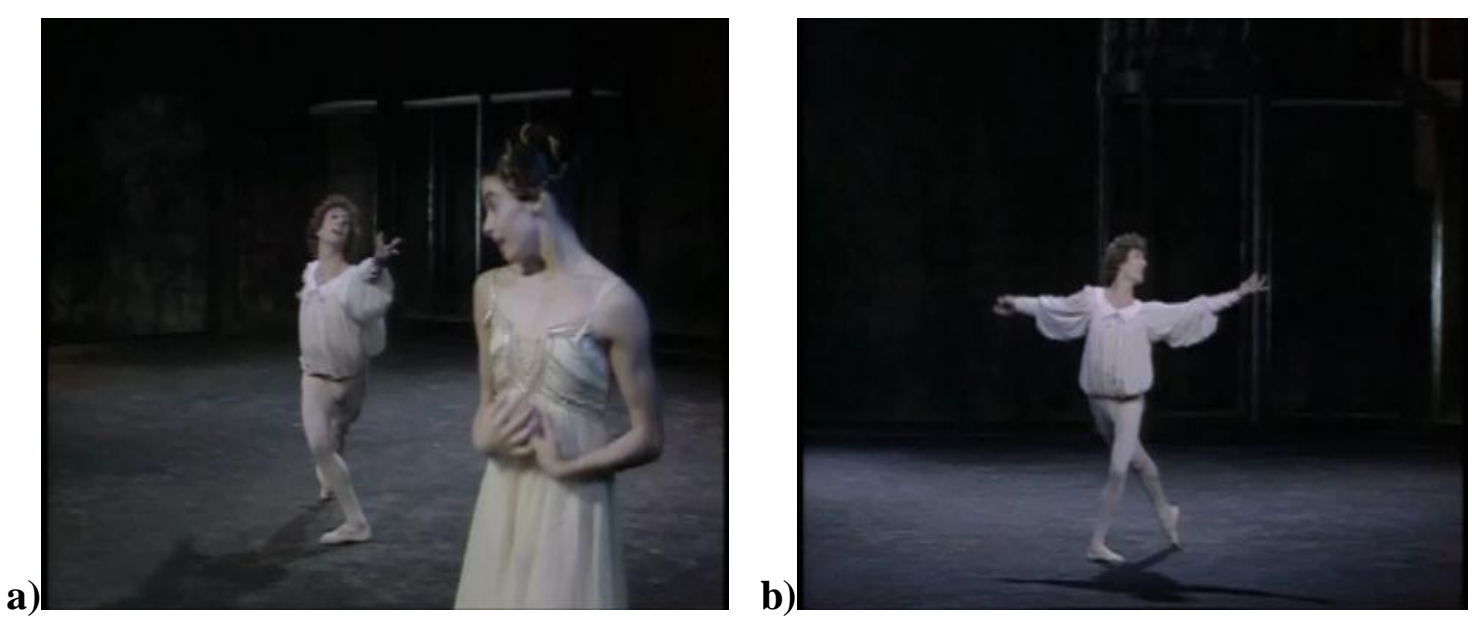

Figura 101. Exemplo de gesto coesivo de Romeu. a) primeira ocorrência; b) segunda ocorrência de gesto diagramático.

........|Videos $\backslash$ Gestos Dissertação\Coesivo 2a.wmv

....... Videos $\backslash$ Gestos Dissertação\Coesivo 2b.wmv

O primeiro gesto de Romeu, (a), acontece no espaço de tempo entre 00:02:44.770 e 00:02:46.530. O segundo, (b), tem lugar entre 00:02:56.960 e 00:02:58.190. A posição de braço estendido e mãos com dedos abertos e palma voltada para cima é bastante semelhante nas duas ocasiões, havendo diferença apenas na perna de apoio, com inversão da direita pela esquerda, já que nas duas ocasiões o bailarino executa uma quarta allongé, e a configuração de ombros (inclinados) e direção do olhar (em direção ao interlocutor) são as mesmas. O espaço de tempo entre as ocorrências e suas semelhanças morfológicas são traços que correspondem a um gesto coesivo, de acordo com a definição de McNeill. Ligada a isso está a função do gesto diagramático, interpretado como um possível pedido para aproximação. A primeira ocorrência do gesto tem como repercussão o gesto de oferecimento de Julieta descrito acima (figura 100). A segunda ocorrência provoca a aproximação de Julieta. É como se o pedido fosse retomado após a sequência coreográfica. Esse fator também reforça a categorização do gesto como coesivo.

\subsection{Algumas considerações}

O modo como os gestos interagem com o movimento técnico varia não apenas de acordo com a categoria gestual, mas também em função do passo técnico. Como já mencionado, um passo que requeira uma báscula da cintura pélvica pode provocar uma desaceleração do gesto. Também pode acontecer de o gesto ocorrer no ápice do movimento técnico. De maneira geral, sugiro que o gesto apresente uma relação 
intuitiva com o passo técnico. Isso quer dizer que o gesto tende a ser coordenado com o movimento técnico em função do grau de dificuldade na execução de um determinado passo. Essa dificuldade pode se dar em função do grau de complexidade na execução do próprio passo, ou de sua inserção na sequência coreográfica, quando um passo anterior ou posterior pode tornar a execução do movimento técnico mais demandante em termos de coordenação de movimento, exigindo maior atenção por parte do bailarino.

Outro ponto ressaltado pela análise é a maneira pela qual o gesto é construído e o impacto disso no sentido atribuído ao gesto. Retomando os gestos presentes no abraço da cena final nas duas versões, podemos analisar o impacto que a construção dos diferentes signos causa. As diferentes configurações faciais, uma voltada para baixo expressando tristeza e outra voltada para cima expressando alegria, são o componente mais evidente para as diferentes interpretações que um mesmo gesto pode ter. Essas expressões são a forma encontrada para conceitos abstratos, tornando-se gestos icônicos metafóricos associados ora a um gesto icônico imagético, ora a um gesto icônico diagramático, produzidos com o corpo. A associação da metáfora com a imagem cria um signo composto, adaptando a proposta de Clark (1996, p. 185) para signos $\operatorname{compostos}^{84}$. No entanto, também a diferença no posicionamento do corpo de Romeu com relação ao corpo de Julieta torna-se relevante para a interpretação dos signos: na versão inglesa, o rosto de Romeu está longe do de Julieta, e ele tem a cabeça inclinada para baixo; na outra versão, o rosto de Romeu encosta no de Julieta e sua cabeça está voltada para cima. A escolha da perspectiva a partir da qual o gesto é executado tornase, assim, um componente reiterador da intenção do coreógrafo: uma perspectiva, a inglesa, evidencia o sentimento presente na expressão facial, com a posição frontal de Julieta e a posição posterior de Romeu, enquanto a outra, a francesa, minimiza elementos que possam contradizer o sentimento expresso pela personagem feminina, como a opção pela posição lateral de ambos os bailarinos, de modo a não ressaltar a

\footnotetext{
${ }^{84}$ Clark (1996) propõe os seguintes modos de sinalização: $(i)$ indicação - realizada por apontamento -, (ii) descrição - quando símbolos são usados para descrever algo -; e (iii) demonstração - realizada pela representação de aspectos de um objeto ou ação. Um signo composto é formado através do uso simultâneo dos três métodos de sinalização. Por exemplo, quando ocorre o uso de símbolos (componentes linguísticos usados para a descrição) concomitante com a localização de entidades (indicação) e com a formatação de um conceito (demonstração), como na sentença: Ele sempre me enlouquece, produzida com um apontamento de cabeça em direção a um referente masculino e um gesto feito com ambas as mãos colocadas nas laterais da cabeça, à altura dos olhos, com os dedos estendidos e as palmas viradas para dentro.
} 
posição inerte dos braços de Romeu. Ocorre, dessa forma, uma composição de diferentes gestos construídos e apreendidos simultaneamente, como ilustrado abaixo.

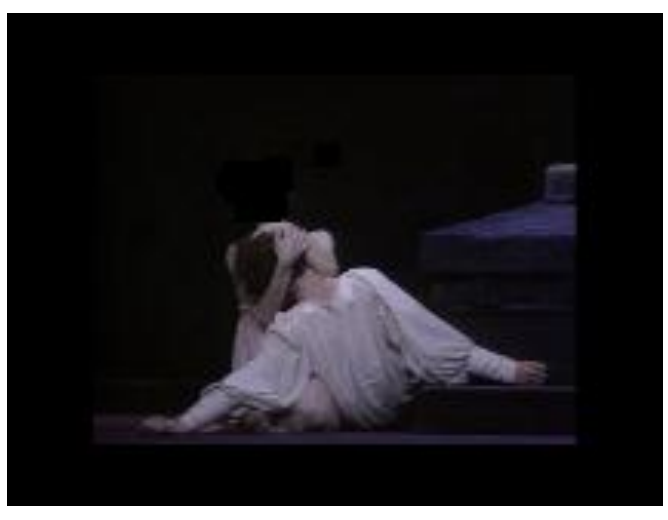

icônico diagramático

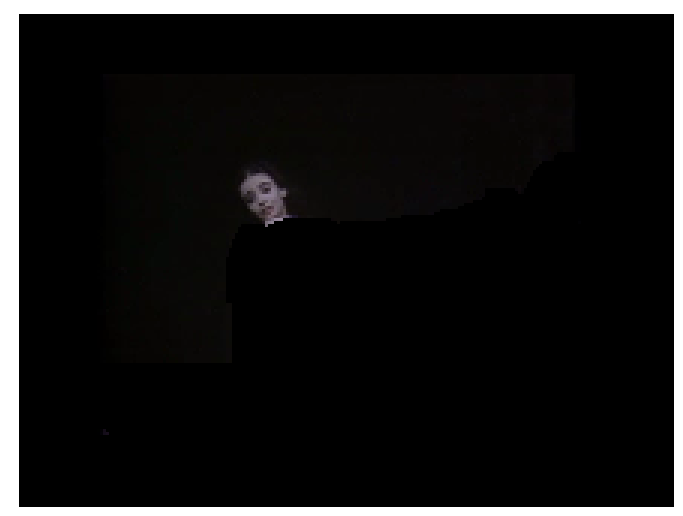

icônico metafórico

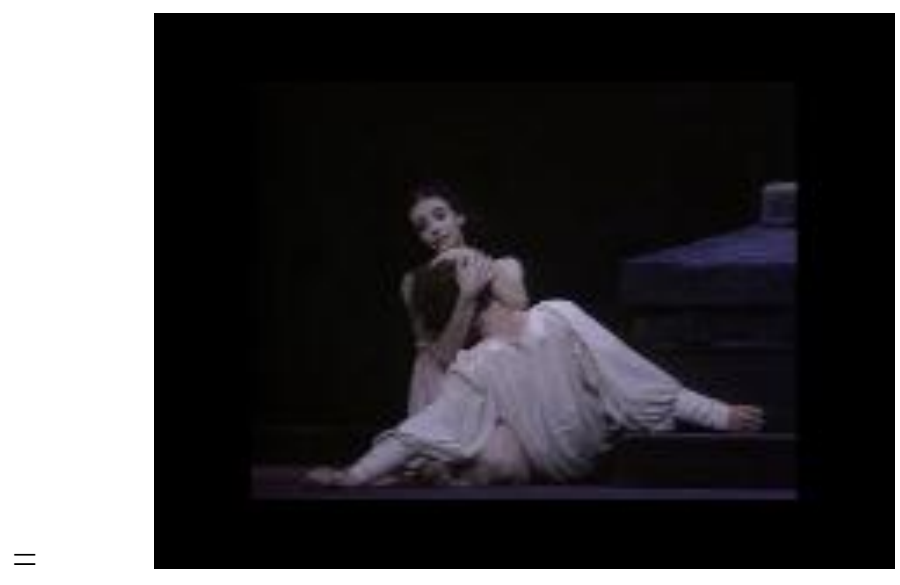

Figura 102. Composição de gesto icônico diagramático com gesto icônico metafórico.

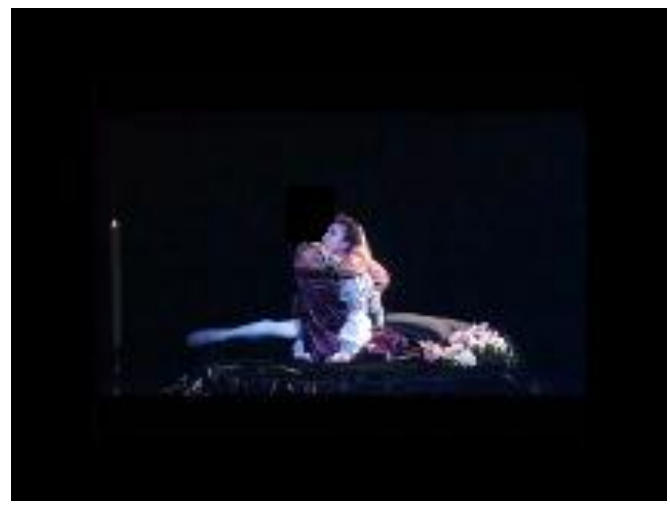

icônico imagético

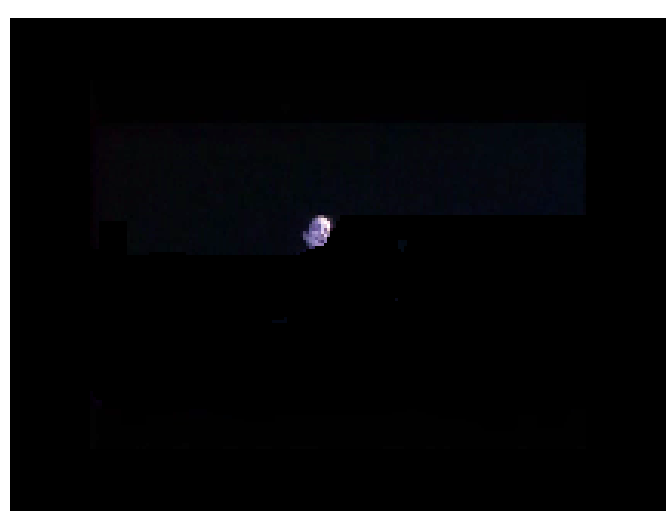

icônico metafórico 


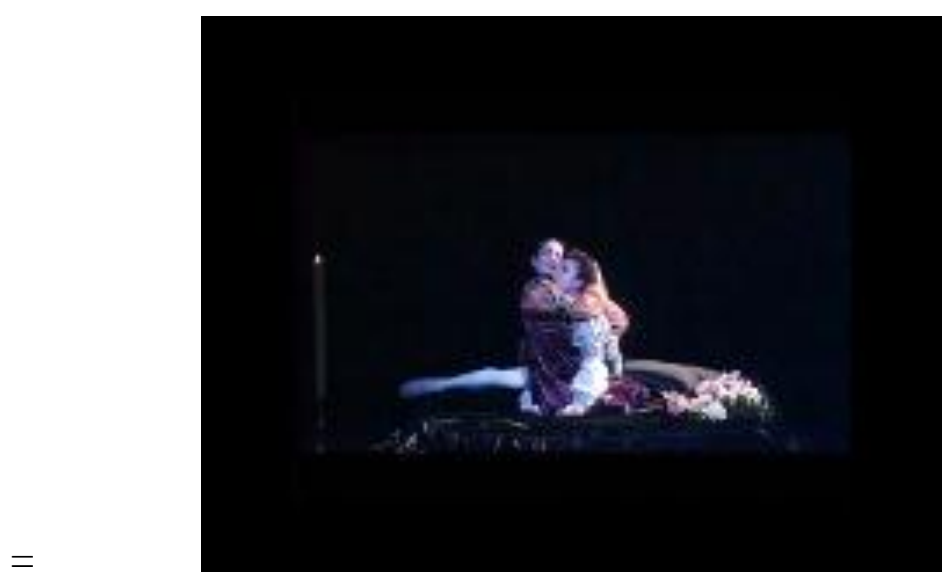

Figura 103. Composição de gesto icônico imagético com gesto icônico metafórico.

Além disso, as pantomimas são ricas em gestos. Gestos icônicos imagéticos, dêiticos, icônicos diagramáticos, icônicos metafóricos e batidas puderam ser observados nas pantomimas. Fica evidenciada a necessidade de analisar também o gesto na pantomima, para que se possa apreender toda a riqueza semiótica aí presente. A literatura sobre a dança costuma usar a denominação pantomima de maneira generalizante, o que faz com que muitas camadas de significação e a possibilidade de investigação da conceitualização sejam deixadas de lado.

Os dados apresentam evidências que suportam a proposta de estrutura tríplice para o discurso dançado. Encontrei exemplos de gestos produzidos em conjunto com movimentos pertencentes à técnica de dança clássica e em pantomima. Dentre as categorias de gestos, a dos icônicos diagramáticos, icônicos metafóricos e coesivos foram as que se mostraram mais produtivas quando associadas à técnica. As categorias dos icônicos imagéticos e batidas mostraram-se mais produtivas na produção de pantomimas. Minha hipótese para tal diferença é a de que a pantomima, por reproduzir ações cotidianas no mundo, propicia a produção de gestos icônicos imagéticos, não exclusivamente, já que há exemplos de gestos dêiticos, icônicos diagramáticos e icônicos metafóricos sendo produzidos nesse contexto. Essas representações estão mais próximas dos protótipos estabelecidos para as ações, enquanto que os passos técnicos afastam-se desses protótipos.

Os dados corroboram a diversidade de dimensões semióticas envolvidas na produção gestual e demonstra a já mencionada complexidade envolvida no processo de categorização, apontado por Bressem (2008). A escolha da dimensão mais saliente é, de fato, dependente do contexto, ainda que essa palavra abra uma discussão acirrada, por 
compreender várias dimensões (física, espacial, temporal, narrativa, etc). Minha proposta de classificação fica, portanto, aberta à discussão. 


\section{Considerações finais}

A dança teatral traduz processos cognitivos atuantes na construção de significado, inclusive através da gestualidade nela presente. Construindo o discurso dançado junto com a técnica e a paraquinese, ela torna a narrativa legível para a plateia, reproduzindo os mesmos processos presentes nos gestos que acompanha a fala.

Como já mencionado na evolução do balé, excertos pantomímicos contribuem com grande parte do significado da dança, já que a técnica acaba por ter uma semântica mais abstrata. Por exemplo, um arabesque ouverte pode ser produzido com a intenção de chamar um parceiro ou uma parceira, por exemplo, ou de atacar um companheiro ou companheira de cena. Ele tem sempre um sentido de elevação e demonstração de equilíbrio, que pode ser um chamariz no caso de uma cena amorosa (interpretação possível pela demonstração de Brown et al 2005 mencionada no capítulo 1), ou de força ou estabilidade, no caso de uma cena de confronto (tornando-se um sinal de qualidade do indivíduo para seu oponente). Os gestos que acompanham a técnica e que estão presentes na pantomima ajudam a contextualizar as sequências coreográficas. As escolhas do repertório gestual, em conjunto com as escolhas de passos e do uso da paraquinese, definem, também, a conceitualização escolhida pelo coreógrafo ou pelo intérprete, colocando em evidência o ponto de vista adotado para a criação da obra. $\mathrm{O}$ peso de cada parte dessa estrutura tripartite na composição da significação é algo a ser estudado em um futuro trabalho.

Com base na análise apresentada, é possível sustentar a proposta de uma estrutura tríplice para o discurso dançado. Praticamente em todas as categorias apresentadas houve a interação entre gesto e técnica, na qual partes do corpo executam um passo canônico da dança clássica enquanto outras partes gesticulam. Apesar da execução simultânea de um movimento técnico e de um elemento gestual, o gesto parece contribuir para que a linha narrativa não seja completamente descontinuada pela execução técnica no decorrer da coreografia. O gesto contribui também para que os passos ganhem poder comunicativo, através de contornos mais concretos. Nesse ponto, acaba ocorrendo uma aproximação com a questão do valor semântico das palavras na língua. As palavras ganham sentido completo quando inseridas em um discurso. No caso dos passos de dança, o sentido também depende do discurso para poder se atualizar. Os gestos parecem contribuir grandemente para essa atualização na dança, 
assim como contribuem para o discurso verbal. Se tomarmos dois exemplos de arabesque presentes nos dados (figuras 87 e 90, reproduzidas abaixo na figura 104), podemos perceber como um mesmo passo pode ser transformado pelo gesto: na figura 87 (a), ele é produzido com um gesto metafórico e ganha um valor correspondente à metáfora concretizada no gesto (ALEGRIA É PARA CIMA), ao passo que, na figura 90 (b), os braços assumem uma posição canônica no arabesque, tornando-o um objeto de apreciação estética, por sua forma.
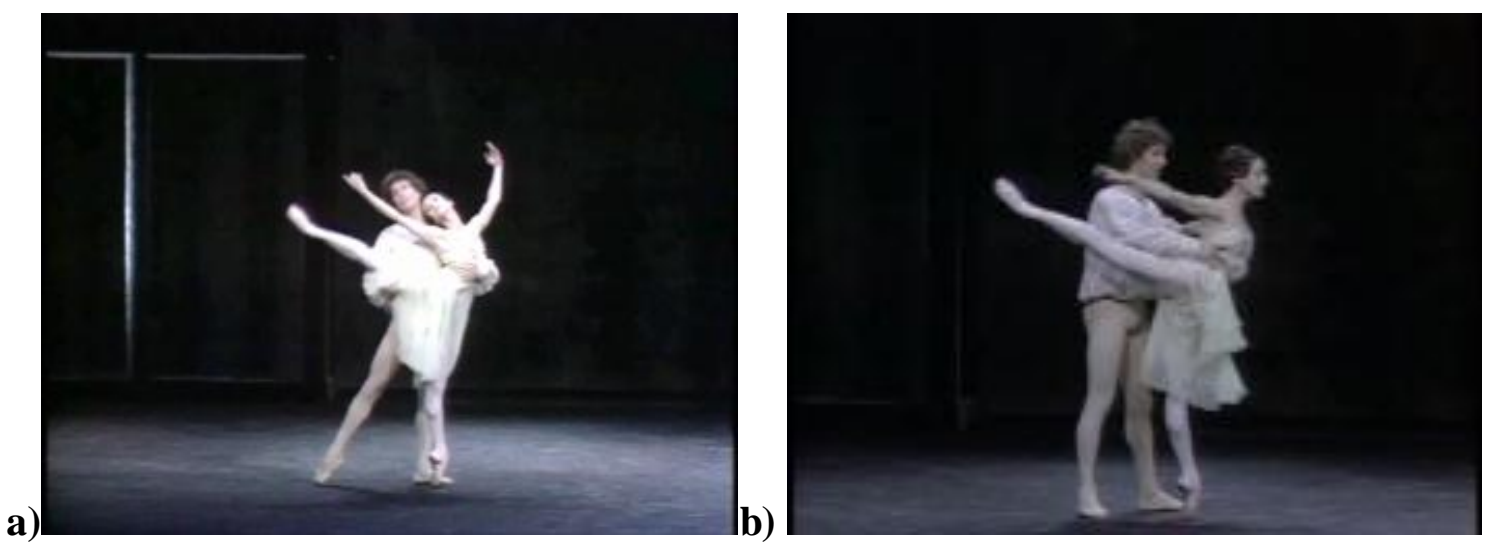

Figura 104. Exemplos de arabesques, retirados das figuras 87 e 90 .

Várias instâncias foram encontradas para as categorias gestuais propostas, algumas com maior riqueza de exemplos que outras. Aparentemente, as categorias de gestos coesivos e batidas, que nos gestos que acompanham a fala estão mais ligadas ao caráter discursivo, foram aquelas com menos exemplos presentes no discurso dançado. Isso talvez se deva à natureza do discurso dançado e uma investigação mais específica se faça necessária para a compreensão dos processos coesivos e as estratégias para realçar a relevância de movimentos em dança.

A análise de gestos em contexto não linguístico verificou que processos conceituais presentes em contextos linguísticos também estão presentes em ausência de língua, o que parece reforçar a relação entre gesto e pensamento proposta por McNeill (1992, 2000, 2005). Também a proposta de Johnson (2007), de que, através do corpo, é possível construir e compreender significados, fica reforçada pela observação dos signos construídos com o corpo dos bailarinos, em si mesmos e entre eles, com relação ao espaço cênico e em sua relação com a plateia.

Nas narrativas analisadas foi possível observar os três níveis propostos para o discurso dançado e exemplos para as categorias gestuais propostas. Para embasar as 
propostas aqui apresentadas, seria recomendável que fosse feita uma análise da gestualidade presente em coreografias sem uma narrativa explícita, algo a ser explorado em um futuro trabalho. Outras perspectivas ainda se abrem para a continuação deste trabalho. Além da verificação da pertinência da estrutura tripartite e da relação de peso dos níveis na composição coreográfica, há, ainda, a possibilidade de melhoria do sistema de transcrição através da incorporação de novas trilhas, não apenas como sugerido no capítulo 2, mas também no sentido de melhor adequar o vocabulário controlado e a anotação de articuladores, como no caso das mãos.

A relação entre as frases coreográficas, as fases gestuais e as frases musicais é outro tópico que pode trazer muitas contribuições para o entendimento do processo de composição do discurso dançado. Depois de estabelecida a pertinência da estrutura tríplice no discurso dançado em diferentes técnicas de dança, é possível quantificar as categorias gestuais para poder inferir suas relações com o nível técnico.

A paraquinese também deve ser estudada de forma mais aprofundada para o entendimento da contribuição de cada um dos níveis para a construção da significação em dança. Enfim, um melhor entendimento desses aspectos poderá abrir, ainda, novas perspectivas para o ensino da dança, em geral, e da composição coreográfica, mais especificamente. Há, ainda, a possibilidade de estudos comparativos da gestualidade que acompanha a dança com aquela que acompanha a fala e aquela presente em línguas sinalizadas, visando a contribuir para uma melhor compreensão dos processos envolvidos na construção de significação de maneira mais abrangente. 


\section{Bibliografia}

Adshead, J. (1988). Dance Analysis:Theory and practice. London: Dance Books Ltd.

Au, S. (1988). Ballet \& Modern Dance. London: Thames and Hudson Ltd.

Balanchine, G. \& Mason, F. (1954 [1989]). 101 Stories of the Great Ballets. New York: Anchor Books.

Benveniste, E. (1966). Problemas de Linguística geral I. Campinas: Pontes Editores.

Brandt, P.A. (2009).The sign cascade. A basic format of semiotic apperception. In: Language in Life, and a Life in Language. Jacob Mey - a Festschrift. Studies in Pragmatics 6, Bingly UK: Emerald.

Brown, W. et al. (2005). Dance reveals symmetry especially in young men. Nature, vol. 438, pp. 1148-1150.

Calbris, G. (2008). From left to right : Coverbal gestures and their symbolic use of space. In A. Cienki \& C. Müller (Eds.), Metaphor and Gesture2 (pp. 27-53). Amsterdam/Philadelphia: John Benjamins Publishing Company.

Clark, H.H. (1996). Using Language. Cambridge: Cambridge University Press.

Corbin, A., Courtine, J. \& Vigarello, G. (2009). História do Corpo: As mutações do Olhar. O Século XX. Petrópolis: Editora Vozes Ltda.

Cohen, S.J. (1974 [1992]). Dance as a Theatre Art. Princeton Book Company.

Danaher, D. (1998) Peirce's semiotic and conceptual metaphor theory. In Semiotica, $\operatorname{vol.2}(119-1 / 2)$, pp.171-207, 1998.

Evola, V. (2010). A multimodal analysis of individuals' beliefs and metaphors in words, gestures and drawings. In F. Perrill, V. Tobin, \& M. Turner (Eds.), Meaning, Form, and Body2 (pp. 41-60). Standford, CA: Center for the Study of Language and Information. 
Farias, P. (2003) Imagens, diagramas e metáforas: uma contribuição da semiótica para o design da informação. In: Congresso Internacional de Design da Informação, 2003, Recife. Anais do Congresso Internacional de Design da Informação. Recife : SBDI - Sociedade Brasileira de Design da Informação, 2003. v. 1. p. 1-11.

Farias, P. e Queiróz, J. (2006). Images, diagrams, and metaphors: Hypoicons in the contexto of Peirce's sixty-six-fold classification of signs. Semiotica $162-1 / 4$ (2006), 287-307.

Farnell, B. (1994). Ethno-Graphics and the Moving Body. Man, New Series, vol. 29, no.4, pp. 929-974.

Fauconnier, G. e Turner, M. (2002). The way we think: conceptual blending and the mind's hidden complexities. New York: Basic Books.

Foster, S. L. (1996). Coreography and narrative: ballet's staging of story and desire. Bloomington: Indiana University Press.

Goldin-Meadow,S. (2003). Hearing gestures: how our hands help us think. Cambridge, MA: The Belknap Press of Harvard University Press.

Goodwin, C. (2000). Practices of Seeing, Visual Analysis: An Ethnomethodological Appraoch. In Handbook of Visual Analysis, Theo van Leewen and Carey Jewitt (ed.). London: Sage, pp.157-82.

Goodwin, C. (2003). The body in action. In J. Coupland \& R. Gwyn (Eds.), Discourse, The Body, and Identity (pp. 19-49). New York: Palgrave/Macmillan.

Greimas, A. (1983). Du Sens II. Paris, Seuil.

Hanna, J.L. (1979 [1987]). To Dance is Human: A Theory of Nonverbal Communication. Austin: University of Texas Press.

Hanna, J.L. (1983). The Performer-Audience Connection. Austin: University of Texas Press. 
Hoetjes, M., Khramer, E., Swerts, M. (2012). Do repeated references result in sign reduction? Obtido

em http://mindmodeling.org/cogsci2012/papers/0091/paper0091.pdf

Humphrey, D. (1959 [1987]). The Art of Making Dances. New Jersey: Princeton Book Company.

Hutchins, E. (2006). Imagining the cognitivie life of things. Presented at the symposium: "The Cognitive Life of Things: Recasting the boundaries of Mind" organized by Colin Renfrew and Lambros Malafouris at the McDonald Institute for Archaeological Research, Cambridge University, UK 7-9 April, 2006. The McDonald Institute for Archaeological Research, Cambridge University, UK.

Jakobson, R. (1969). “A Linguagem Comum Dos Linguistas e Dos Antropólogos.” In Linguística e Comunicação, Roman Jakobson. São Paulo: Cultrix, p. 17-18.

Johnson, M. (2007). The Meaning of the Body: Aesthetics of Human Understanding. Chicago: The University of Chicago Press.

Kaepler, A. (1972). Method and Theory in Analyzing Dance Structure with an Analysis of Togan Dance. Ethnomusicolog, vol.16, no. 2, pp. 173-217.

Kendon, A. (1980). Gesticulation and speech: Two aspects of the process of utterance. In M. R. Key (Ed.), Nonverbal communication and language (pp. 207-227). The Hague: Mouton de Gruyter.

Kendon, A. (2000). Language and gesture: Unity or duality? In: D.McNeill (Ed.), Language and Gesture (pp. 47-63). Cambridge: Cambridge University Press.

Kendon, A. (2004). Gesture: Visible Action as Utterance. Cambridge: Cambridge University Press.

Kirstein, L. (1970). Movement \& Metaphor: Four Centuries of Ballet. New York: Praeger Publishers, Inc.

Kirstein, L., Stuart, M., Dyer, C. (1952). The Classic Ballet: basic technique and terminology. New York: Alfred A. Knopf. 
Kita, S., Gijn, I. V., \& Hulst, H. V. D. (1998). Movement Phases in Signs and CoSpeech Gestures, and their Transcription by Human Coders. In I. Wachsmuth \& M. Fröhlich (Eds.), Gesture and sign language in human-computer interaction: Proceedings, International Gesture Workshop, Bielefeld, Germany, September 1997 (Vol. 1371, pp. 23-35). London: Springer-Verlag.

Kövecses, Z. (2002). Metaphor:A Practical Introduction. Oxford/New York: Oxford University Press.

Laban, R. (1978 [1971]). Domínio do Movimento. São Paulo: Summus Editorial.

Lakoff, G. e Johnson, M. (1980). Metaphors We Live By. Chicago: University of Chicago Press.

Lakoff, G. (1987). Women, Fire, and Dangerous Things: What categories Reveal About the Mind. Chicago: University of Chicago Press.

Lawson, J. (1979). The Principles of Classical Dance. New York: Alfred A. Knopf, Inc.

LeBaron, C., \& Streeck, J. (2000). Gestures, knowledge, and the world. In D. McNeill (Ed.), Language and Gesture2 (pp. 118-138). Cambridge: Cambridge University Press.

Leite, T.A. (2008). A segmentação da língua de sinais brasileira (libras): Um estudo linguístico descritivo a partir da conversação espontânea entre surdos. Tese de doutorado. São Paulo: Universidade de São Paulo.

Liddell, S. (2000). Blended spaces and deixis in signed language discourse. Cognitive Linguistics 9: 283-314.

Liddell, S. (2003). Grammar, Gesture, and Meaning in American Sign Language. Cambridge: Cambridge University Press.

Liddell, S. e Metzger, M. (1998). Gesture in sign language discourse. In Journal of Pragmatics 30 (1998), pp. 657-697. Elsevier Science B.V. 
Louis, Luis. Mímica e pantomima. In Mímica \& Teatro Físico. http://www.cialuislouis.com.br/tf-pantomima.htm

McCleary, L. E., \& Viotti, E. D. C. (2010). Sign-Gesture Symbiosis in Brazilian Sign Language Narrative. In F. Parrill, V. Tobin, \& M. Turner (Eds.), Meaning, Form, and Body. (pp. 181-201). Chicago, IL: CSLI Publications, University of Chicago Press.Retrieved from http://papers.ssrn.com/sol3/papers.cfm?abstract_id=1617208.

McCleary, L.E., Viotti, E., Leite, T.A. (2010). Descrição das línguas sinalizadas: a questão da transcrição de dados. In: Alfa, São Paulo, 54 (1): 265-289, 2010.

McNeill, D. (1992). Hand and Mind: What gestures reveal about thought. Chicago and London: University of Chicago Press.

McNeill, D. (ed.) (2000). Language and gesture. Cambridge: Cambridge University Press.

McNeill, D. (2005). Gesture and Thought. Chicago: University of Chicago Press.

Mittelberg, I. (2006). Metaphor and metonymy in language and gesture: Discourse evidence for multimodal models of grammar. Tese de doutorado. Ithaca, NY: Cornell University. Published online. Ann Arbor, MI: UMI.

Mittelberg, I., \& Waugh, L. R. (2009). Metonymy first, metaphor second: A cognitivesemiotic approach to multimodal figures of thought in co-speech gesture. In C. J. Forceville \& E. Urios-Aparisi (Eds.), Multimodal Metaphor (pp. 329-356). Berlin/New York: Mouton de Gruyter.

Moreira, R.L.(2007). Uma descrição da dêixis de pessoa na língua de sinais brasileira: pronomes pessoais e verbos indicadores. Dissertação de mestrado. São Paulo: Universidade de São Paulo.

Müller, C. (2004). Forms and Uses of the Palm Up Open Hand: A case of gesture family? in: C. Müller \& R. Posner (Eds.) The semantics and pragmatics of everyday gestures. Berlin: Weidler Verlag. 
Müller, C. e Cienki, A. (ed.) (2008). Metaphor and gesture. Gesture Studies 3. Amsterdam/Philadelphia: John Benjamins Publishing Company.

Noland, C. (2009). Agency and Embodiement: Performing Gestures/Producing Culture. Cambridge: Harvard University Press.

Pappacena, F. (2009). La Danza Classica:Le origini. Roma: Editori Laterza.

Peirce, C. S. (1992). Trichotomic. [1888]. In N. Houser \& C. J. W. Kloesel (Eds.), The Essential Peirce: Selected Philosophical Writings, Volume 1 (pp. 280-284). Bloomington, IN: Indiana University Press.

Peirce, C. S. (1998). What is a sign? [1894]. The Essential Peirce: Selected Philosophical Writings, Volume 2 (pp. 4-10). Bloomington, IN: Indiana University Press.

Peirce, C. S. (1998). Three trichotomies. (Seleção de: Nomenclature and divisions of triadic relations, as far as they are determined [1903]). The Essential Peirce: Selected Philosophical Writings, Volume 2 (pp. 291-292). Bloomington, IN: Indiana University Press.

Peirce, C.S. (2010). Semiótica. Trad. José Teixeira Coelho Neto. São Paulo: Perspectiva, 2010.

Petrilli, S. (2010). Image and primary iconism: Peirce and Husserl. In Semiotica 181, $1 / 4$ (pp. 263-274). Berlin/New York: Walter de Gruyter GmgH \& Co.

Pichler, D.C., Hochgesang, J.A., Lillo-Martin, D., e Quadros, R.M. (2010). Conventions for sign and speech transcription of child bimodal bilingual corpora in ELAN. LIA.2010; 1 (1): 11-40. NIH Public Acess Author Manuscript.

Poyatos, F. (2002). Language-paralanguage-kinesics: The basic triple structure of human communication. Nonverbal communication across disciplines. Vol. 1: Culture, sensory interaction, speech, conversation (pp. 103-132). Amsterdam/Philadelphia: John Benjamins. 
Quinto-Pozos, D. (2007). Can constructed actions be considered obligatory? In Lingua 117 (2007) 1285 1314, pp. 1285-1314. Elsevier B.V. Versão eletrônica disponível no sítio www.sciencedirect.com

Shakespeare, W. (2006). Tragédias e comédias sombrias: obras completas (Teatro completo, volume 1). Tradução Barbara Heliodora. Rio de Janeiro: Nova Aguilar.

Streeck, J. (2009). Hands. Gesturecraft: The manu-facture of meaning (pp. 39-58). Amsterdam/Philadelphia: John Benjamins.

Trotta, M. (2004). O discurso da dança: uma perspectiva semiótica. Dissertação de mestrado. Universidade de São Paulo, 2004.

Wilcox, S. (2004). Gesture and Language: Cross-linguistic and historical data from signed languages. In Gesture 4:1 (2004) (pp.43-73). Amsterdam/Philadelphia: Johns Benjamin

Williams, D. (1977). The Arms and Hands, with Special Reference to an Anglo-Saxon Sign System. Semiotica 21:1/2, pp. 23-73.

Williams, D. (1991). Anthropology and the Dance: Ten Lectures. Urbana and Chicago: University of Illinois Press.

Williams, R. F. (2008). Gesture as a conceptual mapping tool. In A. Cienki \& C. Müller (Eds.), Metaphor and Gesture (pp. 55-92). Amsterdam/Philadelphia: John Benjamins. 